UNIVERSIDADE DE SÃO PAULO

FACULDADE DE FILOSOFIA, LETRAS E CIÊNCIAS HUMANAS

DEPARTAMENTO DE LINGUÍSTICA

PROGRAMA DE PÓS-GRADUAÇÃO EM SEMIÓTICA E

LINGUÍSTICA GERAL

MARA JANE SOUSA MAIA

Tecendo o estético e o sensível através do bordado na literatura infantil brasileira

v.1

São Paulo

2009 


\section{UNIVERSIDADE DE SÃO PAULO \\ FACULDADE DE FILOSOFIA, LETRAS E CIÊNCIAS HUMANAS DEPARTAMENTO DE LINGUÍSTICA PROGRAMA DE PÓS-GRADUAÇÃO EM SEMIÓTICA E LINGUÍSTICA GERAL}

\section{Tecendo o estético e o sensível através do bordado na literatura infantil brasileira}

\section{Mara Jane Sousa Maia}

Dissertação apresentada ao Programa de PósGraduação em Semiótica e Linguística Geral do Departamento de Linguística da Faculdade de Filosofia, Letras e Ciências Humanas da Universidade de São Paulo, para a obtenção do título de Mestre em Linguística.

Orientador: Prof. Dr. Ivã Carlos Lopes

$$
\text { V.1 }
$$

São Paulo 
AUTORIZO A REPRODUÇÃO E DIVULGAÇÃO TOTAL OU PARCIAL DESTE TRABALHO, POR QUALQUER MEIO CONVENCIONAL OU ELETRÔNICO, PARA FINS DE ESTUDO E PESQUISA, DESDE QUE CITADA A FONTE.

\begin{abstract}
Catalogação na Publicação
Serviço de Documentação do Sistema Integrado de Bibliotecas - SIBI Faculdade de Filosofia, Letras e Ciências Humanas
\end{abstract}

MAIA, Mara Jane Sousa.

Tecendo o estético e o sensível através do bordado na literatura infantil brasileira / Mara Jane Sousa Maia; orientador Ivã Carlos Lopes - São Paulo, 2009. $203 \mathrm{f}$.

Dissertação (Mestrado . Programa de Pós-Graduação em Semiótica e Linguística Geral. Área de Concentração: Semiótica e Linguística Geral) . Faculdade de Filosofia, Letras e Ciências Humanas.

1. Semiótica Plástica 2. Literatura Infantil 3. Linguística 4. Sincretismo I. Título. 


\title{
Tecendo o estético e o sensível através do bordado na literatura infantil brasileira
}

\author{
Dissertação apresentada ao Programa de Pós- \\ Graduação em Semiótica e Linguística Geral do \\ Departamento de Linguística da Universidade de São \\ Paulo, para obtenção do título de Mestre em \\ Linguística. \\ Área de Concentração: Semiótica e Linguística Geral
}

Aprovado em:

BANCA EXAMINADORA

Prof. Dr. Ivã Carlos Lopes

Instituição: FFLCH . USP

Presidente

Profa. Dra. Norma Discini de Campos

Instituição: FFLCH . USP

Titular

Prof. Dr. Jean Cristtus Portela

Instituição: UNESP. Externo

Titular 
À Deus, minha força e meu guia.

Às mulheres da minha vida:

minha mãe,

minha irmã

e minha filha.

À música, meu acalanto e minha inspiração. 


\section{AGRADECIMENTOS}

Ao professor Ivã Carlos Lopes, por acreditar no meu projeto e por ter sido um orientador-amigo, sendo firme e terno em suas colocações.

Às professoras Diana Luz Pessoa de Barros, Elizabeth Harkot-de-la-Taille e Norma Discini que me deram ricos conselhos acadêmicos, com bom humor e alto astral.

À Coordenação de Aperfeiçoamento de Pessoal de Nível Superior (CAPES) pela concessão da bolsa de mestrado e pelo apoio financeiro necessário à realização desta pesquisa.

À Clara Juareza Pereira da Silva que me ajudou a refazer o meu percurso.

À Sueli Ramos pela amizade e apoio incondicional, sempre serena e sensata. 
"Essas ideias de relacionar a escrita e o tecer, fiar e bordar já vinham girando havia muito tempo em meu espírito, e não havia nada demais nisso. Eu apenas estava tendo consciência de algo já perfeitamente assimilado e registrado por nossa linguagem de todos os dias, criação anônima e coletiva da nossa cultura pelos séculos afora. Mais que isso, uma noção recorrente na tradição literária." 


\section{RESUMO}

MAIA, Mara Jane Sousa. Tecendo o estético e o sensível através da bordado na literatura infantil brasileira. 2009. 203 f. Dissertação (Mestrado). Faculdade de Filosofia, Letras e Ciências Humanas, Universidade de São Paulo, São Paulo, 2009.

A literatura infantil desperta um duplo interesse: a história narrada pelo texto verbal e a depreendida das imagens que ilustram as capas e as páginas. Enquanto o texto verbal pode levar o leitor a uma compreensão do mundo e de valores culturais e morais, o texto visual pode despertar os sentidos pela experiência estésica. Do escrito ao tocado, do lido ao experimentado, o aprendizado é feito sob diferentes materialidades e discursos.

Este trabalho delimita-se a analisar cinco livros destinados ao público infanto-juvenil com ilustrações feitas pelo grupo mineiro de bordadeiros Matizes-Dumont: Exercícios de ser criança, de Manoel de Barros; A moça tecelã, de Marina Colasanti; Menino do rio doce, de Ziraldo; A bola e o goleiro, de Jorge Amado; A menina, a gaiola e a bicicleta/Céu de passarinho, de Rubem Alves e Carlos Brandão.

A fundamentação teórica adotada para a análise desse corpus é a semiótica francesa, abarcando seus desdobramentos recentes, como a semiótica das paixões, a semiótica plástica, a enunciação e a tensividade. Os desdobramentos tensivos, por sinal, caminham livremente em todas as análises como efeito de sentido.

A possibilidade de trabalhar com diferentes linhas de análise, demonstra a riqueza desse corpus que ora mostra sua força no texto verbal, ora ganha status de arte ao oferecer ao enunciatário/leitor uma gama de imagens que despertam o estético e o estésico. Temos, portanto, 
ao longo dos enunciados infanto-juvenis, a presença de diálogos plurilinguísticos e polissensoriais.

A figuratividade, tão presente e marcante neste trabalho, segue as propostas de Denis Bertrand. Outro teórico relevante a esta pesquisa é Jean-Marie Floch, com suas linhas de pesquisa a respeito do visual/pictórico, ao inserir novas categorias (constitucionais e relacionais) de análise para o plano da expressão.

Pela própria natureza dos objetos analisados, percorre-se o caminho do estético, já que este "se manifesta mediante práticas cotidianas". Esse percurso apresenta um marco importante no livro Da Imperfeição, de Algirdas Julien Greimas, que analisa textos-objeto de valor estético, depreendendo seu sentido e seu caráter sensível, em que o plano da expressão passa a ser a força motriz da obra. As descrições do autor sobre alguns textos literários mostram a "elasticidade do discurso", que vai além da superfície do texto.

Ainda a respeito da questão plástica, outras fontes teóricas estão presentes com o intuito de enriquecer e expandir as análises, procurando sempre manter o intercâmbio entre a semiótica e outras propostas de análise do pictórico. Diante dessas informações "técnicas" das artes plásticas, que possuem sua linguagem própria, torna-se possível montar uma "grade de leitura" dos textos-objeto.

Embora este trabalho trilhe pelo caminho da semiótica, tratar de textos infantis nos obriga a ter informações consistentes sobre o universo teórico da literatura. Daí o acréscimo de livros sobre este universo, incluindo obras específicas sobre literatura infantil, ilustração e diagramação.

Dessa forma, dentro dos objetivos de examinar os mecanismos de construção do sentido em textos de literatura infanto-juvenis, cada livro é analisado de acordo com a teoria da semiótica discursiva ou a da semiótica plástica. Em $A$ moça tecelã trabalha-se com as paixões no texto verbal com o intuito de apreender os efeitos de sentido de qualificações modais, aspectuais e estruturais que modificam o sujeito patemizado. Pela 
obra sincrética de Manoel de Barros são descritas as estratégias de enunciação, apontando os recursos utilizados para a construção de sentido nos textos verbais e visuais. A intertextualidade pontua o trabalho de Ziraldo ao dialogar com as obras infanto-juvenis do escritor norteamericano Mark Twain, acrescentando-se, na análise, as experiências estéticas relacionadas com as paixões. O último capítulo trata do imagético, fazendo um contraponto entre as capas dos livros $A$ bola e $o$ goleiro e A menina, a gaiola e a bicicleta/Céu de passarinhos, fundamentando-se em Floch e seus sucessores teóricos.

Por meio dessas análises busca-se acrescentar aos estudos dos textos literários e plásticos infanto-juvenis possíveis mecanismos de leitura, tendo como ferramenta teórica a semiótica francesa.

Palavras-chave: semiótica plástica; sincretismo; literatura infantil; paixões; enunciação. 


\section{ABSTRACT}

MAIA, Mara Jane Sousa. Weaving the aesthetic and sensitive through the embroidery on Brazilian children's literature. 2009. $203 \mathrm{f}$. Dissertation (Master Degree in Linguistics). Faculdade de Filosofia, Letras e Ciências Humanas, Universidade de São Paulo, São Paulo, 2009.

Children's literature brings two different concerns: the story told by the verbal text, and the one brought by the images of the book cover and of the book. The visual text can awake the senses by an aesthetic experience while what is written on the book can take the reader to a comprehension of the world and of the cultural and moral values. The learning is made possible by different matters and discourses; from what's written to what's touched, from what's read to what's experienced.

This essay was delimited to the analyses of five books made specific to children, with illustrations made by a group of embroideress from Minas Gerais called Matizes-Dumont: Exercícios de ser criança, by Manoel de Barros; A moça tecelã, by Marina Colasanti; Menino do rio doce, by Ziraldo; A bola e o goleiro, by Jorge Amado; A menina, a gaiola e a bicicleta/Céu de passarinho, by Rubem Alves and Carlos Brandão.

The theoretical basis used for the analyses of this subject is the French Semiotics, also with its deployments such as the Semiotics of Passion, Semiotics of Arts, the Enunciation, and the Tensile Semiotics. In reality, the Tensile Semiotics one goes freely through all the analyses as a sense, or meaning, effect.

The possibility of working with different forms of analyses brought up the importance of the material. It shows the strength of the verbal text, and, also, the importance of the material as a work of art since it 
offers to the readers a number of images that awakes the esthetic and aesthetic. The dialogues are plurilinguistic and polisensorial.

The figuratively, well noticed on this essay, follows the developments made by Denis Bertrand. Other important scholar for this research is Jean-Marie Floch, and its ways of working over the visual/pictorial, adding new categories (constitutionals and relational) of analyses for the expression plane.

We follow the trails of the esthetic based on the nature of the analyzed objects, since it's expressed over "ordinary" way of working. This course presents an important door on Algidas Julien Greimas book, De l'imperfection (Of the Imperfection), wich analyses texts-objects of esthetic value, gathering its meaning from the sense, and the expression plane became the main force on the work piece. His descriptions about some literary texts shows us the "elasticity of a discourse", going beyond the surface of the text.

Yet on the plastic art field, other theoretical sources are present, so it would enrich and enlarge the analyses, always trying to keep the interchange between semiotics, and other forms of analyses of the pictorial. From all these technical information about the plastic art, that contains its own language, it's possible for us to show the "screen of reading" of the text-object.

Working with children's texts forces us to have consistent information about the theoretical universe of this literature, even though the essay goes through the semiotics field. We understand from that the choice of using a book of this field, including specific works about children's literature, illustration and sketch.

This way, each book was analyzed according to a theory of the discursive semiotics or of the plastic art semiotics. On the book $A$ Moça Tecelã, we work with the passions on the verbal text, trying to pay attention to the effects of the sense by the modal, the aspectual, and the structural qualifiers that change the pathetic reaction of the subject. By Manoel de Barros' syncretic work we describe the strategies of the 
enunciation, showing the resources used for the construction of the verbal and visual texts. The intertextuality on Ziraldo's work is noticed by his dialog with children's works made by the north-American author Mark Twain, adding, on the analyses, the esthetic experiences related to the passions. The last chapter talks about the images, creating a counterpoint between the covers of the books A bola e o goleiro, and A menina, a gaiola e a bicicleta/Céu de passarinhos, based on Floch and his theoretical successors.

With this essay, we've tried to add possible ways of reading the children's literature and plastic art using the French Semiotics theoretical tools.

Keywords: plastic art semiotics; syncretism; children's literature; passions; enunciation. 


\section{SUMÁRIO}

Introdução..........................................................................18

1. Pressupostos teóricos e metodológicos ..............................25

\section{Capítulo I - Contexto histórico}

1.1. A literatura e a ilustração nos livros infanti-juvenil no Brasil ......36 1.2. A literatura e a ilustração nos livros infanto-juvenil na Europa e nos Estados Unidos .45

\section{Capítulo II - Análise do corpus}

2.1. Paixões. .56

2.1.1. O universo passional de Marina Colasanti, em $A$ moça tecelã .56

2.2. Enunciação. 75

2.2.1. As estratégias de enunciação no universo infantil de Manoel de Barros pelo conto 0 menino que carregava água na peneira.....75 2.3. Paixões, Estesias e Polifonia.......................................96

2.3.1. Diálogos e Paixões no rio de Ziraldo.......................96

2.4. Semiótica Plástica............................................. 134

2.4.1. O Barroco e o Clássico nas capas de livros infantis ilustradas pelo grupo Matizes. 
Anexos. 164

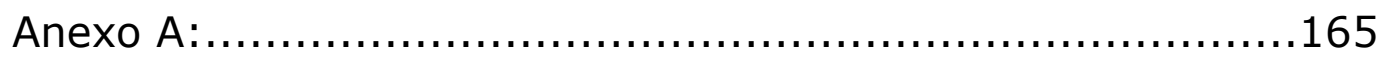

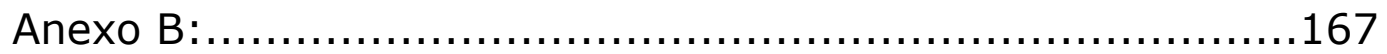

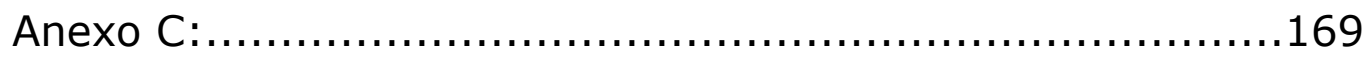

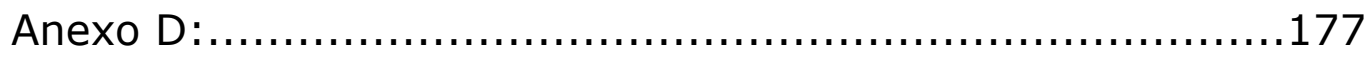

Lista de ilustrações..................................................................180

Capa do livro A moça tecelã.......................................181

Capa do livro Exercícios de ser criança..........................182

Páginas 8 do livro Exercícios de ser criança.......................183

Páginas 9 do livro Exercícios de ser criança........................184

Páginas 30 do livro Exercícios de ser criança.......................185

Páginas 31 do livro Exercícios de ser criança......................186

Capa do livro Menino do rio doce.................................187

Páginas 2 do livro Menino do rio doce...........................188

Páginas 3 do livro Menino do rio doce...........................189

Página 11 do livro Menino do rio doce...........................190

Página 14 do livro Menino do rio doce............................191

Páginas 18 do livro Menino do rio doce............................192

Páginas 19 do livro Menino do rio doce...........................193

Página 23 do livro Menino do rio doce............................194

Página 25 do livro Menino do rio doce...........................195 
Páginas 27 do livro Menino do rio doce...........................196

Páginas 28 do livro Menino do rio doce...........................197

Páginas 29 do livro Menino do rio doce...........................198

Frontispício do livro The Adventures of Tom Sawyer.................199

Ilustração da jangada em The adventures of Huckleberry

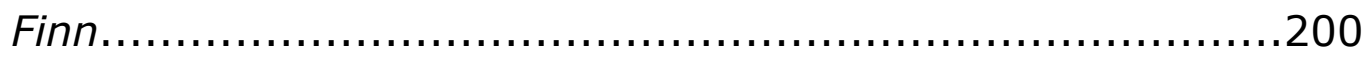

Ilustração da jangada em The adventures of Tom Sawyer.....201

Capa do livro A bola e o goleiro..................................202

Capa do livro A menina, a gaiola e a bicicleta/Céu de

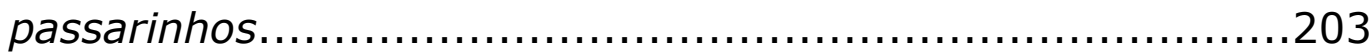




\title{
INTRODUÇÃO
}

"No descomeço era o verbo.

Só depois é que veio o delírio do verbo.

O delírio do verbo estava no começo, lá onde a criança diz:

Eu escuto a cor dos passarinhos.

A criança não sabe que o verbo escutar não funciona para cor, mas para som.

Então se a criança muda a função de um verbo, ele delira.

E pois.

Em poesia que é voz de poeta, que é a voz de fazer nascimentos -

O verbo tem que pegar delírio."

Manoel de Barros ${ }^{1}$

Os gêneros ${ }^{2}$ da literatura infantil brasileira vêm ganhando reconhecimento e se consolidando na esfera de circulação do campo literário ao ocupar um espaço cada vez maior no mercado editorial nacional. Sendo um produto mercadológico, a literatura infanto-juvenil teve que acompanhar as mudanças, rompendo estruturas obsoletas e visões estereotipadas. Nos últimos 20 anos, esse setor se profissionalizou,

\footnotetext{
${ }^{1}$ BARROS, Manoel de. 0 Livro das Ignorãças. $13^{\text {a }}$ ed. Rio de Janeiro: Record, 2007, p. 15.

2 O uso da palavra "gênero" é recorrente nesse trabalho. Ela é aqui adotada para determinar uma categoria, no caso, a narrativa literária infanto-juvenil, pertencente à esfera de circulação do campo literário. Nós justificamos seu uso, tendo como base a definição dada por Fiorin (2004, p. 2):
}

\begin{abstract}
os gêneros são organizações relativamente estáveis caracterizadas por uma temática, uma forma composicional e um estilo. A temática não é o assunto de que trata o texto, mas é a esfera de sentido de que trata o gênero [...]. Os gêneros são inúmeros, pois dizem respeito à esfera das atividades cotidianas [...], bem como à esfera das atividades institucionalizadas [...].
\end{abstract}

Outra fonte teórica é o Dicionário de Semiótica que diz: "o gênero designa uma classe de discurso reconhecível graças a critérios de natureza socioletal. Estes podem provir de uma classificação implícita que repousa nas sociedades de tradição oral, sobre a categorização particular do mundo, quer de uma 'teoria dos gêneros' que, para muitas sociedades, se apresenta sob a forma de uma taxionomia explícita, de caráter nãocientífico. Dependente de um relativismo cultural evidente e em postulados ideológicos implícitos." (GREIMAS; COURTÉS, s.d, p. 202). 
seduziu talentosos e consagrados escritores, conquistou o público infantil e forçou a profissionalização e criatividade de ilustradores e artistas plásticos envolvidos com esse universo lúdico, porém exigente e dinâmico.

A inclusão das categorias "Literatura Infantil" e "Ilustradores de Livros Infantis e Juvenis" na principal premiação literária do país, o "Prêmio Jabuti", da Câmara Brasileira do Livro (CBL), e a credibilidade que a Fundação Nacional do Livro Infantil e Juvenil (FNLIJ) tem hoje como instituição que reconhece, premia e divulga as obras de qualidade destinadas às crianças e adolescentes, evidenciam a importância que tal setor vem ocupando.

Percebendo seu potencial e atendendo aos novos desafios impostos por este gênero em expansão, escritores e designers gráficos estão buscando novas formas de se comunicar com as crianças, que vão além do texto escrito. Passou-se a investir na comunicação através da imagem e da visualidade, ancorando o texto ou criando possibilidades de novas leituras. Lê-se o texto escrito e o texto visual, acompanhando a rima e o ritmo das frases, mas acompanhando também as formas, as linhas, as cores e os desenhos. O espaço das letras compartilha com as imagens uma (nova) narrativa, construindo um texto plurissignificativo. A qualidade artística busca englobar elementos textuais e pictóricos, gerando um fenômeno pluriestilístico e plurivocal, incluindo vários códigos, estreitando o diálogo entre o texto verbal e o texto visual.

No Brasil, nosso artista tem conseguido misturar as estéticas rural, folclórica e tropical "sampleando" imagens urbanas e internacionais e colocando no mercado livros de altíssima qualidade e riquíssimos em informações visuais. [...] Ganham status de livro de arte (LINS, 2002, p. 51).

É um equívoco, porém, achar que somente os livros destinados às crianças e aos jovens têm a preocupação com o projeto gráfico e com a inclusão de belas ilustrações. Voltando no tempo, lembraremos que, na Idade Média, o texto era escrito à mão com riquíssimos detalhes nas letras. Era um trabalho artesanal realizado, principalmente, por monges 
copistas com o propósito de ser belo e com uma função religiosa, "demonstrando devoção, respeito e poder" (LINS, 2002, p. 19).

No Brasil, ao situarmos a década de 1950, encontraremos uma vanguarda poética que incorpora:

a dimensão óptica do signo e o cuidado artesanal com a diagramação. Ou seja, no requinte da poesia concreta, fazse presente o nosso estatuto do visual não só no mundo moderno, como nas representações dele que se querem modernas (LAJOLO; ZILBERMAN, 2006, p. 14).

Passa-se a ter uma preocupação maior com os trabalhos gráficos, inclusive com a tipografia, produzindo livros sofisticados e/ou artesanalmente elaborados. Os poetas concretistas davam demasiada importância ao espaço gráfico-visual como parte integrante do texto verbal e da construção de sentido. Ao transformar a poesia em objeto visual, inevitavelmente, o projeto gráfico ganha importância.

A ilustração de livros com fotografias de bordados não é uma exclusividade ou originalidade da narrativa literária infanto-juvenil. Desde os anos 1980 encontramos exemplares de livros com essa proposta. O poeta e sacerdote nicaraguense Ernesto Cardenal nessa mesma década, por exemplo, tem uma obra/coletânea publicada com ilustrações de bordados feitos por um grupo de índias da Nicarágua, embora as ilustrações cumprissem apenas a função de ancoragem, isto é, o enunciado visual apenas ratificava o enunciado verbal.

O texto escrito conta uma história recheada de imagens nas linhas e nas entrelinhas. A imagem complementa e enriquece esta história, a ponto de cada parte de uma imagem poder gerar diversas histórias. O texto e a imagem juntos dão ao leitor o poder de criar na sua cabeça a única história que realmente interessa. A história dele (LINS, 2002, p. 31).

A escritora Ana Maria Machado, em seu livro Texturas: sobre leituras e escritos, relata sua longa caminhada para a confecção de sua obra Ponto a Ponto em busca de bordados e bordadeiras que ilustrassem suas 
histórias (releituras de contos de fadas e contos populares de vários cantos do mundo) sobre fiar, tecer e bordar. Ela buscava um fio condutor que tecesse os dois textos: visual e verbal.

No cenário atual, surgem ilustradores talentosos casando suas ideias e projetos originais com as histórias de escritores em busca de uma nova linguagem que atraia e prenda a atenção desse pequeno leitor. No final da década de 1980, seis integrantes da família Dumont, da cidade de Pirapora (MG), formaram o grupo Matizes e iniciaram seu trabalho como "bordadores" de livros. Os desenhos feitos pelo artista plástico Demóstenes Vargas ganham formas, cores e "vida" ao serem bordados pelos demais integrantes do grupo. Os ilustradores utilizam materiais diversos como: seda, algodão, lã e gorgorão, de modo que a tela vai sendo preenchida por linhas retas e arredondadas, com traços leves e fortes, formas fechadas e abertas, cores claras e escuras, criando efeitos de sentido em cada imagem elaborada.

Parceiros de grandes escritores bordaram (Cf. Anexo A) ilustrações para livros de Manoel de Barros (Exercícios de ser criança), Ziraldo (Menino do rio doce), Jorge Amado ( $A$ bola e o goleiro), Rubem Alves ( $A$ menina, a gaiola e a bicicleta e Os três reis), Carlos Brandão (Céu de passarinhos), Marina Colasanti (A moça tecelã) e Thiago de Mello (Amazonas: águas, pássaros, seres e milagres), entre outros destinados ao leitor adulto. Muitas dessas obras foram premiadas pelas principais instituições de apoio à leitura à criança e ao adolescente (Cf. Anexo B), reconhecendo, assim, o valor estético das obras como porta de entrada de comunicação com as crianças.

[...] A tendência de as crianças lerem ilustrações, e não texto, implicou a visão de que capas atraentes demais degradam conteúdos importantes.... As crianças, porém, não fazem uma separação tão automática entre forma e conteúdo, e podem estabelecer um vínculo emocional com um livro do mesmo modo como fariam com um brinquedo (POWERS, 2008, p. 6). 
Embora produzam ilustrações para escritores de estilos e com enfoques temáticos próprios, os traços dos bordados desta família preservam suas características, possibilitando identificar modos de construção, isotopias, configurações discursivas. São textos (visuais) feitos de vários fios que se interligam e constroem uma teia de sentido.

Uma vez que estes livros podem ser tratados como objetos de arte, caminha-se para o estético. O estético, por sua vez, manifesta-se pelo estreitamento do diálogo entre a imagem visual e a palavra. Ao estabelecer um diálogo entre os elementos que compõem a obra, a ilustração ganha uma posição de destaque. É ela que capta e recria o texto verbal. No universo da literatura infantil, o estético está ligado a uma ética do imaginário:

O imaginário é entendido aqui como criação contínua, sóciohistórica e psíquica que se expande pluridimensionalmente, colocando em movimento as imagens produzidas pelo ser humano. Para Wolfgang Iser, o fictício mobiliza o imaginário no texto literário, induzindo uma espera por uma constelação do jogo..., o fictício pressiona o imaginário a assumir uma forma, oferecendo, então, a condição constitutiva para o estético. Um dos grandes desafios da literatura infantil é movimentar o imaginário na sua maior potência e, ao mesmo tempo, lidar com o limite do discurso (TURCHI, 2004, p. 38).

A proposta deste trabalho é dar um tratamento semiótico ao estético, extraindo sua dimensão sensível, ou melhor, "seus modos de significar". São textos - verbais e visuais - que produzem uma espécie de encantamento, levando a certas rupturas e até mesmo a certas colisões. "Se esta vivência sensível opera transformações é porque o arranjo estético produz quebras de estereótipos e de simulacros preconstituídos" (OLIVEIRA, 2002, p. 11). Há uma gama de sentidos oferecidos ao leitor infantil que necessita de diferentes vozes narrativas, para retratar as diversidades culturais.

A literatura infantil contemporânea vem trabalhando com a ideia do sensível, da emoção coletiva, do humor, e é aí que se faz necessário 
compreender a construção de sentidos encontrada no plano onírico que, segundo Greimas (2002, p. 45), "trata o imaginário como uma potencialidade de construção do objeto".

Seguindo nessa esteira, a comunicação visual ganha crédito neste gênero ao acrescentar elementos de significação, proporcionando choques sensoriais, especialmente visuais e táteis, abrindo, assim, espaço para várias leituras e tendo como porta de entrada a capa do livro. Ocorre neste ponto um feliz casamento entre o verbal e o não-verbal, pois o texto poético adquiriu características estruturais semelhantes às do texto pictórico funcionando de forma sincrética. "Ao retomarem um ao outro, acrescentam nova dimensão de sentido ao texto primeiro porque explora [...] as possibilidades plásticas de cada código significante. Dessa forma, a leitura de um amplia o sentido do outro" (TEIXEIRA, 2004, p. 243).

Vale ressaltar, porém, que as ilustrações aqui analisadas não atuam como colagem, "onde cada elemento material se apresenta como acréscimo, superposição, e as relações se fazem por adição de sentidos em reiteração ou em contraponto" (TEIXEIRA, sd, p. 13). A semioticista francesa Anne Beyaert-Geslin ${ }^{3}$ explica que essa arte fragmentada é elaborada a partir da aplicação ou da colagem de uma porção de substâncias estranhas sobre a superfície de um quadro, que "além da simples citação de uma obra estrangeira, além da importação de um material, ela é, por assim, dizer, um fragmento já semantizado, descontextualizado e livre para um novo universo de sentido" (BEYAERTGESLIN, 2005, p. 137).

Buscamos, com esse corpus, analisar os textos sincréticos enquanto simulacros da experiência estética, depreendendo os modos de significar nos textos e distinguindo os efeitos de sentido produzidos. Ao identificarmos as apreensões estabelecidas entre sujeito e objeto, além das manifestações externas desse sujeito diante dessa experiência,

\footnotetext{
${ }^{3}$ Autora do artigo "La typographie dans le collage cubiste: de I'écriture à la texture", publicado no livro L'écriture entre support et surface, editora L'Harmattan, Paris, 2005.
} 
podemos resgatar os elementos figurativos que oferecem recursos de apreensão estética.

A isotopia, por exemplo, sendo um elemento da figuratividade, dá "a permanência de um efeito de sentido ao longo da cadeia do discurso" (BERTRAND, 2003, p. 153). Ela é a responsável pelas rupturas, fraturas e colisões nos textos (inclusive o não-verbal), será reconhecida ao se examinar as recorrências isotópicas como modo de construção a partir das ilustrações dos livros, além do texto verbal. A figuratividade no discurso plástico, por exemplo, "pode construir-se entre iconicidade e tematização, entre plasticidade e figuração" (TEIXEIRA, 2004, p. 245).

Em muitos momentos, a tensividade também entra como ferramenta de análise da aspectualização (tempo e espaço), a fim de nos fazer compreender as instâncias do tempo entre Expressão e Conteúdo, pois são nelas que ocorrem as graduações e modulações transformadoras do mítico ao social, do passado para o presente/futuro. 


\section{Pressupostos teóricos e metodológicos}

Este trabalho busca estabelecer um paralelo entre a literatura e as artes plásticas, encontrando suas semelhanças estruturais, mas sem esquecer suas composições materiais distintas.

As pesquisas desta dissertação focaram nos livros literários direcionados ao público infantil com ilustrações de bordados feitas pelo grupo Matizes, com histórias de autores distintos e contendo uma rica narrativa enriquecida por cores e formas das ilustrações, além do texto verbal. A opção por esse gênero se deve aos poucos estudos que relacionam o visual e o verbal com o estético, e que foram realizados tendo como campo teórico a semiótica greimasiana.

É relevante dizer que esses bordados fazem parte da cultura popular de um povo, estabelecendo, assim, relações afetivas, culturais e de memória com seu destinatário. Sabemos que o artesanato é uma forma de manifestação artística não individual, pois compartilha e expressa uma cultura local por meio de suas várias vozes. São valores, são afetos, são narrativas de um cotidiano. Cada "família" de bordadeiras tem sua "assinatura", isto é, um estilo próprio e único formando a identidade do grupo. Os traços que se repetem, que se formam e que se firmam constroem "um efeito de sentido, uma construção do discurso" (DISCINI, 2004, p. 59).

Como recorte metodológico, nos respaldamos nas categorias de totus e unus propostas por Discini (2004):

O unus pressupõe o totus, o "bloco inteiro", a totalidade integral, a qual "destaca a absorção dos indivíduos isolados numa massa indivisível"... O totus supõe o mais-de-um, mas considerado do ponto de vista da semelhança, que implica um efeito de unidade, unus (DISCINI, 2004, p. 34).

Dessa forma, com um corpus tão extenso, foi necessário reduzir o número de exemplares a serem analisados, porém mantivemos a totalidade discursiva e plástica. Assim sendo, recortamos partes da 
totalidade, os sete livros bordados pela família Dumont, e selecionamos os cinco títulos abaixo (ver no item Anexos as imagens das capas em seu tamanho original):

1. Exercícios de ser criança, de Manoel de Barros;

2. A moça tecelã, de Marina Colasanti;

3. Menino do rio doce, de Ziraldo;

4. A bola e o goleiro, de Jorge Amado;

5. A menina, a gaiola e a bicicleta/Céu de passarinho, de Rubem Alves e Carlos Brandão.

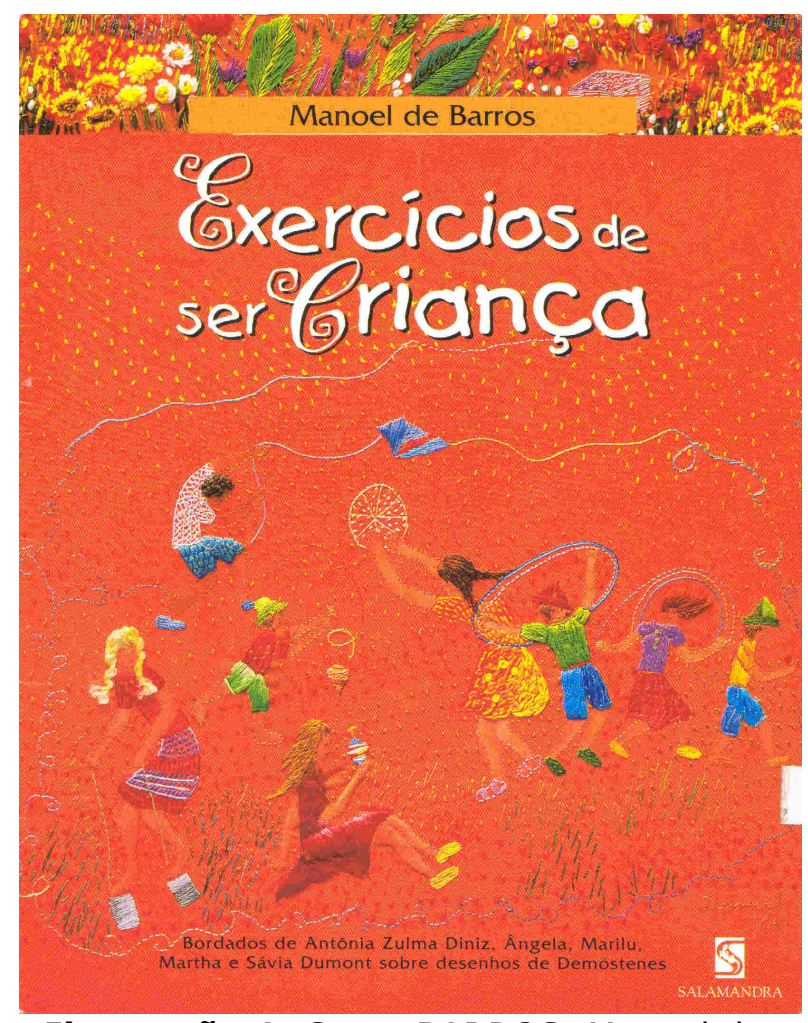

Ilustração 1. Capa. BARROS, Manoel de. Exercícios de ser criança. Rio de Janeiro: Salamandra, 1999.

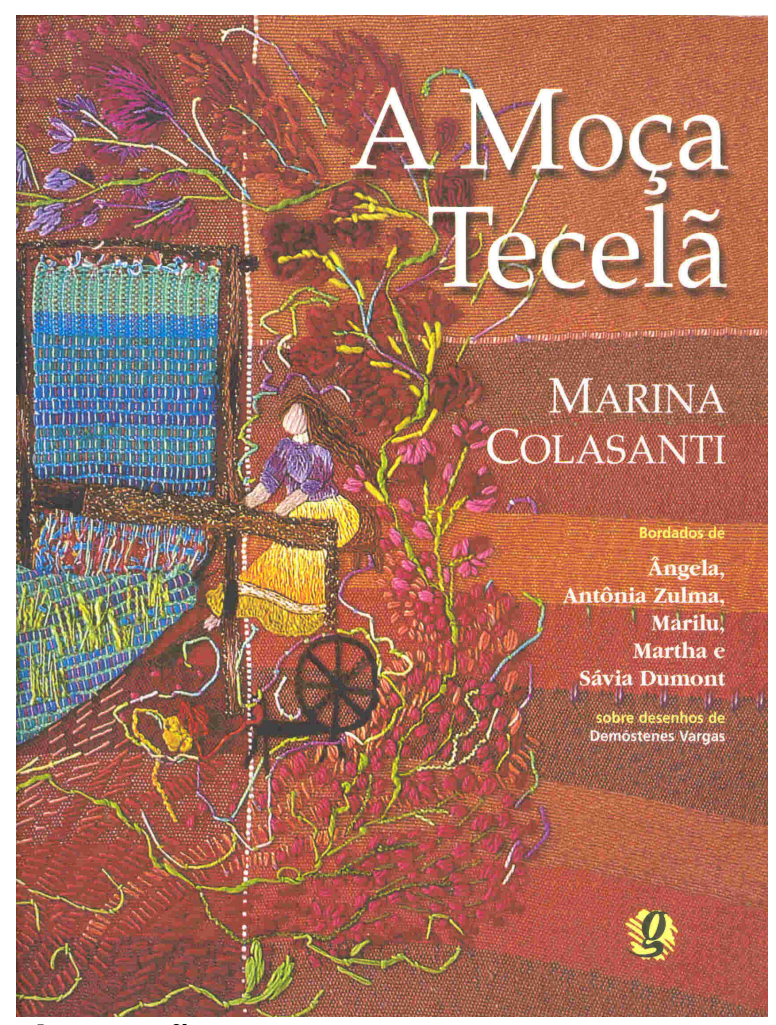

Ilustração 2. Capa. COLASSANTI, Marina. A moça tecelã. São Paulo: Global, 2004. 


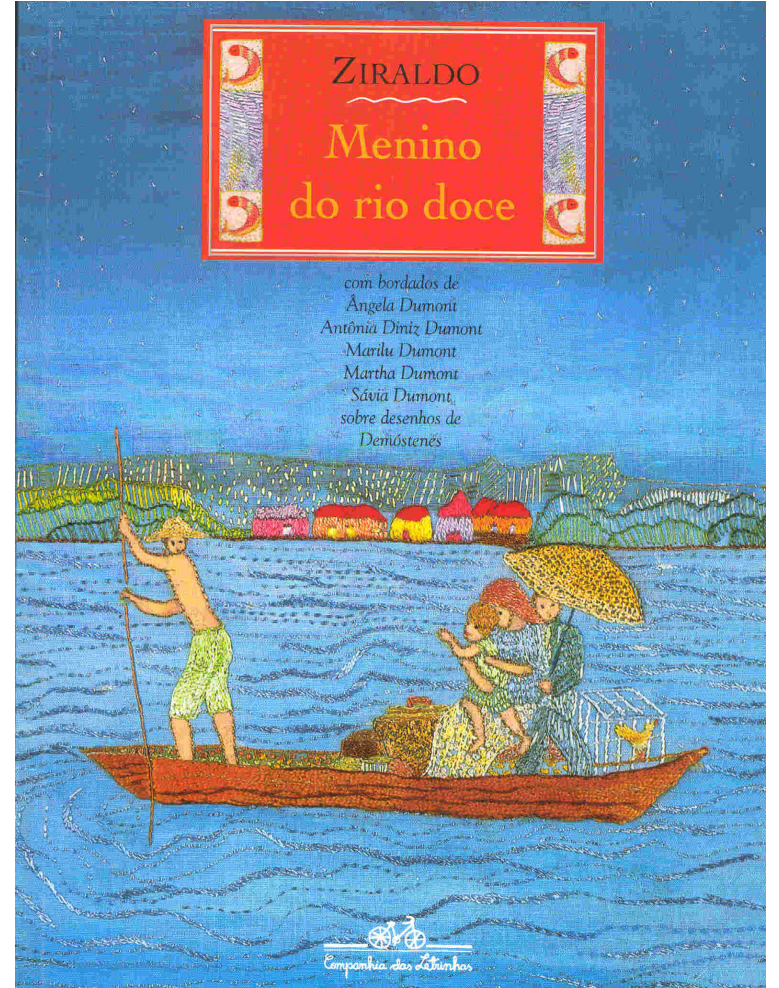

Ilustração 3. Capa. ZIRALDO. Menino do rio doce. $12^{a}$. reimp. São Paulo: Companhia das Letrinhas, 2006.

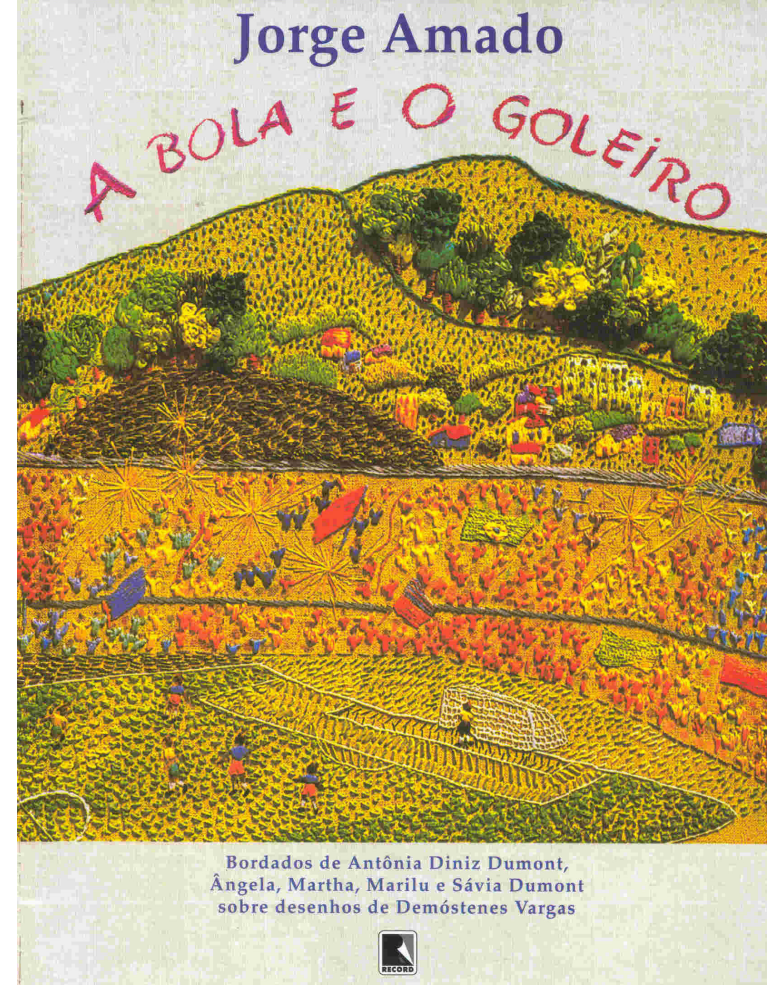

Ilustração 4. Capa. AMADO, Jorge. A bola e o goleiro. $14^{a}$ ed. Rio de Janeiro: Record, 2007.

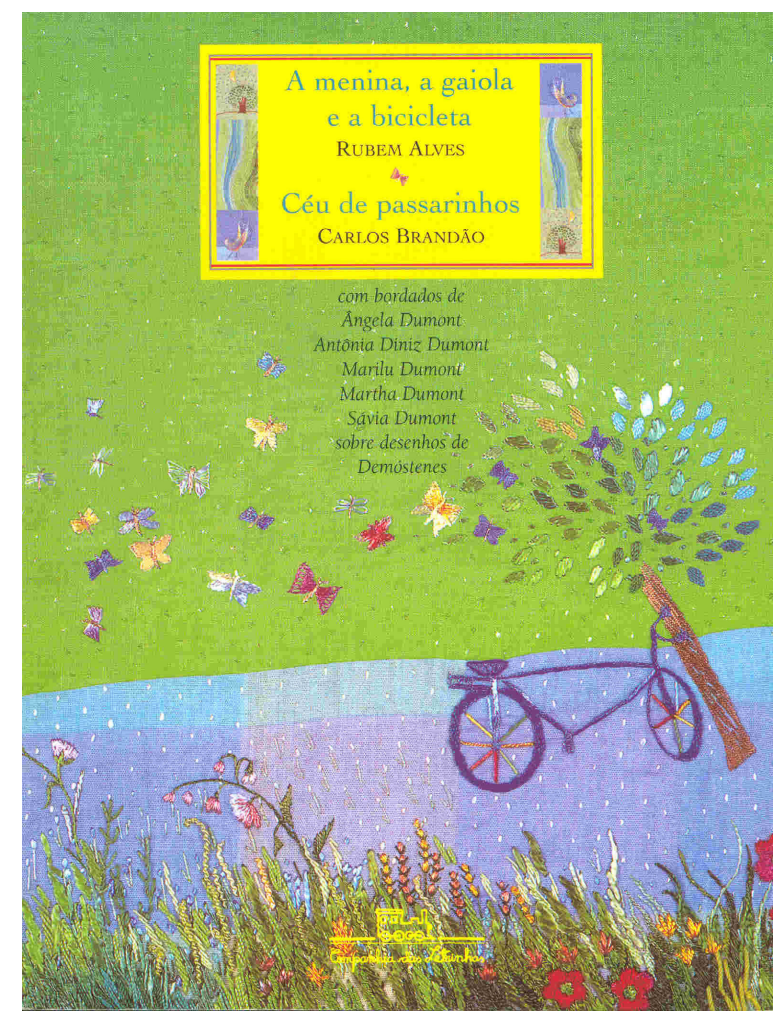

Ilustração 5. Capa. ALVES, Rubem; BRANDÃO, Carlos Rodrigues. $5^{\mathrm{a}}$ reimp. A menina, a gaiola e a bicicleta/Céu de passarinhos. São Paulo: Companhia das Letrinhas, 2004. 
Novamente, fomos buscar respaldo teórico para este recorte, se fundamentando em Viggo Brøndal, que explica que omnis, termo numérico,

designa uma totalidade mais sutil ou diferenciada. Ele exprime a reunião de indivíduos num grupo ou numa comunidade. As partes componentes são reconhecíveis, de um lado, como reais, de outro, como constituintes de um conjunto (DISCINI, 2004, p. 15).

Voltando para Discini (2004), temos, então, uma totalidade integral, um bloco coeso, preservando a unidade de sentido e as "relações recorrentes de sentido, detectadas em mais de um texto" (DISCINI, 2004, p. 35). Preservamos a unidade plástica e o gênero, e abrimos o leque de leituras ao poder analisar textos com estilos e temas tão distintos. A escritora Marina Colasanti, por exemplo, constrói suas histórias em um passado impreciso, por meio de uma narrativa bastante simbólica, trabalhando com o amadurecimento de seus personagens. Já Ziraldo, caracteriza-se mais por uma prosa leve, com histórias de iniciação, mostrando todo o percurso de seus protagonistas até chegarem à maturidade. O escritor Manoel de Barros, por sua vez, possui uma poética inusitada e lúdica, rompendo, desse modo, com essa linearidade do texto.

O totus supõe o mais-de-um, mas considerado do ponto de vista da semelhança, que implica um efeito de unidade, unus... Omnis implica uma totalidade, mas não levando em conta as semelhanças. É uma totalidade numérica (DISCINI, 2004, p. 34-35).

Seguindo na análise, vemos que a literatura destinada às crianças, ao adotar um jogo ficcional por meio da memória e da imaginação, vem rompendo de forma criativa e emotiva com as estruturas padronizadas da narrativa direcionada a esse público. Completando esse estranhamento e esse deslumbramento diante da obra, as ilustrações fincam seu papel de importância e relevância na construção de sentido e no prazer da leitura, remetendo ao universo infantil e aos modos de ser criança. 
As ilustrações constroem uma espécie de "costura" em torno do texto verbal, dialogando com ele e complementando o seu significado, de forma bem integrada que estimula o leitor a perceber sua importância textual (CORTEZ, 2004, p. 371).

Contudo, é no plano visual que poderemos trabalhar as sensações geradas através do sensorial, partindo do mais superficial (eidético), passando pelo cromático e chegando ao mais profundo, que é a luz. Segundo Greimas (2002, p. 36), "o tato se situa entre as ordens sensoriais mais profundas, ele exprime proxemicamente a intimidade optimal e manifesta, no plano cognitivo, a vontade de conjunção total".

Os bordados parecem despertar essas sensações, permitindo uma experiência (extensa e intensa) visual e tátil, por meio de suas cores, suas formas, suas texturas e seus traços. Mais do que isso: eles contam histórias, há uma narrativa que recuperamos através do Plano do Conteúdo no texto verbal, recriado no texto visual.

O livro Da Imperfeição, de A. J. Greimas, que analisa a experiência estética em vários contos, vem ao encontro deste corpus ao oferecer ferramentas de análise sobre objetos plásticos. Essa obra desencadeou e amadureceu este trabalho ao apontar, como análise, o estético e o sensível, partindo dos bordados que ilustram os livros selecionados, ou de textos que incluem este ofício, como $A$ moça tecelã, de Marina Colasanti.

$\mathrm{Na}$ questão imagética, expandimos o leque teórico, incluindo, além das propostas da Semiótica Francesa, teorias das artes plásticas, da estética e do designer, para abarcar a plasticidade dos livros-objeto. Ao ampliar as fontes, encontramos pontos em comum com a semiótica que só enriqueceram e ampliaram as análises.

Em Era Uma Vez Uma Capa, de Allan Powers, o autor faz um apanhado histórico das capas de livros infantis desde o século XIX, na Europa e América do Norte. De forma didática, o escritor explica a construção de cada capa e sua importância histórica no cenário literário. Por meio da riqueza de dados e detalhes, ele aguça pontos pertinentes e 
instigantes quanto ao caráter do projeto gráfico e sua importância na construção de sentido de cada obra, individualizando-as. Na última análise desta pesquisa, ao trabalharmos exclusivamente com a plasticidade nas capas de dois livros, o autor também se faz presente.

\begin{abstract}
A capa, sem dúvida, cumpre um papel no processo de envolvimento físico com o livro, pois, embora não se possa olhá-la enquanto se lê, ela o define como objeto a ser apanhado, deixado de lado e talvez conservado ao longo do tempo [...]. Penso que uma das razões é a organização hierárquica da capa, com figuras em diferentes quadrantes, como nichos arquitetônicos (POWERS, 2008, p. 7).
\end{abstract}

$\mathrm{Na}$ questão estética de objetos artísticos e de designer, nos abastecemos em uma rica leitura que vai do filósofo Gilles Deleuze, passando pelo semioticista peirceano Edgar Roberto Kirchof, pelo historiador de artes Heinrich Wölfflin, chegando até a semiótica francesa sob a tutela de Jean-Marie Floch e Anne Beyaert-Geslin.

Em Francis Bacon: A lógica da sensação, Deleuze traz um olhar sobre a visão e o tato como componentes da apreensão estética que foi operacionalizado na análise das ilustrações da dissertação. Kirchof, em Estética e biossemiótica, trata da percepção estética do ser humano, trabalhando, entre outras coisas, com o tátil e a visão, elementos essenciais na análise pictórica. $O$ autor traz reflexões interessantes nas quais os sentidos são responsáveis pela percepção estética, gerando sensações e sentimentos que desencadeiam as forias. Segundo ele, "o tato oferece a pressão e a temperatura dos objetos, capazes de remeter a interpretantes como macio, áspero, frio e doloroso, constituindo um processo semiótico" (2008, p. 191).

Ainda no universo pictórico, temos um sólido suporte teórico em Jean-Marie Floch, que possui linhas de pesquisa a respeito do visual/pictórico, e propõe novas categorias (constitucionais e relacionais) de análise para o plano da expressão, o qual fora precariamente explorado até então. A mesma fonte em que Floch se abasteceu para desenvolver suas propostas teóricas também está incluída nesta pesquisa: o 
historiador Heinrich Wölfflin, através de sua obra Conceitos fundamentais da história da arte.

Em seu livro Identités Visuelles, Floch estuda objetos visuais em sua plasticidade, inserindo elementos de análise pertencentes ao universo pictórico, porém em fraternidade com as teorias semióticas, estabelecendo um sistema semi-simbólico e caracterizando a relação entre forma do conteúdo e forma de expressão do visual. Essas categorias plásticas (topológica, eidética e cromática) também provocam efeitos de sentido, pois criam figuras (isotopias/traços repetidos) que constroem o discurso.

Na análise das capas de livros, resgatamos as propostas de Floch ao tratá-las como textos-objeto, em que as categorias estéticas barroca e clássica definem estilos e constroem efeitos de sentido pelas características próprias de cada uma. Por exemplo, o livro $A$ bola e o goleiro, de Jorge Amado, apresenta fortes características pictóricas do barroco, enquanto a obra A menina, a gaiola e a bicicleta/Céu de passarinho, de Rubem Alves e Carlos Brandão, com seus traços lineares, aproxima-se da estética clássica.

Com esses livros-objeto trabalhamos por meio da figuratividade, a fim de chegar à produção de sentido. Por ela, extrairam-se os elementos culturais, sociais e, até mesmo, ideológicos, permitindo que os conteúdos mais concretos se sobrepusessem aos trajetos temáticos mais abstratos, constituintes do sentido.

Na semiótica plástica, a figuratividade mantém seu papel importante como elemento construtor de sentido, levando a uma leitura cultural do mundo ao "assumir feixes de traços visuais de densidade variável, aos quais constitui em formantes figurativos, dotando-os de significados, transformando assim as figuras visuais em signos-objeto". (BERTRAND, 2003, p. 157).

Ainda no universo figurativo, ganha destaque a isotopia, que "assegura a repetição, pela recorrência, dos elementos semânticos que se 
repetem de uma frase a outra, garantindo a continuidade figurativa e temática do texto" (BERTRAND, 2003, p. 187).

Essa repetição se faz presente tanto no texto verbal quanto no visual. No Dicionário de Semiótica, isotopia é definida como

a recorrência de categorias sêmicas, quer sejam estas temáticas (ou abstratas) ou figurativas [...], distinguir-se-ão correlativamente isotopias figurativas, que sustentam as configurações discursivas, e isotopias temáticas, situadas em um nível mais profundo, conforme o percurso gerativo (GREIMAS, COURTÉS, s.d, p. 246).

Sem dúvida, a base das análises é sempre da semiótica francesa, incluindo propostas mais atuais como a teoria tensiva, sob domínio de Jacques Fontanille e Claude Zilberberg. Contudo, optamos em trabalhar a tensividade como efeito de sentido, e não como gerador de sentido. As demais teorias são casadas com ela, acrescentando ferramentas de análise e de compreensão dos textos plásticos. Parece-nos pertinente a presença dessas outras teorias (artes plásticas, semiótica peirceana, filosófica), por permitirem vários olhares sobre o mesmo objeto, enriquecendo a pesquisa e a análise do corpus.

Nas análises textuais, restringimo-nos aos teóricos da semiótica discursiva. A análise da figuratividade, tão presente e marcante neste trabalho, está embasada nos trabalhos e propostas de Denis Bertrand. É através da própria figuratividade que se instalam tempo, espaço, objetos e valores, tanto nos textos verbais, quanto nos não-verbais.

A figuratividade não é uma simples ornamentação das coisas, ela é esta tela do parecer cuja virtude consiste em entreabrir, em deixar entrever, graças ou por causa de sua imperfeição, como que uma possibilidade de além (do) sentido. Os humores do sujeito reencontram, então, a imanência do sensível (GREIMAS, 2002, p. 74).

Nesta dissertação serão analisados três textos, três narrativas de autores distintos, com estilos próprios, com uma rica gama de leitura e de 
interpretação. Para cada um, optamos por usar uma teoria ou até mesmo o casamento entre propostas teóricas diversas.

A enunciação e as paixões permeiam toda esta pesquisa em graus diferentes, conforme a resistência de cada texto, seja escrito, seja pictórico. Novamente, ocorre um encontro com Greimas e seus sucessores - como Fontanille e Fiorin - que nos forneceram ferramentas práticas para as análises.

No estudo do texto $A$ moça tecelã, de Marina Colasanti, a semiótica das paixões é a força motriz. Vimos "nascer" e "morrer" uma paixão, mostrando "o ponto de vista do objeto, de crises aspectuais e, do ponto de vista do sujeito, suas crises fiduciárias, tanto umas quanto as outras assegurando ou não a continuidade passional" (FONTANILLE; ZILBERBERG, 2001, p. 277).

No conto $O$ menino que carregava água na peneira, de Manoel de Barros, a enunciação é o carro-chefe. Procuramos compreender e descrever as estratégias de enunciação dessa obra sincrética, apontando os recursos utilizados para sua construção. E, por se tratar de um livro que caminha para o estético, analisamos o texto sincrético, enquanto simulacro da experiência estética, percebendo quais os elementos figurativos que oferecem recursos para essa apreensão.

No livro Menino do rio doce, de Ziraldo, iniciamos a análise observando os desencadeamentos das paixões pelos sentidos e seus efeitos estésicos. Em seguida, fazemos uma ponte entre esse texto e duas obras do escritor norte-americano Mark Twain destinadas ao público infanto-juvenil, tendo como respaldo teórico a intertextualidade e a interdiscursividade. As aventuras de Tom Sawyer e As aventuras de Huckleberry Finn mantém diálogos com a obra brasileira além do textual, pontuando o texto imagético.

Em Greimas e Courtés (s.d, p. 242), a segunda definição sobre intertextualidade diz: "esta implica, com efeito, a existência de semióticas (ou de "discursos") autônomas no interior das quais se sucedem processos de construção, de reprodução ou de transformação de modelos, 
mais ou menos implícitos". Isso significa que há a incorporação intencional de um texto em outro. Já a interdiscursividade vai ao encontro do discurso do outro, inserindo "percursos temáticos e/ou percursos figurativos, tema e/ou figuras de um discurso em outro" (FIORIN, 2003, p. 32).

Voltando para as paixões, esse conto de Ziraldo tem uma forte carga afetiva. Seu rio adquire características humanas, tornando-se responsável pela avalanche de emoções que afetam e constroem aquele menino que cresce. Esse crescimento, por sinal, é figurativizado pelos diferentes barcos, relacionados sempre a um momento de aprendizagem e amadurecimento, mas também de afeto, que é mostrado através das relações de profundidade e superficialidade, de expansão e de condensação, as quais serão analisadas sob o olhar da semiótica tensiva.

Ainda na questão das paixões, trabalhamos relacionando-as com a experiência estética, tendo como orientação de análise o livro $D a$ Imperfeição, de Algirdas Julien Greimas. Procuraremos descrever como esses arranjos estéticos provocam mudanças no sujeito e nos valores culturais.

Todas as análises feitas relacionam os planos de conteúdo e de expressão com os dois sistemas, plástico-pictórico e poético. Desse modo, pudemos elaborar um trabalho intersemiótico respeitando o estatuto e as particularidades de cada linguagem, aproximando o texto literário ao das artes plásticas, pois ambos "movimentam-se num mundo de perspectivas e a produção artística deles encontra a sua razão de ser na plurivalência estética" (CORTEZ, 2003, p. 366). 
CAPÍTULO 1: CONTEXTO HISTÓRICO 


\subsection{A literatura e a ilustração nos livros infanto-juvenis no Brasil}

A história da literatura brasileira tem quatro momentos importantes de rupturas e mudanças que refletiram de forma significativa na leitura, na formação do leitor-mirim e na produção mercadológica, segundo o professor e pesquisador José Nicolau Gregorin Filho ${ }^{4}$. São elas:

1. Precursores (Brasil colônia até a década de 1920);

2. Lobatiano (década de 1920 a meados dos anos 80);

3. Pós-Lobatiano (meados dos anos 80 até início da década de 1990);

4. Contemporâneo (meados nos anos 90 até hoje).

No primeiro momento, do Brasil colônia até a década de 1920, a produção literária era escassa, com pouquíssimos livros elaborados e disponíveis para a população. As obras encontradas nesse período são traduções de obras estrangeiras, principalmente de origem europeia.

Sendo uma colônia, o Brasil teve de se submeter às regras da corte portuguesa, que proibia a produção de livros. A alfabetização, feita pelos jesuítas, restringia-se à leitura de textos bíblicos, com a inserção de valores culturais e morais dos brancos europeus. O acesso à leitura foi gradual e lento, mesmo assim, restrito à produção europeia, principalmente francesa e inglesa. As histórias se constituíam de fábulas, contos de fadas, de cavalaria, todas carregadas de moralismo e religiosidade. As crianças liam Charles Perrault, Júlio Verne, Condessa de Ségur, Jonathan Swift e Daniel Defoe. E, claro, a Bíblia.

De acordo com as pesquisas das professoras Marisa Lajolo (2006) e Regina Zilberman (2006), somente em 1808, com a implantação da Imprensa Régia, publicou-se a tradução de As aventuras pasmosas do Barão de Munkausen. Dez anos mais tarde, é impressa a coletânea Leitura para meninos, contendo uma coleção de histórias morais relativas aos

\footnotetext{
4 Anotações de aula (curso "Leitura, Literatura e Educação no Brasil", ministrado no segundo semestre de 2007, pelo DLCV/FFLCH/USP).
} 
defeitos ordinários às idades tenras, e um diálogo sobre geografia, cronologia, história de Portugal e história natural, do escritor José Saturnino da Costa Pereira.

No final do século XIX, com a proclamação da República e a criação do mercado interno, além da sua abertura ao mercado exterior, ocorre uma mudança estrutural no Brasil. A industrialização possibilita a formação de uma classe operária média, ávida por consumir e por adquirir uma educação formal e cultura. Surgem as primeiras revistas femininas, romances e livros infantis, embora esses tivessem um forte caráter didático-escolar.

Alguns títulos destinados aos jovens são lançados nessa mesma época, porém sem grande repercussão. São gotas d'água num oceano improdutivo. O leitor continua tendo acesso a livros traduzidos ou adaptados da literatura estrangeira, com forte caráter educacional, que invocavam valores patrióticos e moralistas.

Em 1886, Júlia Lopes de Almeida e Adelina Lopes Vieira publicam Contos infantis com forte influência do estilo dos escritores europeus. Em 1919, o professor Tales Castanho de Andrade escreveu Saudade, com temática rural, exaltando a vida no campo.

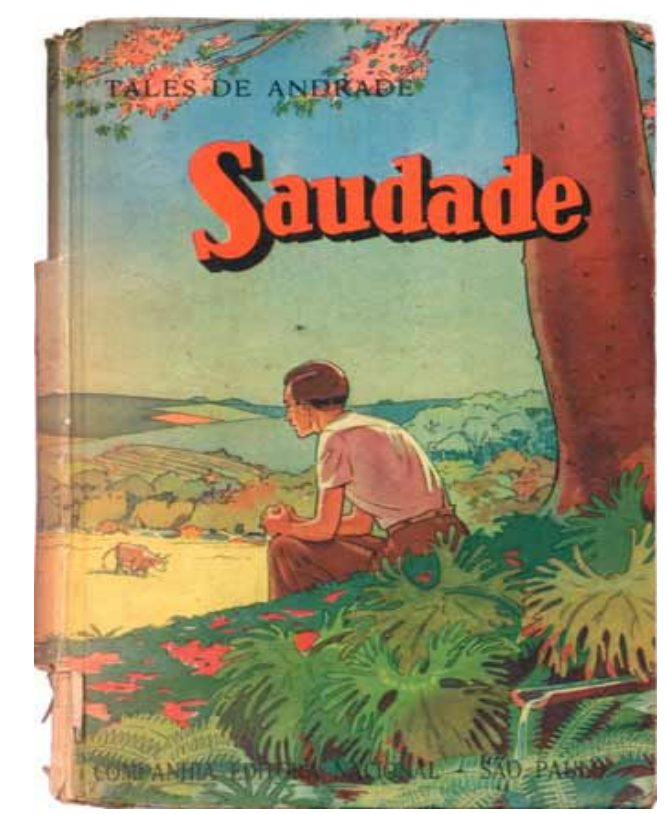

Ilustração 6. ANDRADE. Tales Castanho de. Saudade. 1919.

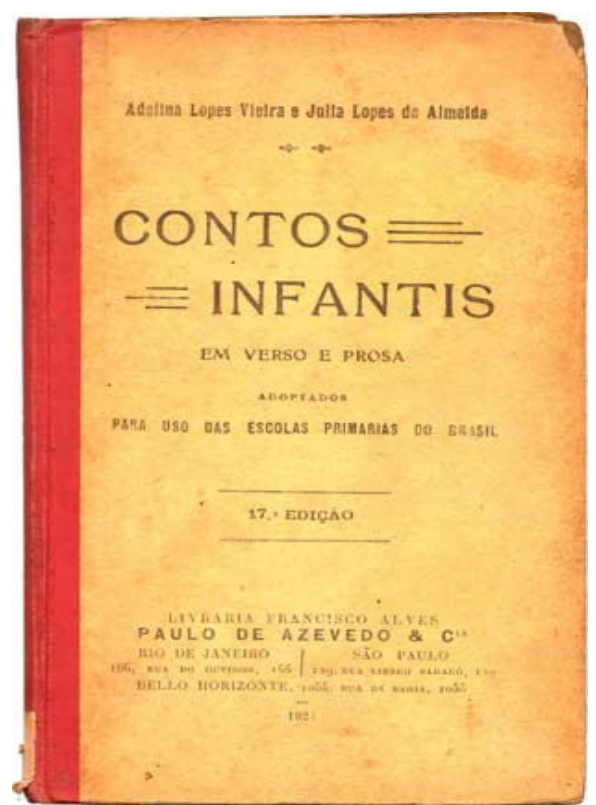

Ilustração 7. ALMEIDA, Júlia Lopes; VIEIRA, Adelina Lopes. Contos infantis. 1886. 
A convite da Casa Alves \& Companhia, Olavo Bilac escreve, em 1904, um livro destinado ao público infantil escolar com o título Poesias infantis. Essa obra foi reeditada inúmeras vezes por ter sido adotada nas escolas brasileiras.

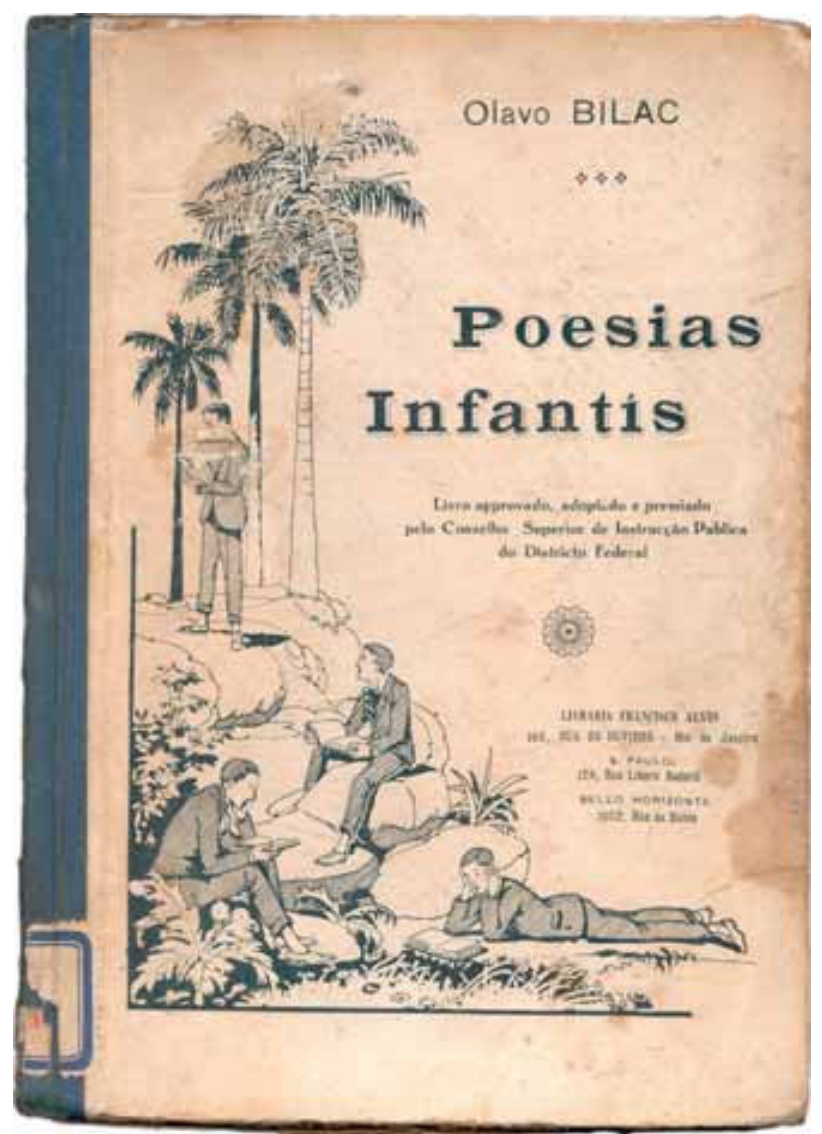

Ilustração 8. BILAC, Olavo. Poesias Infantis. 1904.

Em 1905, o mercado editorial lança a revista infantil O Tico-Tico, inspirada na revista francesa La Semaine de Suzette, com uma tiragem de 21.000 exemplares. O sucesso e sua longevidade - ela foi publicada até meados da década de 1960 - se devem, provavelmente, ao fato de a revista tornar populares alguns personagens do imaginário infantil, por meio de contos regionais, lendas e cantigas populares. Vale salientar que essa revista foi a primeira a publicar histórias em quadrinhos. Em 2005, a Biblioteca Nacional do Rio de Janeiro fez uma exposição comemorativa dos 100 anos de lançamento da revista. 


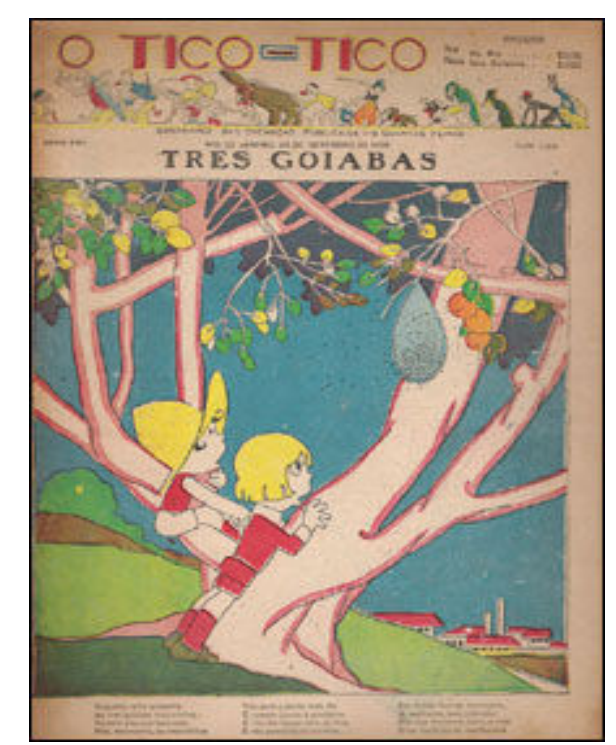

Ilustração 9. Revista O Tico-Tico.

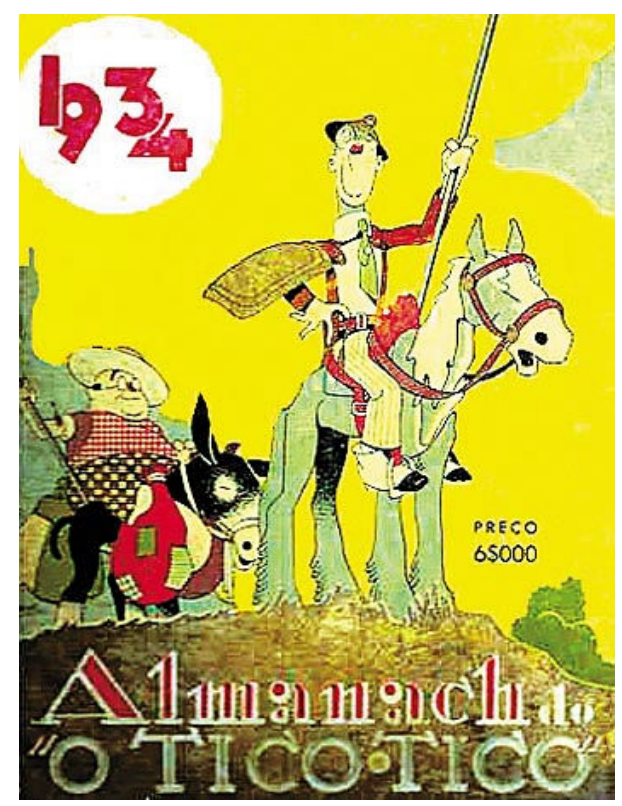

Ilustração 11. Revista O Tico-Tico. 1934.

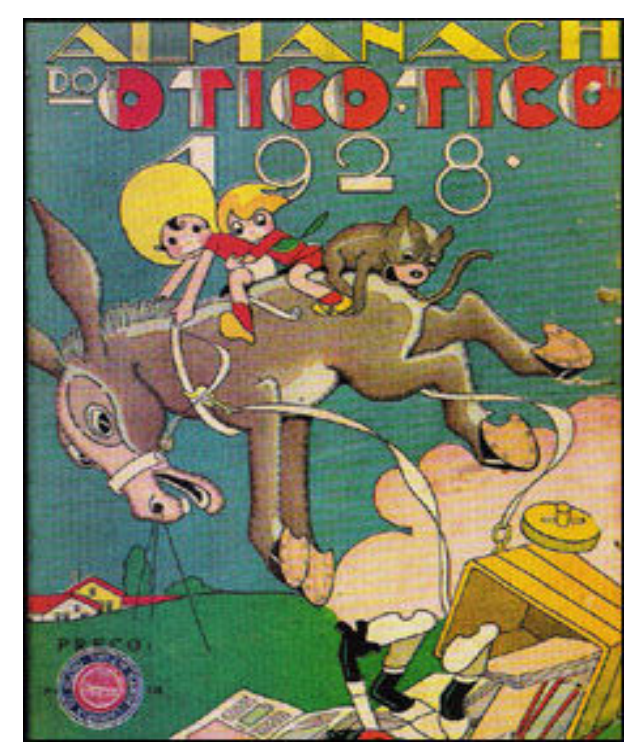

Ilustração 10. Revista O Tico-Tico. 1928.

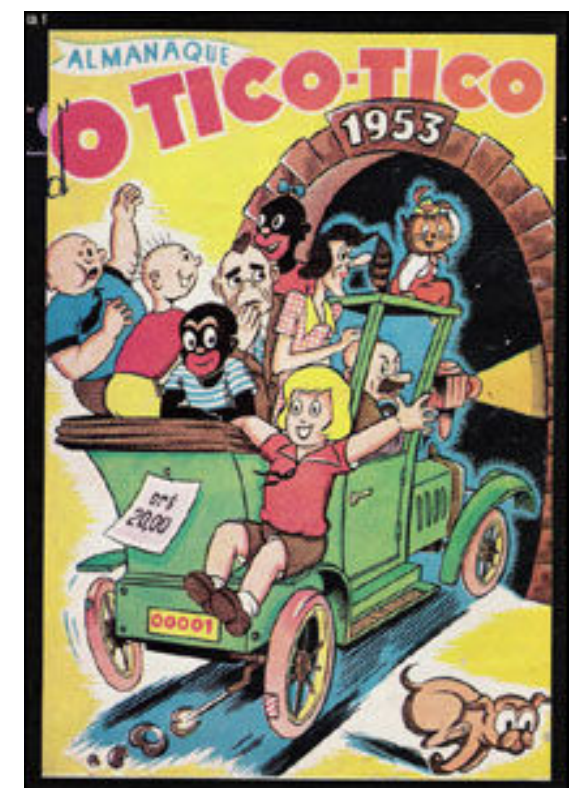

Ilustração 12. Revista O Tico-Tico. 1953

Um marco acontece no cenário da literatura destinada às crianças quando, em 1920, Monteiro Lobato lança $A$ menina do narizinho arrebitado, sua primeira obra destinada a este público. Com uma narrativa original, o autor rompe com o modelo-cópia da literatura europeia ao resgatar os personagens do folclore brasileiro, transcrevendo, como poucos, o cotidiano rural tão peculiar da nossa cultura.

Dotado de uma visão mercadológica, o escritor teve a preocupação estética ao contratar o ilustrador Lemmo Lemmi, conhecido como Voltolino, para fazer a capa cartonada e os desenhos do miolo do livro. No 
ano seguinte, distribui, gratuitamente, 500 exemplares para escolas públicas, permitindo um maior acesso das crianças à obra. A edição escolar contém mais histórias e pequenas mudanças gráficas. O êxito editorial fez com que o autor lançasse mais títulos no mercado, como Fábulas de Narizinho (1921), O Saci ${ }^{5}$ (1921), O Marquês de Rabicó (1922), A Caçada da Onça (1924) e O Noivado de Narizinho (1924).

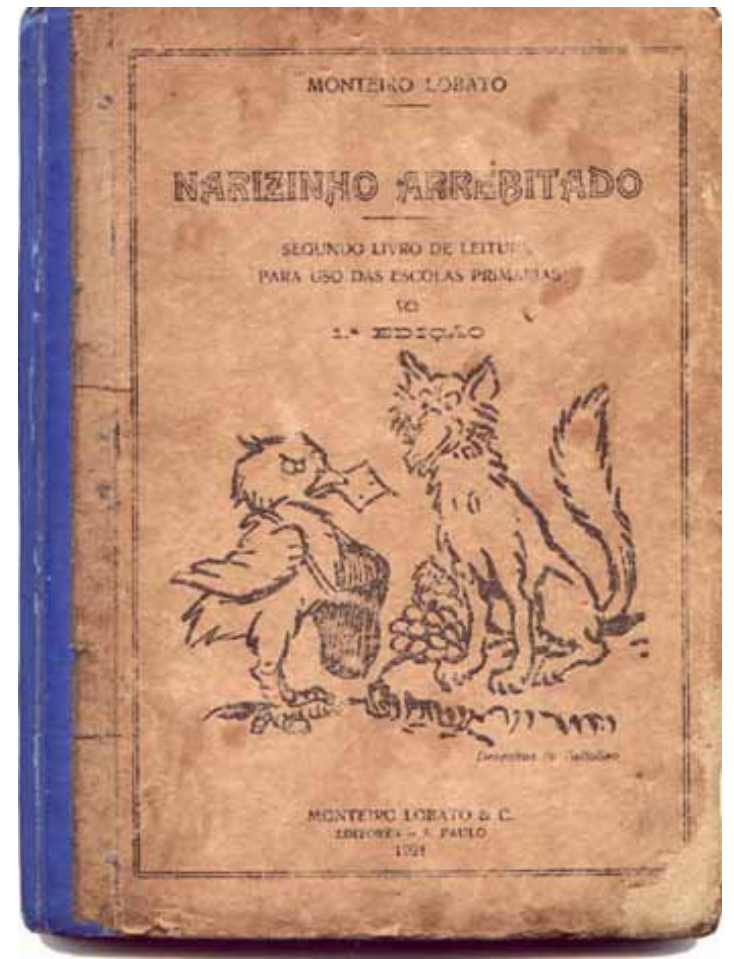

Ilustração 13. LOBATO, Monteiro. Narizinho arrebitado. São Paulo: Monteiro Lobato e Cia, 1921.

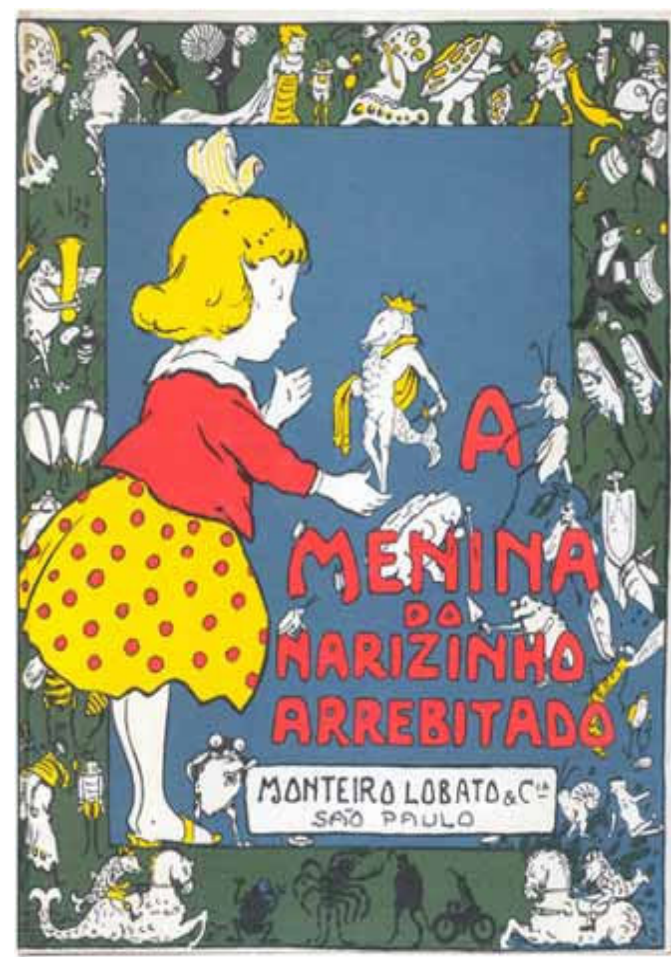

Ilustração 14. LOBATO, Monteiro. A menina do narizinho arrebitado. São Paulo: Monteiro Lobato e Cia, 1920.

Entretanto, antes mesmo do sucesso com a turma do Sítio do Picapau-Amarelo, o escritor percebeu o carisma que os personagens rurais e simples exerciam sobre o público. Em 1918, Lobato lança Urupês, com ilustração (capa) de J. Wasth Rodrigues, contendo 14 contos que descrevem o cotidiano e crendices do caboclo brasileiro. O último conto, intitulado Urupês, descreve um homem do campo chamado Jeca Tatu. Tal

5 O personagem do folclore brasileiro sempre despertou um grande interesse em Monteiro Lobato. O escritor passou a pesquisar sobre ele, realizando uma enquete, pelo jornal "O Estado de São Paulo", que originou a obra O Saci Pererê: resultado de um inquérito, publicada em 1918. 
personagem encanta os leitores e, com tamanha popularidade, o caipira se torna o personagem principal de um livro publicado no ano seguinte.

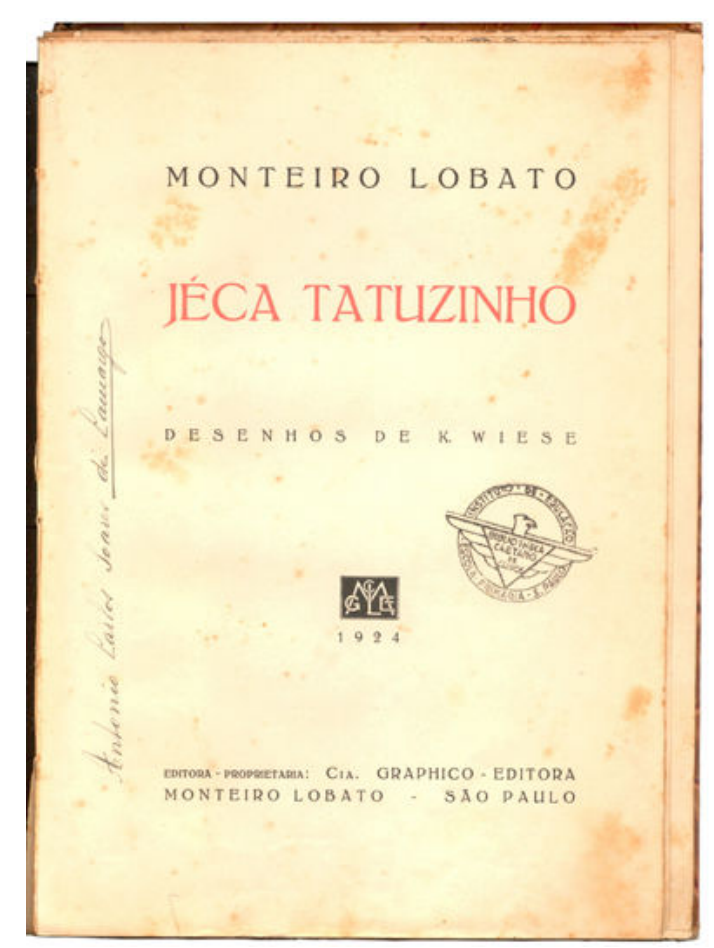

Ilustração 15. LOBATO, Monteiro. Jeca tatuzinho. São Paulo: Monteiro Lobato, 1924.

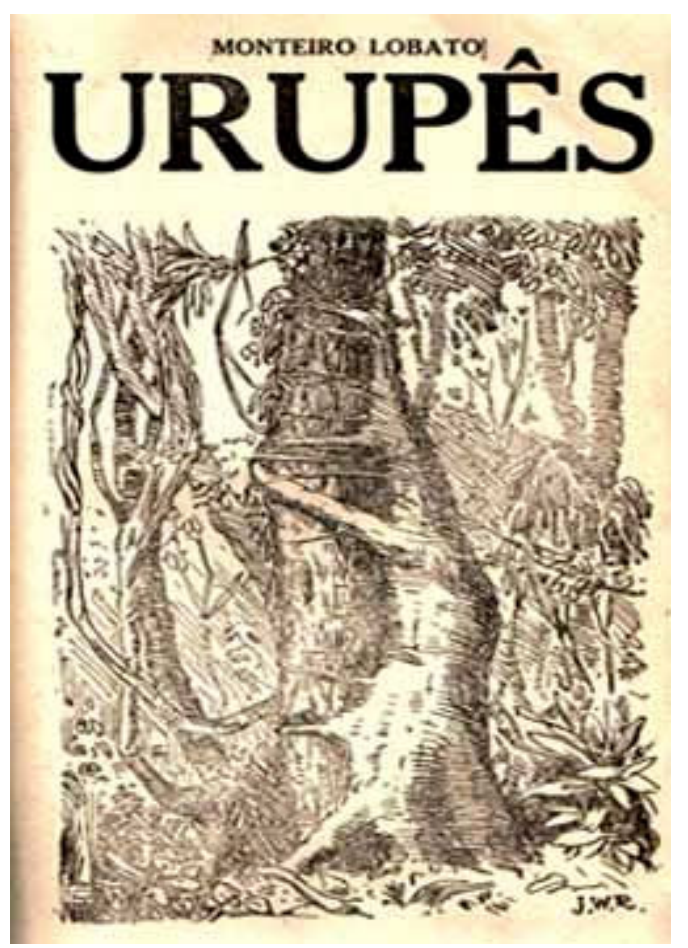

Ilustração 16. LOBATO, Monteiro. Urupês. São Paulo: Monteiro Lobato, 1918.

A ruptura que Lobato provoca no contexto da literatura infantil ultrapassa as questões ideológicas. Ele cria uma personagem que representa as crianças: a serelepe e tagarela Emília, a boneca de pano da Narizinho. Cheia de opinião e de gostos, a bonequinha diz o que pensa e enfrenta verbalmente os adultos, sem medo de ser castigada ou censurada. Ela é a voz da criança acuada sob uma educação rigorosa e moralista.

Apesar dos grandes sucessos de Lobato em décadas anteriores, até o início da década de 1980, a produção de livros infantis é insipiente. Observa-se, de forma tímida e local, alguns progressos como, nos anos 40, a expansão da literatura em quadrinhos e, na década de 1950, a apresentação das primeiras peças de teatro infantil.

Mesmo diante de um mercado editorial amador, com parca produção nacional e infra-estrutura obsoleta, a Câmara Brasileira do Livro cria, em 
1959, o Prêmio Jabuti, valorizando os escritores brasileiros e estimulando a produção de livros e todos os setores envolvidos na produção. Neste mesmo ano, o escritor Renato Sêneca Fleury ganha o prêmio na categoria Literatura Infantil, com a obra Aventuras na Roca. Mas até 1995 (Cf. Anexo C) a categoria Ilustração era generalizada. Somente no ano seguinte foi incluída a categoria "Ilustração para Livros Infantil e Juvenil". O Jabuti é hoje a mais tradicional e importante premiação literária no Brasil, com 21 categorias em 2009.

Em 1968 é criada a Fundação Nacional do Livro Infantil e Juvenil (FNLIJ), tendo como meta divulgar obras e autores que escrevem para crianças e adolescentes, estimulando a leitura. Mas só em 1974 a instituição cria a premiação anual "O Melhor para Criança", estimulando, assim, a criação de obras originais e locais (Cf. Anexo D). Acompanhando o lento processo de modernização do parque gráfico, o aquecimento do mercado editorial e o crescimento de consumidores, somente em 1981 a categoria Imagem foi incluída na premiação. Em 1993, foi inserida a categoria "Ilustrador Revelação". No ano seguinte, mais uma categoria foi criada, a de "Melhor Ilustração".

\begin{abstract}
Em um mercado tão restrito, o "público alvo" deixa de ser a criança (ou os pais) enquanto agente da escolha e passar a ser a escola. O livro de literatura passa a ser material paradidático, totalmente dependente do sistema educacional. Ou seja, um produto feito para o público infantil é selecionado e escolhido por adultos (LINS, 2002, p. 43).
\end{abstract}

Se tomarmos o contexto histórico como ponto de comparação, observaremos que a abertura política nos anos 80 marca o terceiro momento da literatura infantil, que vai até meados da década de 1990 . O fim da ditadura militar permitiu a liberdade de expressão e, com ela, a ousadia para experimentar novas formas de comunicação verbal e visual. Neste período inicia-se 0 apelo à visualidade. Temas-tabuss são confrontados e as questões do cotidiano são descritas e debatidas. 
A última etapa, a contemporânea, que corresponde ao final do século XX até os dias de hoje, mostra um mercado maduro, com leitores fiéis e uma rica produção de livros infantis, tanto em variedade quanto em temas. As novas tecnologias multiplicam as linguagens e barateiam o produto final. Segundo a CBL (Câmara Brasileiro do Livro), em 1990, o país movimentou $\mathrm{R} \$ \mathbf{9 0 1 . 5 0 3 . 6 8 7 , 0 0}$ na comercialização de 22.479 títulos. Em 2000, o movimento do setor ultrapassou R $\$ 2$ bilhões, com 45.111 obras disponibilizadas no mercado livreiro.

Conscientes de que o livro é um produto industrial, todos os setores e profissionais envolvidos na sua elaboração vêm trabalhando para "responder aos anseios estéticos de todas as partes envolvidas, além de atender às expectativas emocionais e psicológicas do público leitor que escapam da teoria e de toda a metodologia de trabalho" (LINS, 2002, p. 44).

Diante deste mapa atual, vemos a literatura infantil em crescimento, com um sólido espaço conquistado no mercado editorial e no pequeno leitor, que consegue estabelecer uma relação lúdica e afetiva com essa literatura.

Esse amadurecimento colabora com a ruptura de pré-conceitos e tira a literatura infantil da marginalidade, na qual viveu até pouco tempo. Ao incluirmos e estudarmos esse gênero no universo acadêmico, possibilitamos a todos um enriquecimento cultural e a liberdade de expressão.

Como se a menoridade de seu público a contagiasse, a literatura infantil costuma ser encarada como produção cultural inferior. Por outro lado, a frequência com que autores com trânsito livre na literatura não-infantil vêm se dedicando à escrita de textos para crianças, somada à progressiva importância que a produção literária infantil tem assumido em termos de mercado e de oportunidade para a profissionalização do escritor, não deixam margens para dúvidas (LAJOLO; ZILBERMAN, 2006, p. 11). 
O que define a qualidade da obra não é o seu gênero e a quem ela se destina, mas a sua riqueza linguística. A princípio, as literaturas infantis e as não-infantis "compartilham a mesma natureza de produção simbólica que faz da linguagem sua matéria-prima e, dos livros, seu veículo preferencial" (LAJOLO; ZILBERMAN, 2006, p. 10-11). 


\subsection{A literatura e a ilustração nos livros infanto-juvenil na Europa e nos Estados Unidos}

O escritor e poeta francês Charles Perrault (1628-1703) é considerado o pai da literatura infantil ao contribuir na elaboração de um novo gênero, o de contos de fada. Ao coletar histórias orais populares, o escritor lançou, em 1697, Histórias ou contos do tempo passado com moralidade: contos da mamãe gansa, contendo vários contos que se tornaram clássicos e atravessaram épocas, como Chapeuzinho vermelho, A bela adormecida, Cinderela, O pequeno polegar, Barba azul, O gato de botas, Pele de asno. Ao final de cada história, ele apresentava uma pequena poesia moralista.

Outro francês que trouxe grande contribuição para a história da literatura infantil foi Jean de La Fontaine (1621-1695) ao escrever, em 1668, Fábulas escolhidas - contendo 124 narrativas - para entreter o filho do rei da França, Luís XIV. As histórias traziam animais humanizados (falavam, sentiam, confabulavam) e um conteúdo moralizador. Sua linguagem simples e direta tornou a obra popular rapidamente, eternizando histórias como "A Lebre e a Tartaruga", "O Homem", "O Menino e a Mula" e "O Leão e o Rato". Fontaine é considerado o "pai da fábula moderna".

Contemporâneo deles, o inglês Sir. Roger L'Estrange (1616-1704), traduziu, em 1692, clássicos gregos e latinos, como as fábulas de Esopo e textos de Sêneca, o Jovem. As fábulas resultaram num trabalho panfletário, com uma forte carga política conservadora. Logicamente o público alvo não era a criança, mas, em 1722, o escritor Samuel Croxall (1688-1752), publicou esse material, diluindo, porém, as questões ideológicas e adaptando a obra para o universo infantil.

No início do século XIX, dois irmãos alemães, Jacob (1785-1863) e Wilhelm Grimm (1786-1859), decidiram estudar história e linguística. Nesse percurso, registraram várias histórias de tradição oral, como sagas e contos, narradas pelos povos de várias nações. Como resultado dessa 
pesquisa, os irmãos lançaram, em 1810, sua primeira compilação, contendo 51 histórias. Dois anos mais tarde, publicam a coletânea "Contos da criança e do lar". Três anos depois, sai o segundo volume dessa coletânea e, em 1822, o terceiro volume. Somente em 1825 os irmãos juntam os três volumes transformando-os em um único livro - com ilustrações feitas pelo irmão deles, Ludwig Emil Grimm - que logo se tornou um "cânone das gerações seguintes" (POWERS, 2008, p. 30). Eles tornaram populares histórias como "Cinderela", "Branca de Neve", "João e Maria", "Rapunzel" etc.

Muitas das histórias narradas pelos irmãos Grimm são sangrentas, um tanto "pesadas" para os dias de hoje, mas as adaptações feitas ao longo dos anos diluíram essa carga de medo e terror.

Outro importante escritor foi o dinamarquês Hans Christian Andersen (1808-1875) com seus contos de fada que, assim como os irmãos Grimm, o tornaram popular. Autor de histórias consagradas que se caracterizavam pela crueldade psicológica, como "O patinho feio", "O soldadinho de chumbo", "A pequena sereia", "A roupa nova do rei" e a "A princesa e a ervilha", "Rumpelstiltskin", entre outras.

Pela sua colaboração à literatura infantil, a data de aniversário de Andersen, 2 de abril, tornou-se o "Dia Internacional do Livro InfantoJuvenil". E o mais importante prêmio internacional do gênero, dada pela International Board on Books for Young People (IBBY), tem o seu nome.

Tendo feito um breve panorama dos principais escritores e dos contos que se tornaram atemporais, seguiremos pela cronologia, facilitando o olhar sobre a evolução dessa literatura através do tempo.

No século XVI surgem os chapbooks, livros de bolso feitos com material simples, capa fixa e pouco durável, que logo se popularizaram pelo preço baixo e pela praticidade de uso. Com temas variados, como os contos folclóricos e mágicos, caíram no gosto, e nas mãos, das crianças.

Com esse gênero surge a capa de livro ilustrada associada às crianças, permanecendo "uma constante na edição de obras de literatura 
infantil, sendo depois imitada pela indústria de livros" (POWERS, 2008, p. 10).

O ano de 1744 traz uma grande mudança no cenário editorial. O livreiro britânico John Newbery, especializado em livros para crianças, edita $A$ little pretty pocket-book com uma encadernação banhada a ouro, dando origem ao livro-presente.

No século seguinte, mais mudanças: os livros passam a ser encadernados com tecido, permitindo inserir elementos decorativos. Paralelamente a isso, entra em cena a impressão com cores e um estilo mais descontraído nas capas. Um bom exemplo é a obra alemã Struwwelpeter ${ }^{6}$, publicada em 1848, na Inglaterra, que influenciou o mercado por seu tamanho grande, fora do padrão editorial da época, e estilo despretensioso, acrescido de uma paródia grotesca, como a extirpação dos dedos do personagem principal por desobedecer a mãe, cheia de advertências e castigos.

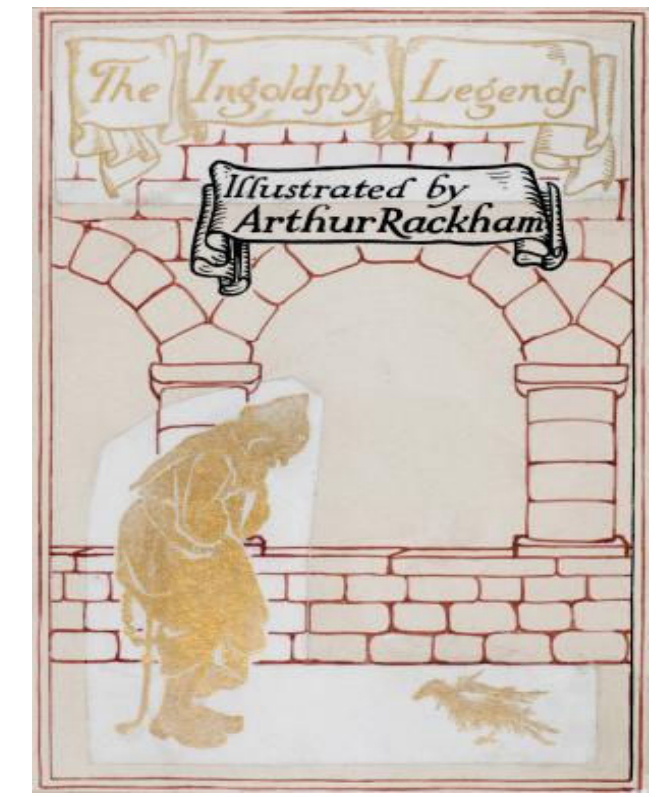

Ilustração 17. BARHAM, Richard Harris. The Ingoldsby legends. 1898. Impressão em quadricromia.

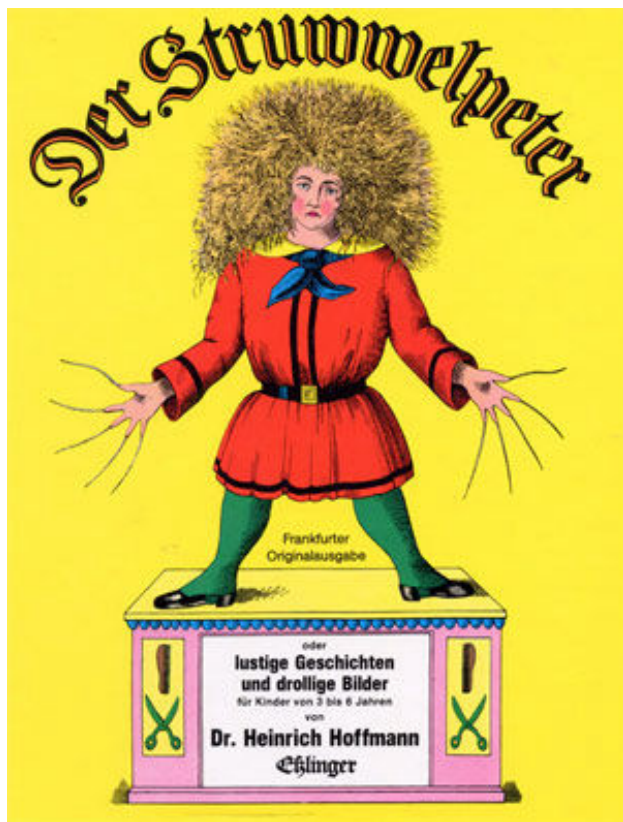

Ilustração 18. HOFFMANN, Dr. Heirich. The English Struwwelpeter. Londres.

\footnotetext{
${ }^{6}$ No Brasil, este livro foi publicado em 1942 pela editora Melhoramentos, recebendo o nome de João Felpudo, mas manteve na capa uma ilustração muito parecida com a original.
} 
Na segunda metade do século XIX, os livros passam a receber um "tratamento tipográfico de letreiros, com maiúsculas sombreadas em negrito contra fundos de uma cor só" (POWERS, 2008, p. 13). Nesse período, os ilustradores começaram a sair do anonimato e passaram a assinar seus trabalhos, como Arthur Rackham.

Embora a ilustração esteja historicamente ligada ao universo infantil, o estilo e os desenhos eram sérios ou abstratos, mais próximos ao mundo dos adultos, pois essa era a estética da época.

No final do século XIX ocorre uma divisão estilística na forma física de se fazer os livros, entre contenção - capas simples, com letra e desenhos nostálgicos -, como se pode observar na capa do livro $A B C \mathrm{Na}$ Alphabet, de Arthur Gaskin, de 1895, e expressão, com o uso de cores vibrantes, seguindo a vanguarda da época com recorrência a art nouveau ${ }^{7}$ e ao movimento art and crafts. Os livros da coleção Bunbury, alguns escritos por Grace Rhys, apresentam essas características de forma exemplar.

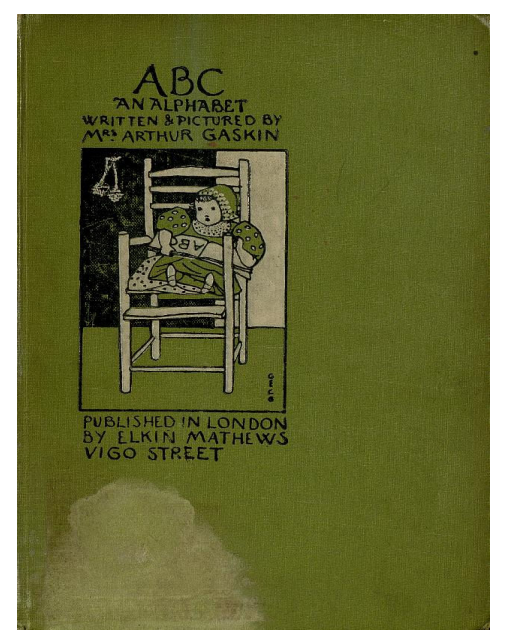

Ilustração 19. GASKIN, Sra. Arthur. ABC: An Alphabet. Londres: Eikin Mathews, 1895.

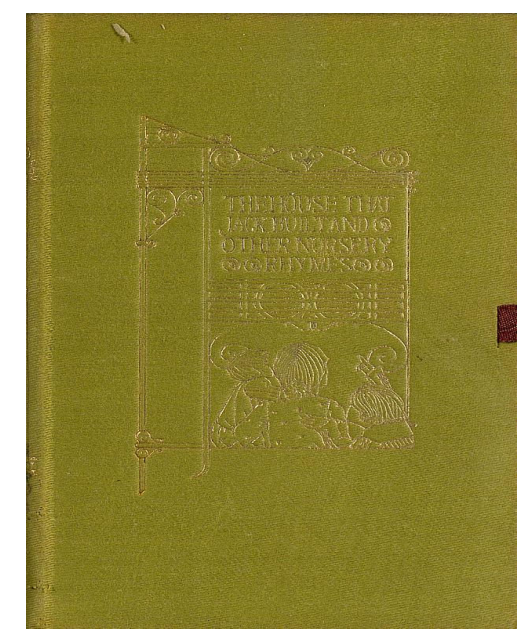

Ilustração 20. RHYS, Grace. The house that Jack built and other nursery rhymes. Londres: J. M. Dent \& Co, 1895.

\footnotetext{
7 A Art Nouveau é um estilo estético das artes com grande abrangência (design, arquitetura e artes plásticas). Surgido no final do século XIX, na França, teve grande atuação na Belle Époque e estava relacionado ao movimento Arts and Crafts. Suas principais características são a utilização de formas orgânicas e a valorização do trabalho artesanal. O movimento Arts and Crafts, de origem inglesa, tinha uma posição mais politizada, se opondo ao industrialismo, ressaltando a produção artesanal e defendendo o fim da distinção entre a artesão e a artista.
} 
O movimento arts and crafts havia gerado, nos dois lados do Atlântico, o sentimento de que o livro era um objeto coeso. Isso implicava que o projeto deveria apresentar unidade em todos os seus elementos, desde o tamanho da página e layout, até a escolha de papel, tipografia, ilustração e encadernação [...]. Todas as sobrecapas eram duvidosas, pois não faziam parte fisicamente do livro (POWERS, 2008, p. 42).

Paralelamente a essas mudanças estéticas no universo das artes plásticas e, por que não dizer, do design, havia na Europa, principalmente na Inglaterra, uma preocupação social em proteger a infância da dura realidade, resgatando a inocência através da cultura, como o teatro e a literatura. Daí o sucesso de Peter $\operatorname{Pan}^{8}$, de James Matthew Barrie, ao oferecer às crianças um mundo lúdico, cheio de aventuras, magias, alegrias e esperança.

Neste período, observa-se o talento extraordinário dos escritores ingleses ao usar a excentricidade narrativa para encantar o público infantil, formando seguidores que veem em obras com essa característica a entrada em um mundo de fantasias e magias. Em 1865, Lewis Carroll (1832-1898) - na verdade, Charles Lutwidge Dodgson ${ }^{9}$ - lança As aventuras de Alice no país das maravilhas, provocando grande impacto no mercado literário e estranhamento no leitor.

Seguindo essa linha, temos um representante da literatura nonsense que dialogava com as crianças através de seus poemas carregados de senso de humor. Edward Lear (1812-1888) conciliou seu absurdo literário com ilustrações inteligentes. Ele foi o responsável pela popularidade do gênero limeliks ${ }^{10}$, com poemas de cinco linhas com rima na primeira, terceira e quinta linhas.

\footnotetext{
8 Peter Pan era um dos personagens do livro The Little White Bird (1902). O sucesso da obra a transformou numa peça de teatro intitulada Peter Pan or The Boy Who Wouldn't Grow, em 1904. Somente em 1906 o autor lançou Peter Pan in Kensington Gardens.

9 Charles Lutwidge Dodgson foi um respeitado matemático do século XIX, tendo publicado vários trabalhos sobre lógica. Como literato, adotou o nome Lewis Carroll. Também atuou como fotógrafo.

${ }^{10}$ Limelicks são poesias com uma única estrofe, com cinco versos. Surgiram na Irlanda, no século XVIII, mas tornaram-se populares no século seguinte pelas mãos do escritor
} 

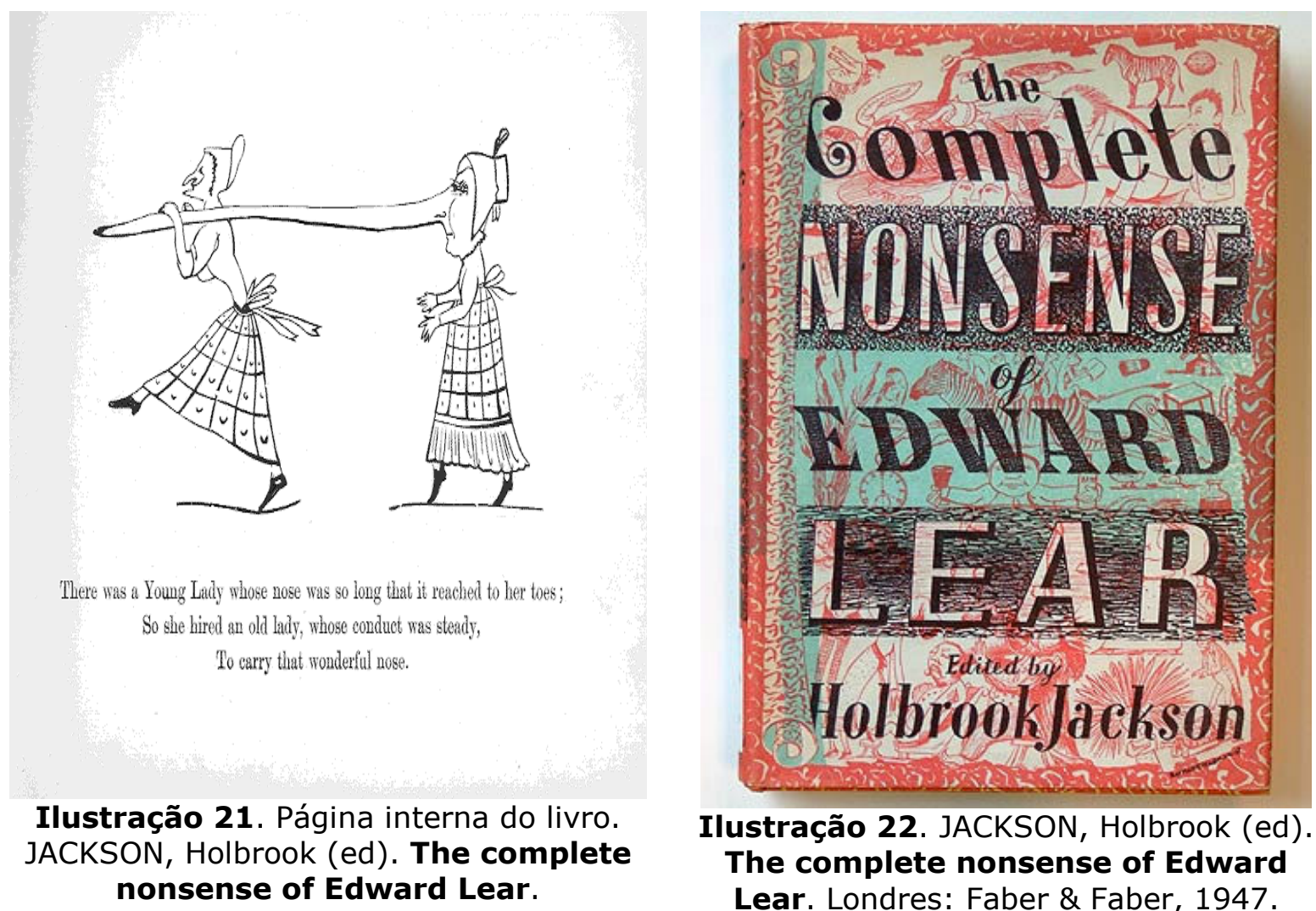

Ilustração 22. JACKSON, Holbrook (ed). The complete nonsense of Edward Lear. Londres: Faber \& Faber, 1947.

A chegada do século $X X$ trouxe mudanças significativas para os livros, tanto os destinados para as crianças quanto os para os adultos. Com a urbanização e o crescimento das cidades, o fortalecimento da classe média e o acesso a bens de consumo da classe operária aqueceram o mercado editorial, gerando competitividade e o amadurecimento do setor. Cada editora procurou encontrar saídas editoriais e projetos gráficos diferentes para seduzir os consumidores.

Os livreiros se conscientizaram de que um bom livro devia tratar de forma igual o texto verbal e o texto visual, vendo-os como um todo, com coerência entre os dois e senso de totalidade. Para torná-los atrativos, eles investiram em novas técnicas de impressão alternativas, dando um caráter estético à obra.

A Europa vivia um período nostálgico e confiante. A nostalgia é concreta: os bairros residenciais foram projetados em estilo clássico, com um pequeno quintal florido, remetendo à vida bucólica de outrora. E assim

nonsense, Edward Leart. Elas se caracterizam pelo conteúdo cômico e, algumas vezes, intencionalmente obscenos. 
eram as ilustrações dos livros para crianças.

Do outro lado do Atlântico, na década de 1920, mais precisamente nos Estados Unidos, todos os setores envolvidos com a produção e distribuição dos livros infantis se uniram e criaram uma rede de comunicação com o objetivo de profissionalizar e tornar dinâmica e eficaz essa área. Com essa estrutura, os setores responsáveis criam, em 1923, a "Medalha Newbery", dada aos melhores livros destinados ao público infantil. Quinze anos mais tarde criam a "Medalha Caldecott", premiando os ilustradores.

A partir da segunda década do século $X X$, os projetos gráficos para livros infantis sofrem alterações constantes, influenciados pelas estéticas e movimentos de época. Ocorrem também mudanças físicas no livro, que tem suas capas duras substituídas por brochuras e um "emagrecimento" no número de páginas, como forma de redução de custos, principalmente durante a Segunda Guerra Mundial.

Apesar de ser um período de escassez, surgiram obras criativas e originais, como o livro A Book of Rigmaroles or Jingle Rhymes (1945), da artista plástica inglesa Enid Marx, feito com xilogravura e tendo como tema a arte popular.

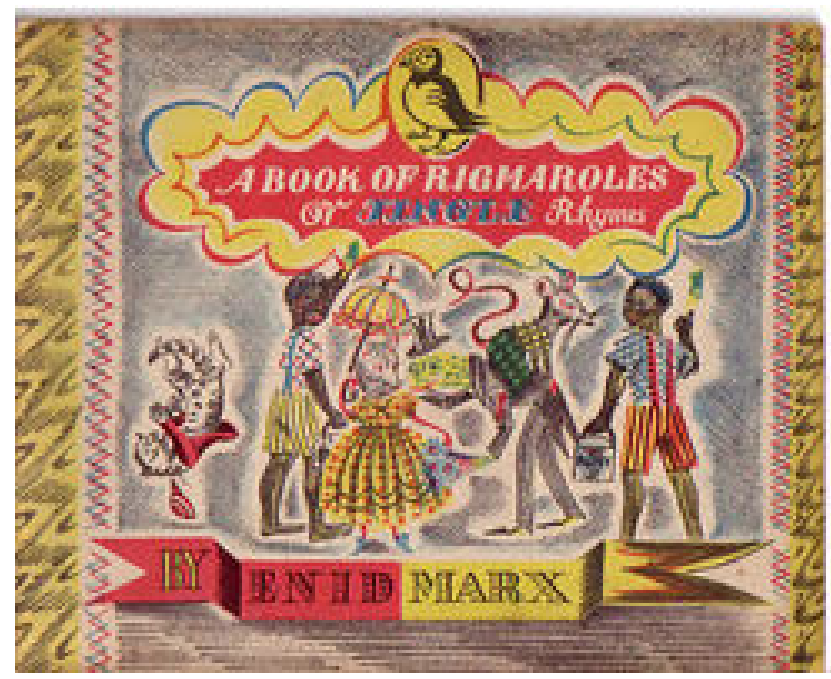

Ilustração 23. Com designer têxtil, o livro aborda a cultura popular. MARX, Enid. A book of rigmarols or Jingle Rhymes.

Harmondsworth: Penguin Book, 1945. 
Com o final da guerra, buscou-se recuperar a alegria e a magia do povo promovidas pelos setores de entretenimento. Na literatura resgatouse a sensibilidade e o afeto, com a inserção de temas-tabus - como medo, separação dos pais, discriminação - compartilhados com as crianças. Um exemplo desse fato é encontrado na obra Tom 's Midnight Garden (1958), da escritora Philippa Pearce em que esses temas são tratados.

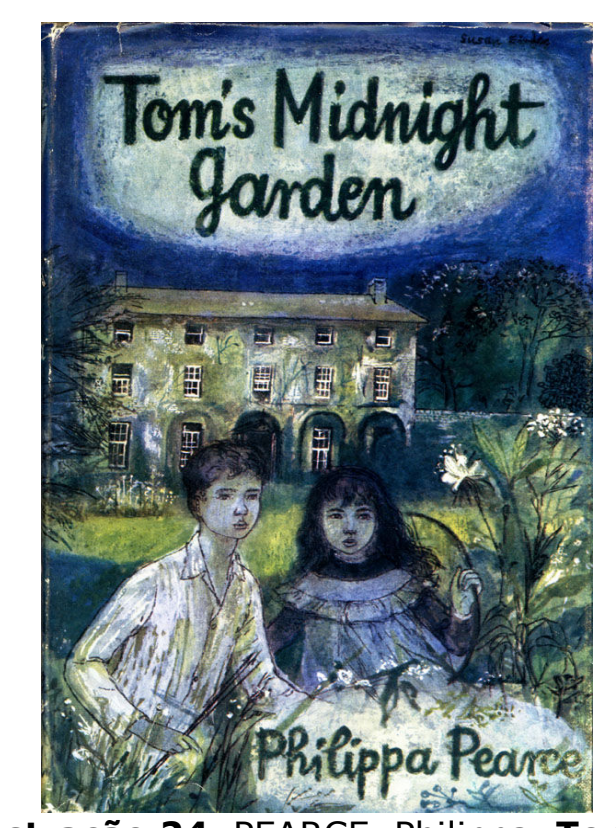

Ilustração 24. PEARCE, Philippa. Tom 's Midnight Garden. Londres: Oxford University Press, 1958.

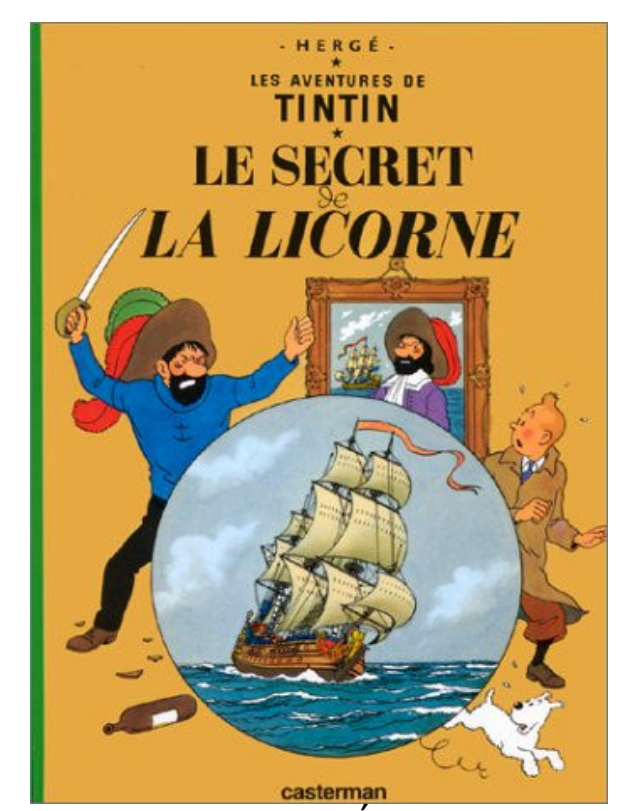

Ilustração 25. HERGÉ [REMI, George]. Les aventures de Tintin: le secret $d$ la licorne. 1959.

Por outro lado, há o personagem Tintim, do quadrinista belga Hergé, que "não tem vida emocional; ele parece sentir por meio daqueles que o cercam, como seu cachorro Milu e seu companheiro, capitão Haddock" (POWERS, 2008, p. 71).

A década de 1960 enterra a delicadeza e o romantismo, produzindo obras psicodélicas, com uma explosão de cores e formas. Contra o conservadorismo da sociedade, os autores dessa década adotam o pensamento de que "ninguém precisava realmente crescer" (POWERS, 2008 , p. 93), com o apoio de artistas e escritores que transcrevem essa rebeldia através de movimentos artísticos e literários. Um período rico em oferta de livros criativos e inteligentes. Um bom exemplo desse período é o trabalho do ilustrador Brian Wildsmith, com suas capas pulsantes e 
eletrizantes, com fortes características da pintura expressionista abstrata. Se os adultos ficavam desconcertados com suas obras, as crianças ficavam fascinadas com tantas cores, com tanta vida. Seu livro $A B C$, de 1962, recebeu a "Medalha Kate Greenaway" pelas belas ilustrações.

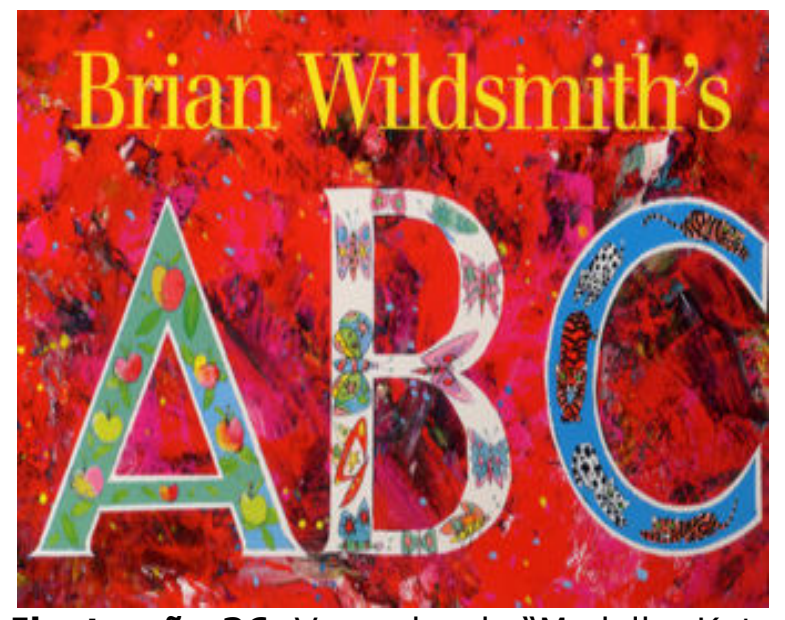

Ilustração 26. Vencedor da "Medalha Kate Greenaway". WILDSMITH'S, Brian. ABC. Londres: Oxford University Press, 1962.

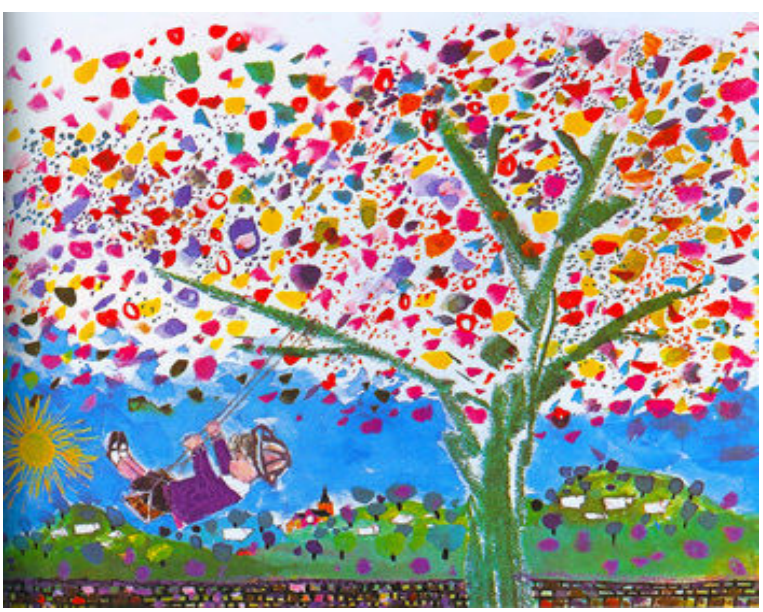

Ilustração 27. STEVENSON, Robert Louis (autor); WILDSMITH'S, Brian (ilustrador). A Child's Garden of Verses.

Em meados dos anos de 1970, o artesanato volta a pontuar e a se fazer presente em obras premiadas como, por exemplo, o conto africano Why Mosquitoes Buzz in People's Ears (1975), de Verna Aardema, ilustrado por Leo e Diane Dillon, vencedores do prêmio "Medalha Caldecott". Os desenhos foram feitos com aerógrafo de aquarela, tintas pastel e nanquim.

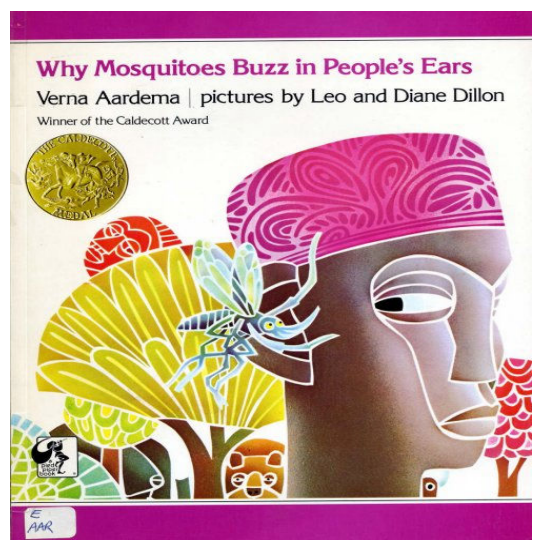

Ilustração 28. AARDEMA, Verna (autora); DILLON, Leo e Diane (ilustradores). Why mosquitoes buzz in people's ears. New York: Dail Books for Readers, 1975. 
Os ilustradores desse período se viam como artistas expressando sua arte através do veículo livro, e não como desenhistas. Também foi um período de rebeldia em que as novas gerações criticavam abertamente os governos e a sociedade. Tal discurso estava presente em todas as formas de comunicação, inclusive na literatura infantil. Muitos escritores usaram esse canal para expressar suas posições políticas e ideológicas, mascaradas em textos para crianças. Em The Mouse and his Child, de 1967, o escritor Russel Hoban inclui uma paródia de Samuel Beckett dialogando com outros gêneros. Essa ponte, que estreitou épocas e cruzou estilos e movimentos literários, se chama Pós-modernismo, uma negação às estruturas e pensamentos do presente de então.

A expansão do ensino infantil e o crescente número de crianças alfabetizadas fortalecem a indústria cultural nas décadas de 1980 e 1990. O livro infantil abocanha um mercado significativo e promissor. As estratégias para seduzir esse consumidor mirim abrem um enorme leque de técnicas, estilos e modismos.

Os problemas emocionais na infância - como medos, perdas e dores -, são escritos e falados de forma mais natural e realista, abrindo espaço para a própria criança se manifestar e se expressar. Outros temas-tabus são inseridos, diluindo, assim, estereótipos, preconceitos e até mesmo pensamentos ingênuos, como acreditar que criança não tem maldade ou não é capaz de um ato de crueldade.

Nos dias atuais, podemos observar uma variedade enorme de temas, de projetos gráficos e de estilos. Essa democracia editorial permite à criança o exercício de escolha e sua autonomia. O mais importante é que esses livros instiguem as crianças a pensar e as atraia para o mundo das letras e das artes. "Na era digital, uma das vantagens da obra física é sua qualidade tátil. Diferentemente de observar uma tela, vira-se uma página com a mão - e livros se prestam a várias formas de manuseio e manipulação" (POWERS, 2008, p. 134). 
CAPÍTULO II - ANÁLISE DO CORPUS 


\title{
2.1. PAIXÕES
}

\subsubsection{O universo passional de Marina Colasanti, em A moça tecelã}

\begin{abstract}
"As palavras são tecidas a partir de uma multidão de fios ideológicos e servem de trama a todas as relações sociais em todos os domínios."
\end{abstract}

Mikhail Bakhtin ${ }^{11}$

Estabelecemos como objeto de análise o livro $A$ moça tecelã ${ }^{12}$, de Marina Colasanti, publicado em 2004 pela editora Global. Optamos por restringir a análise ao texto verbal, excluindo o visual e sua relação sincrética com o texto escrito para dar destaque à significação das paixões, que molda o percurso do sujeito. Desse modo, por meio das relações modais, nos será possível identificar os efeitos de sentido gerados pelos estados patêmicos.

Dividimos o texto em três partes, determinadas por mudanças tímicas e de estado do sujeito, seguindo a própria narrativa do texto, que mostra uma sequência de estados afetivos de forma gradual e tensiva.

É importante ressaltar que a divisão do texto é apenas metodológica, tendo por objetivo facilitar a análise do conto. Cada uma das partes recebe um "título" relacionado aos estados de junção do sujeito que desencadeiam afetividades. Os sublinhados e negritos são destaques nossos, pois são palavras e frases que evidenciam as mudanças tímicas do sujeito, mudando seu percurso e a narrativa da história.

O conto é narrado em terceira pessoa (enunciação enunciva), criando um simulacro de imparcialidade. Os traços de subjetividade são apagados, criando o efeito de distanciamento, de credibilidade e de

\footnotetext{
${ }^{11}$ BAKHTIN, Mikhail; VOLOCHINOV, V.N.. Marxismo e filosofia da linguagem. $12^{\mathrm{a}}$ ed. São Paulo: Hucitec, 2006, p. 42.

${ }^{12}$ Esse conto também faz parte do livro Doze Reis e a Moça no Labirinto do Vento. Rio de Janeiro: Global, 2000.
} 
veracidade, pois é alguém externo ao conto que está relatando a história. Os verbos estão, predominantemente, no pretérito imperfeito (enunciação enunciva), dando a sensação de inacabamento e de duratividade para as ações. Na categoria de espaço, mantém-se a enunciação enunciva, por meio da instauração de um lugar distante (algures), que é uma característica própria dos contos de fadas. Algumas figuras reforçam e recriam esse universo mítico no texto, tais como: palácio, jardins, carruagens, cavalos, pátios, escadas, torres, criados.

As debreagens, com orientação disjuntiva, criam efeito de sentido de afastamento do sujeito da enunciação, ocorrendo no texto em situações de mudanças de estado e transformações dos sujeitos afetados passionalmente. Com esse mecanismo, "o discurso certamente perde em intensidade, mas ganha em extensão: novos espaços, novos movimentos podem ser explorados, outros actantes podem ser postos em cena" (FONTANILLE, 2007, p. 99).

Ocorre uma debreagem enunciativa de segundo grau de pessoa, quando o homem - que deixa de ser objeto e passa a ser destinador - fala na primeira pessoa (com travessão) para a moça tecelã, criando um efeito de aproximação emocional, gerando relações/estados afetivos por meio da instauração do diálogo. Ainda no campo enunciativo, o tempo verbal passa a ser o pretérito perfeito, com o simulacro de algo acabado, pontual e dinâmico. Apenas o espaço é mantido no campo enuncivo durante toda a narrativa do conto, pois se trata de um espaço do "lá" ou do "não-aqui".

As categorias de tempo e de espaço voltam ao quadro enuncivo apenas nos dois últimos parágrafos do conto, quando a moça restabelece seu estado inicial e o homem, destecido, também retoma sua função de objeto. Há uma retomada da posição inicial, embora esta seja apenas um simulacro. No que diz respeito à questão da aspectualidade, a semiótica tensiva pode ampliar a compreensão do texto ao dar aos tempos verbais um olhar tensivo. Observando com atenção a aspectualidade, podemos depreender do texto o contínuo e o descontínuo, o acabado e o não acabado. Essa abordagem tensiva nos será propícia para uma melhor 
compreensão do texto, ao nos permitir verificar como esse mecanismo aspectual determina e pontua os estados passionais dos sujeitos. Os fenômenos passionais regulam o eixo da intensidade no discurso através da aspectualização. Eles são "os traços aspectuais e rítmicos que caracterizam os tipos passionais" (FONTANILLE; ZILBERBERG, 2001, p. 296). Nesse conto, por exemplo, os verbos no pretérito perfeito, que correspondem à parada da parada, estão relacionados a descontentamentos, em que há o fim de uma espera e o começo de uma falta, como logo veremos durante a análise.

\section{$1^{a}$ parte: Harmonia com o tempo}

Acordava ainda no escuro, como se ouvisse o sol chegando atrás das beiradas da noite. E logo sentava-se ao tear.

Linha clara, para começar o dia. Delicado traço cor da luz, que ela ia passando entre os fios estendidos, enquanto lá fora a claridade da manhã desenhava o horizonte.

Depois lãs mais vivas, quentes lãs iam tecendo hora a hora, em longo tapete que nunca acabava.

Se era forte demais o sol, e no jardim pendiam as pétalas, a moça colocava na lançadeira grossos fios cinzentos do algodão mais felpudo. Em breve, na penumbra trazida pelas nuvens, escolhia um fio de prata, que em pontos longos rebordava sobre 0 tecido. Leve, a chuva vinha cumprimentá-la à janela.

Mas se durante muitos dias o vento e o frio brigavam com as folhas e espantavam os pássaros, bastava a moça tecer com seus belos fios dourados, para que o sol voltasse a acalmar a natureza.

Assim, jogando a lançadeira de um lado para outro e batendo os grandes pentes do tear para frente e para trás, a moça passava os seus dias.

Nada Ihe faltava. Na hora da fome tecia um lindo peixe, com cuidado de escamas. E eis que o peixe estava na mesa, pronto para ser comido. Se sede vinha, suave era a Iã cor de leite que entremeava o tapete. E à noite, depois de lançar seu fio de escuridão, dormia tranquila. Tecer era 
tudo o que fazia. Tecer era tudo o que queria fazer.

Mas, tecendo e tecendo, ela própria trouxe o tempo em que se sentiu sozinha, e pela primeira vez pensou como seria bom ter um marido ao lado. (COLASSANTI, 2004, p. 5-7, grifos nossos).

O texto se inicia com uma conjunção entre a moça tecelã e o tempo, e tudo que está relacionado a ele, como as figuras das estações (chuva, calor), das unidades de tempo (dia, noite), da temperatura (quente, frio) e da cronologia (hora a hora, primeira vez). Ela está em conjunção com todos esses elementos figurativos, compartilhando seus sentimentos e seu saber (o tecer). Os verbos acionam ações vinculadas ao tempo, como: acordava, chegando, ia passando, (nunca) acabava, passava, dormia, mantendo a coerência do texto.

A moça age sempre em harmonia com o tempo, embora interfira nele sutilmente quando, por exemplo, ela desenha a chuva para refrescar as pétalas que sofrem com o forte calor. Outra interferência ocorre quando, sabendo que após o frio (outono/inverno) deve vir o calor (primavera/verão), ela traz/borda o sol. Suas interferências são feitas pelo seu dom: o tecer. Ela tece a natureza, a vida, a beleza, a arte: seus tapetes mágicos ganham formas e geram vidas. Há uma duração definida pelo tempo e pelo seu trabalho manual. As figuras relacionadas ao tempo e ao tecer dão sentido ao conto, recriando o mundo concreto, reforçando sua importância no texto. Essas figuras táteis, gustativas e visuais, relacionadas às modulações do tempo e da arte de tear, ao constituírem conectores isotópicos, geram um texto pluriisotópico, com a repetição desses traços. 


\begin{tabular}{|c|c|}
\hline TRAÇOS SENSORIAIS & TEMPO E TECER \\
\hline TÁTEIS & $\begin{array}{l}\text { tear, tecer, lançar. } \\
\text { rebordava, desenhava, traço. } \\
\text { linha, fios, pentes, tapete, } \\
\text { lançadeira, algodão, lãs, felpudo, } \\
\text { tecido. } \\
\text { vento, chuva, quentes, frio. }\end{array}$ \\
\hline GUSTATIVAS & $\begin{array}{l}\text { fome, peixe. } \\
\text { sede, leite. }\end{array}$ \\
\hline VISUAIS & $\begin{array}{l}\text { escuro, noite, penumbra, } \\
\text { escuridão. } \\
\text { clara, cor da luz, claridade, sol, dia, } \\
\text { manhã. } \\
\text { nuvens, chuva. }\end{array}$ \\
\hline
\end{tabular}

Quadro 1. Isotopia: traços sensoriais.

O reforço ao tempo é dado por meio dos substantivos ("tempo", "hora"), dos advérbios temporais ("logo", "depois", "ainda", "em breve", "nunca"), além da palavra "durante", que pode ser adjetivo (que dura) ou preposição (no curso de, duração de). Há, ainda, o uso de expressões como, "hora a hora" e "primeira vez". Porém, ao final do texto inicia-se uma mudança de estado do sujeito moça tecelã: ela traz o tempo em que se sente sozinha e, pela primeira vez, pensa como seria bom ter um marido ao lado. Estamos diante, agora, de um sujeito em falta, que passa a almejar um objeto de valor/marido. Temos, portanto, um sujeito modalizado pelo querer e pelo poder.

Até então, a moça tecelã era um sujeito em estado relaxado, realizado, com um éthos da justa medida, com características de pessoal gentil (sempre disposta a fazer e trabalhar), prudente (esperava a própria natureza se manifestar), humilde (seguia o ritmo do tempo) e generosa (se a flor está sofrendo com o calor, por que não refrescá-la?). É interessante lembrar que, para Greimas e Fontanille (1993, p. 117), a generosidade é definida como a "disposição para dar mais do que se espera", evidenciando um sujeito desapegado e de moralização positiva.

O destinador da moça tecelã é o tempo, que a manipula através dos ciclos temporais. Ela aceita esse contrato, pois lhe parece e é confiável. Mas, por um sentimento de falta, ou até mesmo por questões de moralidade que o grupo social determina, ela rompe esse contrato para 
fazer o seu próprio tempo preenchido com um marido e filhos, o que a torna, portanto, um sujeito realizado. Sobre essa falta, o psicólogo Aldo Carotenuto diz:

viver a falta e procurar superá-la mediante a busca da totalidade perdida. Se eu me encontro numa fase em que experimento agudamente essa dor, o outro adquire o valor de uma esperança (CAROTENUTO, 2005, p. 54).

Se a própria moça tecelã traz o tempo da solidão, é possível fazermos uma leitura de que ela se sentia incompleta. Ela seria, portanto, um sujeito virtualizado que só se sentiria pleno se estivesse em conjunção com os valores tradicionais da cultura e da sociedade em que está inserida, em que se faz necessário constituir uma família. Essas relações levam a segunda possibilidade de leitura desse texto: seria apenas a pressão sócio-cultural que a leva a crer que, para ser feliz e completa, precisaria casar e ter filhos? Seria, então, o seu novo destinador, a sociedade, que passa a manipulá-la?

A moça tecelã que, até então, estava em conjunção com o destinador tempo, rompe esse contrato. A primeira transformação que ocorre é, exatamente, quando ela passa a se sentir só e deseja ter um homem ao seu lado. É esse estado de falta que leva à transformação. É interessante analisar duas frases que se repetem em dois momentos do texto: "Tecer era tudo o que fazia. Tecer era tudo o que queria fazer". Sabendo do seu extraordinário talento para tecer e, com esse dom, fazer coisas tão belas e úteis que resultavam em alegria e mudanças, ela poderia crer que, com esse dom, ela poderia também fazer e trazer a sua própria felicidade e completude. Essa crença em si mesma poderia desencadear uma nova paixão, o capricho.

Antes de partirmos para a segunda parte do texto, vamos apresentar algumas reflexões teóricas a respeito da noção de paixão em semiótica, vislumbrando os autores que mais se detiveram sobre essa questão. 
Cronologicamente, a definição da noção de paixão se firma no livro Semiótica das paixões, de Greimas e Fontanille (1993). Segundo os autores, "as paixões aparecem no discurso como portadoras de efeitos de sentido muito particulares provenientes da organização discursiva das estruturas modais" (GREIMAS; FONTANILLE, 1993, p. 21). Fontanille e Zilberberg (2001), dispondo de mais ferramentas para a análise, voltam a definir a paixão, dando a ela uma forte carga tensiva. Para Fontanille (2007), "a paixão obedece a uma lógica tensiva. [...] A maior parte dos efeitos passionais, no discurso, pode ser apreendido na perspectiva das variações de intensidade e de quantidade" (FONTANILLE, 2007, p. 188). Por fim, Denis Bertrand, em Caminhos da Semiótica Literária, analisa a paixão "enquanto efeito de sentido inscrito e codificado na linguagem" (BERTRAND, 2003, p. 358).

\section{$2^{\mathrm{a}}$ parte: Ruptura com o tempo}

Não esperou o dia seguinte. Com capricho de quem tenta uma coisa nunca conhecida, começou a entremear no tapete as lãs e as cores que Ihe dariam companhia. E aos poucos seu desejo foi aparecendo, chapéu emplumado, rosto barbado, corpo aprumado, sapato engraxado. Estava justamente acabando de entremear o último fio da ponta dos sapatos, quando bateram à porta.

Nem precisou abrir. O moço meteu a mão na maçaneta, tirou o chapéu de pluma, e foi entrando em sua vida.

Aquela noite, deitada contra o ombro dele, a moça pensou nos lindos filhos que teceria para aumentar ainda mais a sua felicidade.

E feliz foi, durante algum tempo. Mas se o homem tinha pensado em filhos, logo os esqueceu. Porque, descoberto o poder do tear, em nada mais pensou a não ser nas coisas todas que ele poderia the dar.

- Uma casa melhor é necessária - disse para a mulher. E parecia justo, agora que eram dois. Exigiu que escolhesse as mais belas lãs cor de tijolo, fios verdes para os batentes, e pressa para a casa acontecer.Mas pronta a casa, já não Ihe pareceu suficiente. - Para que ter casa, se podemos ter 
palácio? - perguntou. Sem querer resposta, imediatamente ordenou que fosse de pedra com arremates em prata.

Dias e dias, semanas e meses trabalhou a moça tecendo tetos e portas, e pátios e escadas, e salas e poços. A neve caía lá fora, e ela não tinha tempo para chamar o sol. A noite chegava, e ela não tinha tempo para arrematar o dia. Tecia e entristecia, enquanto sem parar batiam os pentes acompanhando o ritmo da lançadeira.

Afinal o palácio ficou pronto. E entre tantos cômodos, o marido escolheu para ela e seu tear o mais alto quarto da mais alta torre.

- É para que ninguém saiba do tapete - disse. E antes de trancar a porta à chave, advertiu: - Faltam as estrebarias. E não se esqueça dos cavalos!

Sem descanso tecia a mulher os caprichos do marido, enchendo o palácio de luxos, os cofres de moedas, as salas de criados. Tecer era tudo o que fazia. Tecer era tudo o que queria fazer.

E tecendo, ela própria trouxe o tempo em que sua tristeza lhe pareceu maior que o palácio com todos os seus tesouros. E pela primeira vez pensou como seria bom estar sozinha de novo. (COLASSANTI, 2004, p. 7-12, grifos nossos).

O texto começa rompendo com o tempo: "não esperou o dia seguinte". A partir daqui, num primeiro momento, ela mesma determinará o que e quando fazer, atendendo apenas as necessidades dela mesma. Este comportamento é gerado pelo sentimento de capricho. Na frase "com capricho de quem tenta uma coisa nunca conhecida, começou [...].", o substantivo capricho funciona como um desencadeador de isotopias, permitindo duas leituras. Vejamos:

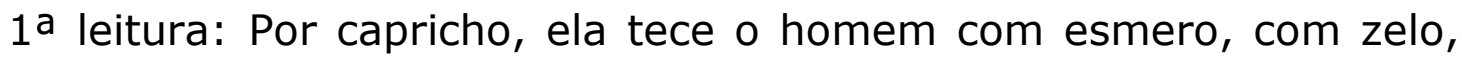
com apuro. No dicionário Houaiss (2008), a palavra pode também significar "ornamento fora do comum, mas bem executado". Por ser uma tecelã talentosa, ela faz seus trabalhos com caprichosa perfeição.

2a leitura: Por capricho, sendo levada pela impulsividade (traços de intensidade e aspectualidade) e pela teimosia e sem justificação aparente, 
ela decide ter um companheiro, provocando uma mudança súbita de comportamento.

Nessa segunda leitura, podemos obter um reforço do estilo passional por meio do dicionário Houaiss (2008), que define capricho como "vontade repentina, sem justificativa; capricheira (ex.: c. de gente idosa, de criança, de mulher)". Por extensão, capricho pode significar "falta de constância, de regularidade, variabilidade".

Se falta à emoção o traço duratividade, este se inscreve firmemente na paixão. Podemos admitir que a emoção se transforma em paixão quando ela molda o percurso inteiro do sujeito (FONTANILLE; ZILBERBERG, 2001, p. 282).

Com e por capricho ela tece o homem que entra na sua vida. Os seus bordados não só adquirem forma humana, como concretizam seu próprio desejo. Ela seleciona as lãs e as cores que dariam forma ao homem que ela desejava. Mas não poderia ser um marido qualquer: ela escolheu o chapéu, o sapato engraxado, o rosto barbado, o corpo aprumado. Estamos diante de um "sujeito do capricho".

Para a semiótica, o capricho pode ser um tipo de paixão, por produzir efeitos de sentido "afetivos" ou "passionais", transformando o sujeito. Se a paixão é da ordem do excesso, do ponto de vista da ação, vemos na tecelã um sujeito impulsivo, acelerado.

Esta paixão leva a uma ação "impulsiva", em que o sujeito age "sob o controle do poder e do querer" (FONTANILLE, 2007, p. 179). Temos, portanto, um impulso tensivamente acelerado. Essa aceleração é mostrada no texto quando ela não espera o dia chegar e o homem que ela deseja vai entrando na sua vida sem avisar, sem pedir permissão. Essa

impaciência exprime o estado iterativo de um sujeito disjunto que virtualiza, ao modo da intensidade, sua conjunção com um objeto desejado. A impaciência é uma modalidade intensiva do querer (BERTRAND, 2003, p. 360). 
Assim, de um momento para outro, a moça se vê tomada pela paixão, pela felicidade e pela completude. Ainda tomada pelo estado passional, ela imagina os "lindos filhos que teceria para aumentar ainda mais a sua felicidade". O pronome possessivo "sua" é restritivo. Embora a moça manifestasse querer formar uma família, suas ações e sentimentos são individualistas: ter marido e filhos são apenas parte de seu desejo caprichoso.

Encontramos aqui uma paixão: um desejo caprichoso, que querer ser feliz nos moldes tradicionais da cultura, pela aquisição dos objetos necessários para isso. Segundo Fontanille e Zilberberg (2001, p. 299), "assim que uma paixão é identificada e denominada, não estamos mais na ordem da dimensão passional viva, mas na dos estereótipos culturais da afetividade". Até esse momento, a moça tecelã é um sujeito da espera, que quer e sabe que pode ser feliz.

Ela deposita toda sua confiança nesse homem, por meio do estabelecimento de uma relação contratual. Ela espera que, através dele, possa alcançar o que deseja. O sujeito de estado 'pensa poder contar' com o outro (espera fiduciária). Mas o homem logo se transforma na narrativa. Assim como ela, ele pensa, deseja e quer. Quando percebe o "poder do tear", o homem torna-se o anti-sujeito (ou anti-destinador), privando-a de formar uma família com filhos. Ele não compartilha com ela os mesmos valores: "mas se o homem tinha pensando em filhos, logo os esqueceu".

Esta frase nos permite dizer que foi estabelecido um contrato fiduciário imaginário por parte do sujeito moça, pois "o sujeito do fazer não se encontra de maneira nenhuma engajado, sendo o produto da 'imaginação' do sujeito de estado" (GREIMAS, s/d, p.5). Vemos que há uma relação fiduciária estabelecida entre o sujeito moça e o simulacro que ela construiu, e não uma relação intersubjetiva:

$$
\begin{array}{ll}
\mathrm{S}_{1} \text { querer }\left[\mathrm{S}_{2}\right. & \left.\longrightarrow\left(\mathrm{S}_{1} \cap \mathrm{Ov}\right)\right] \\
\mathrm{S}_{1} \text { crer }\left[\mathrm{S}_{2}\right. \text { dever } & \left.\longrightarrow\left(\mathrm{S}_{1} \cap \mathrm{Ov}\right)\right]
\end{array}
$$


Diante da frustração de não ter seus desejos realizados pelo seu companheiro, ela passa a crer que os caprichos dele companheiro são justos. Ela renuncia, assim, ao seu desejo materno e passa a executar as tarefas determinadas pelo marido que passa a ser agora o seu destinador. Mesmo enclausurada, ela não percebe seu aprisionamento.

Embora resignada, o seu querer não fica nulo, ela "simplesmente adotou a hierarquia inversa, sendo o seu querer sujeito à força do seu dever" (FONTANILLE, 2007, p. 181). Essa resignação é temporária, pois, logo veremos que, pacientemente, a tecelã aguarda o momento para realizar uma ação. "A paciência é a disposição do espírito daquele que sabe esperar sem perder a calma" (GREIMAS, s/d, p. 7). É na ação terceira sequência do esquema passional canônico - que está inserida a emoção que "corresponde a crise passional que prolonga e atualiza a sensibilização: é o momento da patemização que manifesta o discurso passional" (BERTRAND, 2003, p. 374).

O homem, por ambição, passa a exigir que ela borde todos os desejos dele. Suas vontades são cada vez mais exigentes, tomando todo o tempo da mulher, que borda somente os caprichos do seu companheiro: são ordens, exigências, prazos e autoritarismo.

Temendo a disjunção com seu objeto de valor, o marido prende a mulher e o tear na mais alta torre, mantendo-os isolados do mundo. Ele não o compartilha nem mesmo com a sua companheira, que passa a ser apenas o sujeito do fazer, cumprindo ordens e executando os trabalhos ordenados.

Ele também se torna um sujeito modalizado pela paixão, a ambição, que é um "forte desejo de poder ou riquezas, honras ou glórias, cobiça, cupidez" (Houaiss, 2008). Ele quer manter a conjunção com a riqueza através do tear, mas seu desejo é tão intenso que ele não quer e não pode esperar.

Com o tempo, a moça percebe que sua tristeza é maior que seu desejo caprichoso. Ela se vê tomada de obrigações e sem tempo para fazer o que queria. Ela passa a perceber que aquilo que ela acreditava ser 
verdade, não era. Ela estaria, portanto, vivendo uma mentira (nem parecia, nem era verdade). Por conseguinte, a moça tecelã, passa a compreender que "tecer era tudo o que fazia" e que "tecer era tudo o que queria fazer". Ela percebe que somente tecer a fazia feliz. O "tecer" seria, portanto, o companheiro que ela queria ter de volta e que a completava, pois era no tecer que ela se sentia livre, autônoma, capaz de determinar as suas próprias regras e suprir suas necessidades.

Observamos nesse percurso que há um aumento de tensão, pois, embora a moça inicialmente confie que o homem a faria feliz, com o tempo, ela se decepciona, ao saber que ele não a tornaria um sujeito realizado. O pico da tensão se dá no momento em que ela conclui que é melhor voltar a estar sozinha.

"Ela própria trouxe o tempo em que sua tristeza lhe pareceu maior que o palácio com todos os seus tesouros". A bordadeira passa a ser um sujeito infeliz, pois sabe não poder ser feliz com aquele homem. A sua tristeza é extensa e cada dia mais intensa, pois compreende que é impossível a conjunção desejada. Aquele rapaz passa a ser uma presença invasora e devastadora. Ela pensa, então, "como seria bom estar sozinha de novo".

Novas mudanças actanciais ocorrem no conto. O moço deixa de ser o destinador da mulher e passa a ser o anti-sujeito. Ela passa a ocupar o papel de destinador-julgador, buscando assim, restabelecer a confiança e o estado de conjunção inicial. Na terceira parte do texto, veremos como essa falta será reparada por ela.

Ao se reencontrar com o tempo ("ela trouxe o tempo"), ela percebe como era feliz quando vivia em harmonia com ele e deseja voltar a sua vida anterior, sem um marido. Só nesse momento da sua vida é que ela compreende que, mesmo sozinha, ela era um sujeito completo, preenchido pelo próprio tempo e pelo prazer de bordar.

Nesse texto há uma clara relação entre desejo e linha de tempo. 0 desejo tem uma duração, com acelerações (a tecelã desejava tanto ter um companheiro que passa a fazer seus bordados com pressa e sem 
parar) e desacelerações (exausta, a moça se percebe triste e sem vontade de executar o tear).

Quanto ao tempo, esse se prolonga na linha da extensidade, não afetado pelas explosões das paixões, das ações e dos ritmos. Nele está o esvaziamento do desejo, a perda da sua potência e da sua intensidade.

[...] ao incorporar a afetividade ao percurso de produção do sentido nos textos, a semiótica a integra sob a denominação de intensidade, grandeza oposta à extensidade, para formar o par designado pelo termo tensividade, lugar imaginário em que a intensidade (os estados de alma) e a extensidade (os estados de coisas) se juntam (TEIXEIRA, sd, p. 7).

A intensidade e a extensidade evoluem de forma inversa uma da outra. Enquanto o capricho é intenso/tônico, com picos de explosão passional, sua duração é curta. O tempo, ao contrário, tem baixa tonicidade, pois seu campo afetivo, embora mínimo, possui larga extensão. "À medida que a extensão estreita-se e que a intensidade aumenta, a profundidade diminui" (FONTANILLE, 2007, p. 102).

Tônico INTENSIDADE (desejo caprichoso) = os estados de alma

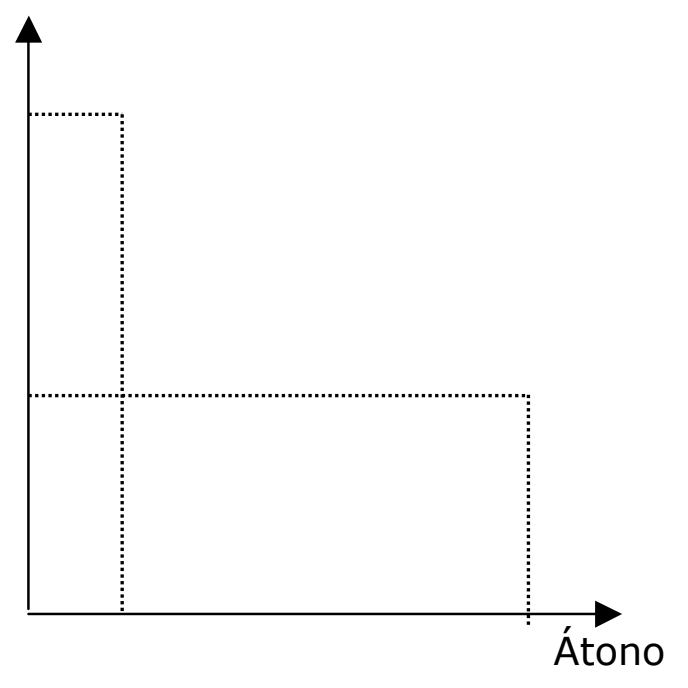

EXTENSIDADE (tempo) $=$ os estados de coisas

Quadro 2. Relação de intensidade e de extensidade. 


\section{$3^{a}$ parte: Reencontro com o tempo}

Só esperou anoitecer. Levantou-se, enquanto o marido dormia, sonhando com novas exigências. E descalça, para não fazer barulho, subiu a longa escada da torre, sentou-se ao tear.

Desta vez não precisou escolher linha nenhuma. Segurou a lançadeira ao contrário e, jogando-a veloz de um lado para o outro, começou a desfazer seu tecido. Desteceu os cavalos, as carruagens, as estrebarias, os jardins. Depois desteceu os criados e o palácio e todas as maravilhas que continha. E novamente se viu na sua casa pequena e sorriu para o jardim além da janela.

A noite acabava quando o marido estranhando a cama dura, acordou e, espantado, olhou em volta. Não teve tempo de se levantar. Ela já desfazia o desenho escuro dos sapatos, e ele viu seus pés desaparecendo, sumindo as pernas. Rápido, o nada subiu-Ihe pelo corpo, tomou o peito aprumado, o emplumado chapéu.

Então, como se ouvisse a chegada do sol, a moça escolheu uma linha clara. E foi passando-a devagar entre os fios, delicado traço de luz, que a manhã repetiu na linha do horizonte. (COLASSANTI, 2004, p. 12-17, grifos nossos).

O tempo transcorrido adquire no conto um caráter de arrependimento e de vingança. A partir do momento em que a moça toma consciência de que seu desejo caprichoso só lhe trouxe sofrimento e tristeza, ela decide mudar a situação, aniquilando seu algoz, o responsável por toda sua tristeza. "A vingança é um reequilíbrio dos sofrimentos entre sujeitos antagonistas" (GREIMAS, s/d, p. 15).

$\mathrm{Na}$ terceira parte do conto, a moça restabelece seu estado de conjunção com o tempo logo no início do texto: "esperou anoitecer". Ela readquire as qualidades da espera e do discernimento. Pacientemente a moça espera anoitecer, espera o marido adormecer, confabula seus atos e é prudente em suas ações. Os pés descalços estabelecem uma relação com a realidade, com a lucidez.

Enquanto o homem dorme, "sonhando com novas exigências", ela começa a agir. No dicionário online Houaiss, a palavra sonhar tem como 
significado: "ter delírios", "entregar-se a fantasias e devaneios a respeito de coisas inacessíveis ou impossíveis", "fazer castelos no ar", "desejar com insistência", "ansiar".

Utilizando, ainda, o mesmo dicionário, temos como antônimo de ação a palavra adormecimento. Parece-nos possível fazer um paralelo entre a ação da moça tecelã e o marido adormecido. Enquanto ela está acordada e lúcida, ela tem força de ação; já ele está num estado desacordado, inerte. A ação da mulher é dirigida por um único objetivo: anular o homem. O adormecimento do homem, embora tire dele qualquer praticidade e objetividade, amplia, sem limites, seus desejos e delírios. Ela está centrada e ele disperso.

Ela, então, começa a desfazer todos os bordados, frutos do capricho: palácio, cavalos, carruagens, criados e, por fim, o marido. Sua ação de jogar a lançadeira ao contrário para desfazer os tecidos provoca ritmos, gerando sensações de pulsações. A moça inicia com rapidez e, à medida que os objetos não desejados vão desaparecendo e seu mundo é restabelecido, as pulsações vão diminuindo de frequência, ficando menos intensas e mais espaçadas. $E$, finalmente, seu estado é de relaxamento, um sujeito em estado de distensão, aliviado por saber que não pode não ser.

O percurso, nesse momento, registra a diminuição da tensão, chegando ao relaxamento. Ela sai do estado de grande tristeza (aspecto/profundidade), gerado pelo sentimento da falta e realiza um programa de liquidação da falta. Esse programa, levando-a a uma ação, propicia que ela volte à situação inicial. Ela assume "o papel de destinador-julgador e sanciona negativamente o anti-sujeito que não cumpriu o esperado ou que exerceu um fazer contrário e prejudicial aos seus projetos" (BARROS, 1990, p. 70). A sanção realizada por ela é pragmática.

A forma que ela encontra para acabar com a falta é eliminar o sujeito responsável por seu estado passional, criando uma paixão tensa e malevolente. A decepção a leva a querer fazer mal. A moça tecelã, 
embora comece com o amor, termina com o estado passional do desamor pelo marido. "A vingança liquida a falta fiduciária, que diz respeito às relações intersubjetivas, e soluciona a crise de confiança" (BARROS, 1990, p. 70).

Vejamos abaixo o quadrado formulado pela semioticista Diana Barros que mostra os percursos afetivos do sujeito:

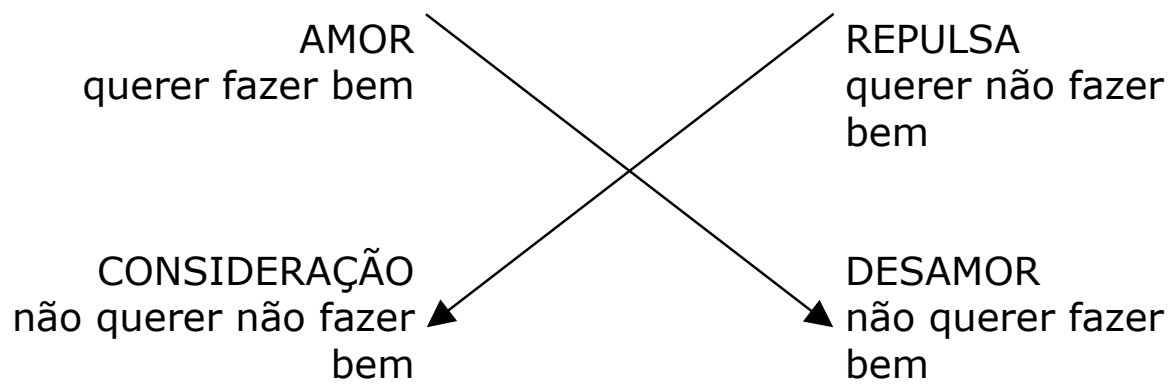

Quadro 3. (Cf. BARROS, 1990 p. 67).

O estado de paixão afeta a forma da matéria, diluindo-a no espaçotempo, pois, enquanto ela desfaz os objetos, o tempo continua e o dia chega. Seu frenesi começa durante a noite e se encerra ao amanhecer, alterando o estado das coisas e da alma.

Quando o dia vai chegando, o marido acorda, mas sem tempo para agir, apenas vê seu corpo desaparecendo e o nada toma conta dele. Ele volta a ser apenas um objeto da moça que, quando não mais o queria, se desfaz dele. Para ele, "o sono é (foi) o prelúdio da morte", o início do seu fim.

Ao se desfazer do marido, a moça restabelece seu estado inicial de felicidade. Temos, assim, um percurso passional completo, de acordo com o modelo proposto por Barros (1990, p. 63). 
FELICIDADE/alegria

(relaxamento)

AFLIÇÃO/inquietação

poder ser
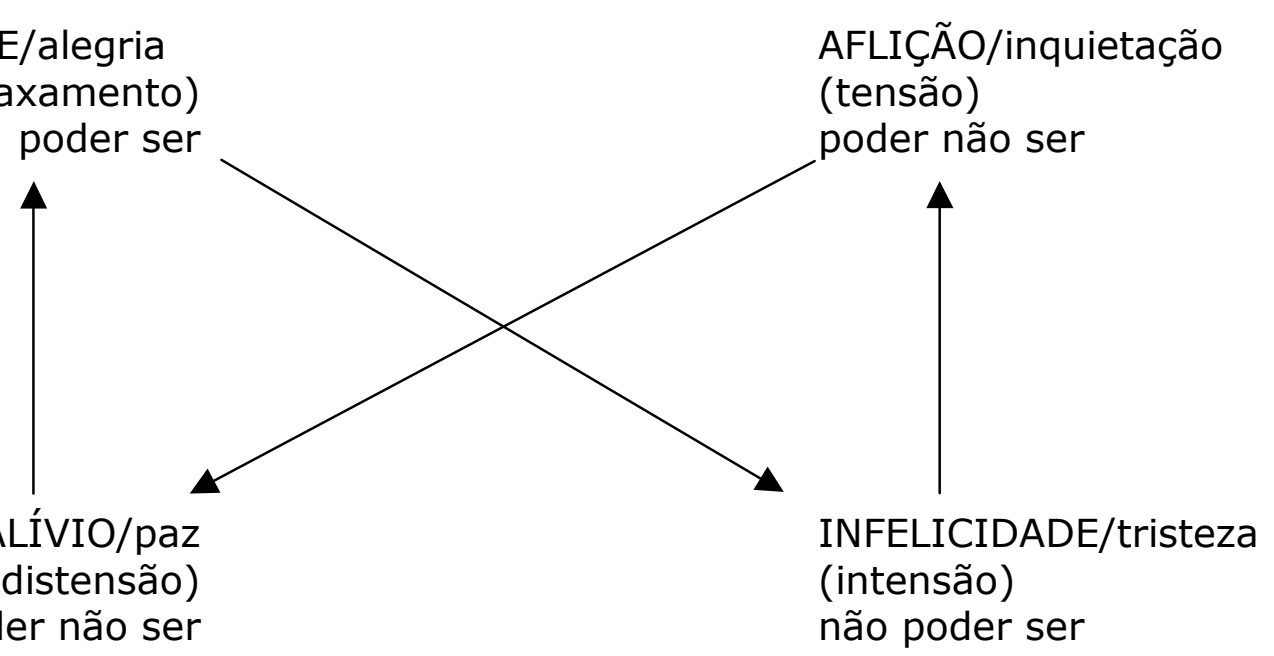

(tensão)

poder não ser

ALÍVIO/paz

(distensão)

não poder não ser

Quadro 4. Percurso passional completo.

A liberdade e a felicidade dela chegam junto com o sol. Seus gestos são delicados e lentos. Ela está em um estado de completo relaxamento e desaceleração, pois sabe que pode ser feliz apenas fazendo seu bordado, em harmonia com o tempo.

Vemos nesse conto de Marina Colasanti "o 'nascimento' e a 'morte' de uma paixão" tomando "a forma, do ponto de vista do objeto, de crises aspectuais e, do ponto de vista do sujeito, de crises fiduciárias, tanto umas quanto as outras assegurando ou não a continuidade passional" (FONTANILLE e ZILBERBERG, 2001, p. 277).

Para se ter um estado passional, duas dimensões são afetadas no texto: a modal e a fórica. A dimensão modal envolve as competências do sujeito (querer, dever, saber, poder e crer). A dimensão fórica atua na intensidade e extensidade, ambos projetados na aspectualidade (tempo e espaço), gerando efeitos rítmicos.

O capricho se mostra, nesse texto, intenso e pontual, com duratividade breve, tendo se firmado como uma paixão responsável por moldar todo o percurso do sujeito. Constatamos este estilo passional, ao analisarmos a aspectualidade, a modalidade e a tensividade do conto. $\mathrm{Na}$ paixão do capricho, falta constância e regularidade no sujeito patemizado. Seja por impulso, seja por vontade repentina, o capricho, embora tenha duratividade breve, apresenta picos de intensidade (tônico). Ele "chega" rápido, mas sua duração é breve. 
O sujeito moça tecelã, afetado por essa paixão, é modalizado pelo querer/poder ser um sujeito pleno. Para tal fim, esse sujeito, estabelece um contrato fiduciário com o sujeito marido, que seria o responsável por trazer o seu objeto de valor: família/filhos. Ela acreditava que ele poderia e faria isso. Mas se ele prometeu (fórmula condicional), logo esqueceu. Sua promessa ficou abalada, caminhando para a ameaça. Ele, tornando-se seu anti-destinador, passa a manipulá-la pela promessa-ameaça. O programa de uso passa a ser "a eficácia da palavra", exatamente quando ocorrem as debreagens de segundo grau no texto, dando voz direta ao homem.

Mesmo diante da pressão gerada pelo seu manipulador-algoz, a moça percebe que, embora a ameaça seja maior, a confiança em seu manipulador é mínima, possibilitando, assim, a disjunção entre a moça e o rapaz. Ela nota o quão frágil e efêmera é sua relação com aquele homem. Ela não mais crê na possibilidade de ser feliz em conjunção com o marido. Sua convicção é forte, não "hesitando em sacrificar o objeto em busca, a fim de permanecer na fase afetiva que escolheu para sua existência" (FONTANILLE; ZILBERBERG, 2001, p. 292).

O conto mostra uma sequência de estados patêmicos, em conjunção ou disjunção com o objeto de valor, situados entre o crer e o não crer no destinador/manipulador, com diferentes valências tensivas impostas ao valor do objeto e a sanção dada.

A ruptura da tecelã não é feita somente com o marido, mas com os valores determinados pela sociedade, segundo a qual uma mulher só é feliz se casar e tiver filhos. Ela provoca a quebra de um estereótipo cultural no qual a mulher tem uma postura passiva diante do seu papel/função social. Seu éthos pré-discursivo é de uma mulher submissa e cumpridora das regras estabelecidas pela sociedade. No início, ela se apresenta com um éthos da justa medida (estereotipado), mas, a se ver em falta, decide tomar as rédeas de sua vida. Ela assume, assim, o papel dominante e julgador, passando a ter um éthos hiperbólico, com ações extremas. 
A moça tecelã é da ordem do inacabamento, ao romper com "um modelo pré-construído", com papéis que a sociedade pré-determina para a mulher. O dever deixou de reger o querer, permitindo a mobilização do sujeito na sua esfera de comunicação. Ela também se configura como um sujeito da ordem da ambivalência, pois, mesmo ao adotar ações abruptas e extremas (aniquilou o marido e eliminou todos os objetos provenientes do capricho), mantém um "tom de voz" sereno. Apenas sorriu quando se viu em disjunção com o que não queria, e delicadamente voltou a fazer o que sempre fez e quis.

Mesmo com esta falta, a moça tecelã decidiu que queria e poderia ser feliz. Percebeu que a felicidade pode ser construída de várias maneiras, dependendo, apenas, das escolhas e do olhar do sujeito. 


\title{
2.2. ENUNCIAÇÃO
}

\subsubsection{As estratégias de enunciação no universo infantil de Manoel de Barros pelo conto "O Menino que Carregava Água na Peneira"}

\begin{abstract}
"[...] quisera uma linguagem que obedecesse a desordem das falas infantis do que as ordens gramaticais. Desfazer o normal há de ser uma norma. Pois eu quisera modificar nosso idioma com as minhas particularidades. Eu queria só descobrir e não descrever. O imprevisto fosse mais atraente do que o dejá visto."
\end{abstract}

Manoel de Barros $^{13}$

O livro Exercícios de ser criança, de Manoel de Barros, lançado em 1999, pela editora Salamandra, tem duas histórias: "O menino que carregava água na peneira" e "A menina Avoada". Para trabalharmos com a enunciação, optamos pelo primeiro conto da obra. A análise busca recuperar o Plano do Conteúdo do texto verbal, recriado no texto visual, depreendendo os modos de significar, distinguindo os efeitos de sentido produzidos.

A história é composta por 12 ilustrações de bordados (fotografados) distribuídas em 24 páginas. Neste livro, a ilustração ganha uma posição de destaque ao estabelecer uma relação entre os elementos que compõem a obra, captando e recriando o verbal. Notamos um estreito diálogo entre a imagem visual e a palavra. Em alguns momentos, as imagens confirmam o que o texto verbal diz, em outros, antecipam, ou até mesmo acrescentam, informações ao texto escrito.

\footnotetext{
${ }^{13}$ BARROS, Manoel de. Memórias inventadas: a segunda infância. $1^{\text {a }}$ reimpressão.
} São Paulo: Planeta, 2007, p. 45. 
Este trabalho utiliza, ainda, a tensividade como ferramenta de análise da aspectualização (tempo e espaço), compreendendo, assim, as instâncias do tempo entre expressão e conteúdo, por ser aqui que ocorrem as gradações e modulações transformadoras do mítico ao social, do passado para o presente/futuro.

Sendo um corpus extenso, fizemos um recorte metodológico. A análise mantém todo 0 texto verbal para melhor trabalhar 0 nível discursivo do percurso gerativo do sentido, esmiuçando a enunciação e o éthos. Na análise do texto semi-simbólico, selecionamos duas ilustrações, respaldando-nos em Brøndal, cuja teoria afirma que a unidade remete à totalidade, privilegiando as imagens de apresentação (título) e de conclusão da história.

\subsubsection{Análise do texto verbal}

Iniciamos a análise apenas com o enunciado verbal, subdividindo em plano do conteúdo e plano da expressão para tornar o trabalho mais didático. Em seguida, faremos a análise homologando o texto verbal com o texto visual.

\section{Título: 0 menino que carregava água na peneira}

\section{Página 10:}

Tenho um livro sobre águas e meninos.

Gostei mais de um menino que carregava água na peneira.

A mãe disse que carregar água na peneira

Era o mesmo que roubar um vento e sair

\section{Página 11:}

correndo com ele para mostrar aos irmãos.

\section{Página 12:}

A mãe disse que era o mesmo que catar espinhos na água

O mesmo que criar peixes no bolso. 


\section{Página 14:}

O menino era ligado em DESPROPÓSITOS ${ }^{14}$.

\section{Página 15:}

Quis montar os alicerces de uma casa sobre orvalhos.

\section{Página 16:}

A mãe reparou que o menino gostava mais do vazio do que do cheio.

Falava que os vazios são maiores e até infinitos.

\section{Página 18:}

Com o tempo aquele menino que era cismado e esquisito Porque gostava de carregar água na peneira

Página 1915:

Com o tempo descobriu que escrever seria o mesmo que carregar água na peneira.

\section{Página 21:}

No escrever o menino viu que era capaz de ser noviça, monge ou mendigo ao mesmo tempo.

\section{Página 22:}

O menino aprendeu a usar as palavras.

Viu que podia fazer peraltagens com as palavras.

E começou a fazer peraltagens.

\section{Página 23:}

Foi capaz de interromper o vôo de um pássaro botando ponto no final da frase.

\section{Página 25:}

Foi capaz de modificar a tarde botando uma chuva nela.

Página 27:

O menino fazia prodígios.

Até fez uma pedra dar flor!

A mãe reparava o menino com ternura.

Página 28:

A mãe falou: Meu filho você vai ser poeta.

Página 2916:

${ }^{14}$ Palavra desenhada pelo bordado, não é grafia.

${ }^{15}$ Texto escrito em espiral, não linear. A espiral segue no sentido horário. 
Você vai carregar água na peneira a vida toda.

\section{Página 31:}

Você vai encher os

vazios com as suas

PERALTAGENS ${ }^{17}$

E algumas pessoas

vão te amar por seus

DESPROPÓSITOS. ${ }^{18}$ (BARROS, 1999, p. 10-31)

\section{Plano do Conteúdo:}

O texto se inicia com uma debreagem enunciativa actancial (eu) e temporal (presente do indicativo, seguido do pretérito perfeito). Entretanto, na categoria espacial, a debreagem é enunciva, por não projetar no enunciado o "aqui" de onde fala o narrador, dando a impressão de que ele enuncia de um espaço indeterminado, um "algures". "A instância da enunciação está ausente do enunciado e o narrador não localiza nada a partir do hic" (FIORIN, 2002, p. 292). A debreagem enunciva espacial é mantida até o final do texto, não sofrendo nenhum desdobramento na narrativa.

Neste conto, a programação espacial se restringe aos programas narrativos, onde ocorrem os eventos narrados em que a instância da enunciação está ausente do enunciado. A presença de pronomes demonstrativos e de advérbios espaciais é bastante rarefeita nesse texto. Encontramos, por exemplo, o pronome "aquele" e o advérbio "sobre".

O pronome demonstrativo, além de "atualizar um ser do discurso", também situa seu espaço, mas fora da cena enunciativa. Ele também atua como distanciamento, projetando o afastamento do sujeito no enunciado, enquanto o advérbio dá uma visão de direção vertical e de ocupação, pois condensa o espaço, pontuando-o.

\footnotetext{
${ }^{16}$ Texto escrito em espiral, não linear. A espiral segue no sentido anti-horário.

${ }^{17}$ Palavras bordadas, e não tipografadas.

${ }^{18}$ Idem.
} 
O discurso se estrutura na direcionalidade e no englobamento. Os adjetivos "vazio", "cheio", "maiores" e "infinitos" colaboram para formar um espaço tópico, marcando continuidade e descontinuidade em relação a um ponto de referência inscrito no enunciado. $\mathrm{Na}$ categoria direcionalidade, os adjetivos "maiores" e "infinitos" estão relacionados às dimensões de largura e de comprimento. Na categoria englobamento, os adjetivos "vazio" e "cheio", determinam a expansão (extensão do vazio) e a condensação (concentração do cheio).

Alguns verbos, como "carregar", "sair correndo", "montar" e "encher", atuam como elementos das categorias de direcionalidade e de englobamento. "Encher", por exemplo, se insere na categoria englobante, se estendendo no espaço ("você vai encher os espaços vazios"). "Carregar" e "sair correndo" mostram uma relação direcional, produzindo afastamento. Na mesma categoria está o verbo "montar", porém com referência à dimensão de altura.

Ao adentrarmos na análise da instância temporal, temos a primeira debreagem na terceira linha do texto em que há a mudança do verbo de pretérito perfeito ("gostei") para pretérito imperfeito ("carregava"), o que - faz passar da instância enunciativa - acabado, pontual -, para a instância enunciva, gerando inacabamento e duratividade.

Logo em seguida, ocorre uma debreagem actorial quando o narrador instala no texto um interlocutor: "a mãe disse". A mãe é o narrador instaurado no texto que irá estabelecer o diálogo com o narratário (leitor). Embora esta estratégia gere a sensação de distanciamento e de apagamento de subjetividades, a mãe passa a dialogar, a ser a voz no texto. As palavras dela ressoam a voz do enunciador, em que o autor se mascara num narrador em primeira ou terceira pessoa.

A presença da mãe é sempre lembrada, retomada: "a mãe disse que" (duas vezes), "a mãe reparou", "a mãe reparava", "a mãe falou". Durante todo o processo de aquisição do garoto, há o olhar terno e cúmplice da mãe. E será ela a dar o veredicto à criança: "Meu filho, você vai ser poeta". 
Quando a voz é delegada à mãe do menino ("a mãe falou: ..."), ocorre uma debreagem enunciativa de segundo grau. Por meio dessa debreagem, o narrador dá voz a um actante do enunciado, criando o efeito de aproximação emocional, de realidade, gerando relações afetivas.

O discurso direto é resultado de uma debreagem interna $[\ldots]$, em que o narrador delega voz a um actante do enunciado. O discurso direto é um simulacro da enunciação construído por intermédio do discurso do narrador (FIORIN, 2002, p. 72).

Há outra debreagem de pessoa no texto, iniciada no momento da substituição "aquele" ("com o tempo aquele menino...") por "esse" ("você vai ser...", "você vai carregar..."). Passa-se do quadro enuncivo menino/ele para o enunciativo você/tu, mantendo aproximação e emoção.

É interessante notar que o narrador, quando não dá voz à actante mãe, se faz presente relatando, descrevendo as ações e conquistas do actante menino. Sua presença é sutil, pois ele sempre aparece após nomear a mãe do garoto. O narrador parece "borrar" as fronteiras da voz de quem fala:

(1) A mãe disse que era o mesmo que catar espinhos na água.

O mesmo que criar peixes no bolso. (BARROS, 1999, p. 12).

(2) O menino era ligado em despropósitos." (BARROS, 1999, p. 14).

Esta última frase não é dita pela mãe, mas pelo narrador. Essa é a estratégia adotada por ele para simular sua ausência, criando ilusões enunciativas. O "eu" está presente o tempo todo na narrativa. "A distinção entre instância da enunciação e do enunciado é que cria esse efeito de sentido e de objetividade" (FIORIN, 2002, p. 69). 
Voltando para a debreagem que ocorre na categoria de pessoa, com o pronome demonstrativo ("aquele"), percebemos que o texto começa com um distanciamento e fecha com uma aproximação, por meio da utilização do pronome de tratamento ("você"). Cria-se, assim, uma aproximação afetiva, de intimidade e de inclusão do sujeito. O pronome "aquele" provoca um distanciamento, inclusive espacial e temporal, sendo utilizado como simulação do olhar de um observador distante, que descreve as ações, as transformações e as aquisições do garoto (os enunciados de estado e de fazer). No momento da sanção pela performance do menino, ocorre uma mudança no texto com as debreagens da instância da pessoa ("a mãe" e "você"). O texto entra na esfera enunciativa no tempo e na pessoa provocando aproximação e emotividade.

Ao dar seu veredicto ("você vai ser...", "você vai carregar...", "você vai encher...", "e algumas pessoas vão te amar..."), a mãe utiliza o futuro do presente composto, assinalando uma ação - neste caso, o destino do menino - quase presente/eminente e acabada.

Seguindo na análise da categoria temporal, embora o texto pareça apresentar debreagens constantes, na verdade ocorrem neutralidades. Logo no início do texto, constatamos uma neutralidade dos termos com o presente e o pretérito perfeito 2 ("Eu tenho" e "Eu gostei").

Quando se neutralizam termos da categoria do tempo, o efeito de sentido que se produz é o de que o tempo é pura construção do enunciador, que presentifica o passado, torna o futuro presente, etc. Assim, com esse procedimento, passa-se da ilusão enunciativa da naturalidade dos tempos do dizer e do dito, da quimera de que o tempo linguístico é o tempo do mundo para a certeza de que o tempo é efeito de sentido produzido na e pela enunciação (FIORIN, 2002, p. 191).

Mas há, sem dúvida, debreagens temporais, que denotam a passagem do sistema enuncivo (pretérito perfeito) para o sistema enunciativo (presente, pretérito imperfeito, futuro do presente) e vice- 
versa. Só há estabilidade no texto na categoria temporal a partir da sanção da mãe, na página 21: "meu filho você vai ser poeta". Daqui até o final do conto o verbo permanece no futuro do presente composto, instalando-se no campo enunciativo.

A expressão "com o tempo" aparece duas vezes, de forma sequenciada no conto: "com o tempo aquele menino que era..." e "com o tempo descobriu...". Mas, as demais frases que vêm em seguida aceitam, por elipse, a expressão "com o tempo". Vejamos:

(3) (Com o tempo) o menino aprendeu a usar as palavras. (BARROS, 1999, p. 22).

(4) (Com o tempo) viu que podia fazer peraltagens com as palavras. (BARROS, 1999, p. 22).

(5) (Com o tempo) foi capaz de interromper o vôo de um pássaro... (BARROS, 1999, p. 23).

(6) (Com o tempo) foi capaz de modificar a tarde ... (BARROS, 1999, p. 25).

(7) (Com o tempo) o menino fazia prodígios. (BARROS, 1999, p. 27).

Esta expressão dá um caráter durativo e contínuo ao texto, podendo ser substituída pelos advérbios temporais "então" e "depois", que podem mostrar tanto um processo em desenvolvimento (seria a performance do garoto) quanto uma conclusão, um acabamento. Esses advérbios estão no sistema enuncivo, exprimindo concomitância ("então") e posterioridade ("depois").

Reforçando essa extensão na linha do tempo, a conclusão do discurso traz a frase "a vida toda", que denota um processo em andamento, um inacabamento. Temos um enunciado verbal que remete a um mundo inacabado, pois prioriza o processo e não o produto final e pontual. A linguagem verbal da obra é da ordem da duratividade, homologada, neste caso, a dinamicidade do inacabamento. 
Com o quadro das categorias de pessoa, de espaço e de tempo analisados, podemos depreender outros elementos que constroem 0 discurso, tal como a aspectualidade do sujeito. Em "O menino que carregava água na peneira", identificamos "as recorrências do modo de dizer" do sujeito menino. Ele se apresenta com um éthos, "uma maneira de habitar o espaço social", da ordem do inacabamento, dado ao questionamento, ao relaxamento. Através de figuras que transitam no texto, encontramos um garoto que gosta de fazer "peraltagens", um sujeito ligado em "despropósitos".

Segundo o Dicionário Unesp do Português Contemporâneo (2004), o substantivo "despropósito" significa disparate, absurdo, desatino, características sempre dadas aos escritores e poetas. A palavra "peraltagem" é uma forma pouco usada, arcaica, inclusive. O uso corrente dessa palavra é peraltice, que tem o sentido de travessura, de traquinagem.

Esse menino brinca com as palavras, dando a elas elasticidade de sentido, rompendo sua arbitrariedade. Ele aprende a usar as palavras, mas também a violá-las (regras gramaticais). As pessoas não o compreendem e o acham estranho, diferente, fora do padrão.

E se seus "despropósitos" têm um caráter disfórico para essas pessoas, para sua mãe, sua excentricidade a comove (axiologização eufórica). Ela sabe que aquele gosto pela escrita é o esboço de um poeta. O menino, por ter este talento fora do comum, faz prodígios, demonstrando um "extraordinário talento, precocidade" pela arte de escrever.

Em nenhum momento ele sofre assujeitamento. Ele é um sujeito livre (mobilidade) para se expressar, feliz em fazer suas "peraltagens" (quebra e diluição de referenciação), ganhando o afeto e a cumplicidade de sua mãe. 
Percebemos que as figuras relacionadas a este inacabamento dão sentido ao conto, recriando o mundo concreto, o que reforça sua importância no texto. São figuras relacionadas à temática do "fazer poético", formando conectores isotópicos.

No texto encontramos este "fazer poético" com construções frasais desconcertantes e instigantes que corroboram para a construção do simulacro de um éthos do inacabamento do sujeito. São recorrências de um modo de dizer em que se depreende o dito. Vejamos nestas frases:

(8) carregar água na peneira (BARROS, 1999, p. 10).

(9) roubar um vento e sair correndo com ele (BARROS, 1999, p. 10-11).

(10) catar espinhos na água (BARROS, 1999, p. 12).

(11) criar peixes no bolso (BARROS, 1999, p. 12).

(12) montar os alicerces de uma casa sobre orvalhos (BARROS, 1999, p. 15).

(13) fazer peraltagens com as palavras (BARROS, 1999, p. 22).

(14) fez uma pedra dar flor (BARROS, 1999, p. 27).

Temos nessas frases os "absurdos" que só um poeta e/ou uma criança podem "fazer" e/ou "imaginar". A criança é um poeta nato, exatamente por ainda não saber as regras gramaticais e as convenções sócio-linguísticas. Em O livro das ignorãças (2007), Manoel de Barros diz: "Então se a criança muda a função de um verbo, ele delira" e "as coisas que não têm nome são mais pronunciadas por crianças" (BARROS, 2007, p. 13-15). E assim fica sendo. 


\section{Plano da Expressão:}

O inacabamento registrado no plano do conteúdo, também está presente no plano da expressão e pode ser demonstrado pela presença de frases sem ponto final ("porque gostava de carregar água na peneira", BARROS, 2007, p. 11) ou pela quantidade escassa de pontuação ("a mãe disse", BARROS, 2007, p. 5). Dessa forma, o enunciado, fugindo das regras gramaticais, acaba por provocar um estranhamento no enunciatário, embora seja necessário dizer que o próprio gênero (cena genérica) literatura/poesia permite esta flexibilidade do uso da palavra e da sua paragrafação. Muitas frases estão "jogadas" no texto, parecendo não ter conexão com a frase anterior ou posterior, borrando os limites do texto, o que reforça seu caráter de inacabamento.

É interessante observar que as construções das frases que formam a estrutura do texto se repetem, criando um reforço, reiterando o ato de ler e de escrever, ratificando o "fazer poético". Vejamos:

(15) A mãe disse que ...( BARROS, 2007, p. 3).

(16) a mãe disse que ...( BARROS, 2007, p. 5).

(17) a mãe reparou que ...( BARROS, 2007, p. 9).

(18) a mãe reparava (BARROS, 2007, p. 20).

(19) a mãe falou: ...( BARROS, 2007, p. 21).

(20) O menino era ...( BARROS, 2007, p. 7).

(21) o menino viu que era ...( BARROS, 2007, p. 14).

(22) o menino aprendeu ...( BARROS, 2007, p. 15).

(23) o menino fazia ...( BARROS, 2007, p. 20).

(24) Um menino que carregava água na peneira (BARROS, 2007, p. 3).

(25) porque gostava de carregar água na peneira (BARROS, 2007, p. 11).

(26) escrever seria o mesmo que carregar água na peneira (BARROS, 2007, p. 12).

(27) você vai carregar água na peneira...(BARROS, 2007, p. 
22).

Todo o texto, desde o título, utiliza a fonte Comic Sans MS, desenvolvida especificamente como uma tipografia para crianças por ter a forma arredondada e não ser serifada, isto é, sem bordas e sem interligação com a letra que vem em seguida, valorizando cada palavra individualmente e prendendo a atenção do enunciatário por serem letras "limpas". É um tipo de letra classificado como casual, utilizado para documentos informais, como cartas, imitando a escrita manual.

Por que utilizar uma fonte tão informal para um livro? Porque seu enunciatário é a criança que se identifica com o conto - pelo seu inacabamento, pela sua poesia - e se sente familiarizada com a letra. É um enunciatário que se sente íntimo com o objeto-livro por ter elementos (simbólicos, inclusive) que remetem ao seu universo infantil. Isso, sem mencionar as ilustrações que recriam o mundo lúdico da criança, mas estas serão analisadas no próximo item, como foi proposto e justificado na introdução deste capítulo.

Percebemos que os dois planos (conteúdo e expressão) são solidários, estabelecendo relações, criando um texto sincrético. Isto ocorre pelo fato do conto constituir "um todo de significação", em que há um único conteúdo manifestado por diferentes substâncias da expressão. "Temos uma única enunciação sincrética, realizada por um mesmo enunciador, que recorre a uma pluralidade de linguagens de manifestação para constituir um texto sincrético" (FIORIN, 2006, p. 5).

\subsubsection{Verbovisual}

Analisaremos, a seguir, as duas ilustrações selecionadas juntamente com o texto verbal. Iniciamos a análise com a página-título, seguida da última ilustração, que fecha o texto. Vale lembrar que este conto, "O 
menino que carregava água na peneira", está no livro Exercícios de ser criança, onde há mais uma história, intitulada "A menina avoada".

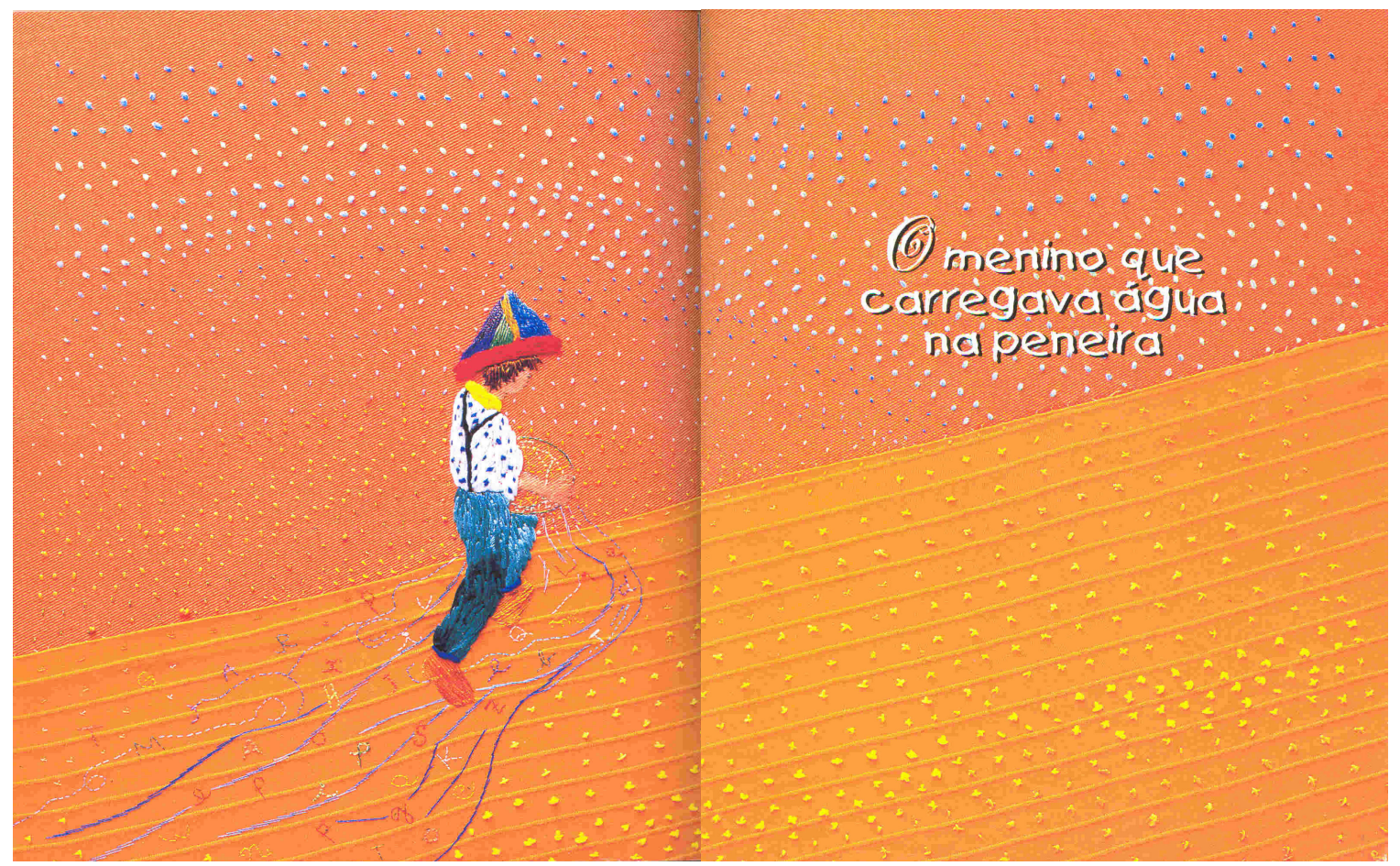

Ilustração 29. Primeira ilustração da história "O menino que carregava água na peneira" ", do livro Exercícios de ser criança, de Monoel de Barros (p. 8-9). Anexo p. 186-187.

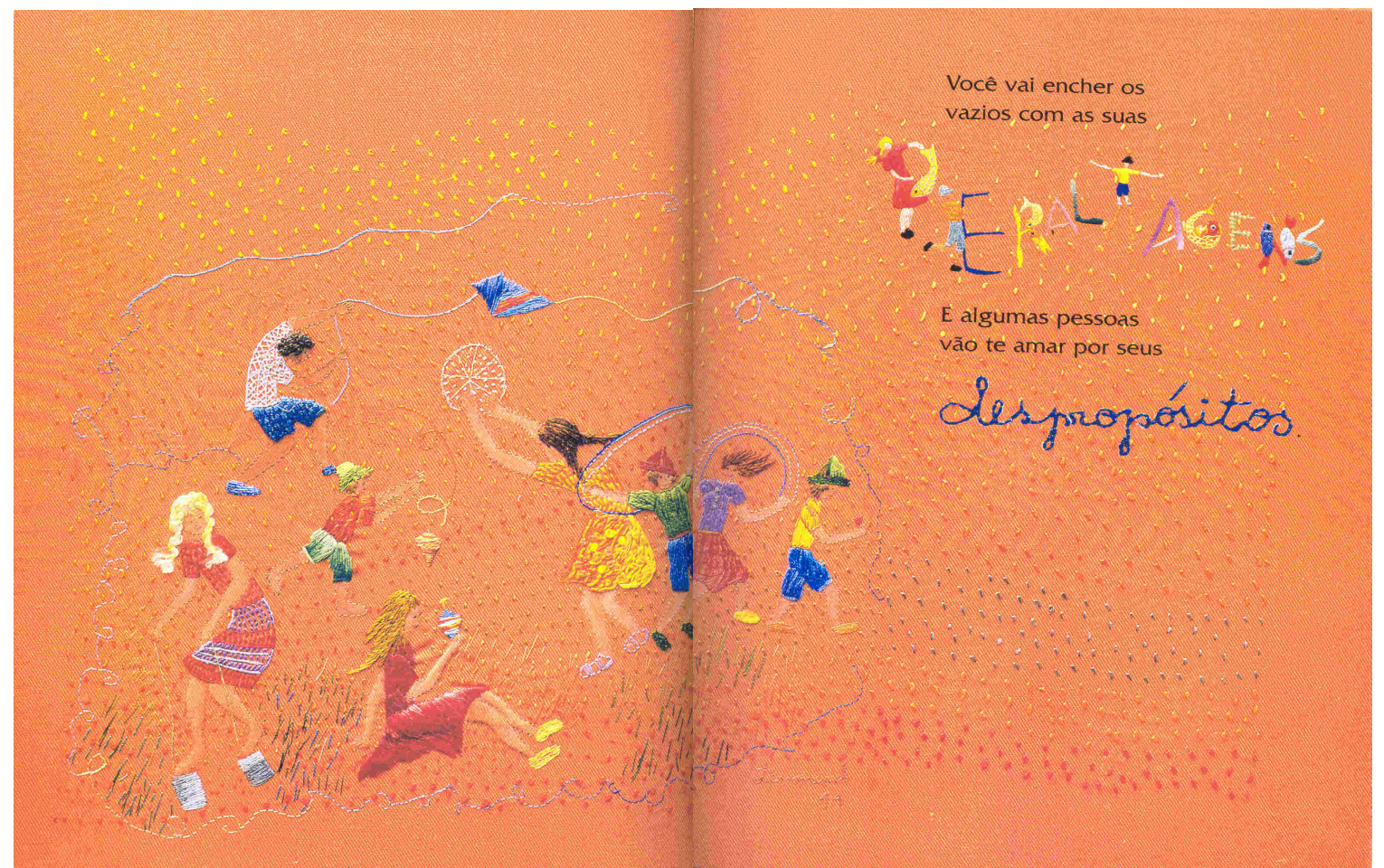

Ilustração 30. Última ilustração da história "O menino que carregava água na peneira", do livro Exercícios de ser criança, de Monoel de Barros (p. 8-9). Anexo p. 188-189. 
O livro é ilustrado com fotografias de bordados feitos pelo grupo Matizes. As artesãs bordaram os desenhos de Demóstenes Vargas, feitos exclusivamente para esta obra. Embora sejam fotografias, grande parte das características estruturais desta arte é mantida. É possível, inclusive, ver e ter a ilusão tátil dos tecidos e suas fibras, das linhas e dos volumes formados ao preencherem os desenhos, os traços, a nitidez das cores, os repuxes no tecido provocados pelo bordado.

Observamos que essas imagens ocupam toda a extensão física do livro, dividindo espaço com o texto verbal. Desde a capa e todo o miolo do livro, as ilustrações estão expandidas, sem demarcações, nem molduras.

Nossa análise preserva a linguagem do bordado, por ser nítido que seus elementos polissensoriais constituem efeitos de sentido, o que faz pertinente a inclusão de seu estatuto. Isso, sem perder de vista o fato de que sua relação com o livro adquire valor estético, com a depreensão de seu sentido e do seu sensível, pois ele se manifesta mediante práticas cotidianas.

\section{Ilustração das páginas 8 e 9:}

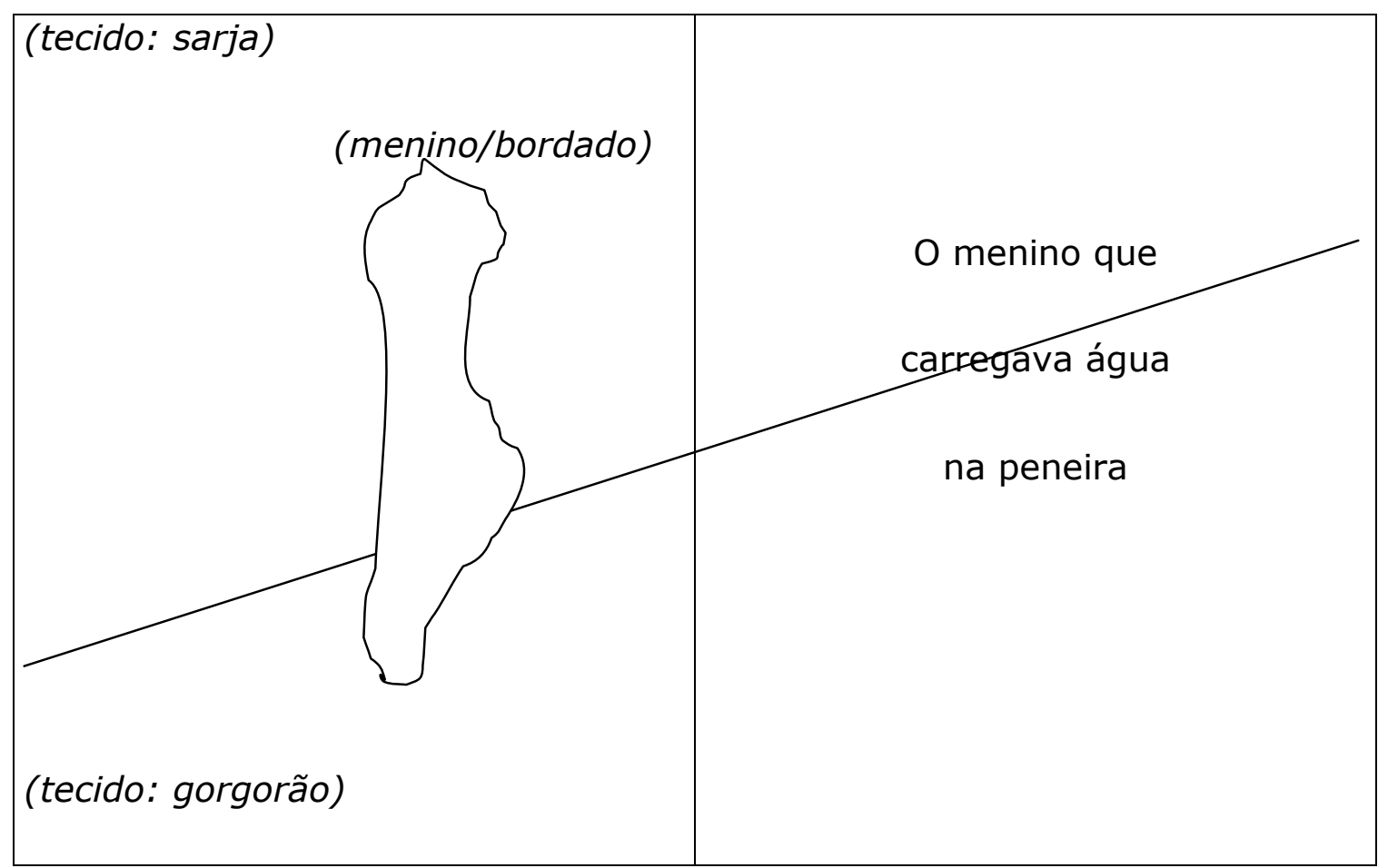

Esquema 1. Os elementos topológicos e eidéticos. 
O texto verbal aparece apenas como título da história, centralizado na parte superior da página direita. As letras são brancas, com sombras pretas, formadas por uma fonte padrão de computador, a Comic Sans MS (exceto 0 artigo masculino 0 ), uma das tipografias mais utilizadas para textos infantis de língua portuguesa. A cor branca - com relevo em preto - se comporta como neutra para não "brigar" com as cores quentes da ilustração, ganhando nitidez e destaque. Vale informar que o branco contém todas as cores e, por isso, cumpre uma função de neutralizador diante das outras cores (exceto preto e cinza). Além disso, é visualmente claro que as letras saltam sobre a ilustração, sem penetrá-la, devido ao relevo que as descola da ilustração.

Mas, só com o texto verbal, não é possível ao enunciatário saber o que será narrado nesta história. É neste momento que o texto plástico ganha espaço e destaque sobre a compreensão do texto sincrético, por fornecer elementos que antecipam o que será dito, explicando o próprio título da obra.

O bordado que ilustra as páginas é feito pela junção de dois tecidos de texturas diferentes: o encorpado gorgorão, com seus finos cordões formando nervuras, posto na parte inferior; e a sarja, com suas estrias no sentido diagonal, na parte superior. Como a semiótica trabalha com as relações e seus efeitos de sentido no texto, observamos aqui que o tecido gorgorão é mais pesado do que a sarja. Aquele está colocado na parte inferior da página, enquanto o outro, na superior. Podemos com isso estabelecer a relação pesado/inferior (gorgorão) X leve/superior (sarja), enquanto categoria topológica. Observamos, ainda, que o laranja escuro se concentra na parte superior, enquanto o laranja claro domina a parte inferior.

Vejamos abaixo, como se comportam no enunciado as categorias do plano da expressão: 


\begin{tabular}{|l|c|c|}
\hline & GORGORÃO (pesado) & SARJA (leve) \\
\hline CROMÁTICA (cor) & $\begin{array}{c}\text { Claro } \\
\text { Mesclado }\end{array}$ & $\begin{array}{c}\text { Escuro } \\
\text { Puro }\end{array}$ \\
\hline EIDÉTICA (forma) & $\begin{array}{c}\text { Nervurado } \\
\text { Pontos cruzados }\end{array}$ & $\begin{array}{c}\text { Pontos arredondados } \\
\text { TOPOLÓGICA (espaço) }\end{array}$ \\
& $\begin{array}{c}\text { Inferior } \\
\text { Diagonal }^{19} \text { ascendente }\end{array}$ & $\begin{array}{c}\text { Superior } \\
\text { Diagonal descendente }\end{array}$ \\
\hline
\end{tabular}

Quadro 5. As categorias do plano da expressão.

Os cordões do gorgorão figurativizam o terreno arado, e a terra que está adubada é representada pelos pontos em formato de " $X$ " ou bolinha, que está sendo preparada para receber as "sementes". Sobre a terra temos a figura de um garoto com uma peneira que derrama água e letras. Todas as letras estão centralizadas na parte inferior da página esquerda, sendo demarcadas pela água. São 36 letras, entre maiúsculas e minúsculas, em que algumas se repetem, faltando apenas as letras " $U$ " e "Y". O garoto está plantando letras e, para que elas "frutifiquem", ele as rega com água, responsável pela maior absorção das sementes pelo solo.

Para plantar é necessário preparar a terra. Somente com esse procedimento ela dará bons frutos. O mesmo processo ocorre com ler e escrever. A criança precisa das ferramentas necessárias para essa aquisição. O "terreno" deve estar pronto para que ela possa se desenvolver. Observemos que, na imagem, o garoto apenas semeia, a terra já estava preparada (adubada). Não podemos esquecer que, a imagem desse éthos é, supostamente, voltada para o público infantojuvenil.

Voltando para a imagem, vemos que o menino não olha para o enunciatário, provocando uma debreagem enunciva e estabelecendo relação com o título do livro ("O menino que..."), que está na esfera enunciva na categoria da pessoa. Ele percorre a terra em sentido ascendente, em direção ao texto verbal, onde há o encontro figurativo do

19 Em diagramação, a diagonal serve como referencial na avaliação do espaço a ser ocupado pela ilustração e seus elementos constitutivos. 
semear com a palavra. Seu olhar segue este percurso também. Quanto à peneira, ela é um instrumento utilizado, de fato, para o plantio, num método tradicional (semeadura a lanço) para semear a terra. O garoto a utiliza para plantar as letras (muda) para que gerem palavras (frutos). É o poeta que está se formando, seguindo seu percurso, indo ao encontro de seu destino, do seu papel temático.

Identificamos a figura de um menino pelos traços infantis: uso de chapéu triangular (símbolo do universo lúdico infantil), uso de suspensório utilizado por meninos ${ }^{20}$ até meados do século $X X$, e o porte desengonçado. Esse objeto de época dialoga com a palavra "peraltagem", em desuso nos dias de hoje.

Com essa possibilidade de leitura, torna-se possível estabelecer relação entre a sarja (texto verbal/fruto) e o gorgorão (texto visual/muda). Através dos tecidos e de todas as categorias plásticas (de base e de relação) em que estão inseridas, homologando o texto verbal com o texto visual, essa relação forma um texto semi-simbólico em que a figuratividade está distribuída entre o verbal e o plástico.

No plano do conteúdo do texto verbal, a categoria semântica fundamental é inacabado x conclusivo, homologada com as categorias plásticas, mostrando o que os dois textos têm em comum.

\begin{tabular}{|c|c|c|c|}
\hline $\begin{array}{c}\text { PLANO DO } \\
\text { CONTEÚDO }\end{array}$ & \multicolumn{2}{|c|}{$\begin{array}{r}\text { INACABADO X } \\
\text { (semear) }\end{array}$} & $\begin{array}{c}\text { CONCLUSIVO } \\
\text { (frutos) }\end{array}$ \\
\hline PLANO DA & & Nervurado & Liso \\
EXPRESSÃO & Categoria eidética & Desenhos & Palavras \\
\cline { 2 - 4 } & Categoria cromática & Laranja claro & Laranja escuro \\
& & Mesclado & Puro \\
\hline
\end{tabular}

20 "Criado para segurar calções masculinos no século XVIII, o suspensório era inicialmente feito de cordão ou de tiras de tapeçaria [...]. Por volta de 1900, transformou-se em duas tiras unidas nas costas e presas às calças por botões e, mais tarde, por clipes de metal... As mulheres apropriam-se do suspensório nas décadas de 1960 e 1970, como parte da tendência UNISSEX". (O'HARA, Georgina. Enciclopédia da moda: de 1840 à década de 80, trad. Glória Maria de Mello Carvalho. São Paulo: Cia das Letras, 1992, p.260/261). 


\begin{tabular}{|l|l|l|l|}
\hline & Categoria topológica & Inferior & superior \\
\hline
\end{tabular}

Quadro 6. Homologação dos planos (conteúdo e expressão).

\section{Ilustração das páginas 30 e 31:}

Esta é a ilustração final da história, que mostra oito crianças brincando, não necessariamente umas com as outras, mas se divertindo com brinquedos e brincadeiras de infância. Um garoto solta pipa/papagaio, um casal de crianças gira o pião, uma dupla pula corda, uma menina se diverte com uma peneira, outra caminha sobre os pés de lata, e o último garoto brinca com um objeto que está na sua mão, não identificável pelo bordado.

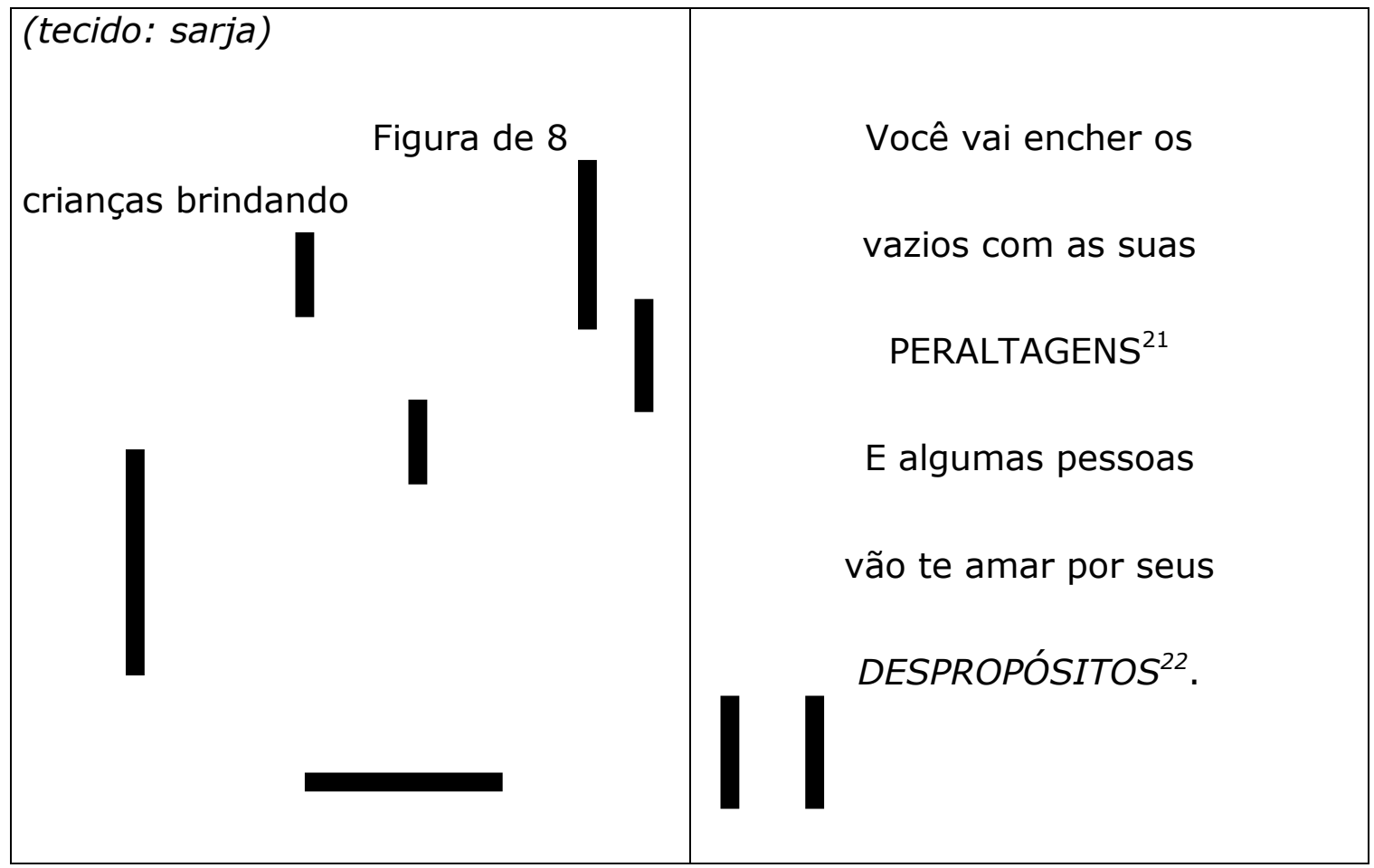

Esquema 2. Elementos topológicos e eidéticos.

Novamente 0 texto verbal e o texto visual dialogam, complementando-se, sem redundâncias. Enquanto o verbal fala do "fazer poético" e da sanção dada ao menino, o imagético mostra o brincar e como as crianças interagem nesse universo. Mas ambos estão na esfera

21 Palavra bordada.

22 Idem. 
do lúdico, porque ler e escrever são também atividades lúdicas oferecidas às crianças.

Observamos uma expansão de pessoa e de espaço do verbal para o visual, saindo do uno ("o menino") e indo para o múltiplo ("as crianças"). No texto escrito, a brincadeira gira em torno da palavra, enquanto as imagens amplificam o espaço mostrando vários tipos de brincadeiras e brinquedos.

A maneira de brincar com cada brinquedo vai depender do olhar da criança sobre o objeto. Há dois piões na imagem: o menino brinca com um deles soltando-o em direção ao chão, fazendo malabarismo; já a garota brinca rodando-o na palma da própria mão. Um menino e uma menina brincam de corda, ela opta por pular corda, ele prefere circulá-la.

O brincar pode ser individual ou coletivo, mas sempre divertido e prazeroso. Se escrever parece ser um ato solitário, compartilhar uma leitura, contar histórias, podem ser coletivos. Se as brincadeiras fazem uma criança interagir com outras, elas podem também individualizá-la. Uma criança pode decidir brincar sozinha com o objeto. Os textos (verbal e visual) mostram esta expansão e essa condensação. São as escolhas que determinam as esferas/os espaços.

Assim como ocorre uma debreagem de pessoa no verbal, o mesmo acontece no pictórico, pois duas crianças olham para o enunciatário, cada uma em uma página. Elas estão sorrindo e parecem (simulam) que estão convidando o leitor para conhecer e entrar nas brincadeiras.

Percebemos que há uma mudança na categoria espacial. Enquanto no verbal o espaço é enuncivo, não determinando em que lugar o narrador enuncia, na imagem ele demarca o espaço, colocando seus actantes em um lugar pontuado, num gramado. O espaço passa a ser concentrado (cheio de crianças), mas com sua extensão restrita. Essa condensação é topológica, pois se mantém do lado esquerdo e inferior da ilustração. Do lado direito fica o texto verbal, mas este tem seu espaço "invadido" e "tomado" pelo bordado. 
As palavras "peraltagens" e "despropósitos" deixam de ser tipográficas (iguais) para serem construídas artesanalmente (diferentes). Cada letra ganha um desenho específico. Por exemplo: o "P" é formado por uma menina em pé segurando um peixe com as duas mãos. E assim, cada letra vira uma brincadeira, uma diversão. Escrever torna-se prazeroso e criativo, pois cada um pode manifestar seus gostos e seus estilos. Criar não tem limites: enquanto a palavra "peraltagens" é escrita por desenhos de pessoas, peixes e brincadeiras de criança, a palavra "despropósitos" é desenhada apenas por linha (bordado simples).

Interessante observar que a palavra "peraltagens" é construída em letra de forma, com as letras distantes umas das outras, com tamanhos irregulares e não lineares, figurativizando o início da alfabetização, na qual a criança ainda não tem noção de espaço, de tamanho, nem de regras gramaticais (maiúsculas/minúsculas). Já a última palavra desta história, "despropósitos", é feita em cursiva, em que as letras se unem, com tamanho proporcional e seguindo numa linha reta, estilo típico de caligrafia. Ainda há pequenos tremores, mas a escrita é firme. A criança está alfabetizada, o processo está concluído.

Observamos que a comunicação visual ganha crédito ao acrescentar elementos de significação que proporcionam choques sensoriais, especialmente, visual e tátil, abrindo espaço para outras leituras. O verbal e o não-verbal caminham juntos, pois o texto poético pode apresentar características estruturais semelhantes às do texto pictórico, funcionando sincreticamente.

O design do livro é relevante por estabelecer relações e interações entre as imagens e o texto escrito. Aqui entra o papel do ilustrador que utiliza critérios e conceitos das artes plásticas e do design gráfico para desenvolver novas formas de se comunicar com as crianças. "O trabalho real de um designer de livro não é fazer as coisas parecerem "legais", diferentes ou bonitinhas. É descobrir como colocar uma letra ao lado da outra de modo que as palavras do autor pareçam saltar da página. O design de livro não se deleita com sua própria engenhosidade; é posto a 
serviço das palavras" (HENDEL, 2006, p. 3). Lê-se o texto escrito e o texto visual, acompanhando sua rima e o ritmo das frases, mas também as formas, as linhas, as cores e os desenhos, acrescentando elementos de significação, abrindo espaço para várias leituras.

A teoria semiótica mostra-se eficaz como ferramenta de análise para esse tipo de objeto por permitir uma leitura ampla e consistente, o que possibilita dialogar com outras linhas teóricas, respeitando o estatuto de cada linguagem.

Podemos afirmar que este livro pode ser tratado como um objeto de arte, caminhando para o estético, ao estreitar o diálogo entre a imagem visual e a palavra. A ilustração ganha uma posição de destaque ao estabelecer essa relação entre os elementos que compõem a obra, ao captar e recriar o verbal. 


\title{
2.3. Paixões, Estesias e Polifonia
}

\subsubsection{Diálogos e Paixões no rio de Ziraldo}

\begin{abstract}
"O rio que fazia uma volta atrás de nossa casa era a imagem de um vidro mole que fazia uma volta atrás de casa.

Passou um homem depois e disse: Essa volta que o rio faz por trás de sua casa se chama enseada.

Não era mais a imagem de uma cobra de vidro que fazia uma volta atrás da casa.

Era uma enseada.

Acho que o nome empobreceu a imagem."
\end{abstract}

Manoel de Barros ${ }^{23}$

O livro Menino do rio doce, de Ziraldo, publicado pela primeira vez em 1996, pela editora Companhia das Letrinhas, foi premiado, neste mesmo ano, pela Fundação Nacional do Livro Infantil e Juvenil (FNLIJ) nas seguintes categorias: melhor livro infantil, melhor projeto editorial e ilustrador revelação. A obra, amparada por ilustrações feitas pelo grupo Matizes, aponta um novo olhar sobre o mercado editorial destinado ao público infanto-juvenil.

A originalidade e a qualidade das ilustrações e dos projetos editoriais funcionam como estratégias mercadológicas para atrair o público jovem, tendo por objetivo resgatar o prazer pelo hábito da leitura nessa faixa etária. Além do encontro com a leitura, essas estratégias apresentam uma experiência estética tátil e visual, permitindo ao leitor realizar a entrada ao mundo das palavras de forma lúdica e prazerosa. Para o ilustrador Alan Powers (2008, p. 6), as crianças "não fazem uma separação tão automática entre forma e conteúdo, e podem estabelecer um vínculo emocional com um livro do mesmo modo como fariam com um

\footnotetext{
${ }^{23}$ BARROS, Manoel de. Livro das Ignorãças. $13^{\text {a }}$ edição. Rio de Janeiro: Record, 2007,
} p.25. 
brinquedo". Sobre as capas de livros infantis, o mesmo autor acrescenta: "a capa de livro ilustrada surgiu associada a crianças - e permaneceu uma constante da edição de obras de literatura infantil, sendo depois imitada pela indústria de livros" (POWERS, 2008, p. 10).

Selecionamos para a análise a décima segunda reimpressão desse livro, publicada em 2006. São vinte e oito páginas, com dezesseis ilustrações que ocupam dois terços das páginas duplas, separadas espacialmente do texto verbal. Nossa proposta é trabalhar com o texto verbal e o visual analisando as paixões presentes em toda a narrativa e que desencadeiam mudanças tímicas nos sujeitos garoto e rio, guiando seu percurso. Em seguida, analisamos as vozes que se apresentam nesse discurso, tendo como ferramenta teórica as questões de interdiscursividade e a intertextualidade. Essas questões serão observadas em relação a dois livros do autor norte-americano Mark Twain: As aventuras de Tom Sawyer (2007) e As aventuras de Huckleberry Finn (2005). Não podemos esquecer, porém, que as paixões permeiam tanto as experiências estéticas compartilhadas pelo próprio enunciado, quanto pela própria relação intertextual.

A depreensão dessa rede intertextual partiu da leitura da décima terceira página do livro Menino do rio doce. Nessa página, o autor abre o leque de referências ao citar personagens de obras clássicas da literatura infantil. Essa alusão, embora pontual no texto, possibilita uma significativa expansão de leitura, enriquecendo, inclusive, a própria compreensão da obra de Ziraldo. No segundo parágrafo dessa página, o narrador diz: "Todo menino do rio tem outro amigo do rio que é seu amigo também ou que do rio é irmão como Huckleberry e Tom" (ZIRALDO, 1996, p. 13).

Ao resgatar os personagens Huckleberry e Tom, o texto se expande, enriquecido pela bivocalidade e pela intertextualidade. Twain, considerado o mais importante escritor norte-americano de literatura infanto-juvenil, descreve a infância e a juventude de dois garotos, tendo o rio Mississipi como parceiro nessas vivências e aventuras. São histórias que contam o 
aprendizado e o amadurecimento desses meninos, moradores de cidades ribeirinhas, tendo suas vidas atravessadas pelo rio.

E por que essa escolha por parte do enunciador? Primeiro, porque ambos são livros destinados ao mesmo público-alvo, embora tenham sido escritos em épocas distintas. Segundo, nas obras dos dois autores as narrativas são construídas a partir do olhar dos garotos, tendo o rio como coadjuvante ou como destinador. Outro ponto pertinente à nossa análise é o diálogo com o texto visual, pois observamos que algumas frases e imagens no livro original de 1876 sobre Tom Sawyer, serviram de "inspiração" para a elaboração das ilustrações do livro brasileiro.

Quanto às paixões, nos parece pertinente incluí-las na análise por ser possível observar mudanças tímicas figurativizadas por objetos e pelas formas de contato do garoto com o rio. As ilustrações, inclusive, registram, através da experiência estésica, as sensações e os sentimentos, guiados pelo texto verbal.

Optamos por reproduzir abaixo, apenas o enunciado verbal da obra, respeitando as referências às páginas do original. Estas estão indicadas entre parênteses, antecipando o conteúdo de cada página.

\section{Livro: Menino do rio doce}

\section{(página 2)}

O menino tinha certeza de que havia nascido no dia em que viu o rio. Na sua memória não havia nada antes daquele dia.

\section{(página 3)}

O menino amou o rio pois acreditou que o rio havia também nascido no dia em que ele o viu. O menino olhava o rio: o rio era seu irmão.

\section{(página 5)}

$E$ ele entendeu que o rio era o rio e tudo aquilo que compunha o próprio rio: a pedra pontuda resistindo à correnteza e brincando de ilha no meio do rio; o peixe que saltou da água e o martim-pescador que mergulhou para pegar o peixe; a capivara pensante olhando para o infinito e o preá veloz desenhando sua fuga nas grimpas do capinzal; a fina garça branca feita de imóvel louça pousada em paz 
sobre o tronco, sala de espera do rio; a figueira debruçada figueira do rio doce - sobre o remanso - espelho - e seu reflexo no rio; a canoa passando com o homem remando no meio do rio...

\section{(página 6)}

E o menino aprendeu que a água - em gotas - da chuva era a refeição do rio e que quando chove muito eis que o rio engorda e engrossa e, guloso, engole a margem e vai levando a cerca e vai comendo a casa e vai tragando a árvore feita de raiz e galhos que passa devorada rumo ao fim do rio. O rio, quando chove muito, vai engolindo o mundo e de noite ronca sua digestão.

\section{(página 8)}

Se o sol, porém, castiga a terra onde o rio corre, o rio fica triste e seca sua água doce, inventando praias de areia branca (onde o menino-pirata enterrava seus tesouros). E secando, o rio mostra

\section{(página 9)}

suas entranhas de seixos rolados, de pedras que nascem e vão crescendo como cogumelos quando a água baixa. $O$ menino acreditava que a pedra pudesse ser coisa viva, vegetal.

\section{(página 10)}

O menino achava que prazer era conversar com o rio; e deitava o ouvido coladinho à terra na margem do rio pra ouvir os seus segredos, ouvir seus murmúrios e ouvir as histórias que todo rio tem e gosta de contar.

$\mathrm{E}$ dali, sentadinho na margem, o menino olhava a água do rio indo, indo e indo. E ficava horas a fio a mirar o horizonte lá onde o rio sumia; e sem que houvesse perguntas o menino se indagava (sem saber que se indagava): o que há além do rio? será o rio infinito?

E muitas vezes, lá longe, lá onde o rio sumia desenhava-se o arco-íris: portal do que será?

\section{(página 13)}

O rio é do menino e de quem habita o rio: o velho atrás do peixe que sobe e desce o rio pois sabe que é preciso mais pescar do que viver; o menino do rio que sabe que não há rio mais belo que o rio de sua aldeia; a mulher que lava seu branco lençol na beira do rio com os seus joelhos junto ao coração

Todo menino do rio tem outro amigo do rio que é seu amigo também ou que do rio é irmão como Huckleberry e Tom. É muito grande a família do povo que faz o rio.

\section{(página 15)}


O menino cortava o seu rio ao meio (como um pão se corta posto sobre a mesa) na sua jangada (barco de menino) e com a longa vara tocava bem fundo o fundo mais fundo do rio desvendado.

O rio também se cortava com os braços e ousadia (vitória era não deixar o canalão te levar na sua louca corrida); a margem era unida à outra pelo fio da coragem (ou porque nem se imaginava que assim não pudesse ser).

$\mathrm{E}$ era bom mergulhar na água turva do rio, deixar-se envolver por ela como por um macio, frio e úmido cobertor e ficar ali, quietinho, sem nunca querer sair...

\section{(página 16)}

Agora, é a canoa que leva o menino... O remo leve ia tocando a líquida pele do rio que sorria, marulhento, a cada toque do remo. E a canoa ia

\section{(página 17)}

- do jeito que mão cheia de carinho desliza branda - fazendo afagos na água companheira indo e vindo pelo corpo do rio. O remo guiando a canoa pra baixo e pra cima podia ser o entendimento da vida e de seu sentido pois só o rio sabe de onde ele vem, pra onde ele vai e o que faz aqui.

\section{(página 18)}

"Cuidado com a Cobra-Grande que na noite escura vai descer o rio pra te devorar."

O menino escutava as histórias do rio que não eram as histórias do rio (não era o rio que contava).

\section{(página 19)}

$\mathrm{E}$ por isso que o menino não temia a serpente que contavam - morava lá sob as águas do rio e que, em noite negra, o rio desceria com seus olhos de fogo - emiboitatá ${ }^{4}$ para devorar a Terra.

\section{(página 20)}

O rio - muito vivido - já ensinou pro menino que não existem sereias, Cobras-Grandes não existem e nem serpentes do rio na história de um rio amado - ainda que tal, temido - pois a serpente é o rio.

É o próprio rio a cobra que se enrosca na paisagem e faz curvas e volteios pra impedir que o proíbam de cumprir o seu destino: a curva é a vitória do rio.

\section{(página 22)}

${ }^{24}$ Boitatá é um mito indígena simbolizado por uma cobra de fogo ou de luz com dois olhos grandes, ou por um touro que lança fogo pelas ventas. A palavra tupi se escrevia mboitatá (1876), mas o autor aqui optou por escrever emiboitatá (Fonte: Dicionário Houaiss). No Dicionário Aurélio, consta a palavra "mboi", de origem tupi, que significa cobra. 
Não teme o rio o menino mesmo quando suas águas engolem o outro menino companheiro das folganças feitas de lama e respingos, feitas de jogo e paixão.

O menino que se afoga, que mergulha e que não volta e se aconchega nas águas fundas e tristes do rio vai ser achado, somente, quando a tábua flutuante com uma vela acesa em cima descer o rio e parar em algum remanso, dizendo: "Ele está aqui dormindo o seu sono sem retorno" - pois que o rio, às vezes, faz sua misteriosa vontade.

\section{(página 25)}

E com o seu amigo morto nas águas do rio-irmão o menino aprendeu que assim vivem os rios. E o menino chorou um rio de lágrimas, alimento do rio que vai passando. Como tudo vai passar.

O menino brincava no rio, o menino brincava com o rio como brincam os moleques parceiros do mesmo tempo, pois que o rio tem a idade de quem brinca, vive ou morre no rio que, passando sob a ponte, é o tempo feito de água. Vai indo o tempo, vai indo... vem o rio, o rio vai e o menino tem que ir. Cada um passa a seu modo.

\section{(página 26)}

O menino foi crescendo como o rio, quando chove, só que água sem retorno. E só aí descobriu que, menino, olhava menos para o lado de onde vinha o rio descendo a serra. Seus olhos estavam sempre voltados para o poente, para onde ia o rio, flecha apontada prum alvo que o menino não via.

E, no ar, uma pergunta nunca feita (todo dia): "Onde vou cravar meu rio?".

O rio ensinou, porém, que, um dia, o menino ia dividir-se em dois e, do seu jeito, partir (pois que pelo rio vai-se para o mundo): os braços feitos braçada, os pés botados na estrada, a sua estrada é o rio.

\section{(página 29)}

O rio nasce - doce - na gorda barriga da montanha e vai morrer na praia (do lado de cá).

Todo dia o rio nasce, todo dia o rio morre, todo dia o rio parte, chega o rio, todo dia, ao seu destino de sal. "Vem comigo ao meu destino!", diz o rio ao seu menino que, agora, quase homem parte-se para partir.

"O mar é o meu começo", adivinhou o menino (ou o rio lhe ensinou).

E o rio repete: "Vem!".

E dizendo isso o rio se desmancha no azul da água salgada do mar. Onde a história do homem que veio vindo com o rio - menino feito de água - agora vai começar... (ZIRALDO, 1996, p.2-29). 


\subsubsection{As paixões pelos sentidos}

O livro relata a amizade entre um garoto e o rio que atravessa sua pequena cidade e, naturalmente, sua vida. Observaremos nesta análise, a importância dos sentidos (visão, audição, tato e paladar) e do componente sinestésico, apreendidos como informantes do mundo exterior e como elementos que capacitam o sujeito na construção afetiva. "O narrador isola [...] e constitui como objetos funcionais esses fragmentos táteis, olfativos, auditivos, visuais, que intervêm inesperadamente no mundo" (BERTRAND, 2003, p. 252).

O garoto vai apreendendo os segredos pelos sentidos e, assim, passa a criar uma cumplicidade com o rio. Verificamos a presença de experiências físicas que levam a mudanças tímicas. São essas experiências que vão permitir ao garoto adquirir a competência necessária para realizar a performance. O garoto é um sujeito de estado que tem sua competência modal alterada pelo rio, seu destinador. Dessa forma, procuramos depreender os modos de significação.

O essencial das mudanças, de fato, decorre do lugar central que ocupam no caso os verbos de sensação, ligados ao sujeito (doravante anônimo) que é seu agente: ver, tocar, ouvir. A ação do homem e o cenário em que se encontra já não estão separados: ele se tornou-ator-participante. (BERTRAND, 2003, p. 199).

O texto descreve, primeiramente, a construção afetiva do menino ao perceber, desde pequeno, a presença do rio (ZIRALDO, 1996, p. 2-3). É pela visão que ele, além de adquirir a capacidade de olhar as coisas e pessoas, adquire também a competência para reconhecer coisas e interpretá-las.

O primeiro sentido despertado é o da visão. Logo no início da história esse sentido é descrito: "O menino amou ${ }^{25}$ o rio pois acreditou

\footnotetext{
${ }^{25}$ Grifo nosso.
} 
que o rio havia também nascido no dia em que ele o viu ${ }^{26 \prime \prime}$ (p. 3). Temos um sujeito modalizado e patemizado diante do seu encantamento pelo rio. Por meio dessa relação entre o menino e o rio, "o objeto estético se transforma em ator sintático que, manifestando de tal forma sua 'pregnância', avança sobre o sujeito-observador" (GREIMAS, 2002, p. 34).

Essa criança mantém seu olhar sobre o rio, observando seus movimentos, sua constituição física e os elementos que o compõe, tais como: a pedra pontuda no meio do rio; o homem pescando; os animais que dele vivem ou que dele se alimentam; a vegetação que o circunda e o corta. A medida que o olhar do menino avança, ele segue o percurso "do rio indo, indo e indo" num horizonte sem fim. Segundo Greimas (2002, p. $35)$, o avanço do olhar é "a forma figurativa do desejo". Ao conhecer o rio pela visão o garoto desperta a paixão benevolente do amor. O garoto a tudo observa e, permeado pelo desejo contínuo de saber sobre o rio, cada vez mais ele vai aprendendo e apreendendo sentidos. Sua aquisição é extensiva e durativa, pois, para que essa paixão se instale, ela demanda tempo e abrangência. A aquisição da competência do sujeito para obter o objeto de valor almejado - o saber e o amadurecimento - começa por esse sentido.

Ainda pelo olhar, o garoto vê o rio expor suas profundezas e a sua vulnerabilidade ao secar e mostrar suas entranhas. O narrador descreve 0 estado passional do rio: "se o sol, porém, castiga a terra onde o rio corre, o rio fica triste ${ }^{27}$ e seca sua água doce", [...] E secando, o rio mostra suas entranhas de seixos rolados $^{28 "}$ (ZIRALDO, 1996, p. 8-9). A definição dada pelo dicionário Aurélio (2009) para a palavra "entranhas" é significativa para depreendermos seu estado patêmico: ventre materno; caráter, índole (figurativo); sentimento, coração; profundidade, profundeza.

O rio está completamente exposto. E, assim, ao submeter sua "imagem projetada [...] à apreciação, ou ao juízo de outrem, significa colocar-se em situação de "lado fraco", na qual "alguém pode ser atacado

\footnotetext{
${ }^{26}$ Idem.

${ }^{27}$ Grifo nosso.

${ }^{28}$ Idem.
} 
ou ferido" (HARKOT-DE-LA-TAILLE, 1999, p. 53). Entretanto, esse é um sujeito detentor de poder, capaz de despertar admiração e respeito. Sendo assim, "um sujeito dotado de poder poderá não impingir um sentimento de exposição [...], mas medo" (HARKOT-DE-LA-TAILLE, 1999, p. 54).

Estamos diante do rio como um sujeito destinador (S1), modalizado pelo medo. "S1 reconhece-se na posição de actante-objeto e, como tal, submete-se a S2 - seus pensamentos, seus juízos -; daí o desconforto característico da exposição" (HARKOT-DE-LA-TAILLE, 1999, p. 49). O rio, que até então se mostrava imponente, expõem seus "seixos rolados", isto é, mesmo sem querer mostrar - querer-não-ser-visto ou não-querer-servisto - se vê exposto, revelado, descoberto. Sua intimidade é violada pela exposição.

\footnotetext{
Mostrar-se torna o sujeito vulnerável, na medida em que teme que a leitura de sua imagem projetada não coincida com a "boa imagem" que tem para si. Desse modo, vem à tona um medo "em segundo grau": no caso específico de um sujeito que é visto, trata-se do medo da opinião de outrem. $E$ eis que novamente chegamos ao outro. Quem é, afinal, esse outro, cuja opinião é tão prezada (HARKOT-DE-LATAILLE, 1999, p. 53).
}

O garoto, ao exercer o papel de destinador-julgador, concede ao rio uma sanção pragmática positiva. O menino compreende que o rio também tem "fraquezas", e a sua admiração e encanto por ele, permanecem. "A estima de S1 por S2 é um fator legitimador do último como expectador, para o primeiro (HARKOT-DE-LA-TAILLE, 1999, p. 55). O garoto logo transforma a tristeza do rio em diversão, criando um mundo encantado de piratas que só as crianças sabem fazer. E, quando o rio enche, as brincadeiras continuam com mergulhos e passeios de balsa ou de canoa. Rio e menino são agora sujeitos em sincretismo, sendo restabelecidos seus papéis actanciais.

O garoto olha o rio e procura ver até onde esse rio vai. 0 conhecimento segue sem parar, sendo abertas na narrativa todas as 
portas do desconhecido ("...onde o rio sumia desenhava-se o arco-íris: portal do que será?" ZIRALDO, 1996, p. 10). Mas o menino só chegará lá quando for um sujeito competente, um sujeito do fazer. Para isso, ele busca no seu destinador o conhecimento necessário para torná-lo apto a obter o objeto de valor almejado.

Pela sequência narrativa, o segundo sentido a ser explorado no texto é o tato. O garoto que, até então, agia como um sujeito observador, mantendo uma relação contemplativa, passa a interagir com o rio. É pelo contato da pele que ele vai sentir o mundo e essa experiência the permitirá expressar suas necessidades, suas vontades e manifestar reações físicas de prazer ou de insatisfação.

No conto, o primeiro contato físico do garoto com o rio ocorre quando a seca expõe as entranhas do rio, evidenciado o que a água esconde: os bancos de areia. O garoto logo passa a interagir com o rio ao enterrar seus tesouros na areia e a brincar de pirata.

Assim, surgem a cumplicidade e a amizade entre eles. Mesmo com o rio triste, o garoto, como amigo, encontra maneiras de fazer o rio se divertir e esquecer suas limitações naturais. Ele restabelece, de uma maneira lúdica, pelo tato, a condição afetiva do rio que volta a ser alegre. O rio é querido não somente por fornecer alimentos à população - meio de sobrevivência e de trabalho (pesca, lavar roupa) - mas, simplesmente, porque "o rio era o rio e tudo aquilo que compunha o rio". Segundo Greimas (2002, p. 36), "o tato se situa entre as ordens sensoriais mais profundas, ela exprime proxemicamente a intimidade optimal e manifesta, sobre o plano cognitivo, a vontade de conjunção total".

Mais adiante, com o rio encorpado, isto é, coberto de água, o garoto volta e desta vez busca e encontra aconchego e segurança. Vejamos o que o texto diz sobre essas experiências: "E era bom mergulhar na água turva do rio, deixar-se envolver por ela como por um macio, frio e úmido cobertor e ficar ali, quietinho, sem nunca querer sair..." (ZIRALDO, 1996, p. 15). Há uma troca afetiva entre eles e cada um supre a necessidade do outro. 
O tato permite ao menino estar em total conjunção com o objeto rio, podendo compartilhar seu mundo, brincar e obter dele a sua retribuição afetiva. O tato ratifica o saber adquirido pelo garoto. Vemos que há uma "relação entre sujeito e objeto articulada pelo corpo" (OLIVEIRA, 2002, p. 13). Ele descreve o rio como uma pessoa de corpo e pele, que gosta de ser acariciado: "- do jeito que mão cheia de carinho desliza branda fazendo afagos na água companheira indo e vindo pelo corpo do rio".

O rio também é tocado de outras maneiras pelo garoto, com materiais diferentes, tais como a vara, ou o remo. Cada um deles desencadeia no rio sensações e, no menino, conhecimento. Vamos a eles:

a) Pela longa vara: o menino corta o rio ao meio e consegue tocar "bem fundo o fundo mais fundo do rio desvendado". Nesse contato, ele chega ao âmago do rio. Ele chega ao centro, a parte mais íntima, na essência do rio ou, até mesmo, na sua "alma".

b) Pelo remo: o garoto toca "a líquida pele do rio". O rio gosta e retribui com um sorriso "marulhento". O rio sente a "mão cheia de carinho", deslizando suavemente e "fazendo afagos na água companheira". Há uma troca de intimidade, de cumplicidade e de carinho.

O rio emite um som: "sorria marulhento". Do contato físico, seguese à audição. O rio manifesta seu prazer ao emitir um ruído de ondas, agitando-se ao ser tocado. Como diz Harkot-de-la-Taille (1999, p. 61), "toda paixão pressupõe uma agitação no horizonte tensivo, anterior a qualquer polarização, a inquietude".

Acrescido de mais um sentido, os laços da amizade são fortalecidos e eles se tornam amigos confidentes. O menino aprende a ouvir as histórias que o rio tem para lhe contar, ele deita "o ouvido coladinho à terra na margem do rio pra ouvir...". Ainda há a necessidade do tato, mas outro órgão físico passa também a fazer essa mediação. 
Ouvindo o rio, o garoto "logo aprende que as histórias contadas pelos moradores não passam de lendas e superstições". O rio também compartilha com ele segredos, murmúrios e histórias que todo rio tem e gosta de contar. Não importava à criança como o rio se comunicava com ele, pois ele tinha prazer em conversar com o rio.

Eles selam laços de amizade e de cumplicidade. O garoto não acreditava nas histórias contadas por outras pessoas sobre o rio, se essas não fossem confirmadas por ele. O rio era um destinador confiável, pois parecia e era sincero com o garoto.

\footnotetext{
"O rio - muito vivido - já ensinou pro menino que não existem sereias, Cobras-Grandes não existem e nem serpentes do rio na história de um rio amado". Mas aprende, também, que o rio é temido pela sua própria natureza, pois "é o próprio rio a cobra que enrosca na paisagem e faz curvas e volteios para impedir que o proíbam de cumprir o seu destino..." (ZIRALDO, 1996, p. 20).
}

A presença do traço gustativo gera mudanças tímicas nos dois sujeitos: a) no garoto, que se defronta com a gula do rio, que arrasta casas e tudo mais que atravessa o seu caminho no período das enchentes; b) e no próprio rio, ao agir com violência e irracionalidade.

Embora fique claro que estamos falando da fome metafórica, é inegável que essa ação do rio provoca transformações tímicas no garoto, como vemos no decorrer da análise.

O garoto apenas descreve a ação do rio, ao agir como um espectador, uma testemunha. O rio, um sujeito hiperbolizado, pelo contrário, segue um percurso passional de uma fúria desmedida e alastradora. "A paixão é aquela do acontecimento: o acontecimento não é acabado, ele advém e afeta aquilo que está diante dele, para quem ou em quem ele advém" (FONTANILLE, 2007, p. 188).

Mais do que isso, observamos um frenesi do rio gerado pelo processo da refeição. Há uma forte pulsação, uma aceleração que prossegue até quando a "noite ronca sua digestão". Vemos um acúmulo, uma densidade das coisas, um transbordamento: 
- de gota em gota a chuva abunda;

- o rio engorda e engrossa;

- uma refeição em que os alimentos não são mastigados, são engolidos, devorados;

- e sua abrangência é grande, pois arrasta e traga tudo que atravessa seu caminho: casa, cerca, árvore, raiz e galhos.

O rio vai fazer sua refeição, começando pelas gotas de água das chuvas. Segundo o dicionário do Aurélio (2009), a palavra "refeição" pode ser entendida com o "ato de refazer as forças, de alimentar-se". Mas, de forma desmedida e voraz, o rio, com gula, isto é, com "apego excessivo a boas iguarias", vai devorando, engolindo e tragando tudo o que encontra, engordando e engrossando, "rumo ao fim do rio". Os alimentos entram pela boca e vão direto para o estômago, sem passar pelo processo de digestão, que transforma o "alimento em substâncias absorvíveis e assimiláveis". Greimas e Fontanille (2003, p. 165) explicam que "a aspectualização interna de cada ocorrência proporciona à manifestação passional uma pulsação que regula as tensões e distensões do processo passional propiamente dito".

Essa fúria descontrolada - que é pontual na aspectualidade, pois é uma variante da cólera - só cessa quando o próprio rio tem que enfrentar a sua digestão: uma digestão difícil, com ronco e até mesmo agonizante. O rio emite um som grave e contínuo de desconforto. A palavra "noite" expande essa análise, pois pode também ser entendida, figurativamente, segundo o dicionário Aurélio (2009), como "sofrimento" e "tristeza". Sendo a gula um pecado, o castigo do rio é a sua própria digestão.

E o menino aprendeu que a água - em gotas - da chuva era a refeição do rio e que quando chove muito eis que o rio engorda e engrossa e, guloso, engole a margem e vai levando a cerca e vai comendo a casa e vai tragando a árvore feita de raiz e galhos que passa devorada rumo ao 
fim do rio. O rio, quando chove muito, vai engolindo o mundo e de noite ronca sua digestão (ZIRALDO, 1996, p. 6).

O menino a tudo assiste e apenas descreve. Não condena o rio ou com ele se rebela. "Todas as paixões são, então, julgadas em função da "manutenção" ou da "postura" que permitem controlar suas manifestações" (GREIMAS; FONTANILLE, 1993, p. 148). O menino, por conhecer o rio, sabe que logo será restabelecida a ordem. Em nenhum momento ele manifesta sequer a revolta, pois acredita nos valores do seu destinador.

Novamente, pela boca do rio, mais uma experiência de perda - mas não de medo - é enfrentada pelo garoto. "Suas águas engolem o outro menino companheiro de folganças". Ele compreende que, às vezes, "o rio faz sua misteriosa vontade" (ZIRALDO, 1996, p. 24).

O garoto aprende a lidar com as perdas através da voraz fome ou da vontade misteriosa imposta pelo rio. O garoto não o teme, apenas se resigna e chora pelo amigo que morreu. "E com o seu amigo morto nas águas do rio-irmão o menino aprendeu que assim vivem os rios. E o menino chorou um rio de lágrimas..." (ZIRALDO, 1996, p, 25). Aqui também não há julgamento moral, pois esse tipo de julgamento estabelece "limiares numa escala de intensidade, escala orientada que permite concluir pelo excesso ou pela insuficiência, conforme nos coloquemos além ou aquém do limiar" (GREIMAS; FONTANILLE, 1993, p. 145).

Para restabelecer a sua conjunção com o rio, o garoto fornece o que o rio mais precisa: água. Esse "rio de lágrimas" rompe o estado de sofrimento e restabelece a confiança e a alegria, pois "tudo vai passar". A liquidação da falta fiduciária pela tristeza não é durativa e é restabelecida pelas lágrimas.

É interessante descrever que as gotas de chuva abrem o apetite voraz do rio, em oposição as gotas de lágrimas que apaziguam esse mesmo rio. Temos, portanto, dois tipos de efeitos passionais: a) gotas que patemizam exacerbadamente, numa cólera descontrolada e 
devastadora; b) gotas que restabelecem o estado passional de serenidade.

Os conectores isotópicos figurativos, sendo elementos de significação que designam a interação das figuras, asseguram "a coesão semântica e a homogeneidade do discurso enunciado" (BERTRAND, 2003, p. 186). São esses traços sensoriais que atuam no desenvolvimento da narrativa oferecendo elementos de coerência e de compreensão textual. Como conectores, abrem uma "significação inicial para um novo universo de sentido, e instalando assim duas leituras coexistentes e parcialmente concorrentes de uma mesma significação" (BERTRAND, 2003, p. 189).

Vejamos no quadro abaixo, os traços sensoriais apreendidos no enunciado:

\begin{tabular}{|c|l|}
\hline TÁTEIS & $\begin{array}{l}\text { Macio, frio e úmido cobertor; } \\
\text { tocando (a líquida pele do rio); } \\
\text { mão cheia de carinho desliza branda... pelo corpo do rio; } \\
\text { a longa vara tocava bem fundo o fundo mais fundo do rio; } \\
\text { e se aconchega nas águas. }\end{array}$ \\
\hline VISUAIS & olhava (o rio); mirar; belo; olhos voltados para o poente. \\
\hline SONOROS & marulhento; ouvir (segredos e histórias); murmúrios. \\
\hline GUSTATIVAS & água doce; engole; refeição, lágrimas, sal. \\
\hline
\end{tabular}

Quadro 7. Traços sensoriais apreendidos no enunciado.

O texto não mostra nenhuma fratura, mas apenas tensões que chegam rapidamente ao relaxamento pelo "percurso da confiança no simulacro interno do sujeito" (HARKOT-DE-LA-TAILLE, 1999, p. 104). Não há mudança de referente, pois a estima do garoto pelo rio é "manifestada de maneira contínua e tensiva" (GREIMAS; FONTANILLE, 1993, p. 168).

O garoto cresce e, pela competência adquirida (saber-fazer) pelo seu destinador-rio, pode, agora, enfrentar o seu grande desafio: a cidade grande. Com tudo o que ele aprendeu, nada teme e decide enfrentar o desconhecido. 
Seu contrato fiduciário com o rio-irmão é mantido, mesmo que cada um tenha tido que seguir seu caminho, seu destino. $O$ rio, sabendo que cumpriu seu papel, "se desmancha no azul da água salgada do mar". O menino entende e diz: "o mar é o meu começo" (ZIRALDO, 1996, p. 29).

\subsubsection{A estesia em movimento}

Focamos, nesta seção, as experiências estésicas - isto é, os eventos sensoriais da percepção -, do garoto e do rio. Observamos que elas estão relacionadas a expansões e condensações, figurativizadas pelos tipos de transportes marítimos. Essas expansões e condensações têm como intuito mostrar o amadurecimento e o crescimento do menino, e, ainda, apresentar a profundidade/superficialidade quanto à forma de contato físico/afetivo do menino com o rio. Segundo Bertrand (2003, p. 253), "a síntese das percepções consiste em compor entre si os fragmentos percebidos, animando-os e transformando-os em objetos identificáveis por estarem unificados no tecido das percepções".

À medida que o menino vai conhecendo e criando uma amizade com o rio, os objetos intermedeiam esse contato e seus afetos. Esses objetos sofrem alterações quanto ao seu porte e funcionalidade durante a narrativa, e o contato físico do garoto com o rio passa por significativas mudanças. Vemos que "a figuratividade permite, assim, localizar no discurso esse efeito de sentido particular que consiste em tornar sensível a realidade sensível" (BERTRAND, 2003, p. 154).

O primeiro meio de transporte usado pelo garoto na história é uma jangada, descrita no texto como "barco de menino". Para fazê-la movimentar na água, o menino utiliza uma longa vara, "tocando bem fundo o fundo mais fundo do rio desvendado" (ZIRALDO, 1996, p. 15). Segundo o dicionário Aurélio (2009), vara é um "ramo fino e flexível" ou "qualquer haste delgada". De forma delicada, porém profunda, a longa 
vara vai intermediando o contato mais íntimo, permitindo ao garoto conhecer e entender as características próprias daquele rio-irmão.

Quanto à jangada, vemos que ela é de porte pequeno e de estrutura artesanal, uma "construção ligeira, em forma de grade" (Aurélio, 2009). Esse tipo de embarcação é bastante restritivo quanto à sua funcionalidade, pois, além de somente poder carregar poucas pessoas não mais do que quatro -, só pode ser utilizado em rios e mares com pouca profundidade ${ }^{29}$. Geralmente seu uso restringe-se a travessias ou a pesca de subsistência. Mas é exatamente num barco tão rústico e simples, um "barco de menino", como define o narrador, que se dá a maior proximidade entre os dois. São todos elementos em construção: um sujeito em crescimento/amadurecimento, um transporte rudimentar e um rio sendo desvendado.

Na sequência, a criança passa a usar uma canoa com um remo. Essa embarcação é mais elaborada, comportando, inclusive, um número maior de pessoas. Ela pode ser feita artesanalmente ou não, mas sua função é mais ampla socialmente, pois serve como transporte, e economicamente, ao avançar mar adentro, para a pesca.

Nessa canoa o garoto toca com leveza o rio, que the retribui o afago com um "sorriso marulhento". A cada toque do remo, o rio percebe seu carinho. Embora o toque seja mais superficial, não atingindo as profundezas do rio, há cumplicidade entre eles. Eles estão estabelecendo aqui a amizade e o amor.

O terceiro e último transporte que aparece não é citado no texto verbal, aparecendo apenas no texto visual (penúltima ilustração do livro). Ele aparece no momento em que é descrito que o menino, ao tornar-se um rapaz, deve partir para o seu destino. O texto verbal fala do crescimento do garoto, dos seus novos desafios e do seu destino. $O$ pictórico mostra um barco a vapor, com um comandante a bordo segurando o timão e algumas pessoas dentro da embarcação acenando

\footnotetext{
${ }^{29}$ Não confundir com a "jangada do alto", de grande extensão, que chega a medir oito metros de comprimento, própria para navegação em alto-mar.
} 
para as pessoas que estão na terra. O garoto está na margem do rio, de calça comprida, segurando uma mala, abraçado por uma mulher.

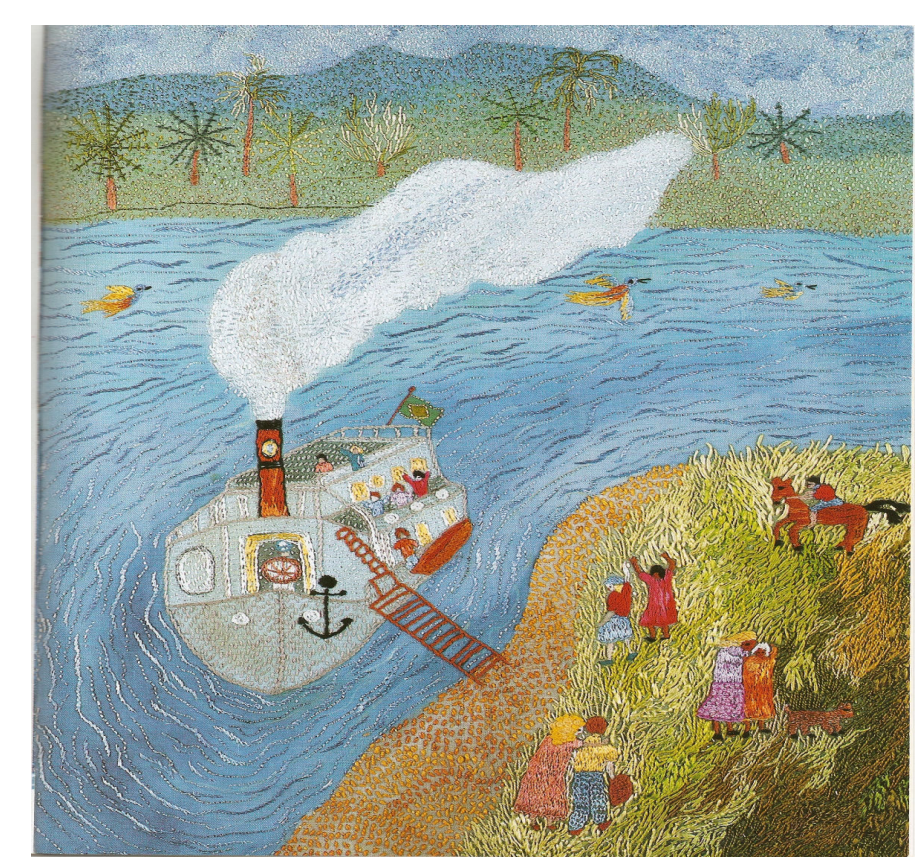

Ilustração 31. O menino partindo. In: ZIRALDO. Menino do rio doce.

$12^{\mathrm{a}}$ reimpressão. São Paulo: Companhia das Letrinhas, 2006, p. $27^{30}$.

Pelos dois enunciados, verbal e visual, pode-se concluir que o agora rapaz está partindo, deixando sua cidade e o rio que a corta. A amizade entre ele e o rio-irmão foi selada, mas a separação é iminente. Ele não mais toca/sente o rio, cria-se um distanciamento físico, mas não afetivo.

O contato, então, é feito por um motor e suas pás, que obedecem aos comandos de uma máquina. A direção e o destino estão em outras mãos, na do comandante de bordo. O barco a vapor figurativiza 0 crescimento e o amadurecimento do garoto. E mais uma leitura se faz: pelo barco chega o momento da separação e da despedida, em que cada um - o garoto e o rio - deve seguir seu destino. Vemos que "quanto mais distante do centro dêitico (maior extensidade), menor a intensidade sensível - sensível significando, no caso, "perceptiva" e "tímica" simultaneamente; quanto mais próximo do centro dêitico (menor extensidade), maior o impacto sensível, logo a intensidade (LOPES, 2006, p. 11).

${ }^{30}$ (Cf. Anexos, ilustrações em tamanho original). 
Embora a separação entre o menino e o rio seja o que o destino thes reserva, essa cisão não representa uma ruptura completa, pois a memória afetiva do garoto guardará tudo o que o rio lhe ensinou e todas as experiências compartilhadas juntos. Agora, cada um vai seguir seu destino: o rio, vencido pelo mar; e o rapaz, enfrentando os desafios da cidade grande.

Ao partir, segundo o texto imagético (última ilustração), o menino segue seu caminho sozinho em um pequeno barco. O rapaz vai ao encontro da vastidão do mar. Se o rio corta sua pequena cidade, ele agora vai se defrontar com o grande mar que cerca uma cidade grande, com prédios altos e acinzentados. Temos aqui três actantes posicionais: o garoto - a fonte que apreende e sente -, a cidade e o mar - funcionando como alvos que são/serão apreendidos - e, o rio, exercendo a função de actante de controle ao regular o acesso da fonte ao seu alvo.

Observa-se que o texto verbal deixa várias lacunas de leitura que são preenchidas pelo texto visual. Mais do que dialogar, as duas categorias (enunciado verbal e enunciado visual) se complementam. Os componentes plásticos, por exemplo, ampliam e direcionam, em vários momentos, a compreensão do texto verbal. O sincretismo ocorre graças à formação de uma enunciação única, pois "confere ao arranjo das partes e às múltiplas manifestações de linguagem um caráter de unidade" (TEIXEIRA, sd, p. 11).

$\mathrm{Na}$ última ilustração do livro, por exemplo, as categorias de base constituinte (cromática) e constituídas (eidética e topológica) - confirmam sua importância ao oferecer elementos de significação e de percepção. Essa, por sinal, "está reduzida ao que ela é efetivamente na realidade, ou seja, a fragmentos isoláveis e isolados - os esboços - que ainda não têm nem nome, nem valor" (BERTRAND, 2003, p. 253). Vejamos: 


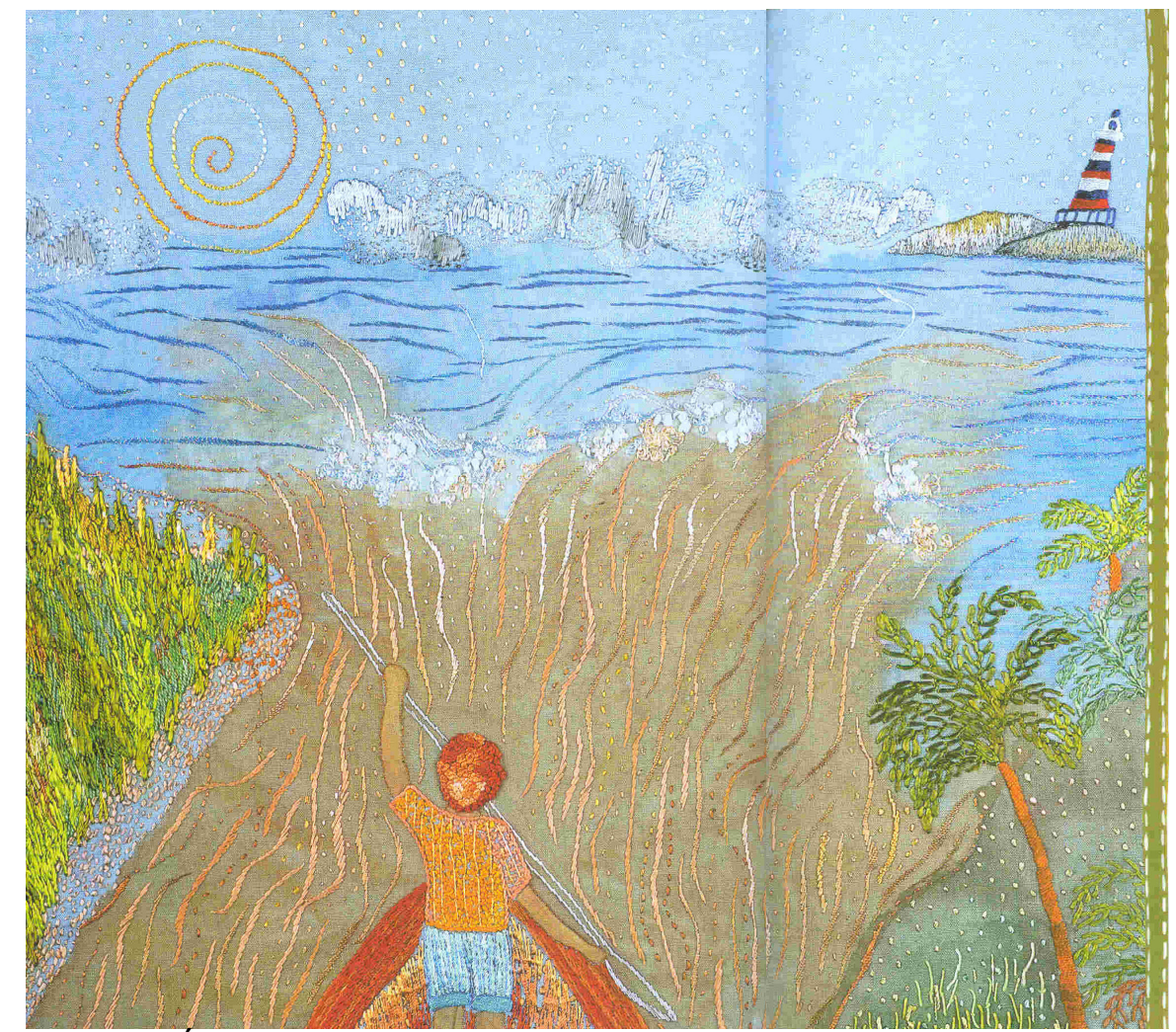

Ilustração 32. Última ilustração do livro: o garoto e o rio seguem seus destinos. In: ZIRALDO. Menino do rio doce. $12^{\mathrm{a}}$ reimpressão. São Paulo: Companhia das Letrinhas, 2006, p. 28-29.

Quando rapaz, partindo para a cidade grande pelo rio e pelo mar, o menino se depara com uma cidade acinzentada. Sua visão frontal é monocromática, com uma sequência de prédios suspensos, mal definidos e nublados, criando um paredão ao fundo, um bloqueio ao mar. $\mathrm{O}$ azul aqui utilizado é de um tom frio, misturado ao preto, criando uma imagem nebulosa e triste. O efeito de sentido é de aspereza e frieza, um lugar sem vida, apenas um extenso bloco cinza na horizontal.

Ainda na questão cromática, a cidade grande sofre duas quebras com a presença: a) à esquerda, do enorme sol que traz luminosidade com seus pontilhados amarelados e alaranjados; b) à direita, um farol tricolor. São pontos luminosos diante da extensa faixa acinzentada que se prolonga com o céu na mesma cor/tonalidade de azul. O sol quebra os concretos da cidade e insere um elemento da natureza, suavizando a monotonia do olhar sobre a cidade. O farol - construído sobre uma ilhota, separado da cidade - tem a função de guiar ou de ser um ponto de referência, de direção para o garoto que vai chegar na cidade pelo rio- 
mar. Porém, esses pontos de luz não são suficientes para iluminar, predominando, assim, o acinzentado opaco.

A parte superior da imagem concentra os dados acima citados. $\mathrm{Na}$ parte inferior, temos os desenhos do rio e da vegetação da cidade ribeirinha. O verde, em várias nuances, predomina nesse espaço, cortado ao meio pelo rio barrento, e pelo garoto dentro de um barco.

Ocorre aqui uma mudança significativa com o rio: ele, que durante toda a narrativa (imagética) era azul, torna-se, na última ilustração, marrom, contrastando com o azul do mar. E por mais que ele tente invadir o mar, ele é absorvido ou, como o próprio texto verbal diz, ele "vai morrer na praia". O doce do rio é vencido pelo sal do mar ("chega o rio, todo dia, ao seu destino de sal"). O menino a tudo assiste, pois seu barco, assim como ele, estão inseridos nessa narrativa.

$\mathrm{Na}$ questão topológica da cidade, nota-se que a mesma está completamente separada do mar. Ela se encontra suspensa, sobre morros, criando um efeito de montanha-russa (sobe-e-desce, sobe-edesce,...), com dois planos de profundidade: a) na parte frontal, predominam os prédios feitos de linhas verticais; b) ao fundo, com formas arredondadas e preenchidas por pontilhados, a presença de mais morros. Tem-se a impressão de que a cidade não interage com o mar ou com qualquer outro elemento da natureza. O sol, por exemplo, está entre dois blocos da cidade, mas não dentro da cidade. Há um distanciamento físico entre eles. Na categoria dimensão, notamos a representação da cidade em pequena proporção. Voltaremos a esse ponto mais adiante.

O garoto e o rio estão localizados na parte inferior da ilustração, que ocupa um espaço maior, cerca de dois terços da página. Essa área é dividida em três colunas verticais compostas: a) pela vegetação; b) pelo rio-mar-garoto; c) pela vegetação novamente. Vejamos como esses espaços estão preenchidos na ilustração, visualizando, assim, a categoria topológica relacionada às formas e às cores, acrescentando as direções (sentido) do mar e do rio: 


\section{cidade cidade dividindo espaço com os morros}

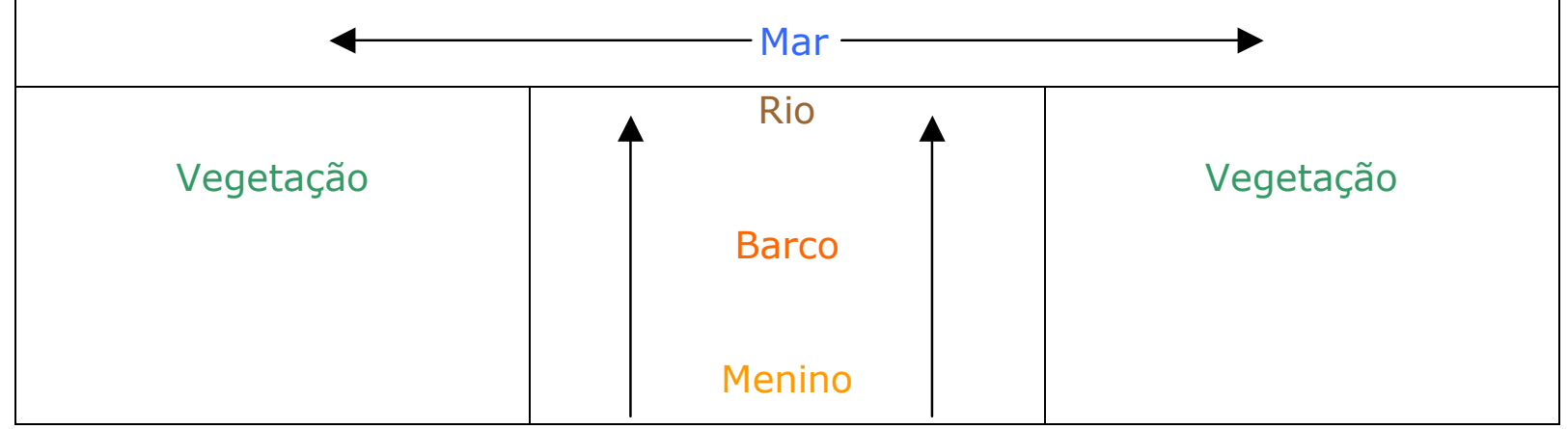

Esquema 3. Distribuição dos elementos topológicos, cromáticos e eidéticos na ilustração do livro Menino do rio doce ${ }^{31}$.

O menino, com suas vestes de criança, está de costas para a sua pequena cidade ribeirinha e para o rio, mas de frente, com o rosto direcionado para o mar e para a cidade grande. Seu corpo e seu barco estão recortados. A imagem "começa" mostrando a ponta da embarcação e o garoto a partir das pernas. Seus pés não aparecem, permitindo fazer uma leitura de que suas raízes (pés) ficaram fincadas na sua terra natal.

Outro ponto pertinente para a análise é a relação de direção. Enquanto o rio segue seu percurso no sentido vertical ascendente, o mar segue na horizontal, tanto para a direita quanto para a esquerda. O mar se expande, o rio se condensa. Mas a resistência do rio, embora saiba que seu destino é morrer ao se encontrar com o mar, se mostra com alguns fios de água doce que rompem as espumas borbulhantes do mar, criando pequenas manchas marrons no mar azul.

Quanto ao último componente plástico, o eidético, se faz necessária a inserção de outras ilustrações com o intuito de fornecer um número maior de elementos de significação, enriquecendo a análise e a compreensão desse texto sincrético. Mas delas só iremos extrair dados que assegurem a coerência do texto verbal, no caso, da última ilustração do livro. Segundo Greimas (2002, p. 35), "o estrato eidético é considerado como o mais superficial, seguido do cromatismo e, no nível mais profundo desse gênero de percepção estética, encontra-se a luz".

\footnotetext{
${ }^{31}$ Idem, p. 28-29.
} 
Começamos pelo plano superior. Os pontilhados presentes no sol da cidade grande remetem a imagens e textos verbais que narram situações perigosas, de dúvida ou até mesmo de perdas para o garoto. São elas:

(1) quando o garoto navega próximo do canalão (ZIRALDO, 1996, p. 14-15);

(2) quando os moradores contam histórias temíveis sobre o rio (ZIRALDO, 1996, p. 18-19);

(3) quando seu amigo morre e tem o corpo localizado no fundo do rio (ZIRALDO, 1996, p. 22-23).

Pelas informações fornecidas, tanto pelo texto verbal quanto pelo visual, pode-se dizer que há uma tensão, pois o traço pontilhado e em espiral remete a um percurso passional disfórico.

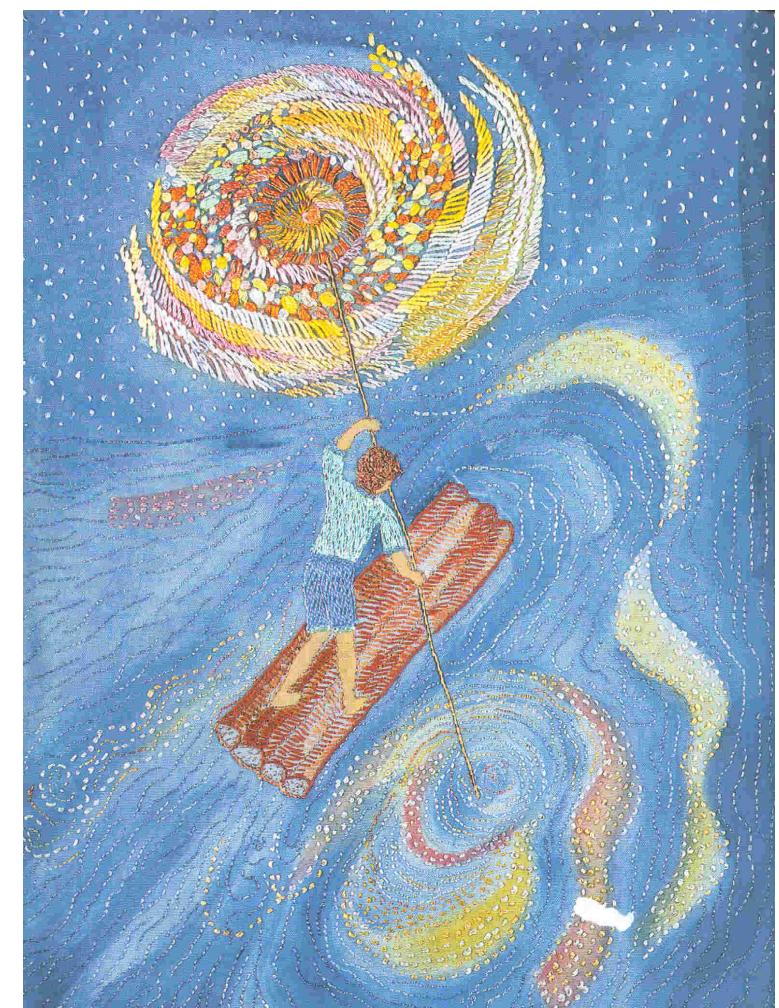

Ilustração 33. O garoto navega próximo do canalão. In: ZIRALDO. Menino do rio doce. $12^{\mathrm{a}}$ reimpressão. São Paulo: Companhia das Letrinhas, 2006, p. 14-15. 


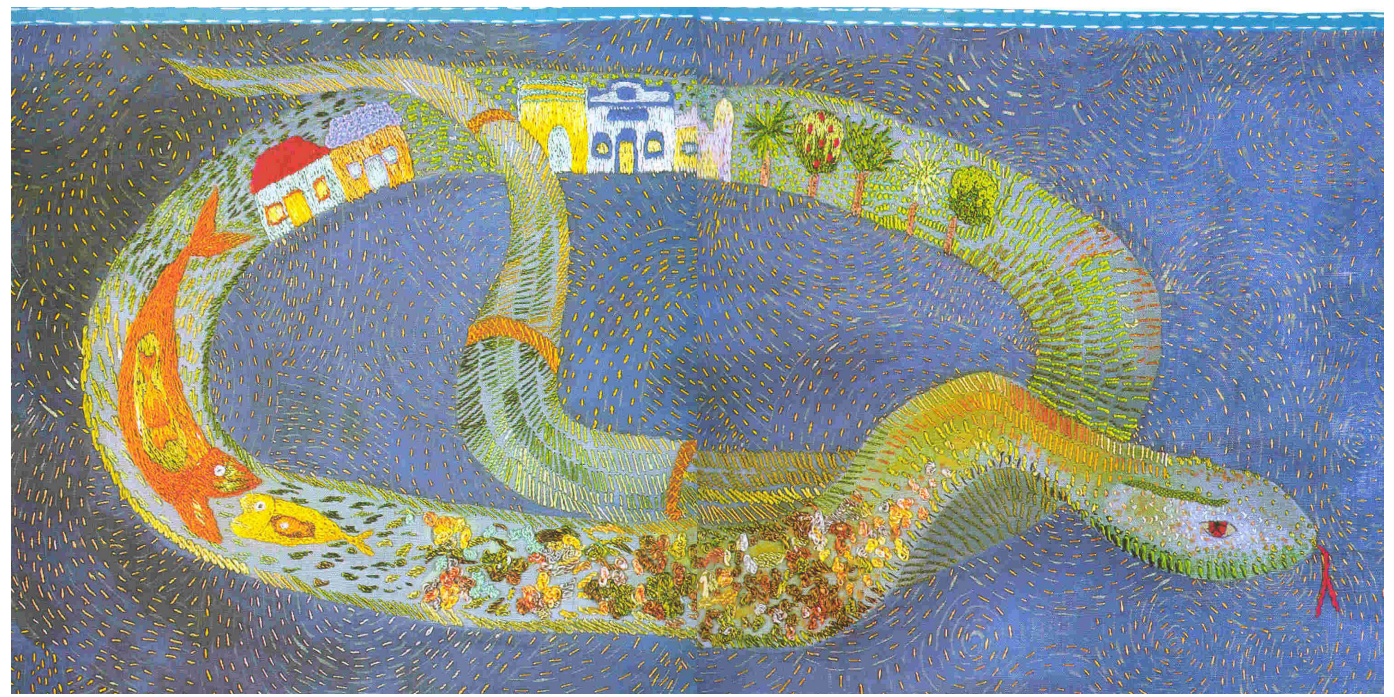

Ilustração 34. Os moradores contam histórias terríveis sobre o rio. In: ZIRALDO. Menino do rio doce. $12^{a}$ reimpressão. São Paulo: Companhia das Letrinhas, 2006, p. 18-19.

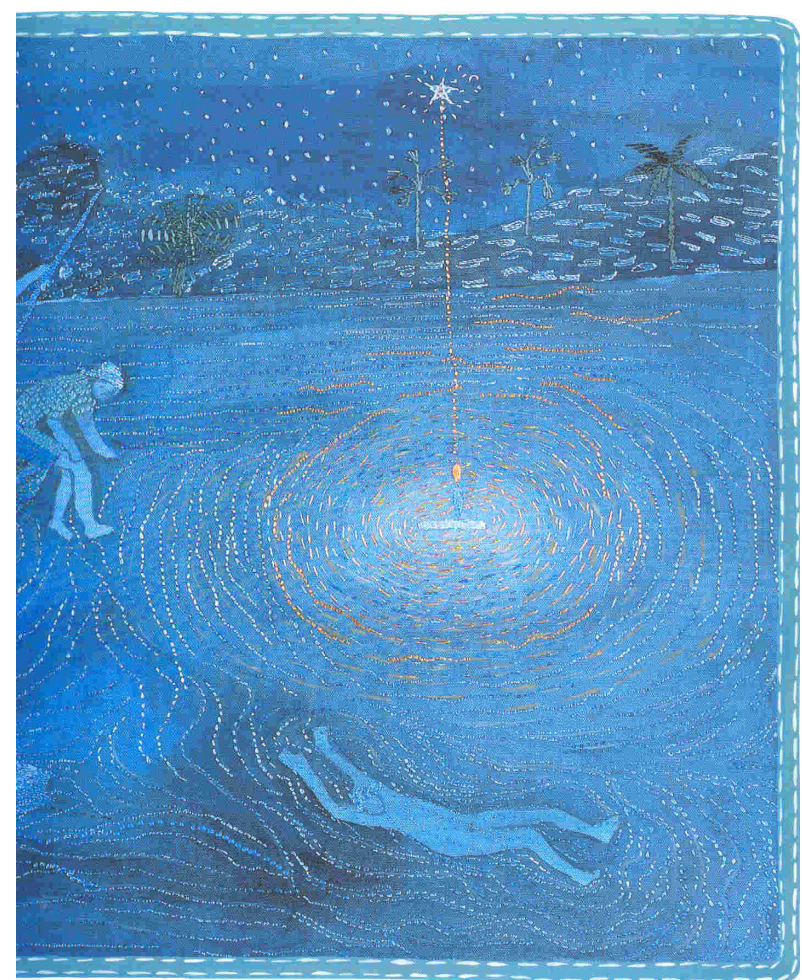

Ilustração 35. O amigo morre e tem o corpo localizado no fundo do rio. In: ZIRALDO. Menino do rio doce. $12^{\mathrm{a}}$ reimpressão. São Paulo: Companhia das Letrinhas, 2006, p. 22-23.

Todos os prédios são desenhados em linhas verticais, às vezes retas, às vezes um pouco inclinadas; enquanto as casas do vilarejo contêm linhas retas (verticais e horizontais), diagonais e circulares. 
Observa-se uma restrição e pouca mobilidade nas formas dadas à cidade grande. $O$ oposto ocorre nos desenhos das casas ribeirinhas.

Mantendo um olhar comparativo entre as duas imagens, a cidade retratada em pequenas dimensões, ocupando uma estreita faixa horizontal na parte superior da ilustração. Como já foi dito, ela não tem contato com o mar, pois os morros criam essa barreira e esse distanciamento. O vilarejo, ao contrário, ocupa todo o espaço matérico, circulando e compartilhando com o rio. Apenas uma fina linha separa o rio das casas ribeirinhas, mas o contato e a proximidade são mantidos.

Quanto ao garoto, a categoria topológica é relevante. Na primeira imagem ele aparece num tamanho proporcional aos demais elementos da ilustração, inserido na vila, pois faz parte dela. Mas, na última ilustração, o menino vê a cidade de longe, pequena, pois ela ainda não the pertence. Há o distanciamento físico e afetivo, afinal ele não a conhece.

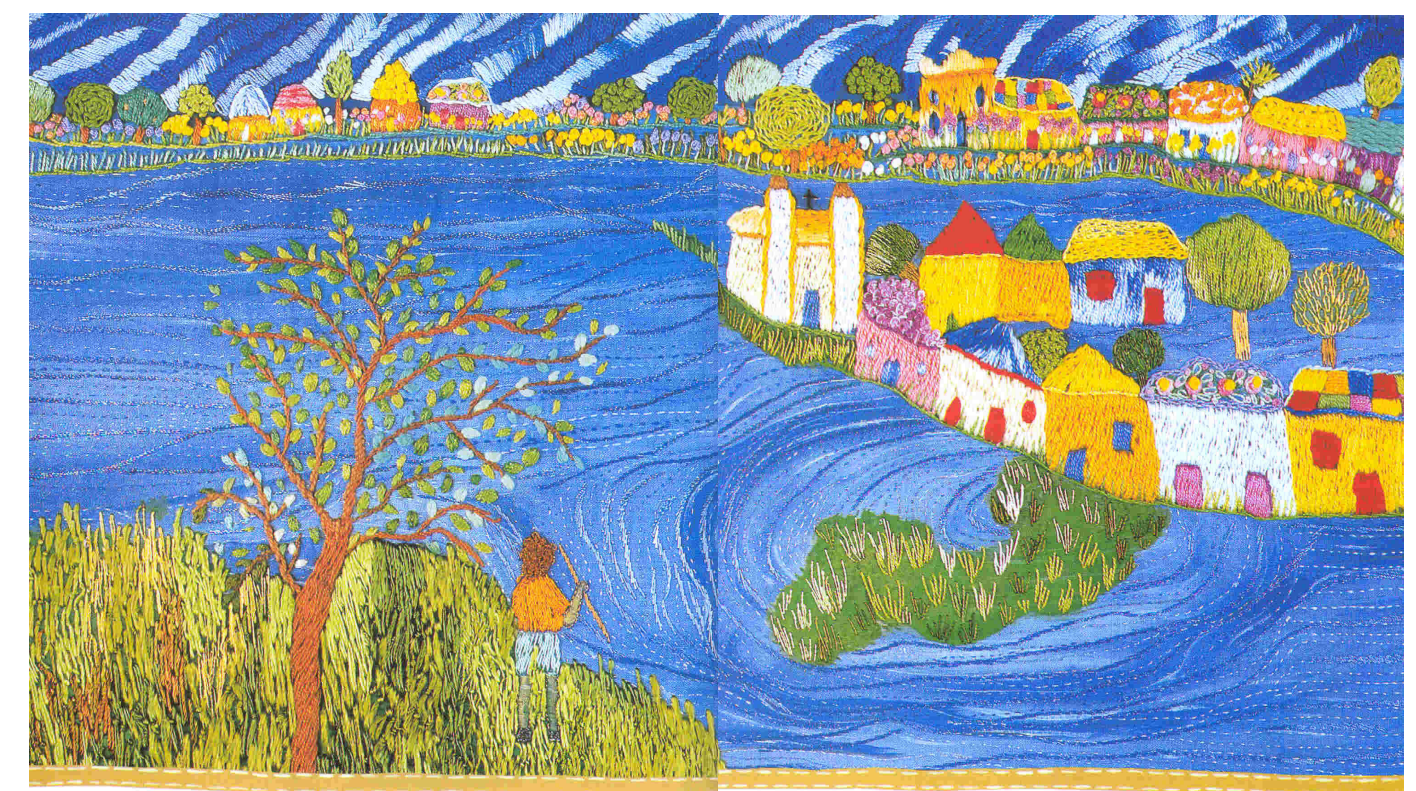

Ilustração 36. Cidade ribeirinha do garoto. In: ZIRALDO. Menino do rio doce. $12^{\mathrm{a}}$ reimpressão. São Paulo: Companhia das Letrinhas, 2006, p. 2-3.

Ao organizar esse dados, temos duas tabelas que apontam as relações entre a cidade ribeirinha e a cidade grande (natureza $x$ cultura); assim como as relações entre o rio e o mar (vida $x$ morte). Os elementos que compõem o vilarejo e o rio são, na narrativa, eufóricos para o garoto. 
Entretanto, os elementos que integram o universo da cidade grande e do mar são disfóricos.

\begin{tabular}{|c|c|c|}
\hline & Cidade ribeirinha & Cidade grande \\
\hline Cromático & $\begin{array}{c}\text { Valor: colorida } \\
\text { Tonalidade: quente } \\
\text { Pureza: mesclado } \\
\text { Luminosidade: quente } \\
\text { Céu azul mesclado (intercalando } \\
\text { tonalidade fortes e claras) }\end{array}$ & $\begin{array}{c}\text { Valor: monocromática/azul claro } \\
\text { Tonalidade: fria (acizentada) } \\
\text { Pureza: puro } \\
\text { Luminosidade: opaco } \\
\text { Céu azul claro uniforme }\end{array}$ \\
\hline Topológico & $\begin{array}{c}\text { Posição: parte inferior } \\
\text { Orientação: extensa faixa em } \\
\text { espiral } \\
\text { Dimensão: grande } \\
\text { (proporcional) }\end{array}$ & $\begin{array}{c}\text { Posição: parte superior } \\
\text { Orientação: estreita faixa } \\
\text { horizontal } \\
\text { Dimensão: pequena } \\
\text { (desproporcional) }\end{array}$ \\
\hline \multirow[t]{2}{*}{ Eidético } & $\begin{array}{l}\text { Linhas retas (verticais e } \\
\text { horizontais), diagonais e } \\
\text { circulares }\end{array}$ & $\begin{array}{c}\text { Linhas retas verticais (os prédios) } \\
\text { e pontilhadas (os morros) }\end{array}$ \\
\hline & $\begin{array}{l}\text { NATUREZA } \\
\text { (fórico) }\end{array}$ & $\begin{array}{l}\text { CULTURA } \\
\text { (disfórico) }\end{array}$ \\
\hline
\end{tabular}

Quadro 8. Os componentes plásticos da cidade ribeirinha e da cidade grande.

\begin{tabular}{|c|c|c|}
\hline & Rio & Mar \\
\hline Cromático & marrom & $\overline{\text { azul }}$ \\
\hline Topológico & $\begin{array}{c}\text { Posição: parte inferior } \\
\text { Orientação: vertical } \\
\text { Direção: ascendente }\end{array}$ & $\begin{array}{c}\text { Posição: parte superior } \\
\text { Orientação: horizontal } \\
\text { Direção: direita e esquerda }\end{array}$ \\
\hline \multirow[t]{2}{*}{ Eidético } & linhas preenchidos & linhas vazadas \\
\hline & $\begin{array}{c}\text { VIDA } \\
\text { (eufórico) }\end{array}$ & $\begin{array}{c}\text { MORTE } \\
\text { (disfórico) }\end{array}$ \\
\hline
\end{tabular}

Quadro 9. Os componentes plásticos do rio e do mar.

Os elementos eufóricos remetem às boas experiências vividas na infância pelo personagem garoto. Acrescenta-se, aí, o conhecimento que o 
menino adquire e a sua amizade com o rio. Entretanto, os elementos disfóricos estão relacionados a perdas, ao medo e ao desconhecido. Sendo assim, vida e natureza ocupam o mesmo campo afetivo eufórico, mas as categorias morte e cultura são timicamente disfóricas.

Esses elementos plásticos homologados aos planos do conteúdo do texto verbal e do pictórico, permitem-nos chegar à categoria semântica no nível fundamental: conhecido x desconhecido. Os elementos plásticos eufóricos estão relacionados ao saber/conhecer, e os disfóricos aos nãosaber/não-conhecer.

\begin{tabular}{|l|c|c|}
\hline \multicolumn{1}{|c|}{ Homologação } & Eufórico & Disfórico \\
\hline Plano da Expressão & Natureza & Cultura \\
Texto plástico: Vilarejo x Cidade grande & & \\
\hline Plano da Expressão & Vida & Morte \\
Texto plástico: Rio x Mar & & \\
\hline Plano do Conteúdo: textos verbal e visual & Conhecido & Desconhecido \\
\hline
\end{tabular}

Quadro 10. Homologação dos planos do conteúdo com o da expressão.

A narrativa mostra que o garoto reconhecia como aspectos positivos a vida na pequena cidade e a sua amizade com o rio, pois ao crescer junto deles, o menino se sentia seguro, em "casa". Os elementos disfóricos, a cidade grande e o mar, são vistos pelo garoto como algo desconhecido, porém necessário, pois são elementos figurativos da transição de garoto para homem, de imaturo para maduro.

\subsubsection{Intertextualidade e Interdiscursividade}

Antes de entrarmos na análise dos textos, apresentamos algumas definições sobre interdiscursividade e intertextualidade para melhor compreendermos seus conceitos e sua aplicação metodológica. 
No Dicionário de Semiótica (GREIMAS; COURTÉS, sd, p. 242), a definição para intertextualidade é rarefeita e pouco consistente. Ao situar o termo historicamente, os autores explicam que "o comparatismo com objetivo tipológico nos parece, no momento atual, a única metodologia capaz de empreender a realização das pesquisas intertextuais". A interdiscursividade, entretanto, está ausente neste dicionário.

Fiorin (2003, p. 30) explica que tanto a intertextualidade, quanto a interdiscursividade "dizem respeito à presença de duas vozes num mesmo segmento discursivo ou textual". Então, o que as diferencia? Segundo ele, "a intertextualidade é o processo de incorporação de um texto em outro, seja para reproduzir o sentido incorporado, seja para transformá-lo" (FIORIN, 2003, p. 30), enquanto "a interdiscursividade é o processo em que se incorporam percursos temáticos e/ou percursos figurativos, temas e/ou figuras de um discurso em outro" (FIORIN, 2003, p. 32).

A terceira, e última, definição a esses lexemas foi retirada da obra Intertextualidade e conto maravilhoso de Discini (2004), que define intertextualidade como "a retomada consciente, intencional da palavra do outro, mostrada, mas não demarcada no discurso da variante", onde "não há fronteiras, não há linha divisória entre o eu e o outro, não há ruptura" (DISCINI, 2004, p. 11). No texto "Dialogismo, Polifonia e Enunciação", Barros (2003) apresenta uma definição que se adequa bem à compreensão de interdiscursividade ao dizer que o dialogismo é polifonicamente tecido "por fios dialógicos de vozes que polemizam entre si, se completam ou respondem umas às outras" (BARROS, 2003, p. 4). O pesquisador André Valente se vale da definição de Cesare Segre para explicar que "o termo interdiscursividade designa as mais difusas conexões que todo texto, oral ou escrito, mantém com todos os enunciados (ou discursos) registrados na correspondente cultura e ordenados ideologicamente" (VALENTE, 2008, apud SEGRE, 1995, p. 186).

Diante dessas definições, identificamos no livro Menino do rio doce, diálogos - intertextuais e interdiscursivos - com algumas obras mas nos 
limitaremos, nesta pesquisa, a analisar os encontros, presentes no livro, com duas obras de Mark Twain que têm o rio Mississipi como pano de fundo das aventuras e aprendizados dos seus personagens infantojuvenis, como já fora justificado no início da análise do livro brasileiro.

Como nos lembra Fiorin a respeito do discurso manifestado em um texto: "a interdiscursividade não implica a intertextualidade, embora o contrário seja verdadeiro, pois, ao se referir a um texto, o enunciador se refere, também, ao discurso que ele manifesta" (2003, p. 35).

\subsection{Interdiscursividade}

As três obras falam do mesmo tema: a infância. O universo infantil é retratado com muitas aventuras, sofrimentos e aprendizados. Intermediando essas experiências, há um rio, sempre amigo e confidente, que acompanha o crescimento e o amadurecimento dos personagens principais: o menino sem nome de Ziraldo, Tom Sawyer e Huckleberry Finn, de Twain.

Separados pelo tempo - as obras do norte-americano foram escritas no século $\mathrm{XIX}^{32}$ - os livros abordam o cotidiano das crianças que, independentemente de época e cultura, apresentam pontos em comum, como o brincar. Entretanto, os registros e valores histórico-sociais fazem suas marcas nos textos, determinando, inclusive, o que pode ou não ser dito.

As histórias não são contadas pelas próprias crianças, pois é instaurado um interlocutor que passa a ser a voz delas. Enquanto na obra de Ziraldo a narrativa começa com uma debreagem enunciva actancial (ele), em que uma terceira pessoa relata os fatos (" $\underline{\text { menino }}^{33}$ tinha

\footnotetext{
32 Embora neste trabalho estejam sendo utilizadas edições traduzidas e recentes (2005 e 2007), os livros de Mark Twain foram publicados, pela primeira vez, em 1876 (As aventuras e Tom Sawyer) e 1884 (As aventuras de Huckleberry Finn). As obras originais, em inglês, entram nesta análise apenas com as ilustrações, no item Intertextualidade.

${ }^{33}$ Grifo nosso.
} 
certeza de que..."); nas duas obras de Twain, o texto se inicia com uma debreagem enunciativa actancial (eu): Sawyer ("a maioria das aventuras que aparecem neste livro são o reflexo da realidade; uma ou duas foram criadas por $\underline{\operatorname{mim}}^{34}{ }^{\prime . .}$ ") e Huck ("o leitor não $\underline{m e}^{35}$ conhece,..."). Na obra brasileira, o procedimento de distanciamento da enunciação cria um simulacro de verdade e de objetividade; enquanto nas obras norteamericanas, "o efeito é de subjetividade na visão dos fatos vividos e narrados por quem os viveu, que os passa, assim, impregnados de 'parcialidades'"' (BARROS, 2005, p. 57).

Os rios dessas narrativas estão situados em pequenos vilarejos, abastecendo-os com suas águas, alimentando-os com seus peixes e sendo uma fonte de renda, cumprindo sua função sócio-econômica. Mas são, também, rios figurativos que acompanham o crescimento dessas crianças, compartilham suas dores e perdas, e tornam-se - na memória de cada garoto - um amigo-irmão.

A cidade grande pertence ao imaginário da garotada, em maior ou menor intensidade tímica. Contudo, ela está lá, para além do rio e do olhar, sempre relacionada ao "ser adulto", ao "quando crescer".

$O$ universo infantil permeia essas três obras que mostram, com ironia ou com pudor, o cotidiano das crianças, desmistificando o estereótipo ${ }^{36}$ de "infância feliz", permitindo ao enunciatário fazer uma leitura crítica desse período da vida, com poesia e prosa.

\subsection{Intertextualidade}

O foco nesta análise é trabalhar a intertextualidade dentro dos textos verbais e visuais das obras, tendo como base um "processo de

\footnotetext{
34 idem.

35 idem.

36 Ruth Amossy explica que "o estereótipo permite designar os modos de raciocínio próprios a um grupo e os conteúdos globais do setor da doxa na qual ele se situa" (2005, p. 126).
} 
construção, reprodução ou transformação do sentido" (FIORIN, 2003, p. 29) de um texto em outro, podendo estabelecer uma relação contratual, ao confirmar seu sentido primeiro, ou uma polêmica, construindo um sentido oposto ao do texto incorporado.

As duas obras de Mark Twain - As aventuras de Tom Sawyer e As aventuras de Huckleberry Finn - são os textos-base da análise, que "entra como condição de construção de sentido do discurso da variante intertextual" (DISCINI, 2004, p. 11), neste caso, a obra de Ziraldo, Menino do rio doce.

Todas as variantes intertextuais assimilam o texto-base, por isso este pode ser reconhecido naquelas; elas fazem isso ao confirmar o texto-base ou ao confrontar-se com ele. Se o confirmam, apresentam, com o texto-base, uma relação de implicação, de complementariedade. Se se confrontam com ele, apresentam uma relação de oposição: de contrariedade ou de contraditoriedade (DISCINI, 2004, p. 16).

Mas, sendo esses textos poéticos, os mesmos

se caracterizam pela ambivalência intertextual interna que, graças à multiplicidade de vozes e de leituras, substitui a verdade 'universal', única e peremptória, pelo diálogo de 'verdades' textuais (contextuais) e históricas (BARROS, 2003, p. 7).

Vamos, então, aos encontros nos textos verbais, sejam polêmicos ou não. Embora, em grande parte, haja uma polêmica velada, disfarçada em "o não-dito" ou "politicamente correto", em que a variante intertextual subtrai temas polêmicos como: preconceito, violência, sexualidade e racismo, fortemente marcados e descritos nos textos-base.

O brincar dessas crianças é descrito de forma muito parecida: nadar no rio; brincar de pirata com os amigos; navegar nas jangadas; pescar; enfrentar os desafios naturais que o rio impõe, como os canais/canalões; e compartilhar suas angústias na beira do rio, pois só este os ouve e os entende. Até mesmo a tragédia de morrer afogado é vista por eles como fato natural da vida, como fato aceito com resignação, pois, como diz a tia 
de Tom, Sr. Polly, "Deus o deu, Deus o levou" (TWAIN, 2007, p. 100), e o menino, "pois que o rio, às vezes, faz sua misteriosa vontade" (TWAIN, p. 15).

Mas assim como o rio se parte em dois, ou mais, e segue o seu destino, as obras desses dois autores também se separam seguindo, cada um, seu estilo e sua história. Enquanto crescer, para o menino de Ziraldo, é descrito de forma sentimental, uma vez que seu rio poeticamente the fornece o saber e a vivência; os meninos de Twain, nas duas obras, enfrentam uma realidade dura e cruel em que "a vida parecia-Ihe sem sentido e a existência nada mais do que um fardo" (2007, p. 22). Nesta obra, os fatos são apresentados sem rima, sem leveza ou candura. Dessa forma, podemos dizer que o primeiro autor apresenta a infância de forma fórica, já o segundo, ao contrário, a descreve disforizada.

[...] nenhum elemento do conteúdo escapa à relação polêmica. Cada tema e/ou figura de um discurso nega tema e/ou figura correspondente de seu outro.[...] As mesmas palavras podem estar presentes nos dois, mas, com as mesmas palavras, eles não falam das mesmas coisas (FIORIN, 2003, p. 33).

Quanto às crianças, o menino de Ziraldo tem um éthos ${ }^{37}$ comedido, da justa-medida, não manifestando contrariação ou indignação com os fatos transcorridos. Os garotos de Twain apresentam um éthos astucioso, hiperbólico, manifestando pontos de vista e tendo um olhar crítico sobre pessoas e acontecimentos.

As descobertas de cada garoto também apresentam olhares distintos. Por meio do processo de relação por alusão, em que "não se citam as palavras (todas ou quase todas), mas reproduzem-se construções sintáticas em que certas figuras são substituídas por outras" (FIORIN, 2003, p. 31), temos um texto polarizado: enquanto um reflete de forma prática e astuta sobre os fatos cotidianos, o outro se deixa levar

\footnotetext{
37 Segundo Ruth Amossy, "a construção discursiva, o imaginário social e a autoridade institucional contribuem, portanto, para estabelecer o éthos e a troca verbal do qual ele é parte integrante" (2005, p. 137).
} 
pelos pensamentos intimistas. O personagem Tom, por exemplo, após observar certos acontecimentos, "descobrira, sem o saber ${ }^{38}$, uma grande lei que rege a humanidade e que é: para se conseguir que um homem ou um menino cobice uma coisa, basta tornar essa coisa difícil de obter" (TWAIN, 2007, p. 26). O menino do rio doce tem pensamentos mais filosóficos: "o menino se indagava (sem saber que se indagava) ${ }^{39}$ : o que há além do rio" (p. 10).

A infância do personagem de Ziraldo é mostrada de forma terna e saudosista, com uma linguagem e comportamento éticos e politicamente corretos - valores da sociedade atual - sem entrar em confrontos e/ou conflitos, embora a narrativa não negue as perdas e sofrimentos. Ela simplesmente não as polemiza. Em Twain, há um humor irônico, muitas vezes escrachado, em que o politicamente correto passa a passos largos, provocando gargalhadas e indignação. São diferenças de estilo e de épocas que servem como marcadores sociais.

Sem rastro de ironia ou paródia, o garoto de Ziraldo segue um percurso linear, sem grandes surpresas ou sustos, sem críticas sociais. Os garotos de Twain, pelo contrário, apresentam um humor ácido e mordaz:

(1) "Sabia sem titubear que seis vezes sete são trinta e cinco" (TWAIN, 2005, p. 25).

(2) "Tentaram também a medicina, o hipnotismo, o missionarismo, enfim, um pouco de todas as artes para iludir o próximo" (TWAIN, 2005, p. 209).

(3) "[...] e um menino, descendente de alemães, ganhara quatro ou cinco (bíblias). Um vez recitara sem parar três mil versículos, mas o esforço de memória foi tão grande que desde então ficou quase idiota" (TWAIN, 2007, p. 35).

(4) "Pouco a pouco a multidão encheu os bancos (tribunal). Veio [...] o corregedor e a mulher, porque, entre outras coisas desnecessárias, havia na vila um corregedor" (TWAIN, 2007, p. 41).

(5) "Huckleberry era cordialmente detestado e temido por todas as mães da aldeia, porque era preguiçoso, desobediente, ordinário e mau, mas principalmente porque todos os meninos o admiravam, se deliciavam na sua companhia e não tinham coragem de serem exatamente

\footnotetext{
38 Grifo nosso.
}

39 Idem. 
como ele" (TWAIN, 2007, p. 48-49).

(6) "Era uma alma simples e honesta, e por isso mesmo uma vítima fácil" (TWAIN, 2007, p. 82).

Saber escutar o rio, por exemplo, parece ter sido mérito somente do menino do rio doce. Conhecendo seus segredos e construindo uma relação de cumplicidade, ele logo aprendeu que o que diziam sobre o rio não passava de crendices: "É por isso que o menino não temia a serpente que - contavam - morava lá sob as águas do rio..." (ZIRALDO, 2006, p. 19). Tom, ao contrário, ratifica e expande esse saber folclórico: "...foi andando e atravessou duas ou três vezes um pequeno braço de rio, pois tinha a superstição de que passar por cima da água frustrava a perseguição" (TWAIN, 2005, p. 61). Às vezes suas crenças beiravam o estapafúrdio:

\footnotetext{
"Joe e Huck voltaram então para a água, mas Tom não; é que ao tirar as calças, deixara cair da perna o seu cordão com anéis de cascavel, e não sabia mesmo como passara sem cãibras durante tanto tempo, não levando consigo aquele valioso talismã" (TWAIN, 2007, p. 104).
}

Esses diálogos entre as obras brasileira e norte-americana só se tornam possíveis ao enunciatário se o mesmo tiver um repertório, um saber que faça as interligações com outro texto. Ao encontrar no livro de Ziraldo a citação aos personagens Tom e Huck, o leitor abre uma outra porta de leitura e compreensão, caso contrário, a leitura se limita. "Uma leitura intertextual só se concretiza quando o leitor tem o repertório necessário para fazê-la e a enunciação com característica fundamentalmente intertextual" (FRANCO, 2004, p. 218).

Embora relatem suas histórias com conteúdos polêmicos, os personagens dos livros se unem para falar do amor pelo rio. O rio que construiu suas histórias, que deixou registros marcantes em suas memórias e, quando adultos, compartilharam, com romantismo ou ironia, o que seus sentidos e seus afetos guardaram. Estamos falando também de uma memória afetiva que une essas vozes. 
Diante desses diálogos e vozes encontrados nos textos verbais, acrescentamos, agora, na análise intertextual, os textos visuais. Ziraldo foi beber na fonte do Mississipi, ao inserir, por citação, as mesmas características físicas do personagem Tom Sawyer em seu menino do rio doce. Na obra de Twain, o garoto é descrito assim: "Tinha o cabelo molhado e cuidadosamente escovado, todo em caracóis" (p. 34). Completando as informações, a ilustração do frontispício do livro The Adventures of Tom Sawyer, de 1876, mostra-o com os cabelos cacheados e claros. Esses dados foram relevantes na construção imagética do menino de Ziraldo, que mostra grande semelhança com o personagem de Twain. Vejamos abaixo:

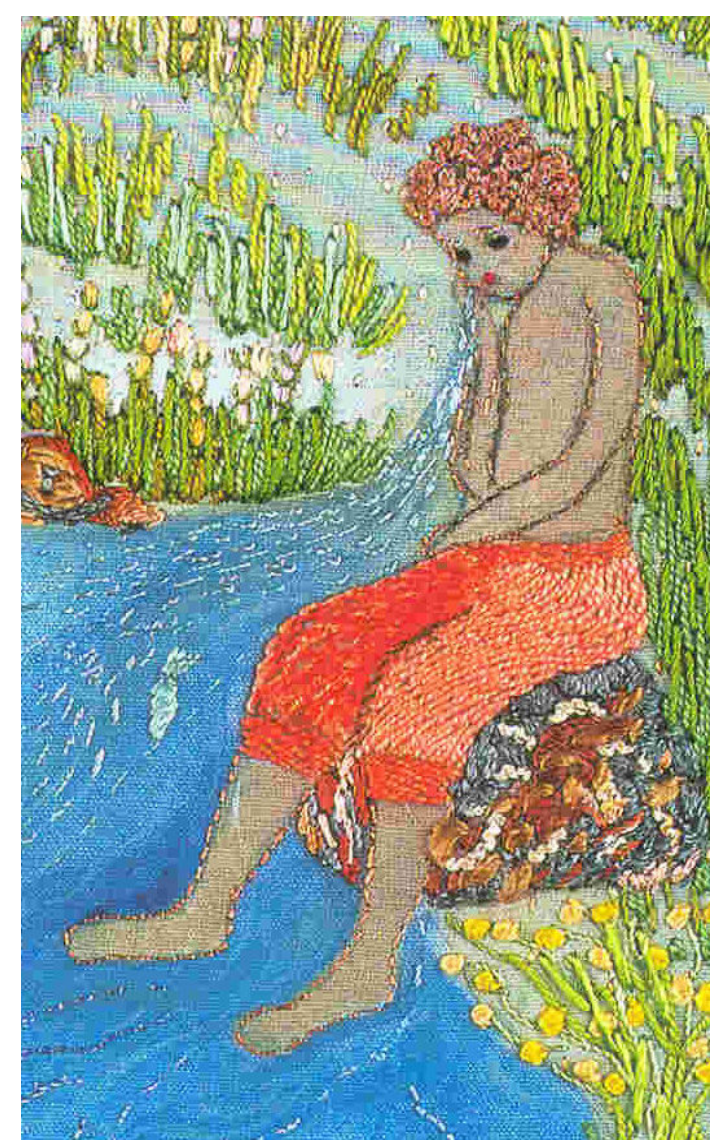

Ilustração 37. Características físicas do garoto. ZIRALDO. Menino do rio doce. $12^{a}$ reimpressão. São Paulo: Companhia das Letrinhas, 2006, p. 25.

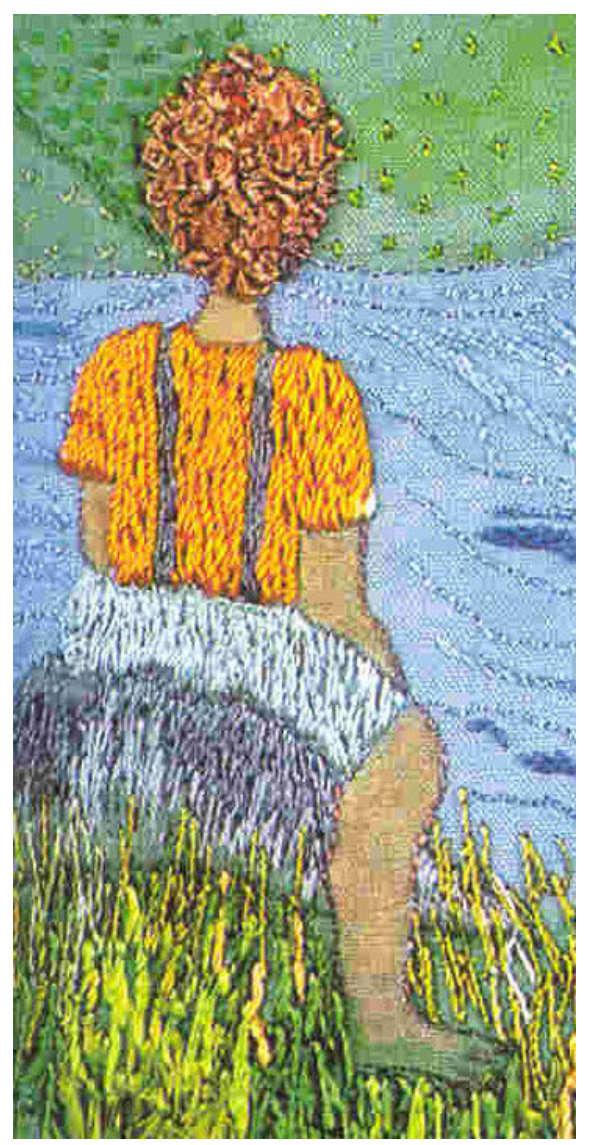

Ilustração 38. Características físicas do garoto. ZIRALDO. Menino do rio doce. $12^{a}$ reimpressão. São Paulo: Companhia das Letrinhas, 2006, p.11. 


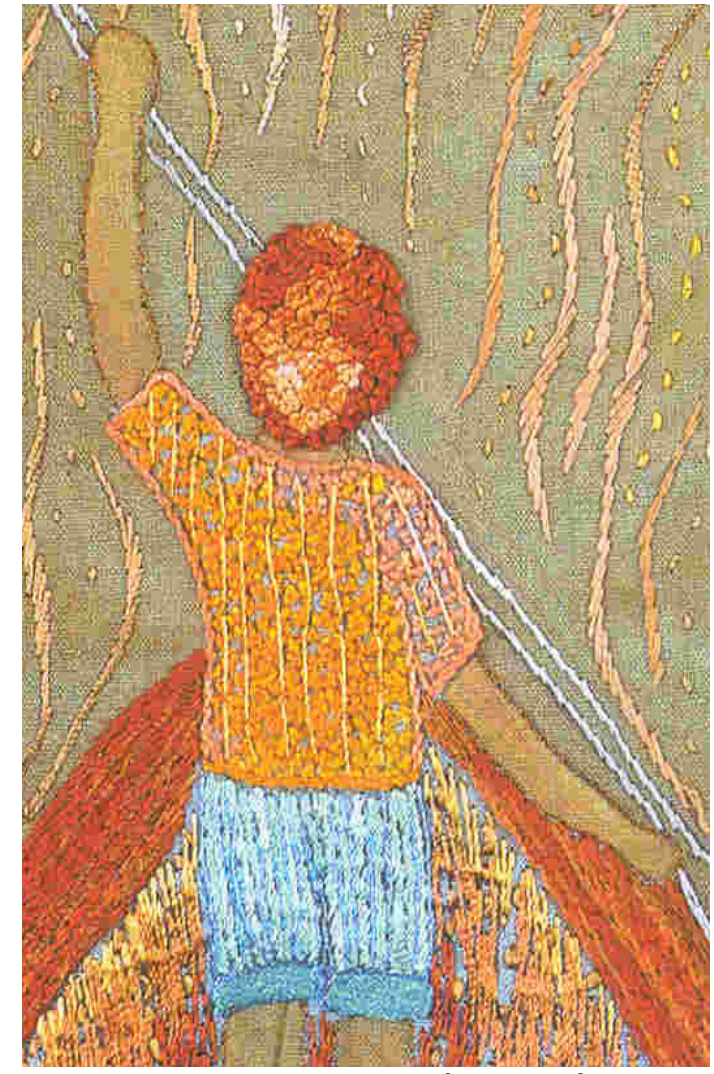

Ilustração 39. Características físicas do garoto. ZIRALDO. Menino do rio doce. $12^{a}$ reimpressão. São Paulo: Companhia das Letrinhas, 2006, p. 28.

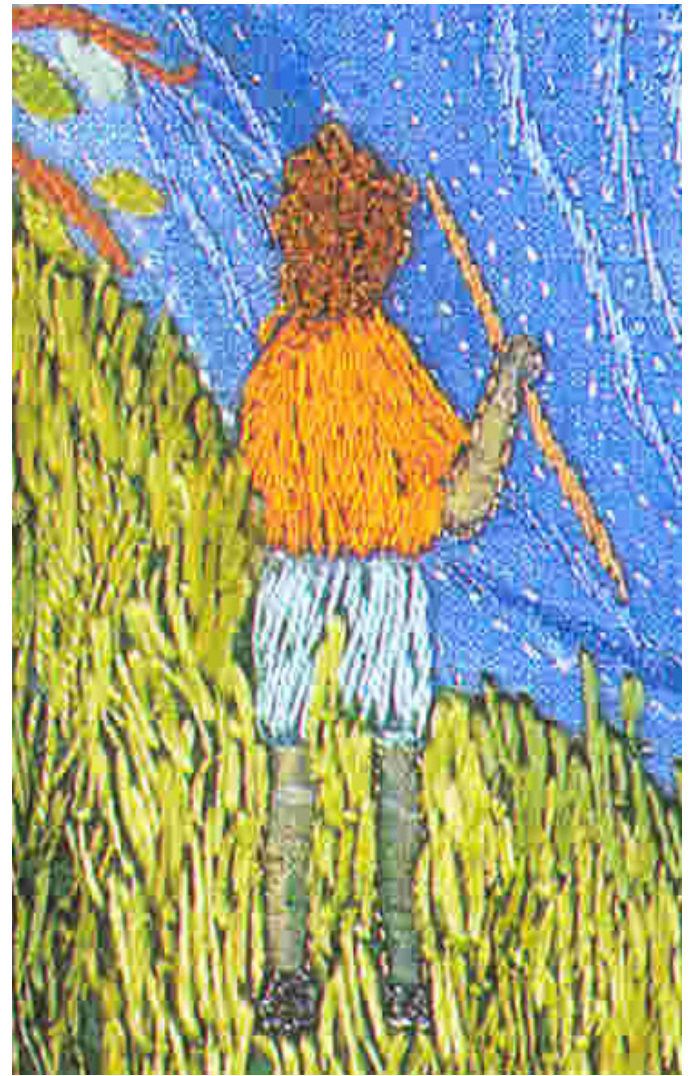

Ilustração 40. Características físicas do garoto. ZIRALDO. Menino do rio doce. $12^{a}$ reimpressão. São Paulo: Companhia das Letrinhas, 2006, p. 2.

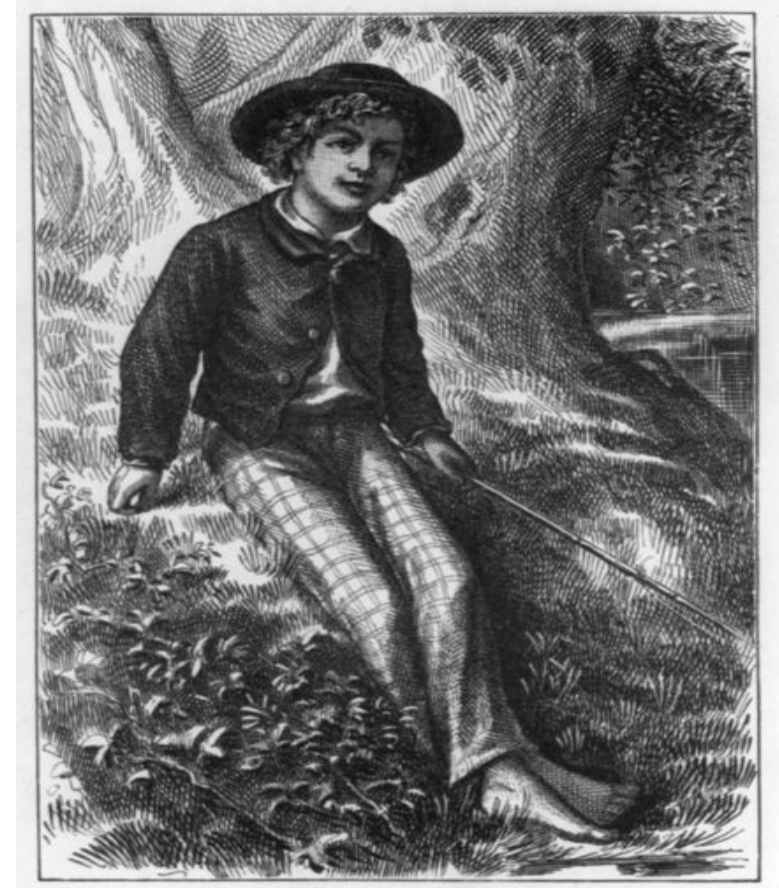

Ilustração 41. Características físicas de Tom. Frontispício do livro The Adventures of Tom Sawyer, de Mark Twain (1876). 
Outra imagem encontrada nos textos é a da jangada. Embora existam vários modelos de jangadas, nos três textos elas aparecem iguais, sempre sendo usadas por crianças, seja para brincar ou para atravessar de um lado para outro do rio.

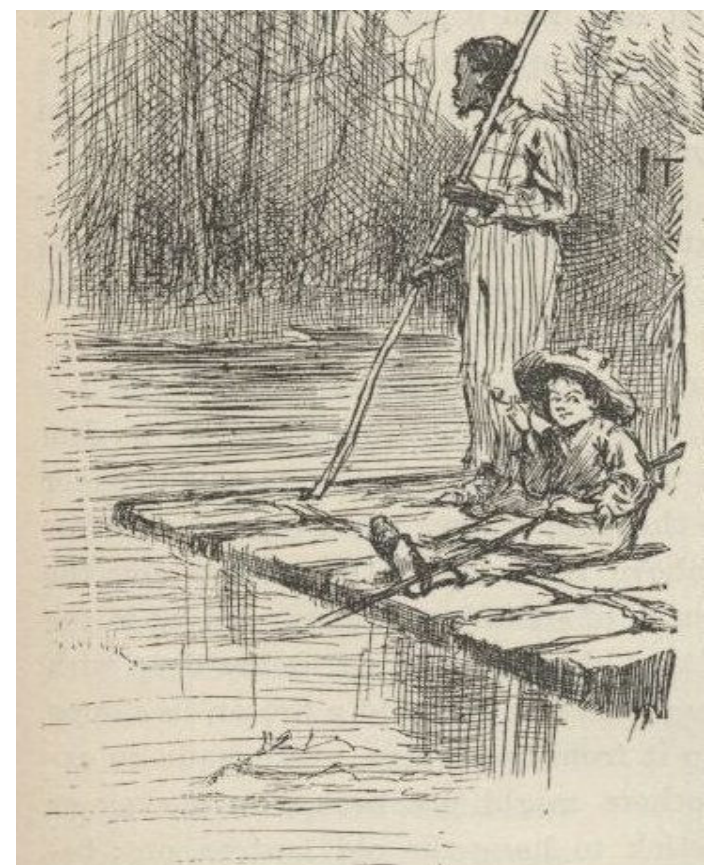

Ilustração 42. Huck na jangada. TWAIN, Mark. The adventures Huckleberry Finn (1884)

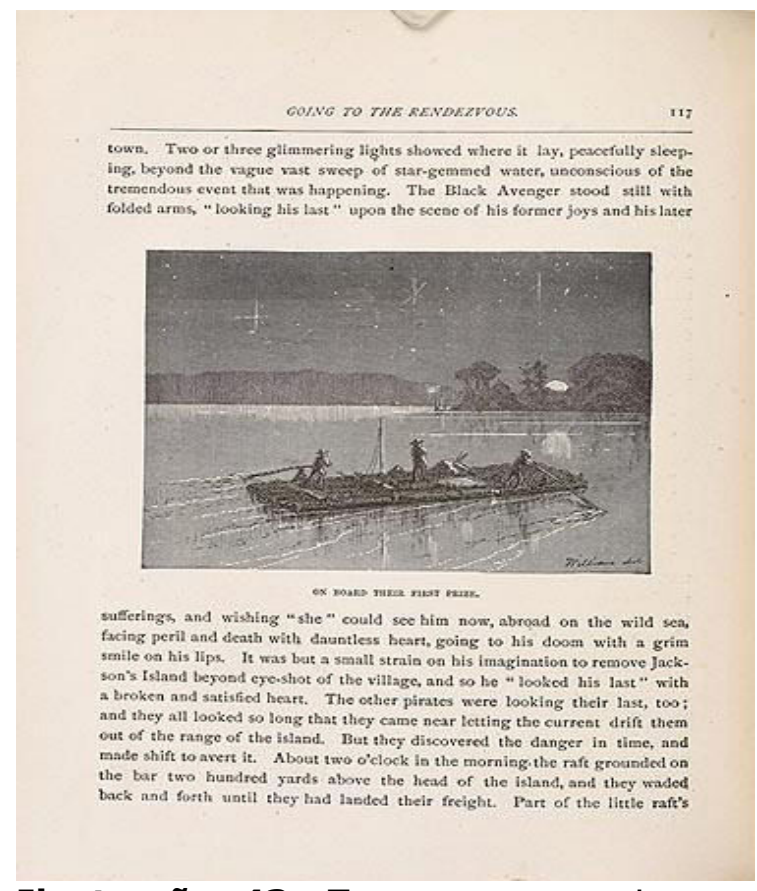

In: Ilustração 43. Tom e seus amigos na of jangada. In: TWAIN, Mark. The adventures of Tom Sawyer (1876)

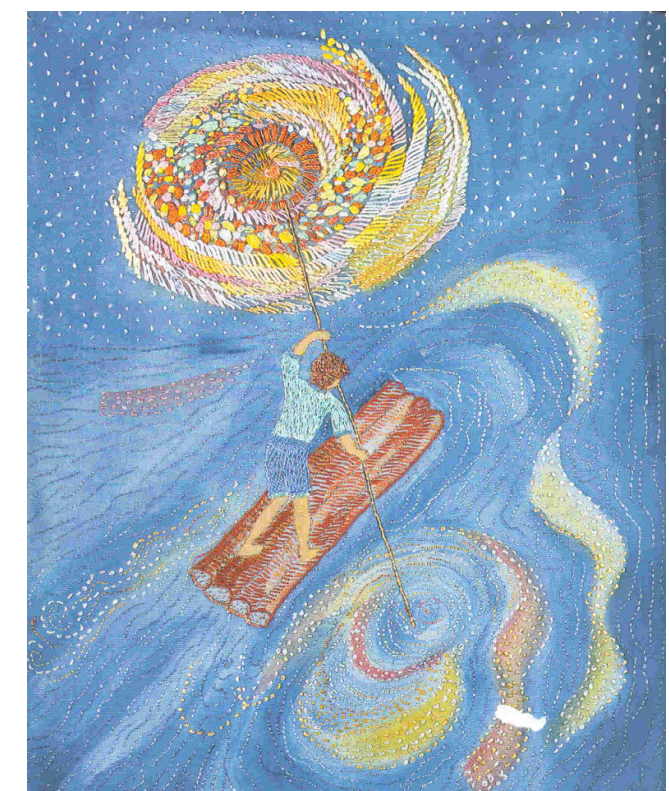

Ilustração 44. O menino na jangada. In: ZIRALDO. Menino do rio doce. $12^{a}$ reimpressão. São Paulo: Companhia das Letrinhas, 2006, p. 14. 
Mais adiante, sem escrever uma única linha sobre o barco a vapor, tem-se a ilustração dessa embarcação (Cf. p. 27 do conto brasileiro). Este transporte, tão presente e importante nos romances do escritor norteamericano, aparece ao final da história de Ziraldo, quando o menino, ao tornar-se um rapaz, deixa sua pequena cidade. Nas histórias, essa embarcação aparece sempre para viagens longas e em grandes eventos.

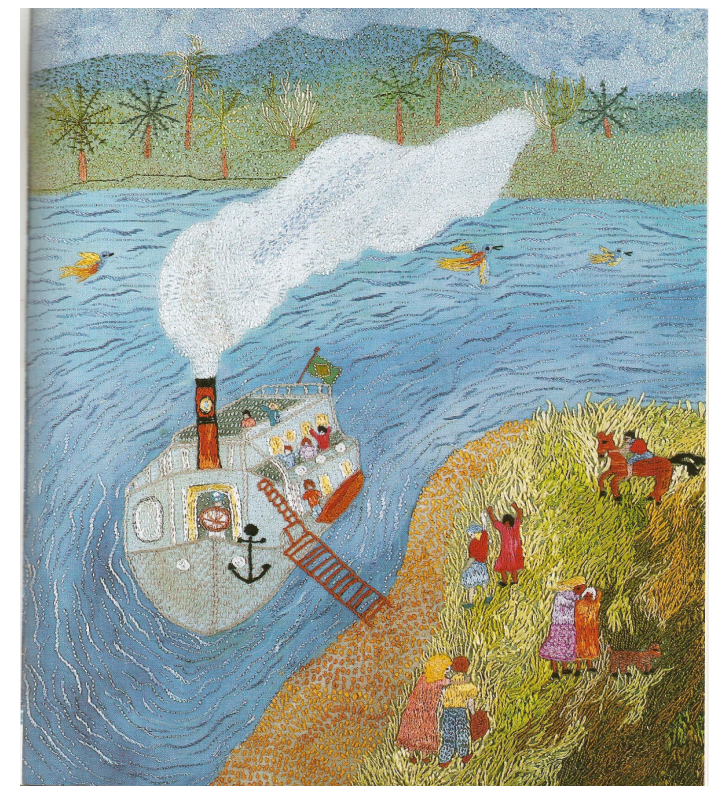

Ilustração 45. O menino partindo em um barco a vapor. ZIRALDO. Menino do rio doce. $12^{\mathrm{a}}$ reimpressão. São Paulo: Companhia das Letrinhas, 2006, p. 27.

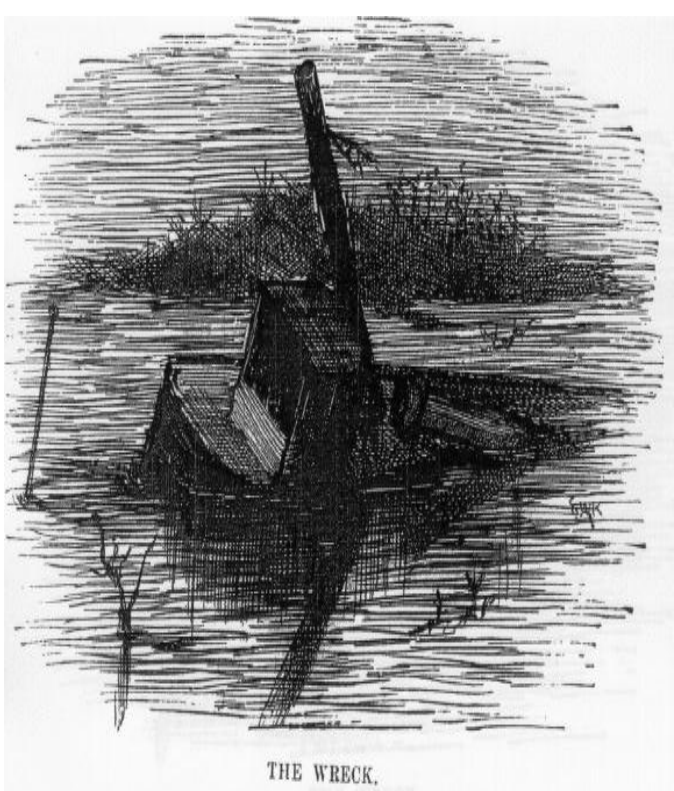

Ilustração 46. Barco a vapor afundando. TWAIN, Mark. The adventures of Huckleberry Finn.

Vemos que "o texto é [...] um 'tecido' organizado e estruturado como objeto de comunicação, ou melhor, como objeto de uma cultura, cujo sentido depende, em suma, do contexto sócio-histórico". (BARROS, 2003 , p. 1). Observa-se que vários elementos dos romances de Twain foram incorporados, reproduzidos e/ou transformados no conto de Ziraldo. Apenas ao citar o nome dos garotos de Twain, abriu-se um leque de leituras, enriquecendo o próprio texto de Ziraldo. Essas vozes que se instalam no texto mostram que "sob um texto ou um discurso, ressoa outro texto ou outro discurso; sob a voz de um enunciador, a de outro" (FIORIN, 2003, p. 34). 


\subsection{Semiótica plástica}

\subsubsection{O Barroco e o Clássico nas capas de livros infantis ilustradas pelo grupo Matizes}

"...Em vez de peraltagem eu fazia solidão. Brincava de fingir que pedra era lagarto. Que lata era navio...De uma infância livre e sem comparamentos. Eu tinha mais comunhão com as coisas do que comparação. Porque se a gente fala a partir de ser criança, a gente faz comunhão: de um orvalho e sua aranha, de uma tarde e suas garças, de um pássaro e sua árvore."

Manoel de Barros ${ }^{40}$

A última parte deste trabalho trata das questões da plasticidade em objetos imagéticos, tendo como recorte as capas de dois livros do corpus. Desse modo, os livros que tiveram as capas analisadas, foram: $A$ Bola e $o$ Goleiro, de Jorge Amado, em sua 14 edição, publicado em 2007 pela editora Record; e A Menina, a Gaiola e a Bicicleta e Céu de Passarinhos, de Rubem Alves e Carlos Brandão, em sua $5^{a}$ reimpressão, publicado em 2004 pela editora Companhia das Letrinhas.

A motivação para tal trabalho se deve à evidente diferença plástica e, por consequência, estética, das ilustrações que compõem as obras. 0 livro da Companhia das Letrinhas, por exemplo, teve o trabalho gráfico, isto é, plástico, reconhecido ao ganhar o prêmio Jabuti, concedido pela Câmara Brasileira do Livro (CBL), de "melhor Ilustração Infanto-Juvenil", em 1998. No ano anterior, o mesmo livro também foi reconhecido pela crítica especializada, ao receber o selo de "Altamente Recomendável", pela Fundação Nacional do Livro Infantil e Juvenil (FNLIJ).

\footnotetext{
${ }^{40}$ BARROS, Manoel de. Memórias inventadas: a infância. $2^{\mathrm{a}}$ reimpressão. São Paulo: Planeta, 2007, p. 5.
} 
A obra A Menina, a Gaiola e a Bicicleta e Céu de Passarinhos apresenta, sem dúvida, qualidades poéticas ao criar o novo, fugindo do estereótipo e refazendo uma leitura de mundo. Estamos diante, então, de um objeto semi-simbólico que cria novos sentidos ao estabelecer relações entre as categorias dos planos da expressão e do conteúdo.

A linguagem plástica se caracteriza, essencialmente, pela relação poética que vincula sua forma de expressão à sua forma de conteúdo. A plasticidade seria, assim, essa propriedade da linguagem de, concentrando-se sobre a dimensão figurativa do discurso, criar efeitos de sentido plásticos a partir do espessamento da materialidade discursiva, de modo a construir correspondência entre os planos da expressão e do conteúdo (TEIXEIRA, 2004, p. 241-242).

Embora as duas capas sejam fotografias de bordados feitos pelo grupo Matizes, o resultado é destoante, levantando as seguintes questões: (i) o que gerou essa distinção?; (ii) que elementos de significação - a técnica do bordado, o projeto gráfico, a impressão foram pertinentes para esse resultado?; (iii) sendo a capa de um livro a porta de entrada para a leitura da obra, quais os procedimentos adotados para ocorrer a apreensão estética pelo sujeito-observador ou o leitor/enunciatário? Para responder a essas questões, buscaremos localizar as ocorrências e as relações nas duas capas, ou melhor, nos dois textos visuais.

A imagem, por exemplo, não será, para o semioticista, o mesmo tipo de signo icônico ou de mensagem constituída de signos icônicos; ao contrário, ela será abordada como um texto-ocorrência, ou seja, como o resultado de um processo complexo de produção de sentido, cujas etapas, essencialmente, não são diferentes dos processos gerados de qualquer outro texto, seja linguístico ou não ( $F L O C H$, 1985, p. 12).

Sabe-se que a capa de um livro tem a missão de criar um envolvimento físico do leitor com o livro, de desencadear uma experiência 
estésica, mostrando que aquele objeto-livro deve ser apanhado, tocado, visto e lido. Que estratégias, então, são adotadas para que haja esse encontro e ele seja bem sucedido? A fim de depreender tais estratégias, identificaremos os elementos matéricos que compõem essas imagens e constroem a significação, além de percebermos como esses elementos atuam para que ocorra, como já dissemos, a apreensão estética do sujeito-observador.

Para Floch, a semiótica plástica busca "compreender as condições, assim como a intencionalidade de um certo modelo de relação entre um significante (visual) e um significado" (1985, p. 13). Nesse momento, entram os elementos figurativos que oferecem, através das formas, das cores e do espaço, elementos de produção de sentido. Assim sendo, a semiótica plástica baseia-se, então, "sob a conformidade de categorias de expressão e de categorias do conteúdo" e seu reconhecimento "implica a concepção simbólica de sistemas semi-simbólicos" (FLOCH, 1985, p. 75).

Embora, seja importante acrescentar que o semi-simbolismo pode

ser diferente conforme as categorias da expressão com
substâncias de ordens sensoriais diversas, se
correlacionando com uma única categoria do conteúdo[...]
ou ao homologar cada uma das relações da expressão a uma
categoria do conteúdo. [...] O sincretismo somente ocorre
quando diferentes substâncias da expressão (sonora,
olfativa, visual) se articulam em uma única forma (BARROS,
2005b, p. 152).

Diante de um objeto plástico, pode-se trabalhar de forma isolada ou conjunta com os planos do conteúdo e da expressão. Para o propósito desse trabalho, a análise dará prioridade ao plano da expressão que representa o sensorial do plano do conteúdo, isto é, a substância de ordem sensorial composta pelos elementos visual, sonoro, olfativo e tátil. No caso das ilustrações, ganham relevância os elementos visuais e táteis, pois geram sensações e criam significações.

Abaixo, podemos observar as capas dos livros que serão analisadas: 


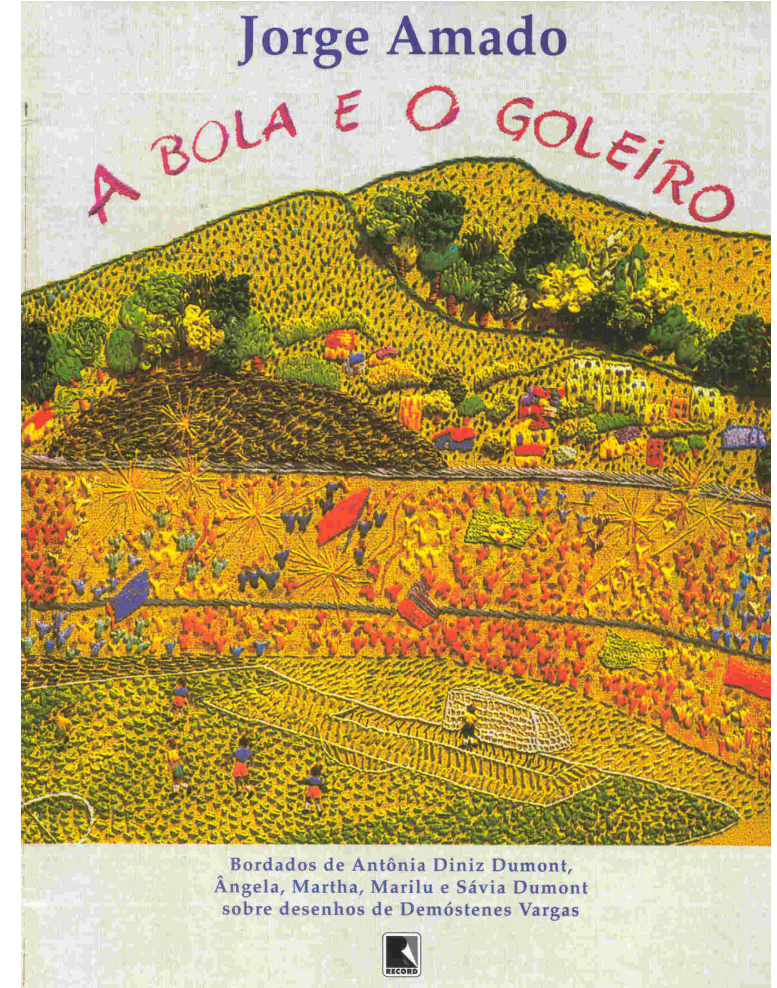

Ilustração 47. Capa do livro. AMADO, Jorge. A bola e o goleiro. $14^{a}$ ed. Rio de Janeiro: Record, 2007.

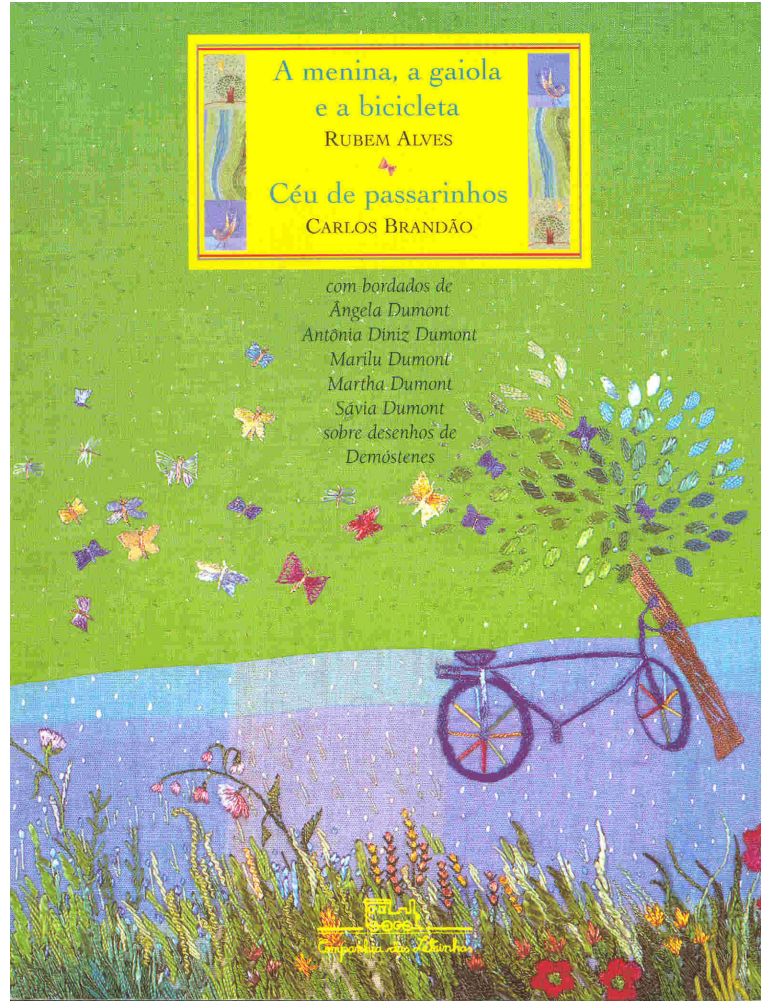

Ilustração 48. Capa do livro. ALVES, Rubem; BRANDÃO, Carlos. A menina, a gaiola e a bicicleta/Céu de

passarinhos. São Paulo: Companhia das Letrinhas, 2004.

As propostas de Floch são o ponto de partida para a análise. Para trabalhar com elementos plásticos, o semioticista montou uma grade com categorias que identificam e caracterizam as obras por meio de seus traços, formas e cores, resultando, assim, em cinco itens que separaram dois estilos de arte: o barroco e o clássico. Essas categorias

se referem ao papel acordado com a linha, o tratamento da "terceira dimensão", a atenção concedida ao formato ou aos limites da obra, a autonomia mais ou menos acordada às partes em relação ao todo e, finalmente, a claridade da luz e sua relação com a forma (FLOCH, 1993, p. 82).

A elaboração dessa grade semiotizada tem como base teórica as leituras do historiador de artes $\mathrm{H}$. Wölfflin, que faz uma separação categórica para os estilos de arte barroca e clássica. O quadro proposto por Floch mostra essas oposições, que servem com orientação para a 
análise de objetos plásticos, como fotografias, ilustrações, desenhos, bordados, quadros etc.

\begin{tabular}{|c|c|}
\hline VISÃO CLÁSSICA & VISÃO BARROCA \\
\hline $\begin{array}{l}\text { LINEAR } \\
\text { Linha-contorno é significante }\end{array}$ & $\begin{array}{c}\text { PICTÓRICA } \\
\text { A linha é um simples elemento de } \\
\text { sombreado }\end{array}$ \\
\hline $\begin{array}{c}\text { PLANO } \\
\text { Divisão do espaço em zonas paralelas }\end{array}$ & $\begin{array}{c}\text { PROFUNDIDADE } \\
\text { O movimento capta todas as coisas } \\
\text { em profundidade }\end{array}$ \\
\hline $\begin{array}{c}\text { FORMA FECHADA } \\
\text { A organização plástica leva em conta } \\
\text { as qualidades do formato }\end{array}$ & $\begin{array}{c}\text { FORMA ABERTA } \\
\text { A forma (formato) parece fortuita } \\
\text { (imprevista, não planejada) }\end{array}$ \\
\hline $\begin{array}{l}\text { MULTIPLICIDADE } \\
\text { Uma relativa autonomia é concedida } \\
\text { às distintas partes }\end{array}$ & $\begin{array}{c}\text { UNIDADE } \\
\text { As partes perdem o direito a uma } \\
\text { existência autônoma }\end{array}$ \\
\hline $\begin{array}{c}\text { CLARIDADE } \\
\text { A forma se desvela em sua totalidade }\end{array}$ & $\begin{array}{c}\text { OBSCURIDADE } \\
\text { A forma não corresponde à forma do } \\
\text { objeto }\end{array}$ \\
\hline
\end{tabular}

Quadro 11. (Cf. FLOCH, 1993, p. 89).

Possivelmente, não encontraremos todas as características de um estilo em um único texto plástico, mas alguns traços que nos permitam fazer uma leitura de qual estilo o texto está mais próximo ou não e, dessa forma, teremos informações pertinentes para extrair os efeitos de sentido produzidos. Greimas explica que esses "feixes de traços visuais, de densidade variável", tornam-se os "formantes figurativos", dotados "de significados, transformando, assim, as figuras visuais em signos-objetos" (GREIMAS, 2004, p. 80).

O objetivo não é somente classificar as obras, etiquetando-as, mas, através desses dados, cruzar com outras leituras e estabelecer novas relações que ampliem a compreensão do texto visual. Os estilos barroco e clássico nos servem para extrair os elementos mais significativos e trazer 
ao debate as questões pertinentes ao universo plástico, como a textura e a luz. As propostas da semioticista Anne Beyaert-Gislen, que analisa objetos plásticos, nos enriquecem e têm contribuído, por meio de suas reflexões, para uma metodologia de análise dos textos.

Sendo cada cultura dotada de uma "visão de mundo" que lhe é própria, ela impõe por isso mesmo condições variáveis ao reconhecimento dos objetos e, consequentemente, à identificação das figuras visuais como algo que "representa" os objetos do mundo, contentando-se frequentemente com esquematismos vagos, mas exigindo, por vezes, reprodução minuciosa dos detalhes "verídicos". (GREIMAS, 2004, p. 80).

\subsubsection{O plano da expressão na obra de Rubem Alves e Carlos Brandão}

Iniciamos as análises com a capa do livro de Rubem Alves e Carlos Brandão. A ilustração é limpa e clara, com traços delicados e formas nítidas. Essas formas são autônomas, se articulam com independência e liberdade. A claridade, segundo Floch, sugere uma extensão.

Essa extensão se considerará a continuação, uma
manifestação peculiar, espacial, de um processo de
implantação mais abstrato: claro pode significar sereno,
tranquilo. [...] A claridade sugere o contorno, a delimitação
e, sobretudo, é, em primeiro lugar, uma implantação, uma
articulação ou um espaçamento medido. O claro se opõe
tanto ao lamacento como ao vaporoso, qualidades
visivelmente fabricadas, se assim podemos dizer, a base da
não-descontinuidade, de passagens, de efeitos de limite
(FLOCH, 1993, p. 70-71).

Esse efeito de sentido de serenidade que a claridade constrói, é firmada com outras relações cromáticas. As cores são separadas topograficamente em três partes: a) no topo, uma inserção amarela; b) no fundo e ocupando todo o centro da página, a cor verde clara; c) na parte inferior, um azul degradê, puxando para o lilás. Preenchendo esses espaços, objetos e letras - de forma restritiva em tamanho e espaço - 
pequenos e delicados. Apenas o amarelo chama a atenção do enunciatário, como se fosse um grito. As demais cores têm tonalidades frias.

Ainda quanto ao efeito da claridade sobre a apreensão estética, ela

[...] remete a problemática da enunciação, a produção e a compreensão de um sentido e, sobretudo, a acepção por parte de um sujeito em posição de enunciatário, isto é, de destinatário do enunciado, das proposições contratuais que se consideram a verdade e as marcas do dizer-verdadeiro (FLOCH, 1993, p. 71).

Quanto à apreensão da figura pelo enunciatário, podemos dizer que este vê na figura visual "um relato de contrato e, com mais exatidão, de um contrato de veridicção" (FLOCH, 1993, p. 73).

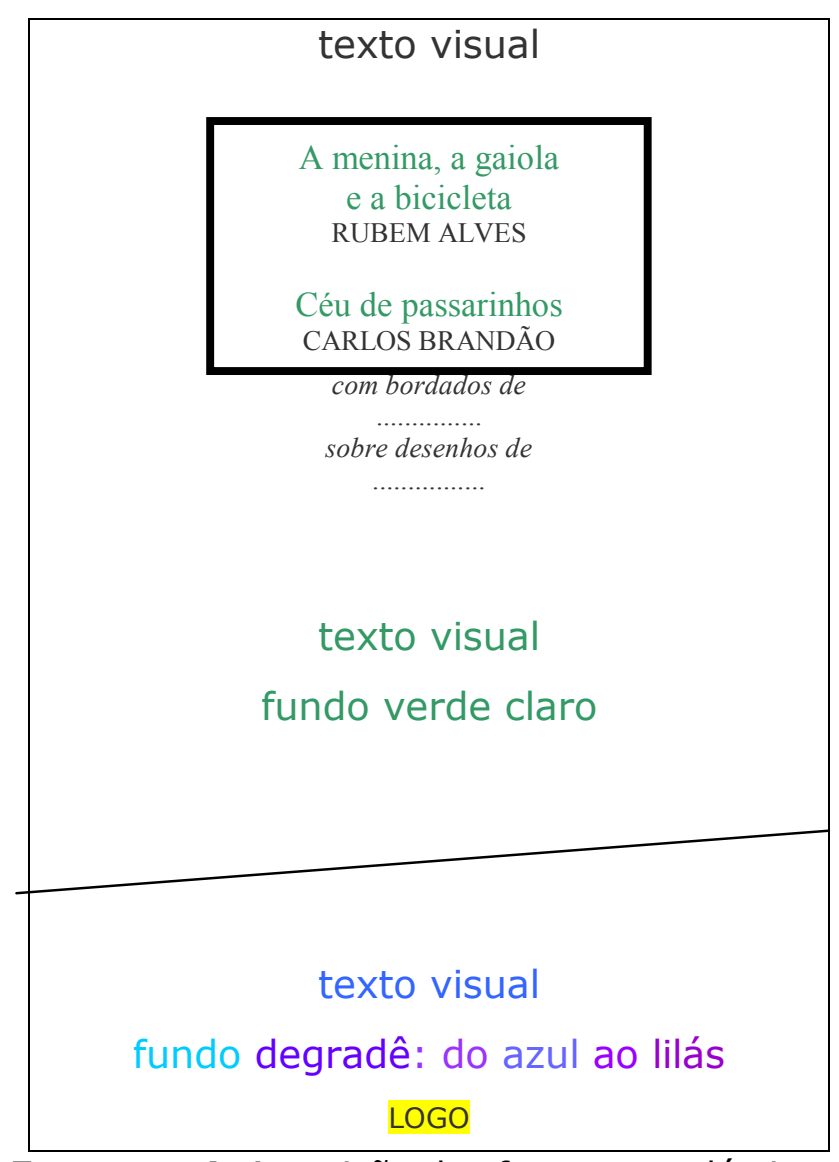

Esquema 4. A posição dos formantes plásticos. 
Ainda sobre as cores, observamos que as suas tonalidades suaves remetem ao universo infantil, pois, geralmente, são usadas para a decoração de quartos infantis e roupas de criança. Há uma leitura simbólica/cultural - imediata dos elementos cromáticos que permite às crianças uma leitura e uma identificação, como podemos observar nas disposições das cores no quadro acima.

Na questão eidética, predominam as linhas retas. Tanto os objetos, quanto os pontos de preenchimento dos bordados e a divisão cromática apresentam essas características. O tecido da parte inferior, por exemplo, tem estampa xadrez, de modo que, em que cada quadrado há uma tonalidade derivada do azul e, abaixo dele, há uma "borda" de vegetação inclinada para a esquerda, prevalecendo, assim, as linhas retas. A técnica do bordado cria ângulos, mesmo sobre objetos delicados, como folhas e galhos. Até mesmo as borboletas são feitas com a junção de dois triângulos ou de dois trapézios.

As formas arredondadas são rarefeitas na imagem. Há alguns elementos, como as duas rodas da bicicleta, as pequenas flores e as poucas libélulas. Os poás ${ }^{41}$ brancos, que possuem formas circulares, espalham-se em toda a extensão da ilustração, pontuando-a e atuando como pontos de luz/luminosidade. A respeito dessa luz, o filósofo Gilles Deleuze diz que "a energia da luz é ritmada pela ordem das formas" (2007, p. 127).

As letras também funcionam como um elemento gráfico curvilíneo. A fonte utilizada é a Times New Roman, que pertence à família tipografada serifada, isto é, com prolongamentos arredondados no fim das hastes das letras. Embora adicionem leveza pelo seu elemento decorativo serifado, essas letras são, na verdade, uma leitura da antiga tipografia clássica new roman. Temos, assim, um jogo óptico com as formas, nas quais podemos estabelecer a categoria rigidez $\mathrm{x}$ flexibilidade.

\footnotetext{
41 "Padrão de bolas espaçadas de maneira uniforme, estampado sobre algodão, linho, seda, voile e tecidos de fibras mistas" (O'HARA, 1992, p. 216).
} 
A visão frontal, acrescida da superfície plana, desencadeia o háptico, permitindo "ao olho proceder como o tocar, [...] Ihe impõe uma função tátil [...] que garante a reunião dos dois sentidos, o tato e a visão" (DELEUZE, 2005, p. 123). O efeito desse componente estético resulta numa imagem plana. As linhas não criam profundidade, isto porque "quanto mais livres do fundo, mais livres eles estão para o espaço, onde o olhar as acolhe e recolhe. Mas esse espaço jamais é o espaço livre que cerca e atravessa o espectador" (DELEUZE, 2007, p. 127).

$\mathrm{Na}$ categoria topológica, além da relação com os elementos cromáticos acima citados, observa-se uma concentração de figuras na parte inferior que vai se esvaziando no sentido vertical crescente. No topo da capa, há apenas poás brancos e um bloco amarelo que concentra parte do texto verbal, mas este retângulo está sobreposto ao desenho/bordado. Processo inverso ocorre com o texto verbal que se concentra na parte superior, no interior do retângulo, e vai diminuindo de tamanho até virar o logotipo da editora. As letras invadem o espaço imagético, mas sua localização é determinada topologicamente, não chegando a interferir nos elementos ilustrativos ou na narrativa visual.

No livro da Companhia das Letrinhas é visível os limites dos objetos e a visão que se tem de volumes e contornos que os isola. A luminosidade realça os tons e fixa os contornos, presentificando as formas. Embora a ilustração contenha vários objetos inseridos que formam um conjunto harmonioso, cada um deles detém certa autonomia e vida própria. Contudo, esses contornos estão "imunes ao acidente, à mudança, à deformação" (DELEUZE, 2005, p. 123).

Quanto à profundidade, vemos que se formam estratos planos, frontais para quem olha, isto é, para o enunciatário. E essa sensação de imagem plana se deve ao próprio estilo linear, pois a linha depende de um plano.

Podemos observar que os principais traços dessa obra se enquadram nas características do estilo clássico. 
O conceito básico do Renascimento italiano é o conceito de proporção perfeita. Na figura humana, tanto quanto nas edificações, esse período procurou obter a imagem da perfeição que repousa em si mesma. Cada uma das formas ganha uma existência autônoma e se articula livremente; são partes vivas, absolutamente independentes (WÖLFFLIN, 2000, p. 12).

\subsubsection{O plano da expressão na obra de Jorge Amado}

A capa do livro de Jorge Amado se apresenta de forma difusa e agitada, com imagens condensadas, congestionando o olhar com suas formas ilimitadas e excesso de informação. Aqui, desaparecem as proporções, o equilíbrio, abarcando formas pesadas e pouco articuladas, não havendo qualquer autonomia.

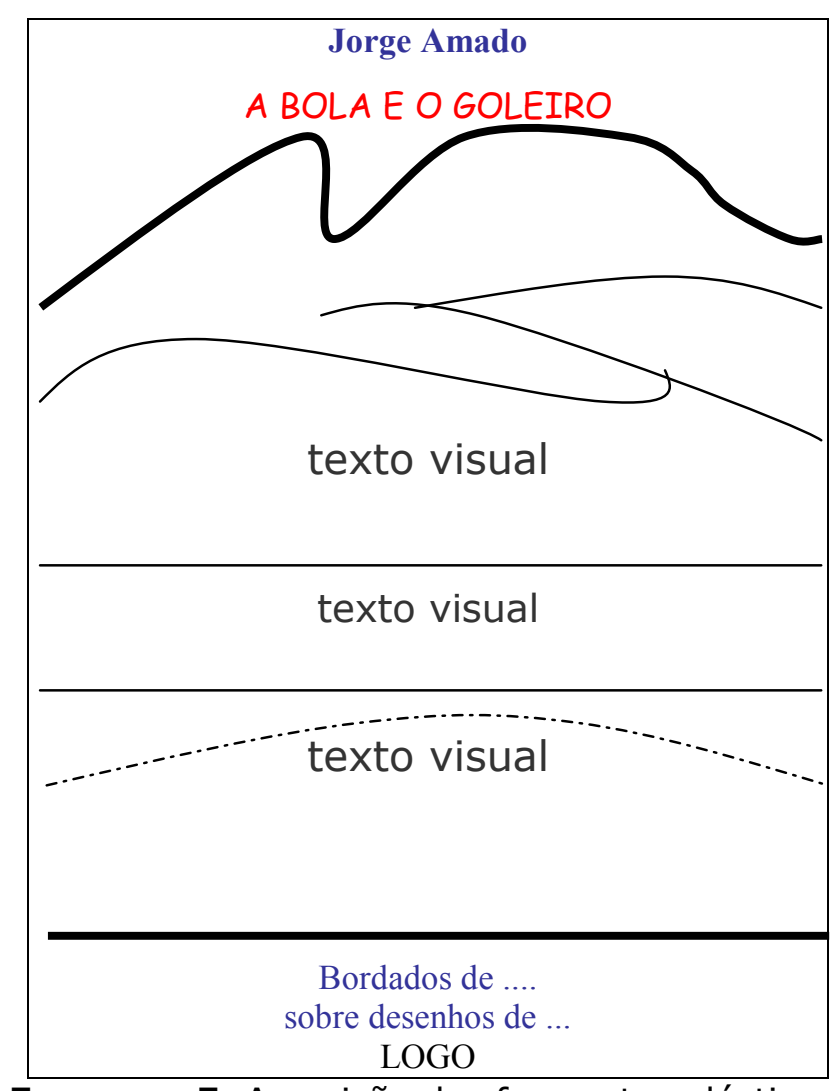

Esquema 5. A posição dos formantes plásticos. 
Começando com a categoria de relação topológica do livro, vemos que há uma separação total entre texto verbal e texto visual. Este, concentra-se em um só lugar na capa, no centro da ilustração, porém o espaço ocupado por ele é extenso; enquanto aquele, localiza-se nas duas extremidades da capa, ocupando um espaço restrito e descontínuo. O quadro acima esquematiza toda a descrição.

No imagético, as linhas e curvas impõem espaços que são divididos da seguinte forma: dois planos retos e dois curvos, embora um dos planos curvos seja pontilhado e sutil. Vejamos:

- No primeiro plano da imagem, na parte inferior, temos um campo de futebol e seus jogadores em um plano reto;

- No segundo, a torcida está separada do campo de futebol por uma estreita linha curva pontilhada;

- No terceiro, mais torcedores. A separação é feita por uma linha reta grossa;

- $E$, no quarto, a natureza - montanhas, árvores, vegetação, morro - e a cidade. A separação também é feita por uma linha reta larga.

Todos esses espaços estão completamente preenchidos com figuras: campo de futebol, jogadores, torcedores, bandeiras, fogos de artifício, serpentina ${ }^{42}$, casas, prédios, montanhas, morro, árvores e grama. $\mathrm{O}$ único ponto de escapatória visual é o espaço destinado ao textual.

Entretanto, é possível fazer duas divisões sutis tendo como critério os elementos cromático e topológico. Por meio do critério topológico, há uma separação de ambientes: na parte superior está a cidade com a natureza; e, na parte inferior, separada por uma grossa linha, o campo de futebol. Pelo cromático, temos três recortes: no topo, onde está a cidade

\footnotetext{
${ }^{42}$ Fita estreita, de papel colorido, com muitos metros de comprimento, enrolada sobre si mesma e que se desenrola quando arremessada, e que se usa, especialmente, nas festas de carnaval (Cf. DICIONÁRIO AURÉLIO, 2009).
} 
e a natureza, predominam as cores verde e amarela; no meio, o espaço é ocupado pela arquibancada e seus torcedores, além disso se sobressai a cor laranja; e, por fim, na base, as cores amarela e verde prevalecem sobre o campo de futebol. Podemos observar o esquema de cores no quadro seguinte.

\begin{tabular}{|c|c|}
\hline Verde e amarelo & cidade e natureza \\
\hline Iaranja & estádio de futebol \\
\hline Verde e amarelo & \\
\hline
\end{tabular}

Quadro 12. Divisão pelo plano da expressão e pelo plano do conteúdo.

Na questão eidética, subtraindo sua relação com o topológico como foi descrito acima, predominam as linhas curvas e arredondadas. Elas são tão preenchidas que criam um efeito óptico de volume e sombra. As árvores e o morro parecem saltar da ilustração. As bandeiras, com suas curvas, criam um efeito de movimento, de balanço. Há, assim, uma dinamicidade provocada pelos elementos eidéticos.

Com suas linhas em frenesi, perde-se a distinção de fundo e forma. Desta forma, "os ritmos de luz e de sombra que não respeitarão mais a integridade de uma forma plástica, mas farão surgir uma forma óptica saída do fundo" (DELEUZE, 2005, p. 128). Com esse procedimento, ocorre uma perda do háptico, pois "o tato não é mais convocado pelo olho" (DELEUZE, 2005, p. 128), ele se torna uma ação mecânica, que separa o tátil do óptico.

Ainda sobre o cromático, podemos verificar, na ilustração, uma grande variedade na cartela de cores. O jogo cromático cria um efeito de imagem com pouca claridade e nitidez. A presença exacerbada de objetos e cores forma um mesclado, um amalgamado. Esse exagero é o que provoca falta de luminosidade. 
No livro da editora Record, a imagem não tem limites, há um entrelaçamento, uma junção dos objetos, uma condensação. A linha é desvalorizada gradualmente, fazendo com que os objetos percam seus contornos. A preocupação maior é com a formação de uma massa uniforme que encadeie os objetos, proporcionando, assim, estabilidade e movimento. Tendo essa prioridade em mente, há uma perda dos contornos e das formas das figuras, como se pode observar no desenho dos torcedores na arquibancada. Somente com bastante atenção é possível ver os fogos de artifício explodindo e as serpentinas sendo arremessadas.

A profundidade, nessa ilustração, é relevante, desvalorizando o plano. O efeito de perspectiva e de sensação de espaço, com formas imprecisas e sombras, cria um movimento do olhar de frente para trás. A percepção é de união: as partes se subordinam a um elemento único. Dessa forma, a clareza é abolida, disponibilizando apenas alguns pontos básicos. Essa ilustração tem fortes traços da estética barroca.

O Barroco emprega o mesmo sistema de formas, mas em lugar do perfeito, do completo, oferece o agitado, o mutável; em lugar do limitado e concebível, o ilimitado é colossal. Desaparece o ideal da proporção bela e o interesse não se concentra mais no que é, mas no que acontece. As massas, pesadas e pouco articuladas, entram em movimento. A arquitetura deixa de ser o que fora no Renascimento, uma arte da articulação, e a composição do edifício, que antes dava a impressão da mais sublime liberdade, cede lugar a um conglomerado de partes sem qualquer autonomia (WÖLFFLIN, 2000, p. 12).

\subsubsection{As capas contrapostas}

Trabalhando com direções opostas, cada capa mostra sua força sob perspectivas diferentes. Enquanto na capa do livro $A$ bola e o goleiro, com características barrocas, vemos manchas e pouca nitidez, na capa do livro A menina, a gaiola e a bicicleta/Céu de passarinhos, de estilo clássico, as 
linhas são nítidas e claras. A sensação de vazio do estilo linear, por exemplo, é criada pelos tons claros extraídos de uma cartela de cores restritivas. Nesse caso, o verde e o azul atuam com simplificação e delicadeza nas linhas e nas formas. No plano pictórico, ao contrário, os traços são espessos e abruptos, com uma explosão de cores.

Encontramos mais oposições quando nos defrontamos com as formas de representação dos objetos. As linhas dos bordados da obra de Rubem Alves e Carlos Brandão são fechadas e, de certa maneira, rígidas, dando forma e definição aos objetos, além de ocupar espaços delimitados simetricamente. Em oposição, na obra de Jorge Amado, as linhas são fragmentadas, criando divisões pouco harmônicas.

Encontramos vários elementos de composição na ilustração do livro de Rubem Alves que se articulam entre si, mas preservam sua distinção, mantendo sua linguagem ou sua expressão própria. Há um ajuste harmonioso formando o todo. Entretanto, ao observarmos a capa do livro de Jorge Amado, há um bloco uniforme de massa, no qual as partes perdem sua autonomia e sua individualidade. Ele põe em destaque um motivo dominante, no caso, uma partida de futebol, em que os demais elementos ficam subordinados, tendo como efeito de sentido o instante e não a duração.

A harmonia estética desencadeia uma ação, o toque, resultante de um contrato de veridicção, de confirmação do sentido plástico. O destinatário/receptor, diante de sensações agradáveis geradas pelo efeito de sentido que as linhas e formas criam, como a delicadeza e a suavidade, tem uma relação de aproximação com o objeto. Segundo Kirchof, "as sensações enviadas pelo toque através dos dedos possuem a função original de mapear o mundo" (2008, p. 186).

No jogo óptico, vemos a valorização da luminosidade na capa clássica que revela as formas de todos os componentes plásticos: a bicicleta, a árvore, a grama, a estrada, uma pequena vegetação e o voo das borboletas e das libélulas. Na capa barroca ocorre o processo inverso, com a perda da claridade e presença de sombras. A luz é colocada de 
forma a distorcer o objeto. Dessa forma, vemos o gramado do campo de futebol, com pontos irregulares e disformes; e a largura e o comprimento da grande área desproporcionais.

Podemos notar, ainda, que o topológico é relevante nessas duas capas ao estabelecer relações distintas na construção de sentido. No livro da editora Companhia das Letrinhas, o topológico é submetido ao cromático, criando um efeito de estaticidade. Entretanto, no livro da editora Record, o topológico se submete ao eidético, gerando movimento.

Vemos, assim, que a percepção e a apreensão dos formantes plásticos são distintas para cada capa. Entram, nesse processo, a textura, a cor, a luz e a forma. Embora todos esses elementos atuem juntos, a luz, por exemplo, "define a cor que se refere a uma textura, determinando, ela mesma, a dimensão e a luminosidade do campo cromático" (BEYAERT, 2003-2004, p. 81).

Por sua vez, a textura é "uma qualidade visual que se entrelaça com a cor, com a luz e com o eidético" (BEYAERT, 2003-2004, p. 87), remetendo ao háptico, "a reunião de dois sentidos, o tato e a visão" (DELEUZE, 2007, p. 123).

Embora as capas sejam fotografias de bordados, isto é, sejam uma imagem plana, várias técnicas dessa arte popular são preservadas, remetendo a uma experiência táctil e/ou visual em maior ou menor grau. A apreensão é feita, então, pelo olhar que torna possível o tocar e o sentir.

Ocorre, num nível profundo, a síntese de diferentes ordens sensoriais, que se embaralham, misturam e acabam por produzir um efeito e imersão no objeto e perda da capacidade de discretizar, separar, categorizar. Tem-se de volta a fusão com o objeto (TEIXEIRA, 2009, p. 51). 
A tela de suporte de $A$ bola e o goleiro é de gorgorão ${ }^{43}$ na cor amarela, um tecido pesado que suporta melhor os bordados por ter mais elasticidade do que o algodão, por exemplo. Com um olhar atento, é possível observar os respiros do tecido, ou melhor, suas tramas, que formam leves ondulações (estrias). Sobre esse tecido encorpado, os bordados ocupam, topologicamente, toda a extensão da tela/tecido.

A trama do tecido, estriada, cria um efeito de aspereza, não estendendo a experiência do ver para a do tocar. O processo é interrompido. É pelas sensações, ou melhor, pelo estésico, que o enunciador e o enunciatário entram ou não em sintonia com uma experiência estética. "É o percurso da estesia que conduz o enunciatário pelos meandros da obra através de valores comuns, contrato e sanção que ele negocia e efetiva com o enunciador" (OLIVEIRA, 1995, p. 235).

Ao observarmos, porém, a tela de $A$ menina, a gaiola e a bicicleta, identificamos o tecido como sendo de linho ${ }^{44}$. Pela sua própria característica matérica, o linho tem pouca elasticidade, mas sua superfície é lisa, uniforme. O excesso de bordados provoca repuxes no tecido. Sendo assim, a quantidade de bordados sobre esse tipo de tecido é restrita. Novamente o háptico é acionado, pois através do olhar que "mostra" o objeto como liso, agradável ao toque, a ação de tocar se concretiza.

Em seu artigo sobre "O tratamento do material", Bastide (1987) explica que a materialidade impõe e limita a ação do sujeito sobre ela. Desta forma, o tipo de tecido determina e limita a ação do sujeito sobre

\footnotetext{
43 "Pode ser de algodão, seda ou misto com fibras sintéticas. Liso ou estampado, com canaletas finas. É utilizado em alta-costura e em estofamentos" (CHATAIGNIER, 2006, p. 147).

"Tecido de trama fechada, com estrias em relevo. Geralmente feito de seda" (O 'HARA, 1992, p. 131).

${ }^{44}$ Nome dado a qualquer tecido feito de fibra extraída da planta do mesmo nome. Forte, de superfície lisa, o linho varia em peso e textura. Dependendo da tecelagem, é possível fabricar linho tão fino quanto cambraia ou tão grosso quanto lona (O'HARA, 1992, p. 176).

"É uma fibra forte e durável, facilitando o tingimento e não encolhendo como o algodão" (CHATAIGNIER, 2006, p. 149).
} 
sua transformação e sua funcionalidade. Ao escolher o tipo de material, o sujeito está diante de uma limitação operatória de transformações, enquanto, no caso dos objetos analisados aqui, um permite a expansão (o gorgorão), o outro (o linho) só permite a condensação.

Voltando à capa do livro de Jorge Amado, as linhas que preenchem a tela contribuem significativamente para criar o efeito de volume no bordado. Não é real, claro, mas "a linha, através do seu papel, de sua função e de seu fazer articulado" (OLIVEIRA, 1999, p. 155), sugere isso. O quadro abaixo traz um resumo de algumas das características que já tratamos, comparando-as nos dois livros:

\begin{tabular}{|c|c|c|}
\hline & A bola e o goleiro & $\begin{array}{c}\text { A menina, a gaiola e a } \\
\text { bicicleta/Céu de passarinhos }\end{array}$ \\
\hline Eidético & instantâneo & $\begin{array}{c}\text { durativo } \\
\text { hesarmônico }\end{array}$ \\
\hline Topológico & dinâmico \\
& caótico & estático \\
\hline Cromático & escuridão & claridade \\
& jogo de sombra e luz & pontos de luz \\
\hline Estilo & Barroco & Clássico \\
\hline
\end{tabular}

Quadro 13. Identificação das características plásticas de cada capa de livro.

O matérico, o eidético, o cromático e o topológico são elementos e categorias de significação. "A totalidade do sentido de um objeto sincrético é processada pelo arranjo global de formantes de distintos sistemas, assim como de suas regras de distribuição e ordenação" (OLIVEIRA, 2009, p. 80).

Podemos, ainda, ressaltar algumas características das capas. Notamos que os elementos contidos nas categorias relacionadas ao estilo barroco apresentam, tensivamente, a expansão (abertura, esfriamento e dinamicidade). Entretanto, os elementos do estilo clássico são de contenção (fechamento, aquecimento e estaticidade). 
Ao articularmos esses dados tensivos do plano da expressão com o plano do conteúdo, encontramos uma oposição entre extensividade, relacionada à expansão, e intensidade, relacionada à contenção. Embora, seja bem verdade, essas variantes sofrem gradações.

Todos esses procedimentos de análises tiveram o intuito de chegar ao enunciatário infantil. $\mathrm{Na}$ verdade, mais do que isso, buscamos compreender os mecanismos enunciativos que levam uma criança a querer ter essa experiência com um livro. Não queremos mostrar, necessariamente, que haja sucesso nesses mecanismos de persuasão e manipulação. Como explica Carani (1996, p. 16), pelo processo enunciativo, ocorre "a manipulação da competência e da performance do sujeito receptor", executadas a partir da homologação, e não da conformidade, por correlação entre as categorias dos planos do conteúdo e da expressão.

O êxito dessa homologação traz "a novidade e a poeticidade". "Os semi-simbolismos, de um certo tipo, produzem efeitos de poeticidade e, levados às últimas instâncias, faz do texto um objeto de prazer estético" (BARROS, 2005b, p. 156).

Em um único livro, o enunciatário está diante de uma gama de informações de mundo fornecidas de forma lúdica e poética. Mais do que ler e ver imagens, a experiência da criança com livros-arte lhes abre as portas do saber e do criar.

A arte - em suas várias esferas de atuação e manifestação - busca instigar a curiosidade e a compreensão de mundo, criando novos sentidos e oferecendo uma nova leitura do mundo. Segundo Kirchof, a relação com a arte começa pelo "comportamento da curiosidade", isto é, "explorar ao máximo o mundo externo e, dessa maneira, produzir conhecimentos que possam ser perfeitamente úteis" (2008, p. 47). Num segundo momento, por meio da ação, é despertado o "comportamento explorativo", "permitindo o conhecimento do mundo externo" (KIRCHOF, 2008, p. 47). Por fim, em um terceiro momento, mais relevante à experiência estética, a experiência com a arte acontece quando não há uma finalidade final 
específica, gerando o "comportamento lúdico", que tem como objetivo último, o aprendizado ligado ao prazer funcional, buscando "a espontaneidade e, consequentemente, a criatividade" (KIRCHOF, 2008, p. 47).

Esse mesmo processo ocorre quando uma criança tem diante de si um livro. Sua curiosidade é despertada pela ilustração da capa, porta de entrada para a experiência estética. A ação de olhá-lo, tocá-lo, experimentá-lo, lê-lo mostra a função útil do objeto-livro. Se a experiência continuar de forma prazerosa e lúdica, a criança terá em suas mãos um livro-arte, em sua mais genuína concepção. 


\section{CONCLUSÃO}

"As coisas sem importância são bens de poesia." Manoel de Barros ${ }^{45}$

Os livros literários destinados ao público infanto-juvenil têm, atualmente, no Brasil, um forte apelo visual, com projetos gráficos inusitados e ilustrações inspiradas nas artes plásticas. Dialogando com os estilos e os modismos que vão surgindo a cada década ou período, essas obras revelam, ou até mesmo resgatam, a memória coletiva de uma sociedade e seus anseios, demarcando uma época.

$\mathrm{Na}$ década de 1990, observa-se no mercado literário brasileiro um grande interesse em se recuperar a arte popular, resgatando sua história e seu valor. Surgem nas prateleiras das livrarias publicações ilustradas com fotografias de bordados, e que dialogam com textos que remetem à infância, ao amadurecimento, a valores éticos e religiosos, à cultura local e a própria arte de bordar.

O interesse acadêmico pelos gêneros literários infanto-juvenis é crescente, mas os trabalhos que utilizam a teoria da semiótica francesa são ainda muito escassos, limitando-se, muitas vezes, à análise do texto verbal, subtraindo o papel e a importância da capa e das ilustrações no processo de apreensão estética e também como mecanismo de depreensão de sentido. São escassos ainda, trabalhos que privilegiem a relação entre as ilustrações com o texto escrito, criando um texto único, sincrético, em uma única enunciação. As propostas atuais com base nessa teoria vêm "considerando os códigos particulares dos textos que examinam: semiótica plástica, semiótica da canção, semiótica da literatura" (TEIXEIRA, 2009, p. 44), permitindo abrir o leque da significação.

45 BARROS, Manoel de. Matéria de poesia. Rio de Janeiro: Record, 2007, 6a edição, p.15. 
Dessa forma, nos apropriamos da semiótica greimasiana como ferramenta teórica para a análise do corpus dessa tese. Utilizamos a tensividade, sob domínio de Jacques Fontanille e Claude Zilberberg; a figuratividade, tão presente e marcante neste trabalho, embasada nos trabalhos e propostas de Denis Bertrand, nos permitiram "localizar no discurso o efeito de sentido particular que consiste em tornar sensível a realidade sensível" (2003, p. 154). Outro suporte importante a esse trabalho é Jean-Marie Floch, com suas linhas de pesquisa a respeito do visual/pictórico, propondo novas categorias (constitucionais e relacionais) de análise para o plano da expressão.

Como a própria natureza dos objetos analisados atua no sensível "mediante práticas cotidianas", seguimos o caminho do estético partindo do olhar que Algirdas Julien Greimas dá a esses textos-objeto na obra $D a$ Imperfeição, em que o plano da expressão passa a ser a força motriz da obra, depreendendo seu sentido e seu sensível, mostrando a "elasticidade do discurso", que vai bem mais além da superfície do texto. "Mais que uma propriedade da língua, a elasticidade é característica do discurso, podendo manifestar-se por meio de qualquer substância da expressão" (LOPES, 2003, p. 67).

$\mathrm{Na}$ análise dos objetos plásticos, buscamos outras fontes teóricas com o intuito de enriquecer e expandir as análises, procurando sempre manter o intercâmbio entre a semiótica e as outras propostas de análise do pictórico. Diante das informações técnicas das artes plásticas, que possuem uma linguagem própria, procuramos mostrar uma "grade de leitura" dos textos-objeto.

Respeitando esse estatuto, nos fundamentamos na semiótica francesa com o intuito de analisar esses textos visuais trazendo a significação através dos seus formantes plásticos, como as modulações de sombras e cores, formas, volume, linhas, distribuição de superfícies e relevo. Esses elementos plásticos dialogam ou não com os textos verbais, conforme a análise feita sobre cada livro. 
Iniciamos o exercício prático com a teoria das paixões no livro $A$ Moça Tecelã, de Marina Colasanti. A análise se limitou ao texto verbal, pois buscamos focar a significação das paixões que, através das relações modais, cria efeitos de sentido gerados pelos estados patêmicos que alteram o percurso do sujeito. A metodologia adotada foi dividir o texto em três partes, conforme as mudanças tímicas e de estado do sujeito, mostrando sequências de estados afetivos de forma gradual e tensiva.

Na sequência, temos a obra de Manoel de Barros, Exercício de ser Criança, em que a enunciação permeia toda a análise. Trabalhando com as duas linguagens - verbal e visual - encontramos uma enunciação única em que o texto visual ora confirma o enunciado textual, ora expande sua compreensão. Tendo como suporte principal o livro As Astúcias da Enunciação, de José Luiz Fiorin, são descritas as estratégias de enunciação, apontando os recursos utilizados para a sua construção.

O terceiro livro analisado é Menino do rio Doce, de Ziraldo, que percorre o universo das paixões, do estésico e da intertextualidade ao dialogar com os personagens juvenis e o mundo ribeirinho das obras do escritor norte-americano Mark Twain. Trabalhando com o verbal e o visual, pudemos extrair os eventos sensoriais da percepção e delimitar como esses atuam na construção afetiva dos personagens. Os encontros intertextuais e interdiscursivos dessa obra vão além do texto verbal, de tal forma que possam ser pontuadas descrições no texto visual com as obras do escritor norte-americano.

Fechando este trabalho, unimos duas obras, ou melhor, duas capas de livros: A Bola e o Goleiro, de Jorge Amado, e A Menina, a Gaiola e a Bicicleta/Céu de Passarinhos, de Rubem Alves e Carlos Brandão, adotando a semiótica plástica como base. Optamos por fazer um trabalho comparativo, identificando os elementos em comum e aqueles que os diferenciam. Lembrando que as propostas teóricas e metodológicas de Jean-Marie Floch direcionam este trabalho, acrescentando a elas um olhar tensivo, sob a tutela de Fontanille (2005). Esse último explica que "a análise dos formantes plásticos deve começar pela pesquisa dos 
conteúdos e dos valores próprios do visível, antes mesmo de identificar as figuras da representação" (FONTANILLE, 2005, p. 162).

Vale ressaltar que, embora este trabalho trilhe pelo caminho da semiótica, fez-se necessário oferecer informações históricas e didáticas sobre a produção de livros para o público infanto-juvenil no Brasil e no exterior, mostrando sua evolução e importância no mercado editorial e na sociedade. O que explica o acréscimo de livros sobre esse universo, incluindo obras específicas sobre literatura infantil, ilustração e diagramação.

Os exercícios teóricos praticados nessa dissertação mostram a amplitude da teoria semiótica francesa que consegue abarcar diferentes objetos-texto. Essa teoria, ao oferecer ao pesquisador várias ferramentas teóricas que se ajustam ao texto analisado, como a figuratividade, a enunciação, a plasticidade, as paixões, "explica as estruturas significantes que modelam o discurso social e o discurso individual, $[\ldots]$ mostrando as relações estruturais, subjacentes e reconstruíveis, que produzem significação" (BERTRAND, 2003, p. 15).

Sendo uma teoria da significação, a semiótica se preocupa em explicar, metodologicamente, "as condições da apreensão e da produção do sentido" (BERTRAND, 2003, p. 16). Dessa forma, para cada objeto analisado buscamos adotar ferramentas que extraíssem o máximo da compreensão daquele texto-objeto. Na obra $A$ moça tecelã, encontramos uma forte carga afetiva que, pelo próprio texto, impunha um caminho para trabalhá-lo, no caso, a semiótica das paixões. Na análise de textos visuais, a semiótica plástica apresentou uma metodologia que depreende o texto em sua totalidade, seja pelo plano da expressão, seja pelo plano do conteúdo.

Todo esse suporte teórico serviu para mostrar o potencial de leitura que o livro infantil tem e/ou pode desencadear. A leitura começa pela capa, mas esta é apenas a porta de entrada, o cartão-postal. Ao entrar no 
livro, o enunciatário fica diante de ilustrações que não servem apenas como suporte ou ancoragem do texto verbal. Mais do que isso, ele fica diante de imagens, conforme as análises mostraram, que atuam com autonomia, tendo uma narrativa própria, confirmando ou expandindo a leitura do texto verbal. Várias lacunas deixadas pelo texto verbal são preenchidas pelo texto visual, igualando a importância da ilustração como elemento de construção de sentido e de apreensão do texto.

Esperamos que este trabalho possa contribuir com os estudos dos textos literários e plásticos infanto-juvenis, apontando possíveis leituras, tendo como ferramenta teórica a semiótica discursiva. 


\section{REFERÊNCIAS BIBLIOGRÁFICAS}

ALVES, Rubens. Os três reis. São Paulo: Loyola, 2004.

; BRANDÃO, Carlos Rodrigues. $5^{a}$ reimp. A menina, a gaiola e a bicicleta/Céu de passarinhos. São Paulo: Companhia das Letrinhas, 2004.

AMADO, Jorge. A bola e o goleiro. $14^{\mathrm{a}}$ ed. Rio de Janeiro: Record, 2007. AMOSSY, Ruth (org). Imagens de si no discurso: a construção do ethos. Tradução de Dilson Ferreira da Cruz, Fabiana Komesu e Sírio Possenti. São Paulo: Contexto, 2005.

BAKHTIN, Mikhail/ VOLOCHINOV. Marxismo e filosofia da linguagem. Tradução de Michel Lahud e Yara Frateschi Vieira. $12^{a}$ ed. São Paulo: Hucitec, 2006. (Linguagem e Cultura, 3).

BARROS, Diana Luz Pessoa de. Paixões e apaixonados: exame semiótico de alguns percursos. Cruzeiro Semiótico, Porto, Portugal, no 11-12, janeiro, 1990.

. Teoria semiótica do texto. $4^{a}$ ed. São Paulo: Ática, 2005.

- Procedimientos del plano de la expresión y construcción de los sentidos. In: Semiótica de lo visual: Tópicos del seminario, $\mathrm{n}^{0} 13, \mathrm{p}$. 137-157, 2005b.

FIORIN, José Luiz (orgs). Dialogismo, polifonia, intertextualidade: em torno de Bakhtin. $2^{\text {a }}$ ed. São Paulo: Edusp, 2003. (Ensaios de Cultura 7).

BARROS, Manoel de. Exercícios de ser criança. Rio de Janeiro: Salamandra, 1999.

. Memórias inventadas: a infância. $2^{a}$ reimpressão. São Paulo: Planeta, 2007.

. Memórias inventadas: a segunda infância. $1^{\text {a }}$ reimpressão. São Paulo: Planeta, 2007.

. O livro das ignorãças. Rio de Janeiro: Record, 2007. 
Matéria de Poesia. $6^{\mathrm{a}}$ ed. Rio de Janeiro: Record, 2007.

BASTIDE, Françoise. Le traitement de la matière. Actes Sémiotiques Documents, Paris: Centre national de la recherche scientifique, $1987 / 1988$.

BEYAERT, Anne. Plasticité et signification: le cas d'Eugène Leroy, Protée, vol. 27, n², p.125-131, 1999.

.Texture, couleur, lumière etautres arrangements de la perception, Protée, vol.31, n³, p. 81-90, 2003/04.

BEYAERT-GESLIN, Anne. La typographie dans le collage cubiste: de I'écriture à la texture. In: Sémantiques - L'écriture entre support et surface. Limoges-França: L'Harmattan, 2005, p. 131-151.

. La conversión de tocar en ver, Semiótica de lo visual: Tópicos del seminario, $\mathrm{n}^{0} 13, \mathrm{p} .91-111,2005 \mathrm{~b}$.

BERTRAND, Denis. Caminhos da semiótica literária. Tradução do Grupo CASA. Bauru, SP: EDUSC, 2003.

Narratividade e discursividade: pontos de referência e problemáticas. Tradução de Ivã Carlos Lopes, Revista Significação, Annablume, n019, julho 2003.

BORBA, Francisco S. (org). Dicionário UNESP do português contemporâneo. São Paulo: UNESP, 2004.

CADERNOS de Tipografia, n02 e n03. Disponível em: < http://tipografos.net/tipos/fontes-para-crian\%E7as.html>. Acesso em: 28 dez. 2007.

CARANI, Marie. La sémiotiqte visuelle, le plastique et l'espace du proche. Protée, vol. 24, $\mathrm{n}^{\circ}$ 1, p. 16-23, 1996.

CAROTENUTO, Aldo. Eros e pathos: amor e sofrimento. Tradução de Isabel F. L. Ferreira. 2a ed. São Paulo: Paulus, 2005.

CECCANTINI, João Luís C. T. (org). Leitura e literatura infanto-juvenil: memória de gramado. Assis, SP: Cultura Acadêmica, 2004.

CHATAIGNIER, Gilda. Fio a fio: tecidos, moda e linguagem. São Paulo: Estação das Letras, 2006.

COLASSANTI, Marina. A moça tecelã. São Paulo: Global, 2004. 
DELEUZE, Gilles. Francis Bacon: lógica da sensação. Tradução de Roberto Machado (coord.). Rio de Janeiro: Jorge Zahar, 2007. (estéticas) DISCINI, Norma. O estilo nos textos. $2^{a}$ ed. São Paulo: Contexto, 2004. . Intertextualidade e conto maravilhoso. $2^{a}$ ed. São Paulo: Humanitas, 2004.

FERREIRA, Aurélio Buarque de Holanda. Novo dicionário Aurélio de língua portuguesa. $4^{\mathrm{a}}$ ed. Curitiba: Positivo, 2009.

FIORIN, José Luiz. A lógica da neutralidade: um caso de aspectualização do ator, Estudos Linguísticos XVIII - Anais de seminários do GEL, Lorena (SP), 1989.

- As astúcias da enunciação: as categorias de pessoa, espaço e tempo. 2a ed. São Paulo: Ática, 2002.

- Gêneros e tipos textuais. In: Hugo Mari; Ivete Walty; Zélia Versiani. (Org.). Ensaios sobre leitura. 1 ed. Belo Horizonte: Editora da PUCMinas, 2005, v. 1, p. 101-117.

- Prefácio. In: BEIVIDAS, Waldir. Semióticas sincréticas: o cinema. Posições. Edição online. Departamento Nacional do Livro/Agência Brasileiro do ISBN, julho 2006. Disponível em: <http://www.fflch.usp.br/dl/semiotica/downloads/beividas_semioticassinc reticas.pdf>. Acesso em: 28 nov. 2009.

FLOCH, Jean-Marie. Identités visuelles. Paris: PUF, 1998.

- Petites mythologies de lóeil et de l'esprit: pour une sémiotique plastique. Actes Sémiotiques, Paris-Amsterdam: Hadès-Benjamins, 1985. (Actes Sémiotiques).

Semiótica, marketing y comunicación: bajo los signos, las estrategias. Traducción de Maria del Rosario Lacelle y Maria Francisca Fernández. Barcelona: Ediciones Paidos, 1993.

FRANCO, Simone. Intertextualidade iconográfica. Revista Significação, São Paulo, Annablume, n²1, p. 207-220, junho 2004.

FONTANILLE, Jacques e ZILBERBERG, Claude. Tensão e Significação. Tradução de Ivã Carlos Lopes, Luiz Tatit e Waldir Beividas. São Paulo: Discurso Editorial Humanitas/FFLCH/USP, 2001. 
FONTANILLE, Jacques. Significação e visualidade: exercícios práticos. Tradução de Elizabeth Bastos Duarte e Maria Lília Dias de Castro. Porto Alegre: Sulina, 2005. (Estudos sobre audiovisuais, v. 3).

Semiótica do Discurso. Tradução de Jean Cristtus Portela. São Paulo: Contexto, 2007.

GREGORIN FILHO, José Nicolau. A roupa infantil da literatura. Dissertação de mestrado. São Paulo: Unesp, Araraquara, 1995. GREIMAS, Algirdas Julien. Sobre o sentido. Petrópolis, RJ: Vozes, 1975. . De la colère. In: Du Sens II, Essais sémiotique. Paris, Seuil, 1983.

. Da imperfeição. Tradução de Ana Claudia de Oliveira. São Paulo: Hacker Editores, 2002.

- Semiótica figurativa e semiótica plástica. In: OLIVEIRA, Ana Claúdia (org). Semiótica plástica. São Paulo: Hacker Editores, 2004, p. 75-96.

; COURTÉS, Joseph. Dicionário de semiótica. Tradução de Alceu Dias Lima, Diana Luz Pessoa de Barros e outros. São Paulo: Cultrix, s.d.

e FONTANILLE, Jacques. Semiótica das Paixões: dos estados de coisas aos estados de alma. Tradução de Maria José Rodrigues Coracini. São Paulo: Ática, 1993.

HARKOT-DE-LA-TAILLE, Elizabeth. Ensaio semiótico sobre a vergonha. São Paulo: Humanitas/FFLCH/USP, 1999.

HENDEL, Richard. O design do livro. $2^{a}$ ed. Tradução de Geraldo Gerson de Souza e Lúcio Manfredi. São Paulo: Ateliê Editorial, 2006.

HOUAISS, Antonio (ed.) Dicionário online Houaiss. Disponível em: <http://houaiss.uol.com.br/busca.jhtm>. Acesso em: 01 jan. 2008.

KIRCHOF, Edgar Roberto. Estética e biossemiótica. Porto Alegre: EDIPUCRS, 2008. (Coleção Humanidades 3).

LINS, Guto. Livro infantil? Projeto gráfico, metodologia, subjetividade. $2^{a}$ ed. São Paulo: Edições Rosari, 2004. (Coleção Textos Design).

LOPES, Ivã Carlos. Entre expressão e conteúdo: movimentos de expansão e condensação, Itinerários, Araraquara, n 20, 2003. 
A noção de 'profundidade' da semiótica. Cadernos de Semiótica Aplicada (CASA), vol. 4, n. 2, Araraquara (SP), Dezembro 2006. Semestral. Disponível em:

<http://www.fclar.unesp.br/grupos/casa/artigos/V4n2/CASA2006-v4n2Art-Lopes.pdf>. Acesso em 27 nov. 2008.

MACHADO, Ana Maria. Texturas: sobre leituras e escritos. Rio de Janeiro: Nova Fronteira, 2001.

. Ponto a ponto. São Paulo: Cia das Letrinhas, 2006.

MELLO, Thiago de. Amazonas: águas, pássaros, seres e milagres. $11^{a}$ impressão. Rio de Janeiro: Salamandra, 2007.

O'HARA, Georgina. Enciclopédia da moda: de 1840 à década de 80 . Trad. Glória Maria de Mello Carvalho. São Paulo: Companhia das Letras, 1992.

OLIVEIRA, Ana Claudia de (org). Semiótica plástica. São Paulo: Hacker Editores, 2004, p. 115-158.

. Prefácio. In: GREIMAS, Algirdas Julien. Da imperfeição. Tradução de Ana Claudia de Oliveira. São Paulo: Hacker Editores, 2002 , p. 9-14. OLIVEIRA, Ana Claudia de; TEIXEIRA, Lucia (orgs). Linguagens na comunicação: desenvolvimentos de semiótica sincrética. São Paulo: Estação das Letras e Cores, 2009.

; LANDOWSKI, Eric (eds.). Do inteligível ao sensível: em torno da obra de Algirdas Julien Greimas. São Paulo: EDUC, 1995.

; LANDOWSKI, Eric; DORRA, Raúl (eds). Semiótica, estesis, estética. São Paulo: EDUC/Puebla: UAP, 1999.

POWERS, Alan. Era uma vez uma capa. Tradução de Otacílio Nunes. São Paulo: Cosac Naif, 2008.

TEIXEIRA, Lúcia. Entre dispersão e acúmulo: para uma metodologia de análise de textos sincréticos. CPS-PUC/SP, sd. Disponível em: <http://www.pucsp.br/cps/pt-br/arquivo/Biblio-Lucia2.pdf>. Acesso em: 02 dez. 2009. 
- Station Bourse: o que os olhos não viram. In: CORTINA, Arnaldo;MARCHEZAN, Renata Coelho (org). Razões e sensibilidades: a semiótica em foco. Araraquara: Laboratório Editorial/FCL/UNESP; São Paulo: Cultura Acadêmica, 2004, p-. 221-247. (Série Trilhas Linguísticas, $6)$.

TWAIN, Mark. As aventuras de Huckleberry Finn. Tradução de Monteiro Lobato. São Paulo: Companhia Editora Nacional, 2005. (Clássicos Nacional).

As aventuras de Tom Sawyer. Tradução de Jean Melville. São Paulo: Martin Claret, 2007.

. The Adventures of Tom Sawyer. Estados Unidos: American Publishing Company, 1876. (online). Disponível em: $<$ http://en.wikipedia.org/wiki/Image:Tom_Sawyer_1876_frontispiece.jpg >. Acesso: 08 jan. 2009.

. The Adventures of Huchleberry Finn. Estados Unidos: Charles L. Webster and Company, 1884. (online). Disponível em: <http://etext.virginia.edu/twain/twaillus1.html>. Acesso: 08 jan. 2009. VALENTE, André. Intertextualidade e interdiscursividade nas linguagens midiáticas e literária: um encontro luso-brasileiro. In: OLIVEIRA, Fátima; DUARTE, Isabel Margarida. (Org.). O Fascínio da Linguagem. Actas do Colóquio de Homenagem a Fernanda Irene Fonseca. 1 ed. Porto: Centro de Linguística da Universidade do Porto/Faculdade de Letras da Universidade do Porto, 2008, v. 1, p. 79-89. Disponível em: $<$ http://ler.letras.up.pt/uploads/ficheiros/6694.pdf>. Acesso em: $02 \mathrm{dez}$. 2009.

WÖLFFLIN, Heinrich. Conceitos fundamentais da história da arte. São Paulo: Martins Fontes, 2000.

ZILBERMAN, Regina e LAJOLO, Marisa. Literatura infantil brasileira: histórias e histórias. São Paulo: Ática, 2006, 6ª edição.

ZIRALDO. Menino do rio doce. $12^{a}$ reimpressão. São Paulo: Companhia das Letrinhas, 2006. 
ANEXOS 


\section{CAPAS DOS LIVROS INFANTO-JUVENIS BORDADOS E ILUSTRADOS PELO GRUPO MATIZES}

Fonte: site oficial do grupo (http://www.matizesbordadosdumont.com/)

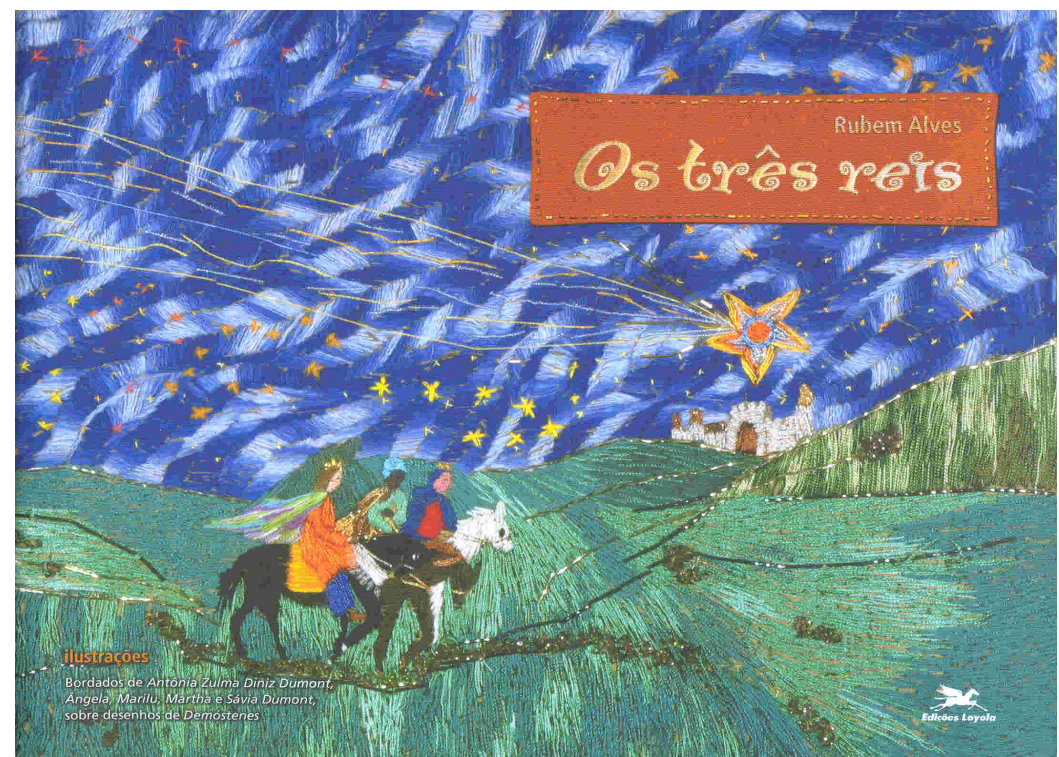

Os Três Reis

Autor: Rubem Alves

Editora: Loyola

Ano: 2004

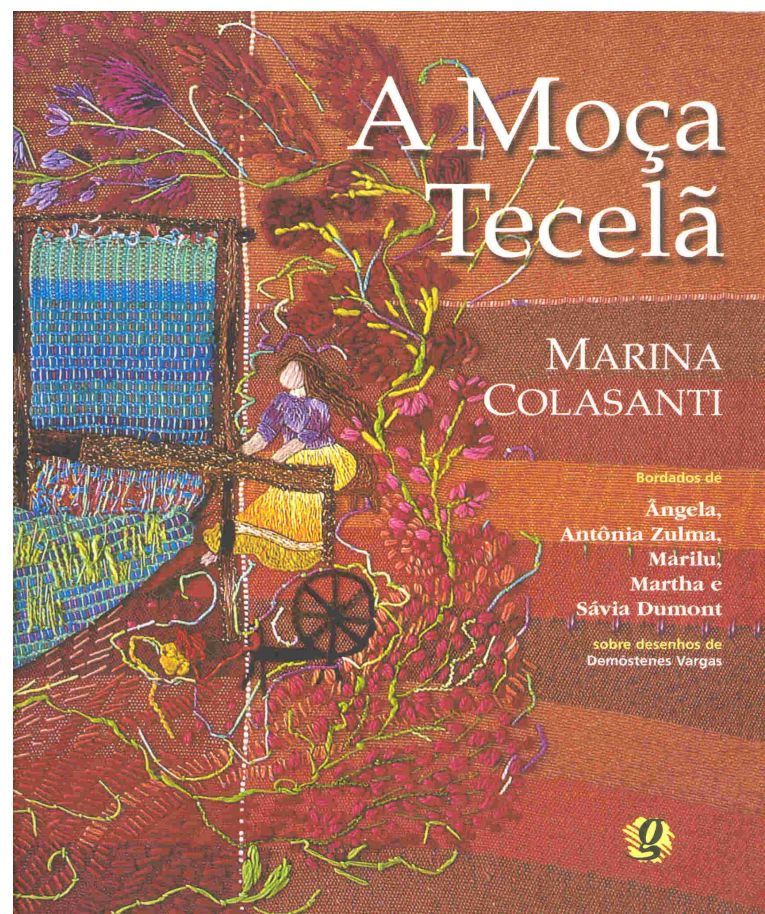

A Moça Tecelã

Autora: Marina Colasanti Editora: Global Ano: 2003

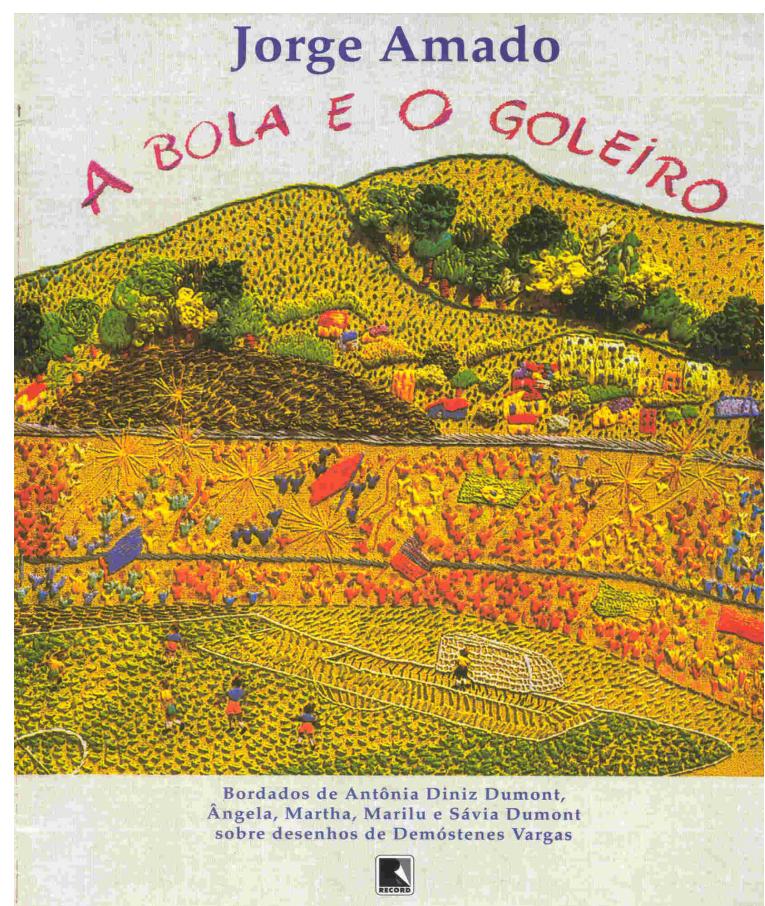

A Bola e o Goleiro Autor: Jorge Amado Editora: Record Ano: 2000 


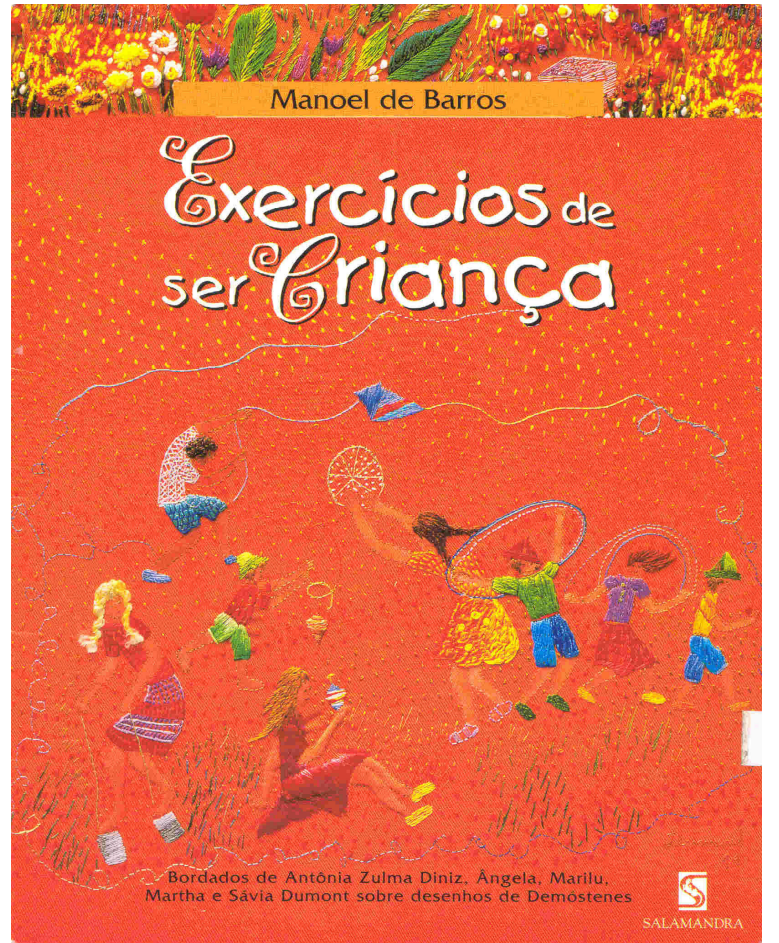

Exercícios de Ser Criança Autor: Manuel de Barros Editora: Salamandra Ano: 1999

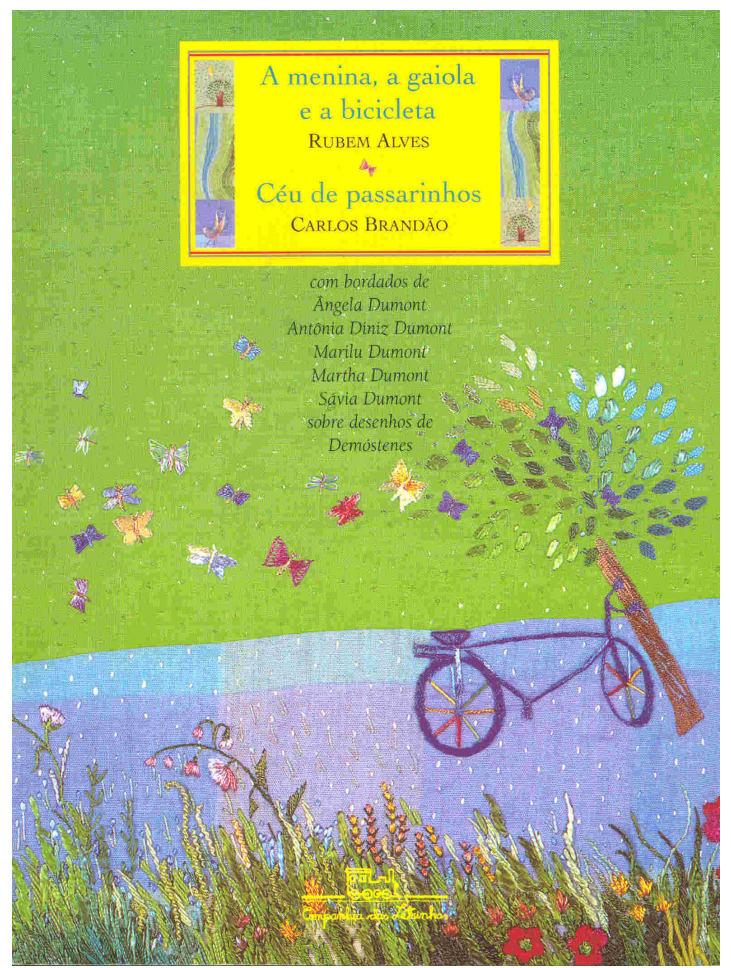

A Menina a Gaiola e a Bicicleta/ Céu de Passarinhos

Autores: Rubem Alves e Carlos Rodrigues Brandão

Editora: Companhia das Letrinhas Ano: 1997

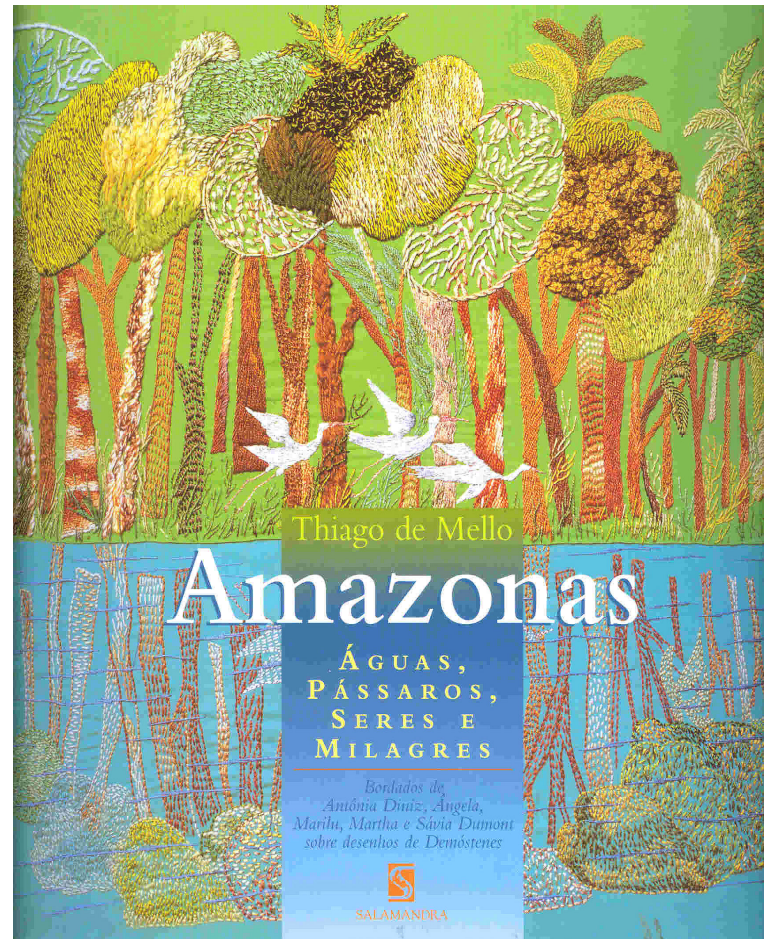

Amazonas Águas, pássaros, seres e milagres

Autor: Thiago de Melo Editora: Salamandra Ano: 1998

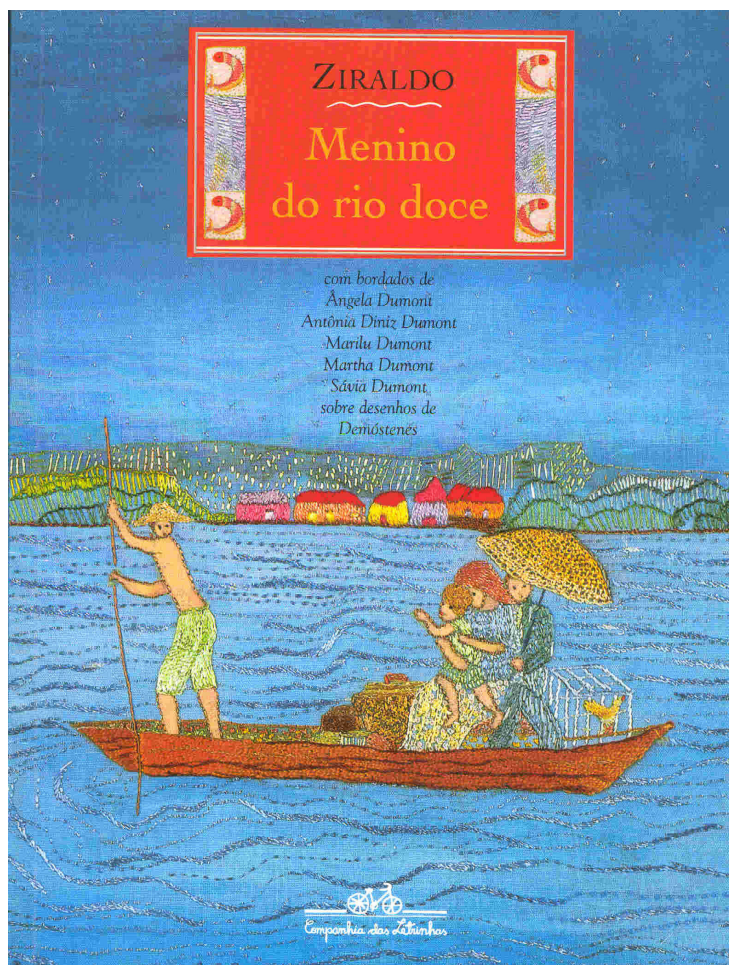

Menino do Rio Doce Autor: Ziraldo

Editora: Companhia das Letrinhas Ano: 1996 


\section{PRÊMIOS AO GRUPO MATIZES}

Fonte: site oficial do grupo

(http://www.matizesbordadosdumont.com/portu/premios.asp)

\section{0}

1. Prêmio Jabuti de Ilustração - Câmara Brasileira do Livro Livro: Exercícios de ser criança

2. Prêmio Adolfo Aizen de Melhor Projeto Gráfico e Ilustração - União Brasileira de Escritores

Livro: Amazonas, águas, pássaros, seres e milagres.

3. Selo de Altamente recomendável - Fundação Nacional do Livro Infanto Juvenil (FNLIJ)

Livros: Exercícios de ser criança

Amazonas, águas, pássaros, seres e milagres.

\section{9}

1. Lista de honra do IBY (International Book for Yang People)

Livro: Amazonas, águas, pássaros, seres e milagres.

2. Selo de Altamente Recomendável - Fundação Nacional do Livro Infanto Juvenil (FNLIJ)

Livro: Amazonas, águas, pássaros, seres e milagres.

\section{8}

1. Prêmio Jabuti de Ilustração - Câmara Brasileira do Livro

Livro: A menina a gaiola e a bicicleta/Céu de passarinhos

2. Prêmio Melhor Projeto Editorial - Fundação Nacional do Livro Infantil e Juvenil (FNLIJ)

Livro: Amazonas, águas, pássaros, seres e milagres.

3. Selo de Altamente Recomendável - Fundação Nacional do Livro Infanto Juvenil (FNLIJ) 
Livros: A menina a gaiola e a bicicleta/céu de passarinhos.

Amazonas, águas, pássaros, seres e milagres.

Matizes

\section{7}

1. Prêmio Melhor Ilustração - Bloch de Educação e Cultura

Livro: O Menino do Rio Doce.

2. Prêmio Melhor Projeto Editorial - Fundação Nacional do Livro Infantil e Juvenil (FNLIJ)

Livro: O Menino do Rio Doce

3. Prêmio Ofélia Fontes - Fundação Nacional do Livro Infantil e Juvenil (FNLIJ)

Livro: O menino do Rio Doce

4. Prêmio Revelação de Ilustração - Fundação Nacional do Livro Infantil e Juvenil (FNLIJ)

Livro: O menino do Rio Doce

5. Selo de Altamente Recomendável - Fundação Nacional do Livro Infanto Juvenil (FNLIJ)

Livro: O menino do Rio Doce 


\section{PREMIAÇÕES JABUTI}

Fonte: Câmara Brasileiro do Livro

Endereço eletrônico: (http://www.cbl.org.br)

\section{Prêmio 1959}

- Prêmio Personalidade Literária do Ano

Sérgio Milliet

- Categoria Contos / Crônicas / Novelas

Água Preta - Jorge Medauar

- Categoria Estudos Literários (Ensaios)

A Cidade de São Paulo - Estudos de Geografia Urbana Associação dos Geógrafos Brasileiros (Seção São Paulo)

- Categoria História Literária

História do Modernismo Brasileiro - Mário da Silva Brito

- Categoria Ilustrações

A Cidade do Salvador - Carlos Bastos

- Categoria Literatura Infantil

Aventuras na Roca - Renato Sêneca Fleury

- Categoria Literatura Juvenil

Glorinha - Isa Silveira Leal

- Categoria Romance

Gabriela, Cravo e Canela - Jorge Amado

\section{Prêmio 1995}

- Livro do Ano de Fiç̧ão

O Chalaça - José Roberto Torero

- Livro do Ano de Não-Ficção

O Brasil que dá Certo - Stephen Charles Kanitz

- Categoria Capista

A Porteira do Mundo - Leonardo Gomes 
Ex-Votos Mineiros: As Tábuas Votivas no Ciclo do Ouro - Victor Burton

Letras Francesas - Edmundo França

- Categoria Ciências Exatas e Tecnologia

Caos - Uma Introdução - Nelson Fiedler Ferrara e Carmen Cintra do Prado

Curso de Circuitos Elétricos vol. 1 e 2 - Luiz de Queiroz Orsini

O Sonho e a Técnica: A Arquitetura de Ferro no Brasil - Cacilda

Teixeira da Costa

- Categoria Ciências Humanas (exceto Letras)

A Aventura da Universidade - Cristovam Buarque

O Futurismo Paulista- Annateresa Fabris

Teatro do Sacramento - Alcir Pécora

- Categoria Ciências Naturais e Medicina

Cardiologia - Atualização e Reciclagem - Antonio P. Barreto e Amanda Sousa

Fundamentos Práticos de Taxonomia Zoológica - Nelson Papavero História Ecológica da Terra - Maria Léa Salgado Labouriau

- Categoria Contos / Crônicas / Novelas

Ah, É? - Dalton Trevisan

Arca sem Noé - História do Edifício Copan - Regina Rheda

O Museu Darbot e Outros Mistérios - Victor Giudice

- Categoria Didático

Convite à Filosofia - Marilena Chauí

História do Brasil - Boris Fausto

Letra Viva - Maria Setúbal, Beatriz Lomonaco e Isabel Brunsizian

- Categoria Economia, Administração e Negócios

Novo Dicionário de Economia - Paulo Sandroni

O Brasil que dá Certo - Setephen Charles Kanitz

Repensando as Pequenas e Médias Empresas - José Roberto

Saviani

- Categoria Estudos Literários (Ensaio)

Alquimistas e Químicos - José Atílio Vanin

Guerra e Paz - Ricardo Araújo 
Vinicius de Moraes - O poeta da Paixão - José Castello

A Bela e a Fera - Rui de Oliveira

- Categoria Ilustrações

A Bela e a Fera - Rui de Oliveira

A Bruxa Zelda e os Oitenta Docinhos - Eva Furnari

Cena de Rua - Ângela Lago

- Categoria Melhor Livro Infantil ou Juvenil

Carta Errante / Avó Atrapalhada / Menina Aniversariante - Mirna

Pinsky

Meninas da Praça da Alfândega - Sergio Capparelli

- Categoria Melhor Produção Editorial Livro Texto

Fani Brache - Fani Bracher, Resp: Marcos Veiga Pereira

O Brasil dos Viajantes vols. 1, 2 e 3 - Ana Moraes, Resp: Ronaldo

Graça Couto

Olhar Europeu - Boris Kossoy e Maria Carneiro, Resp: Maria Watanabe

- Categoria Poesia

A Sagração dos Ossos - Ivan Junqueira

As Horas de Katharina - Bruno Tolentino

Metamorfose - Paulo Leminski

- Categoria Reportagem

A Marcha para o Oeste - Orlando Villas Boas e Cláudio Villas Boas

Cidade Partida - Zuenir Ventura

Os Donos do Congresso - Elvis Bonassa, Fernando Rodrigues e

Gustavo Krieger

- Categoria Romance

A Descoberta das Américas pelos Turcos - Jorge Amado

Ana em Veneza - João Silvério Trevisan

Galantes Memórias e Admiráveis Aventuras do Virtuoso

Conselheiro Gomes, o Chalaça - José Roberto Torero

- Categoria Tradução

A Nova Heloísa - Fulvia Moretto

As Armas Secretas - Eric Nepomuceno

Rilke: Poesia - Coisa - Augusto de Campos 


\section{Prêmio 1996}

- Livro do Ano de Ficção

Quase Memória - Carlos Heitor Cony

- Livro do Ano de Não-Ficção

Estrela Solitária - Ruy Castro

- Categoria Capa

Ângulo de Repouso - Roberto de Vicq Cumptich

Clarice: Uma Vida que se Conta - Alfredo Ceschiatti

- Categoria Ciências Exatas, Tecnologia e Informática

Álgebra Linear - Elon Lages Lim

Eletrodinâmica de Weber - André K. T. Assis

Enciclopédia Agrícola Brasileira - Apresentação: Humberto de Campos

- Categoria Ciências Humanas

A Face e o Verso - Jurandir Freire Costa

Os Espirituais Franciscanos - Nachman Falbel

Rosa Luxemburgo - Isabel Maria Loureiro

Teorias da Globalização - Octávio Ianni

- Categoria Ciências Naturais e Medicina

Bioética - Orgs. C. Cohen e M. Segre

Lidando com Crianças - José Martins Filho

Velhos Novos Males Saúde Brasil - Orgs. Carlos Augusto Monteiro

- Categoria Contos

A Noite Escura e mais Eu - Lygia Fagundes Telles

O Buraco na Parede - Rubem Fonseca

Ovelhas Negras - Caio Fernando Abreu

- Categoria Didático de $1^{\circ}$ e $2^{\circ}$ Graus

A Palavra é sua, $5^{\mathbf{a}}$ a $8^{\mathbf{a}}$ séries - Celso P. Luft e Maria H. Corrêa

Dicionário Ilustrado - Douglas Tufano

Interações e Transformações: Elaborando Conceitos Sobre

Transformações

Químicas, vol. 1 - GEPEQ - Grupo de Pesquisa em Educação Química 
- Categoria Economia, Administração, Negócios e Direito As Partes \& o Todo - Eduardo G. Fonseca

Empresariado e Estado na Transição Brasileira - Sebastião C.

Velasco e Cruz

Made in Brazil - Ferraz, Kupper e Haguenauer

- Categoria Ensaio

A Contestação Necessária - Florestan Fernandes

Estrela Solitária - Ruy Castro

O Salão e a Selva - Maria Eugênia Boaventura

- Categoria Ilustração de Livro Infantil ou Juvenil

A Formiguinha e a Neve - Rogério Borges

A Risada do Saci - Helena Alexandrino

Tiro no Escuro - Rita Espechit

- Categoria Infantil ou Juvenil

A Cristaleira - Graziela Bozano Hetzel

Goeldi - Alberto Martins

Noções de Coisas - Darcy Ribeiro

- Categoria Poesia

Argumentos Invisíveis - Leonardo Fróes

Obra Poética - Renata Pallottini

Poemas da Estrangeira - Dora Ferreira da Silva

- Categoria Produção Editorial

Carta ao Pintor Moço - Virgínia S. Araújo

Momentos do Livro no Brasil - José Bantim Duarte

- Categoria Reportagem

As Noites das Grandes Fogueiras - Domingos Meirelles

Caso Escola Base - Alex Ribeiro

O Livro Negro da Corrupção - Coord. Modesto Carvalhosa

- Categoria Romance

Amor? - Ivan Ângelo

O Mistério do Leão Rampante - Rodrigo Lacerda

Quase Memória - Carlos Heitor Cony

- Categoria Tradução

A. P. Tchekhov - Sophia Angelides 
Ecce Homo - Paulo César Souza

Poemas: Giorgos Seféris - José Paulo Paes

\section{Prêmio 1998}

- Livro do Ano de Ficção

A Casa do Poeta Trágico - Carlos Heitor Cony

- Livro do Ano de Não-Ficção

Monteiro Lobato - Furacão na Botocúndia - Carmen Lúcia Azevedo, Márcia Camargos e Vladimir Sacchetta

- Categoria Capa

Arte Lúdica - Marcelo Mário

As Sementes do Tempo - Claudia Warrak

Os Últimos Combates - Mariana Fix e Pedro Arantes

- Categoria Ciências Exatas, Tecnologia e Informática

Introdução à Física Estatística - Silvio R. A. Salinas

Mecânica Clássica Moderna - Walter F. Wreszinski

O Romance Equações Algébricas - Gilberto G. Garbi

- Categoria Ciências Humanas

História das Mulheres no Brasil - Org. Mary Del Priore

História da Vida Privada no Brasil Vols. I e II - Laura M. Souza e Luiz F. Alencastro

Negócios e Ócios- Boris Fausto

- Categoria Ciências Naturais e Medicina

Doenças Infecciosas e Parasitas - Raimundo N. Queiroz de Leão

Fruteiras da Amazônia - Vários

Ornitologia Brasileira - Helmut Sick

- Categoria Contos e Crônicas

Menina a Caminho - Raduan Nassar

Nem Todo Canário é Belga - Flávio Moreira da Costa

Troços \& Destroço - João Silvério Trevisan

- Categoria Didático de $1^{\circ}$ e $2^{\circ}$ Graus

Aprendiz do Futuro - Gilberto Dimenstein

Coleção Tantas Palavras - vols.1 a 4 - Ana P. Laroca e M. Helena 
Passador

Ética e Cidadania - Coord. Silvio Gallo

- Categoria Economia, Administração, Negócios e Direito

A Energia do Brasil - Antonio Dias Leite

Poder e Dinheiro - Orgs. Maria C.Tavares e J. L. Fiori

Tecnologia Informação e Estratégia Empresarial - Org. Jacques

Marcovitch

- Categoria Ensaio e Biografia

A Dança do Universo - Marcelo Gleiser

Monteiro Lobato - Furacão na Botocúndia - Márcia Camargos, Carmen de Azevedo e Vladimir Sacchetta

Uma República de Leitores - Joaci Pereira Furtado

- Categoria Ilustração Infantil Ou Juvenil

A Menina, a Gaiola, Bicicleta; Céu de Passarinhos - Várias

Anjinho - Eva Furnari

Chapeuzinho Amarelo - Ziraldo Alves Pinto

- Categoria Infantil ou Juvenil

As Fatias do Mundo - Nilma Gonçalves Lacerda

Maria Martins - Katia Canton e Maria Tereza Louro

Minhas Memórias de Lobato - Luciana Sandroni

- Categoria Poesia

Ao Lado de Vera - Alberto da Costa e Silva

Galope do Tempo - Reynaldo Valinho Alvarez

O Mar de Permeio - Marly de Oliveira

- Categoria Produção Editorial

Coleção Nova Enciclopédia Barsa - Donaldson Garschagen

Doc. Autógrafos Brasileiro - Marcos da Veiga Pereira

Wessel: Os Segredos da Carne - Alexandre Dorea Ribeiro

- Categoria Reportagem

A Morte de P. C. Farias - George Sanguinetti

Os Estrangeiros do Trem $\mathbf{N}$ - Sérgio Vilas Boas

Terra - Sebastião Salgado

- Categoria Romance

A Casa do Poeta Trágico - Carlos Heitor Cony 
Lealdade - Márcio Souza

Um Crime Delicado - Sérgio Sant'Anna

- Categoria Tradução

Ascese - Os Salvadores de Deus - José Paulo Paes

Breviário de Estética e Aesthetica in Nuce - Rodolfo Ilari

Crônicas Italianas - Sebastião Uchôa Leite 


\section{PREMIAÇÕES NA FNLIJ}

Fonte: FNLIJ

Avesso ao endereço eletrônico: (http://www.fnlij.org.br/)

\begin{tabular}{|c|c|c|c|c|}
\hline \multicolumn{2}{|c|}{} & \multicolumn{4}{|c|}{1974} \\
\hline Categoria & Título & Escritor & Ilustrador & Editora \\
\hline Criança & $\begin{array}{c}\text { O rei de } \\
\text { quase tudo }\end{array}$ & $\begin{array}{c}\text { Eliardo } \\
\text { França }\end{array}$ & Eliardo França & $\begin{array}{c}\text { Orientação Cultural } \\
\text { atualmente, pela Mary } \\
\text { \& Eliardo França; Zit } \\
\text { Editora) }\end{array}$ \\
\hline
\end{tabular}

\begin{tabular}{|c|c|c|c|c|}
\hline Categoria & Título & Escritor & Ilustrador & Editora \\
\hline Criança & $\begin{array}{c}\text { O que os olhos não } \\
\text { vêem }\end{array}$ & Ruth Rocha & $\begin{array}{c}\text { José Carlos } \\
\text { de Brito }\end{array}$ & Salamandra \\
\hline Imagem & Coleção Peixe-vivo & Eva Furnari & Eva Furnari & Ática \\
\hline Imagem & Ida e volta & $\begin{array}{c}\text { Juarez } \\
\text { Machado }\end{array}$ & $\begin{array}{c}\text { Juarez } \\
\text { Machado }\end{array}$ & $\begin{array}{c}\text { Primor } \\
\text { (atualmente, } \\
\text { pela Editora } \\
\text { Agir) }\end{array}$ \\
\hline Jovem & De olho nas penas & $\begin{array}{c}\text { Ana Maria } \\
\text { Machado }\end{array}$ & $\begin{array}{c}\text { Gerson } \\
\text { Conforto }\end{array}$ & Salamandra \\
\hline
\end{tabular}

\begin{tabular}{|c|c|c|c|c|}
\hline Categoria & Título & $\begin{array}{c}\text { Escritor } \\
\text { Ilustrador }\end{array}$ & Editora \\
\hline Criança & Asa de papel & $\begin{array}{c}\text { Marcelo } \\
\text { Xavier }\end{array}$ & $\begin{array}{c}\text { Marcelo } \\
\text { Xavier }\end{array}$ & Formato \\
\hline $\begin{array}{c}\text { Escritor } \\
\text { Revelação }\end{array}$ & Lições de Girafa & Léo Cunha & $\begin{array}{c}\text { Vários } \\
\text { Autores }\end{array}$ & Miguilim \\
\hline $\begin{array}{c}\text { Escritor } \\
\text { Revelação }\end{array}$ & $\begin{array}{c}\text { O sabiá e a } \\
\text { girafa }\end{array}$ & Léo Cunha & Graça Lima & Nova Fronteira \\
\hline $\begin{array}{c}\text { Escritor } \\
\text { Revelação }\end{array}$ & $\begin{array}{c}\text { Pela estrada } \\
\text { afora }\end{array}$ & Léo Cunha & $\begin{array}{c}\text { Cláudia } \\
\text { Ferreira }\end{array}$ & Atual \\
\hline $\begin{array}{l}\text { Ilustrador } \\
\text { Revelação }\end{array}$ & $\begin{array}{c}\text { Os incríveis } \\
\text { seres } \\
\text { fantásticos }\end{array}$ & $\begin{array}{c}\text { Samir } \\
\text { Meserani }\end{array}$ & $\begin{array}{c}\text { Mariza Dias } \\
\text { da Costa }\end{array}$ & FTD \\
\hline
\end{tabular}




\begin{tabular}{|c|c|c|c|c|}
\hline Imagem & $\begin{array}{c}\text { O caminho do } \\
\text { caracol }\end{array}$ & $\begin{array}{c}\text { Helena } \\
\text { Alexandrino }\end{array}$ & $\begin{array}{c}\text { Helena } \\
\text { Alexandrino }\end{array}$ & Studio Nobel \\
\hline Imagem & O gato viriato & Roger Mello & Roger Mello & Ediouro \\
\hline Informativo & $\begin{array}{l}\text { A terra é sua. E } \\
\text { cuide dela! }\end{array}$ & $\begin{array}{l}\text { Josep Rosell. } \\
\text { Olga de Sá } \\
\text { (tradução) }\end{array}$ & $\begin{array}{l}\text { Xan López } \\
\text { Dominguez }\end{array}$ & Santuário \\
\hline Jovem & $\begin{array}{c}\text { Ana } Z \text {, aonde } \\
\text { vai você? }\end{array}$ & $\begin{array}{c}\text { Marina } \\
\text { Colasanti }\end{array}$ & $\begin{array}{c}\text { Marina } \\
\text { Colasanti }\end{array}$ & Ática \\
\hline Jovem & $\begin{array}{c}\text { Te dou a lua } \\
\text { amanhã... } \\
\text { biofantasia de } \\
\text { Mário de } \\
\text { Andrade }\end{array}$ & $\begin{array}{c}\text { Jorge Miguel } \\
\text { Marinho }\end{array}$ & $\begin{array}{l}\text { Saulo } \\
\text { Garroux } \\
\text { (projeto } \\
\text { gráfico) }\end{array}$ & $\begin{array}{c}\text { FTD } \\
\text { (atualmente, } \\
\text { pela Editora } \\
\text { Ática) }\end{array}$ \\
\hline Poesia & Lé com cré & $\begin{array}{c}\text { José Paulo } \\
\text { Paes }\end{array}$ & Alcy & Ática \\
\hline $\begin{array}{l}\text { Projeto } \\
\text { Editorial }\end{array}$ & $\begin{array}{c}\text { Coleção Folclore } \\
\text { de casa }\end{array}$ & Angela Lago & Angela Lago & RHJ \\
\hline $\begin{array}{c}\text { Tradução } \\
\text { Criança }\end{array}$ & $\begin{array}{l}\text { A cortina da tia } \\
\text { Bá }\end{array}$ & $\begin{array}{c}\text { Virgínia } \\
\text { Woolf. Ruth } \\
\text { Rocha } \\
\text { (tradução) }\end{array}$ & Julie Vivas & Ática \\
\hline
\end{tabular}

\begin{tabular}{|c|c|c|c|c|}
\hline \multicolumn{5}{|c|}{1994} \\
\hline Categoria & Título & Escritor & Ilustrador & Editora \\
\hline Criança & $\begin{array}{l}\text { Coleção Assim é } \\
\text { se lhe parece }\end{array}$ & $\begin{array}{c}\text { Angela } \\
\text { Carneiro, Lia } \\
\text { Neiva, Sylvia } \\
\text { Orthof }\end{array}$ & $\begin{array}{l}\text { Roger Mello, } \\
\text { Mariana } \\
\text { Massarani, } \\
\text { Elisabeth } \\
\text { Teixeira }\end{array}$ & Ediouro \\
\hline $\begin{array}{c}\text { Escritor } \\
\text { Revelação }\end{array}$ & $\begin{array}{c}\text { Ver de ver meu } \\
\text { pai }\end{array}$ & Celso Sisto & Roger Mello & Nova Fronteira \\
\hline $\begin{array}{l}\text { Ilustrador } \\
\text { Revelação }\end{array}$ & $\begin{array}{l}\text { Não houve } \\
\text { premiação }\end{array}$ & & & \\
\hline Imagem & A bela e a fera & Rui de Oliveira & $\begin{array}{l}\text { Rui de } \\
\text { Oliveira }\end{array}$ & FTD \\
\hline \begin{tabular}{|c|} 
Imagem \\
"Hors- \\
Concours"
\end{tabular} & Cena de rua & Angela Lago & Angela Lago & RHJ \\
\hline Informativo & $\begin{array}{c}\text { Coleção Alecrim } \\
\text { dourado }\end{array}$ & $\begin{array}{c}\text { Geruza Helena } \\
\text { Borges }\end{array}$ & $\begin{array}{l}\text { Geruza } \\
\text { Helena } \\
\text { Borges }\end{array}$ & Mazza \\
\hline Jovem & Atentado & $\begin{array}{c}\text { Sonia } \\
\text { Rodrigues } \\
\text { Mota }\end{array}$ & $\begin{array}{l}\text { Wilson } \\
\text { Cotrim }\end{array}$ & Ediouro \\
\hline $\begin{array}{c}\text { Melhor } \\
\text { Ilustração }\end{array}$ & $\begin{array}{l}\text { O macaco e a } \\
\text { boneca de cera }\end{array}$ & $\begin{array}{c}\text { Sonia } \\
\text { Junqueira }\end{array}$ & Roger Mello & Atual \\
\hline
\end{tabular}




\begin{tabular}{|c|c|c|c|c|}
\hline Poesia & $\begin{array}{l}\text { O velho que } \\
\text { trazia a noite }\end{array}$ & $\begin{array}{l}\text { Sérgio } \\
\text { Caparelli }\end{array}$ & $\begin{array}{l}\text { Cecília } \\
\text { Iwashita }\end{array}$ & $\begin{array}{c}\text { Kuarup } \\
\text { (atualmente, } \\
\text { pela Editora } \\
\text { Global) }\end{array}$ \\
\hline $\begin{array}{l}\text { Projeto } \\
\text { Editorial }\end{array}$ & $\begin{array}{l}\text { Coleção Assim é } \\
\text { se lhe parece }\end{array}$ & $\begin{array}{c}\text { Angela } \\
\text { Carneiro, Lia } \\
\text { Neiva, Sylvia } \\
\text { Orthof }\end{array}$ & $\begin{array}{l}\text { Roger Mello, } \\
\text { Mariana } \\
\text { Massarani, } \\
\text { Elisabeth } \\
\text { Teixeira }\end{array}$ & Ediouro \\
\hline $\begin{array}{l}\text { Tradução } \\
\text { Criança }\end{array}$ & A bruxa Salomé & $\begin{array}{l}\text { Audrey Wood. } \\
\text { Gisela Maria } \\
\text { Padovan } \\
\text { (tradução) }\end{array}$ & Don Wood & Ática \\
\hline $\begin{array}{c}\text { Tradução } \\
\text { Informativo }\end{array}$ & $\begin{array}{c}\text { Coleção As } \\
\text { origens do saber } \\
\text { (A criação da } \\
\text { pintura; O céu e } \\
\text { seus mistérios; } \\
\text { O fogo, amigo } \\
\text { ou inimigo?; A } \\
\text { música dos } \\
\text { instrumentos) }\end{array}$ & $\begin{array}{c}\text { Pierre } \\
\text { Marchand } \\
\text { (coordenação). } \\
\text { Vários } \\
\text { tradutores }\end{array}$ & Anne & Melhoramentos \\
\hline $\begin{array}{l}\text { Tradução } \\
\text { Jovem }\end{array}$ & $\begin{array}{l}\text { Kamô e a idéia } \\
\text { do século }\end{array}$ & $\begin{array}{c}\text { Daniel Pennac. } \\
\text { Dau Bastos } \\
\text { (tradução) }\end{array}$ & $\begin{array}{l}\text { Jean- } \\
\text { Philippe } \\
\text { Chabot }\end{array}$ & Salamandra \\
\hline
\end{tabular}




\section{LISTA DE ILUSTRAÇÕES}




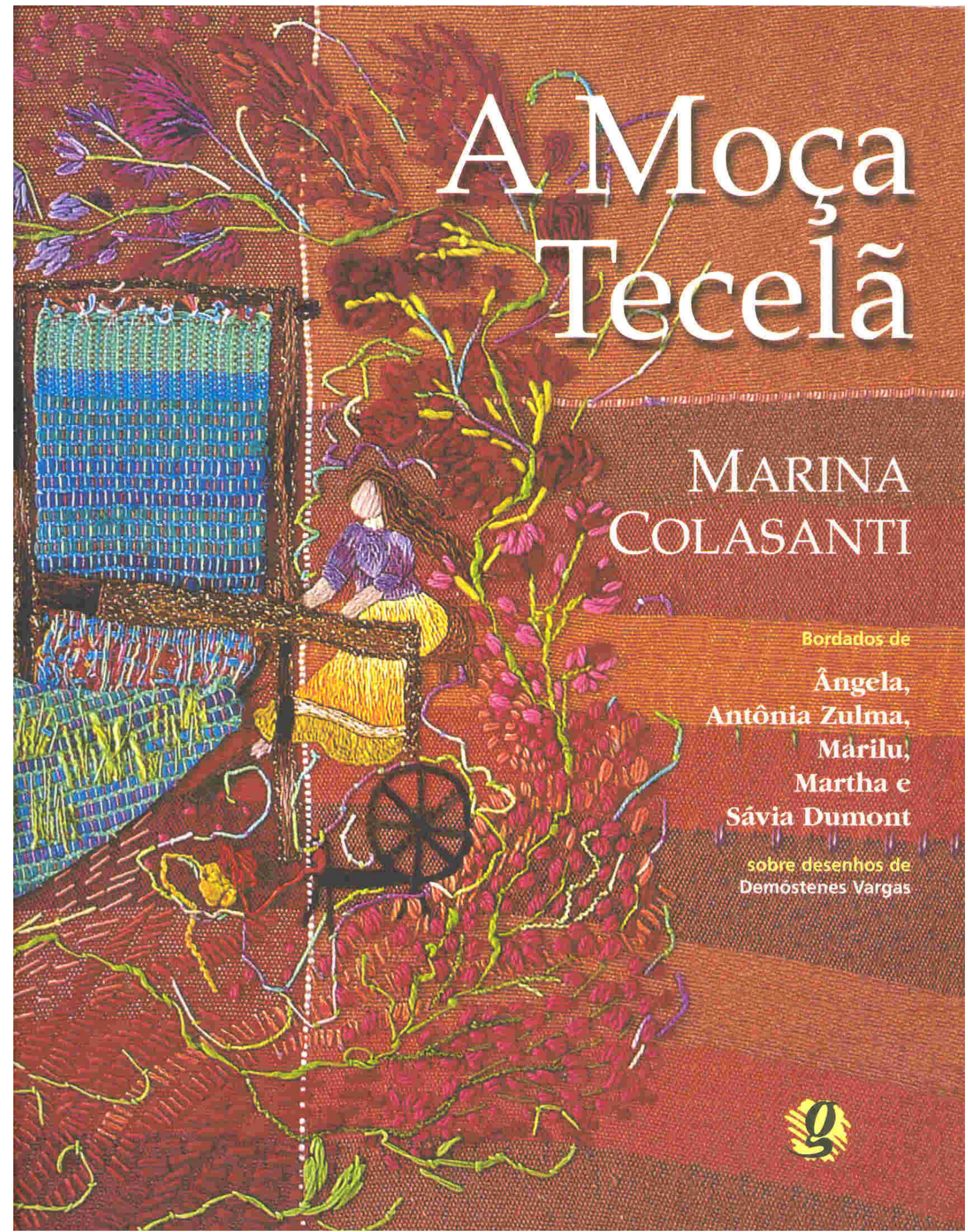




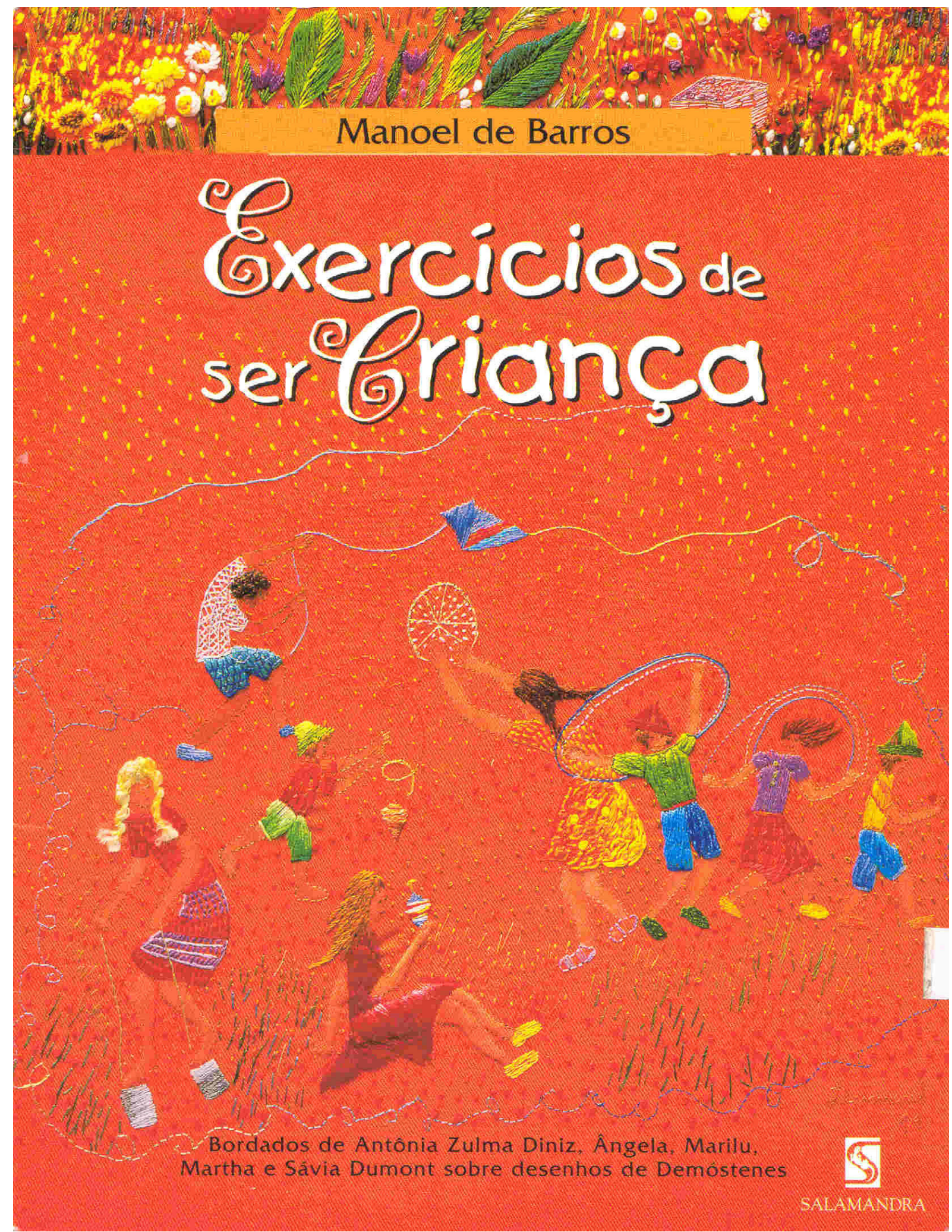




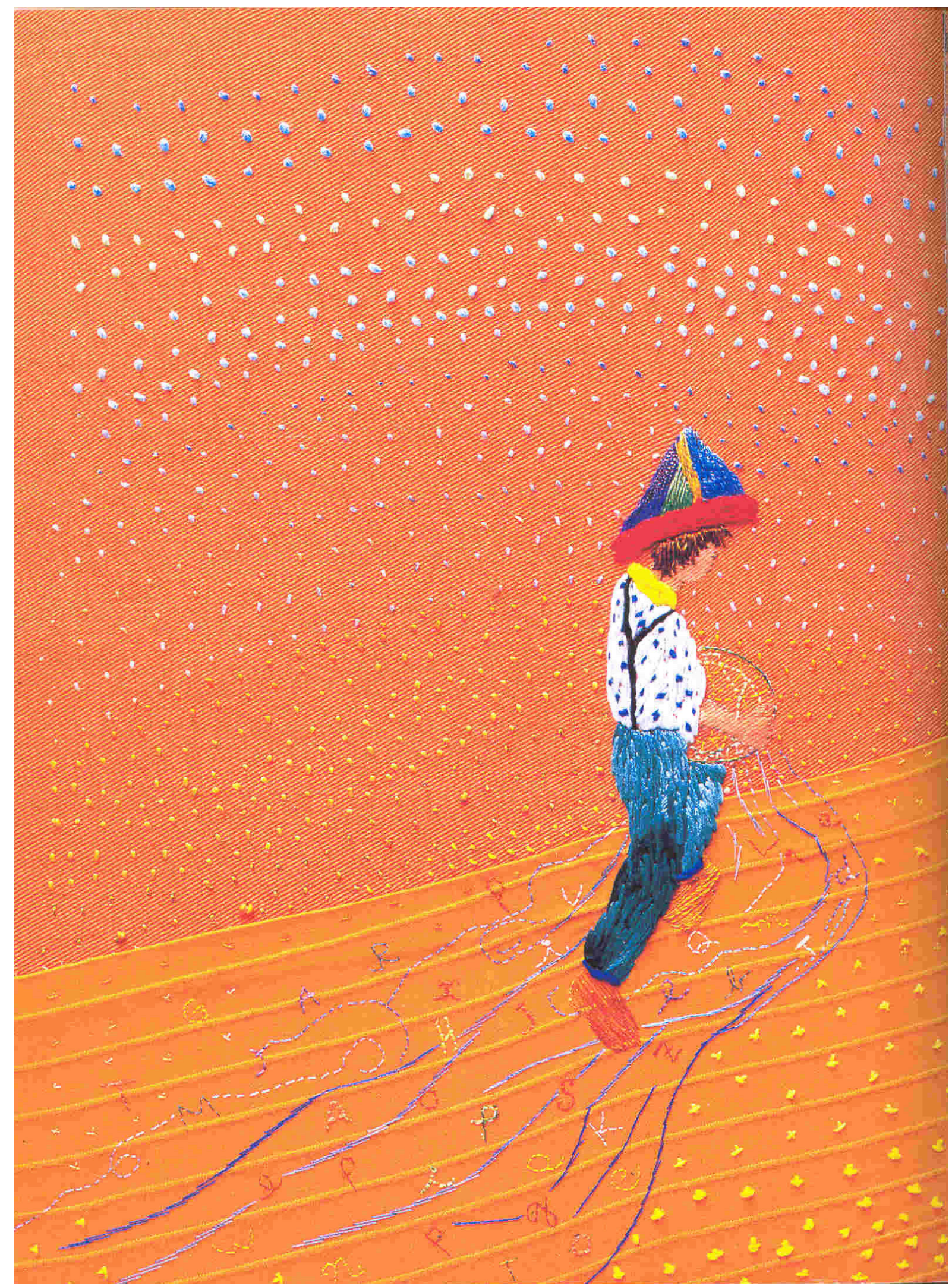


184

(6) menilies ale cerrregerva éght his penteira 


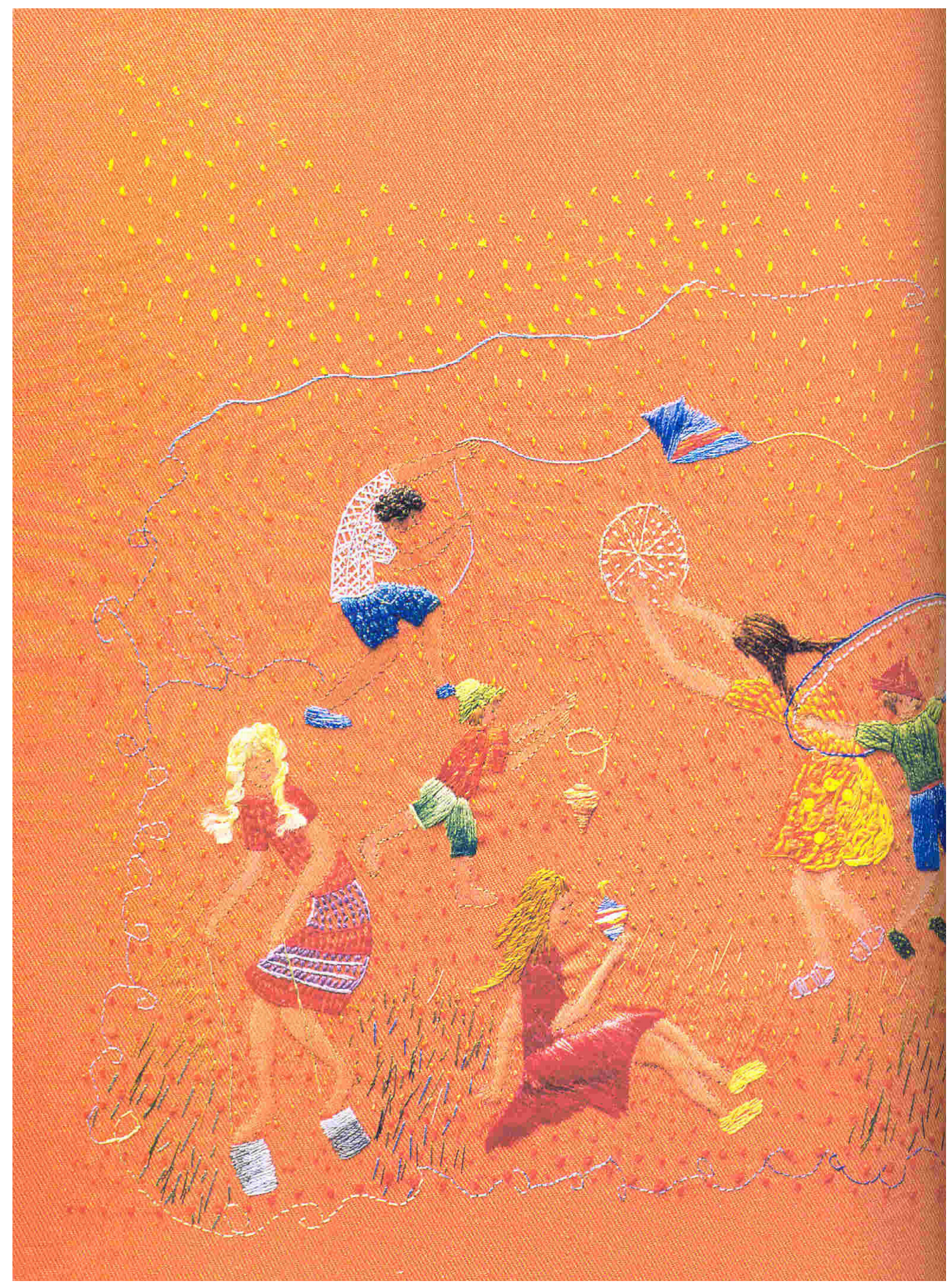


186

Você vai encher os vazios com as suas

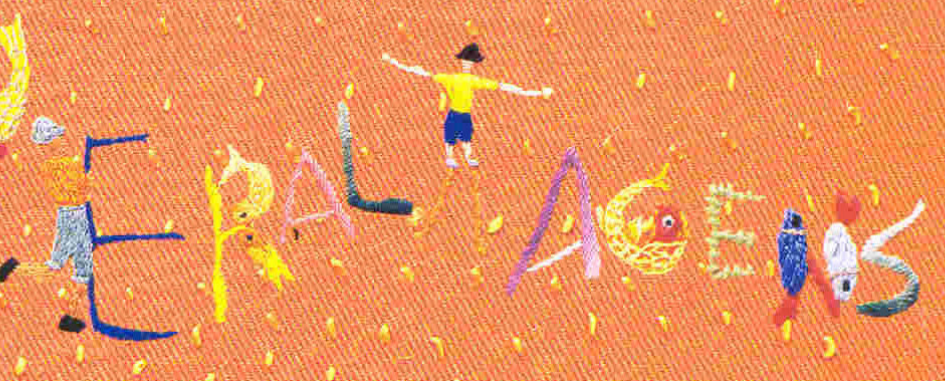

E algumas pessoas vão te amar por seus despropósitos. 


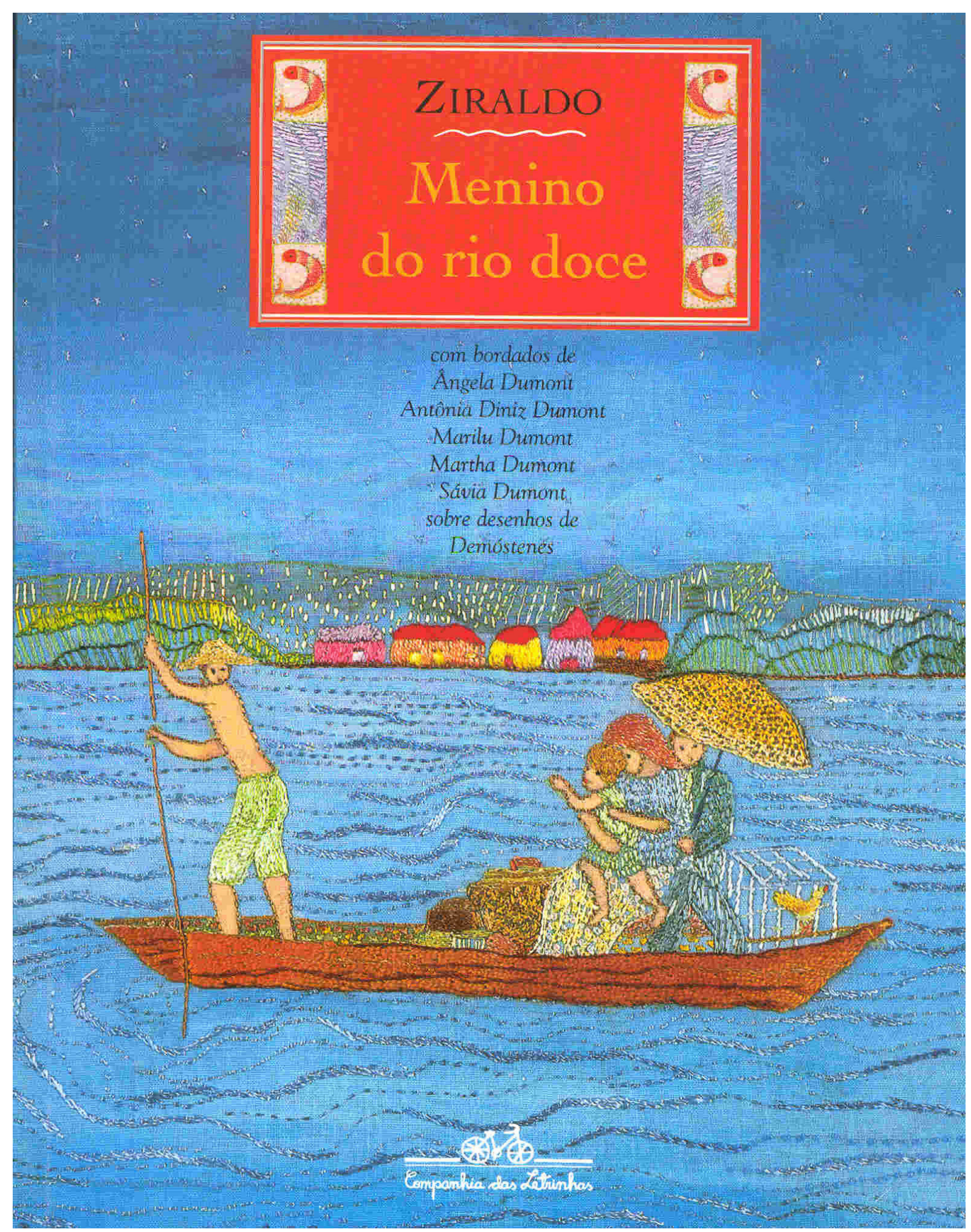



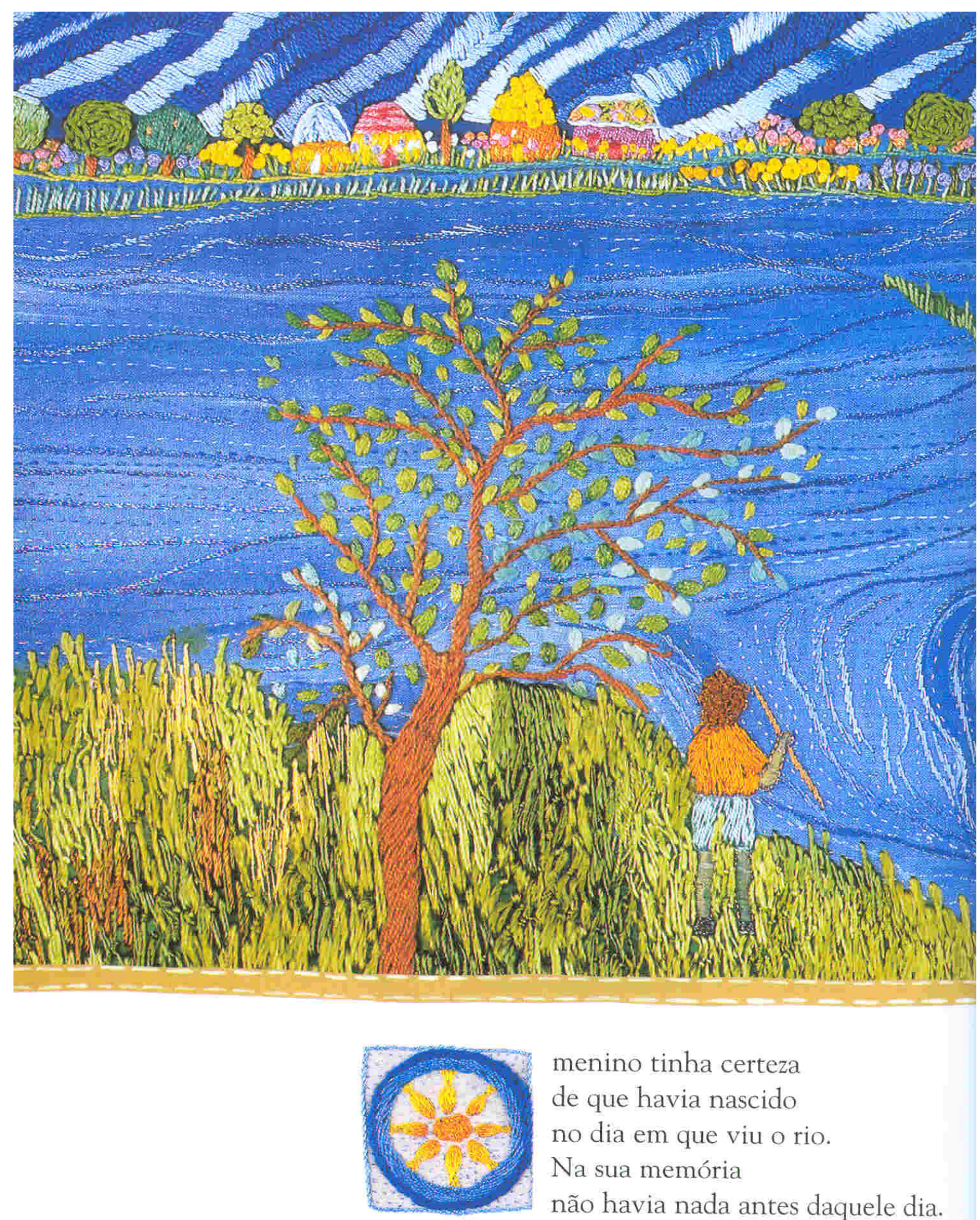

menino tinha certeza

de que havia nascido

no dia em que viu o rio.

Na sua memória

não havia nada antes daquele dia. 


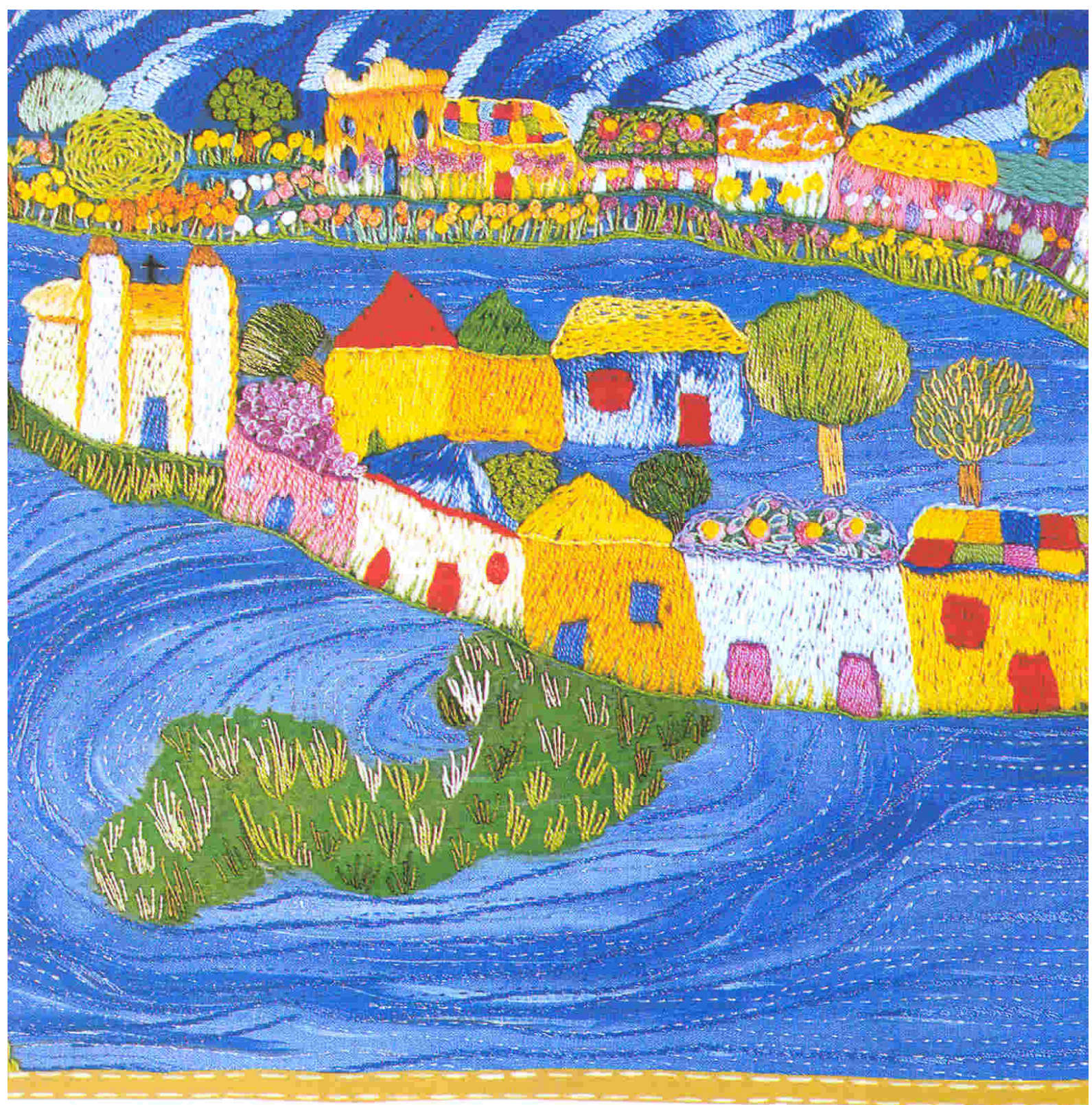

O menino amou o rio pois acreditou que o rio havia também nascido no dia em que ele o viu.

O menino olhava o rio: o rio era seu irmão. 


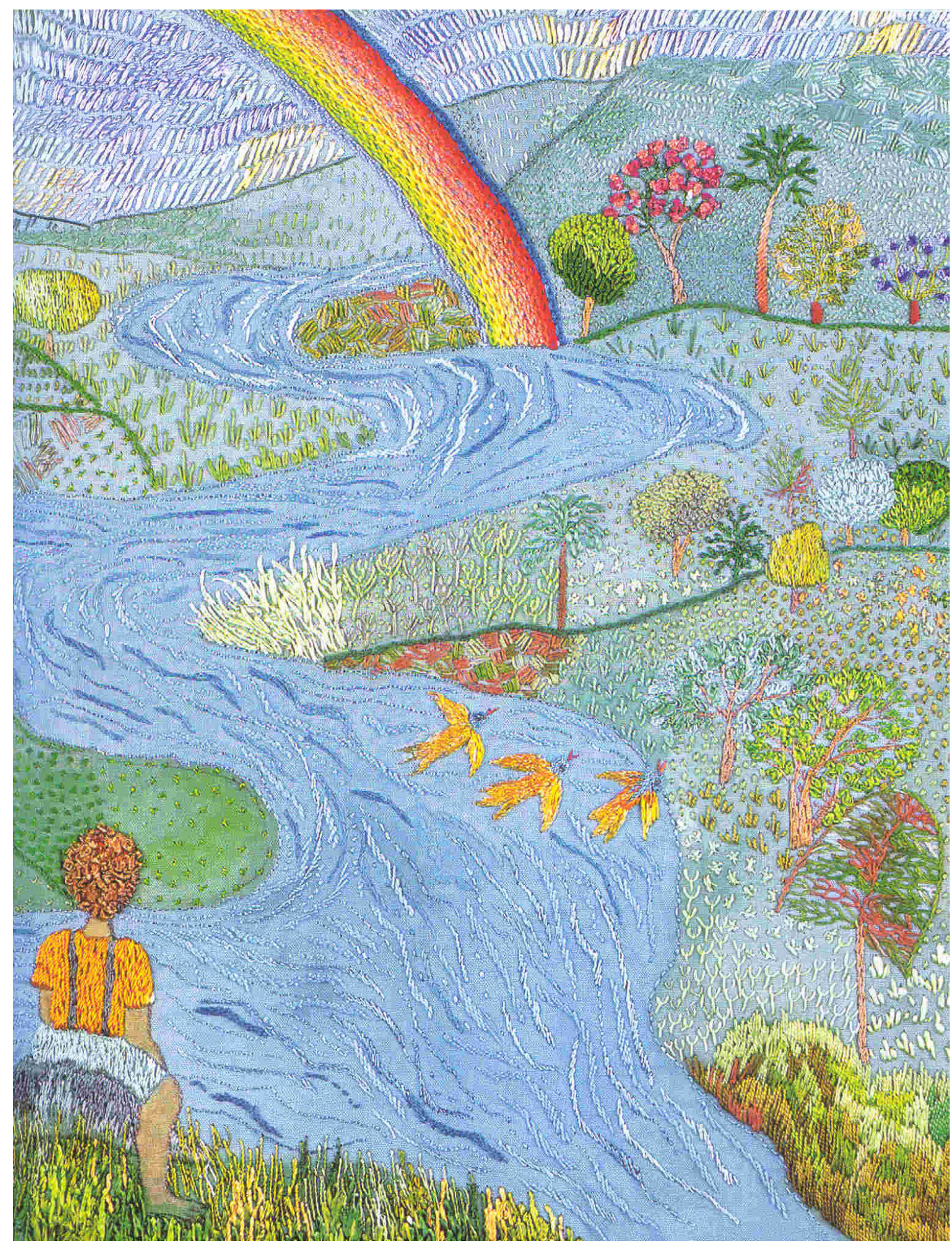




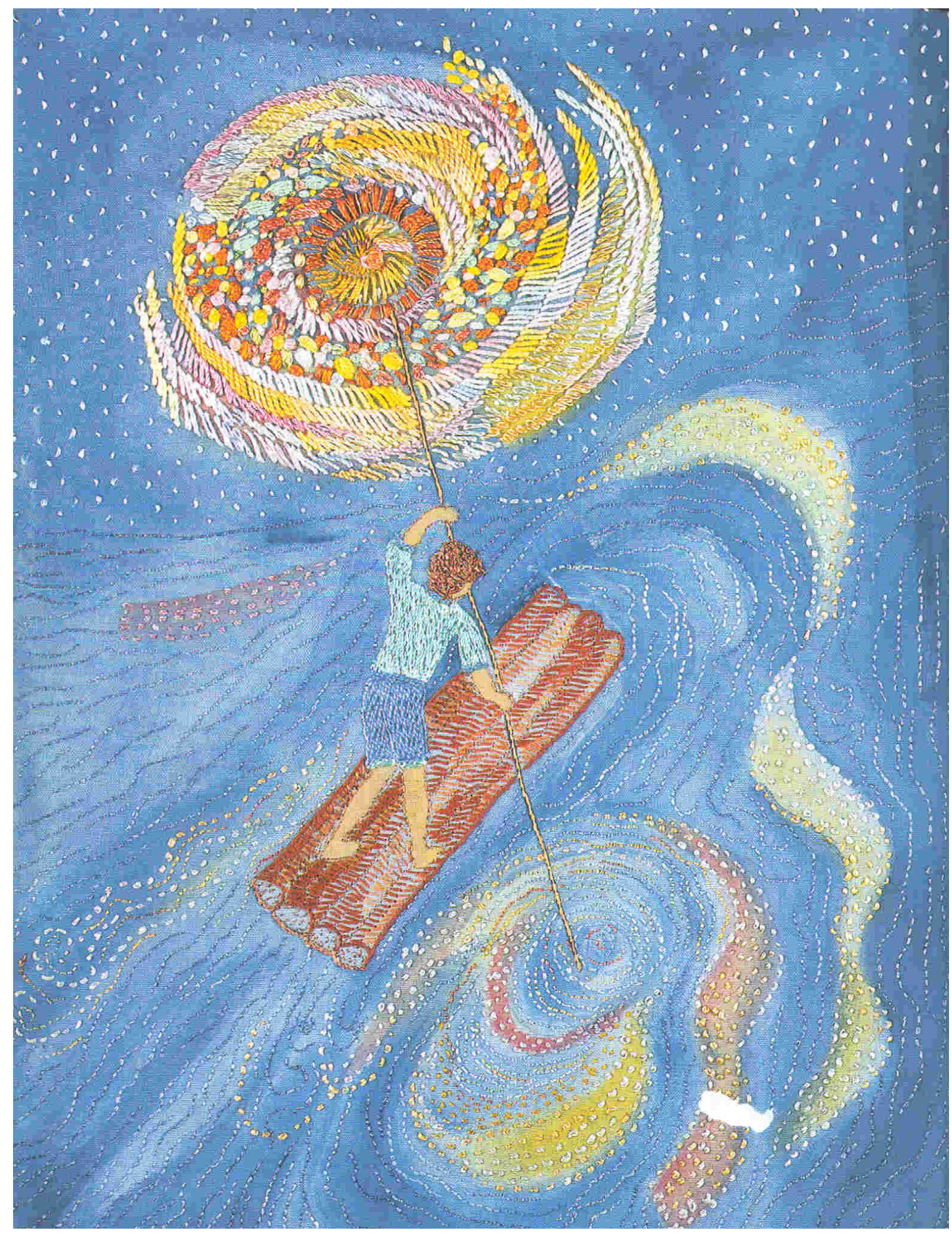




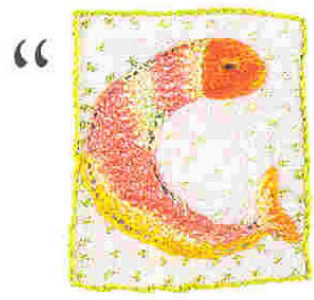

uidado com a Cobra-Grande que na noite escura vai descer o rio pra te devorar."

O menino escutava as histórias do rio que não eram as histórias do rio (não era o rio que contava).

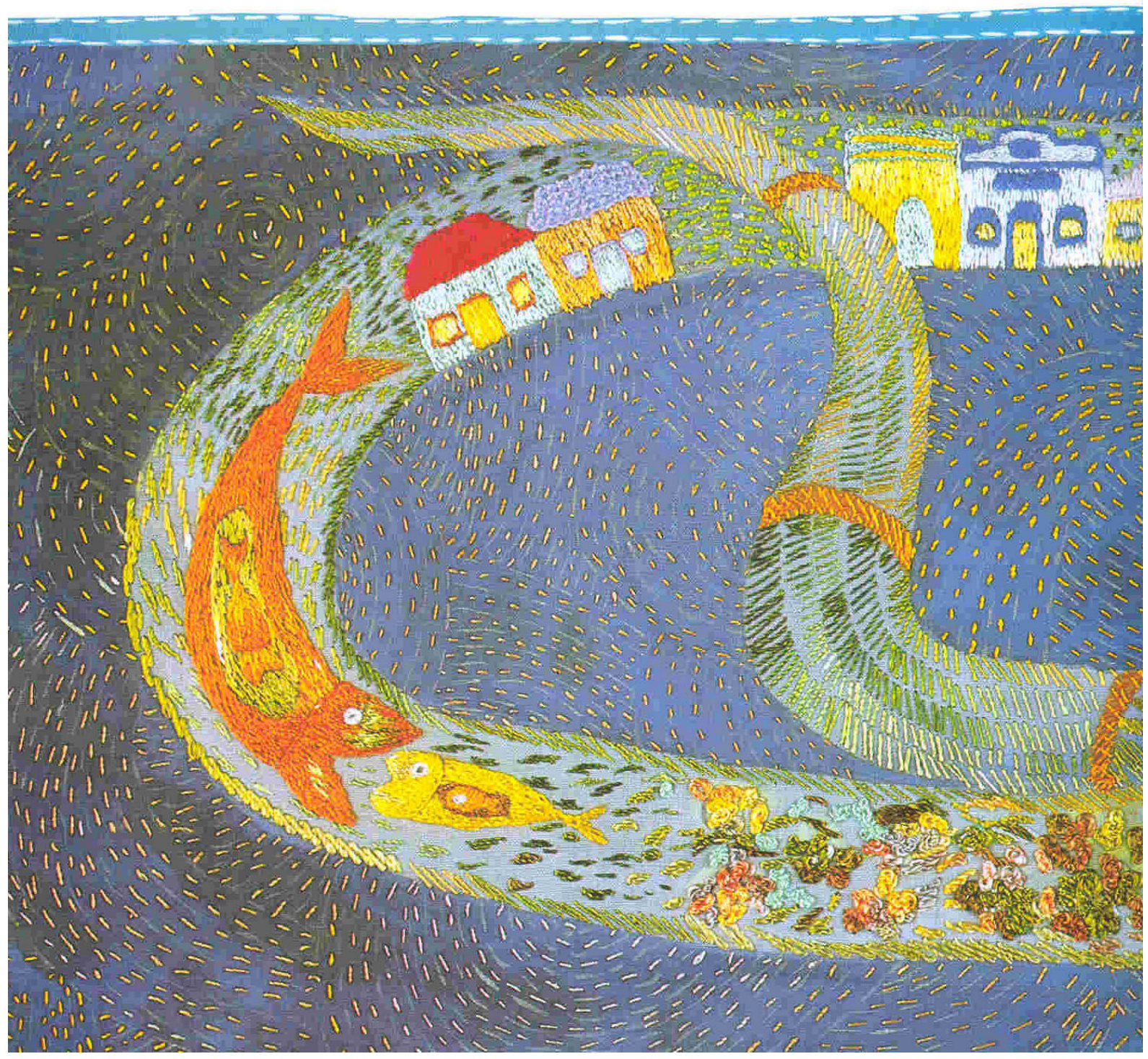


É por isso que o menino

não temia a serpente

que - contavam - morava lá

sob as águas do rio

e que, em noite negra,

o rio desceria

com seus olhos de fogo

— emiboitatá -

para devorar a Terra.

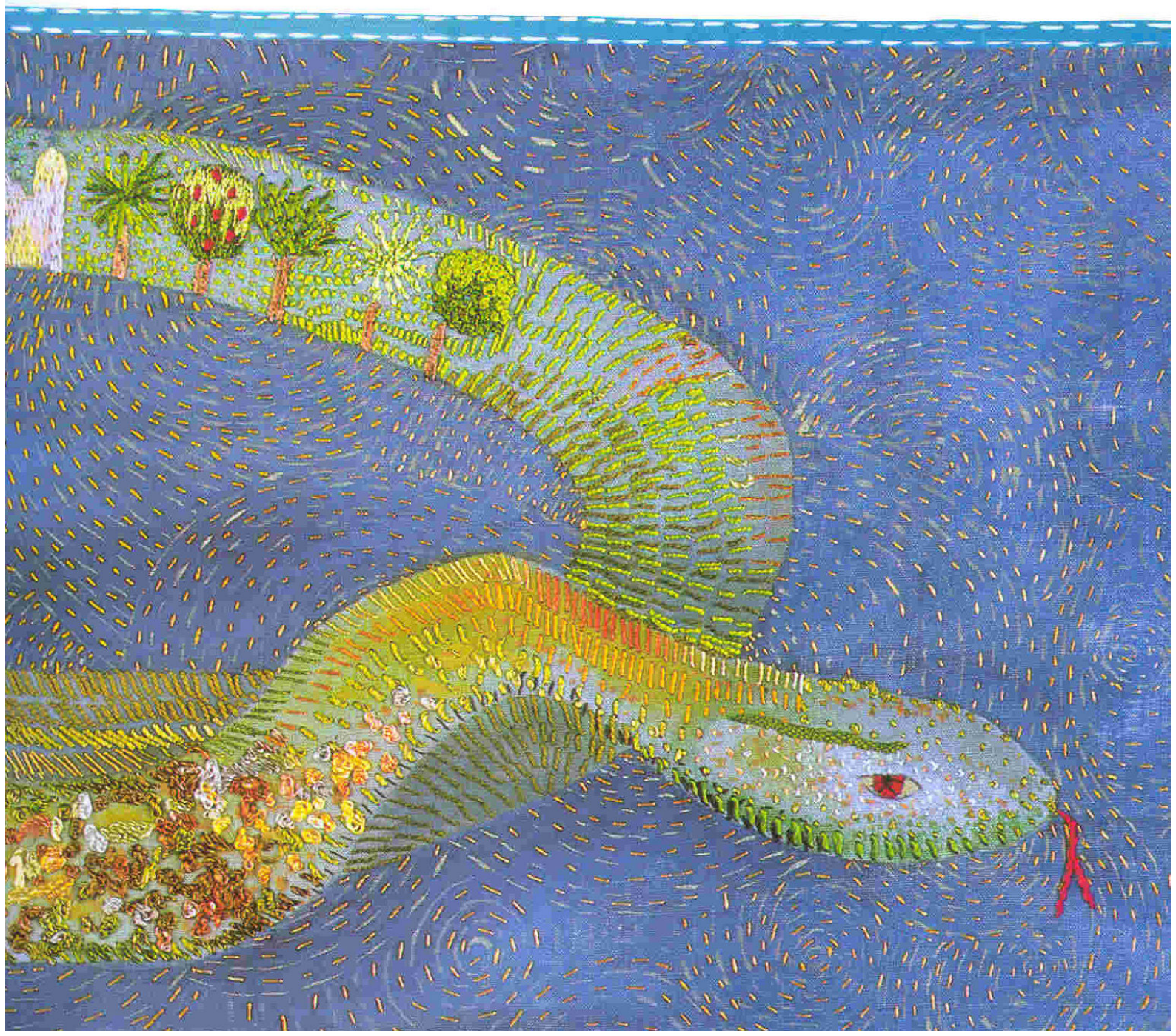




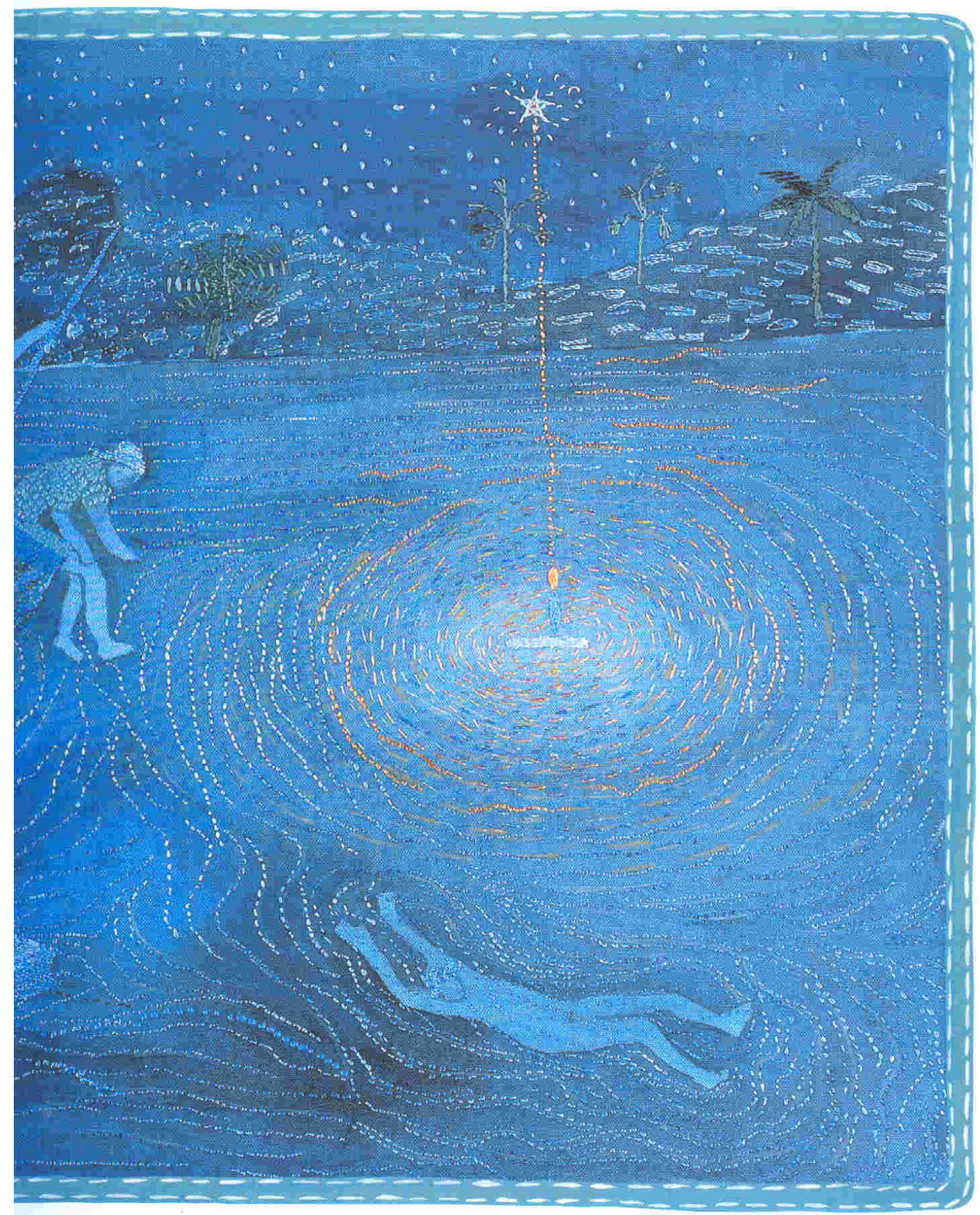




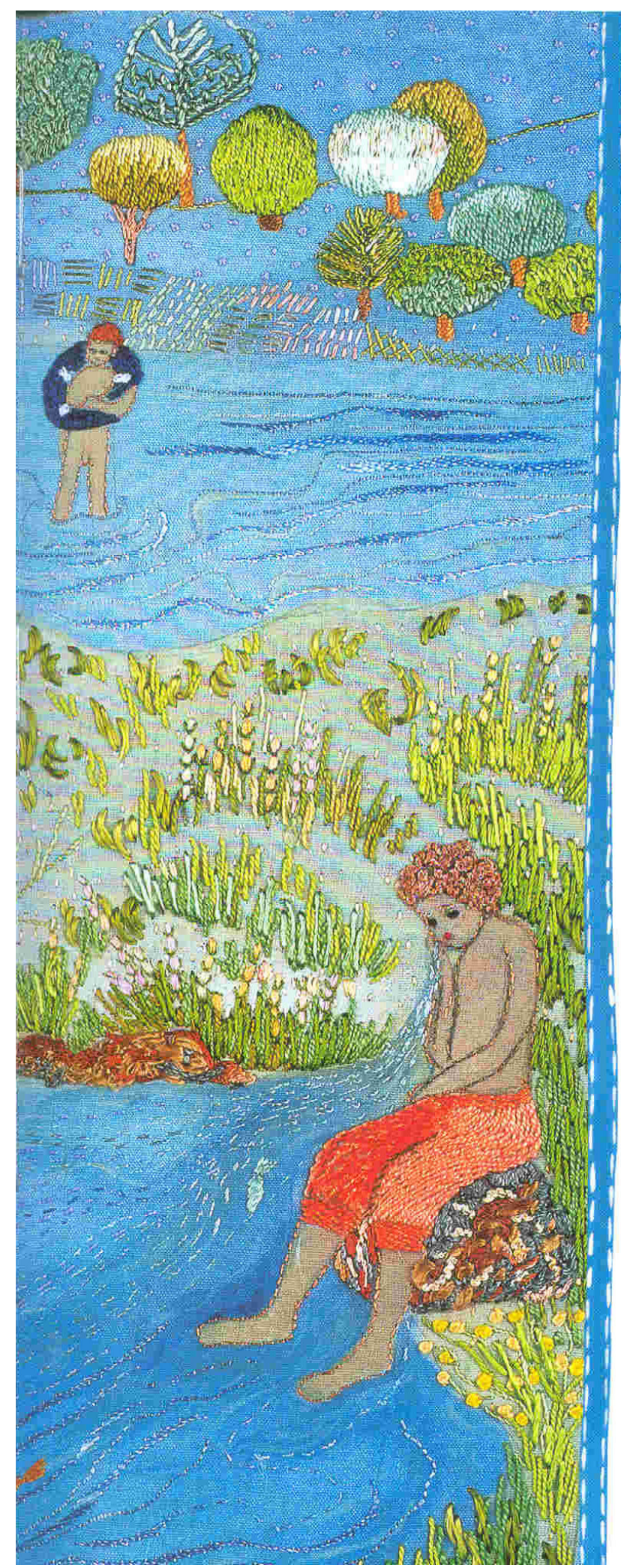

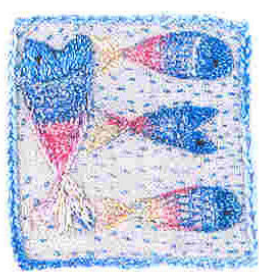

com o seu amigo morto nas águas do rio-irmão

o menino aprendeu que assim vivem os rios. E o menino chorou ${ }^{\circ}$ um rio de lágrimas, alimento do rio que vai passando. Como tudo vai passar.

menino brincava no rio, o menino brincava com o rio como brincam os moleques parceiros do mesmo tempo, pois que o rio tem a idade de quem brinca, vive ou morre no rio que, passando sob a ponte, é o tempo feito de água.

Vai indo o tempo, vai indo... vem o rio, o rio vai e o menino tem que ir. Cada um passa a seu modo. 


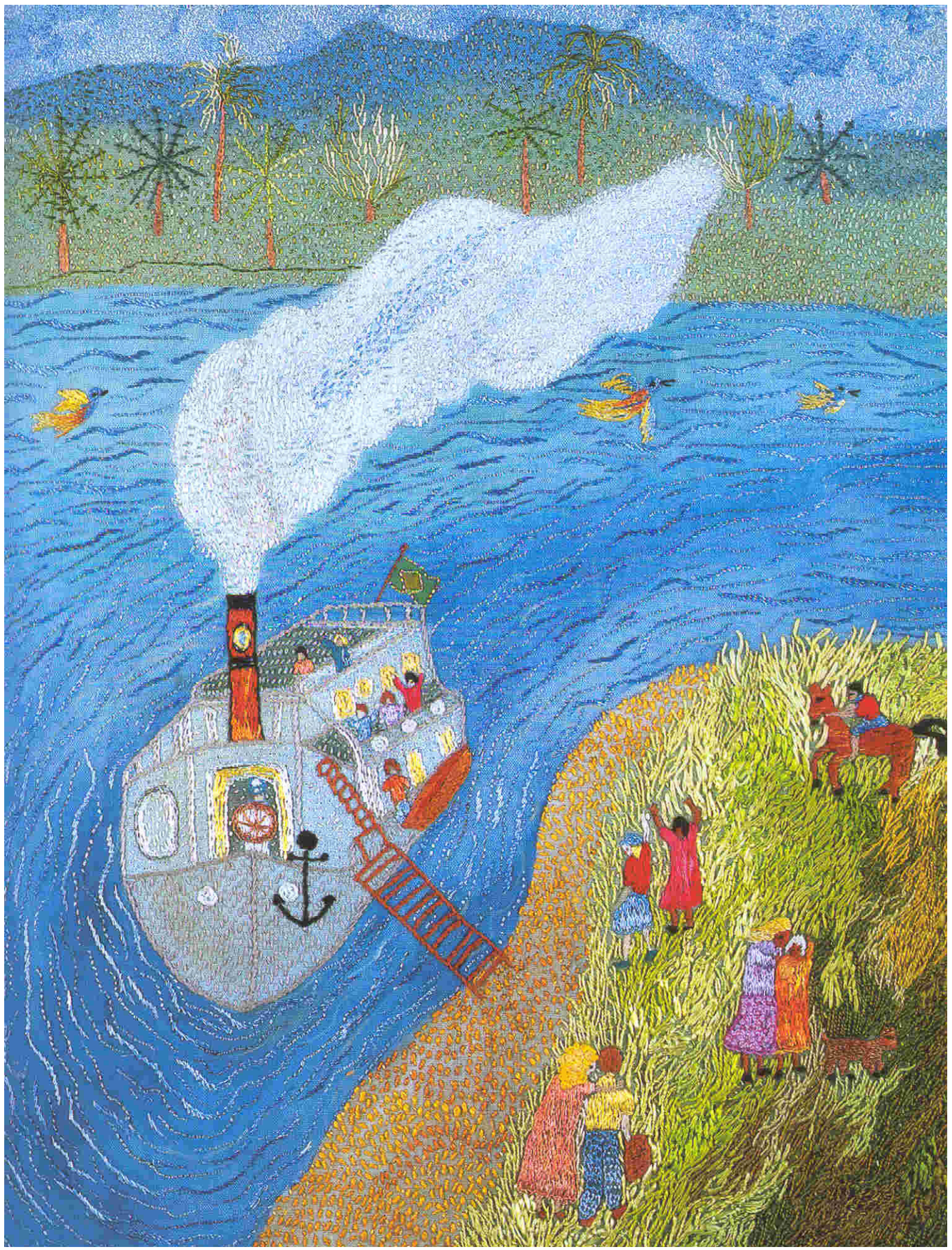




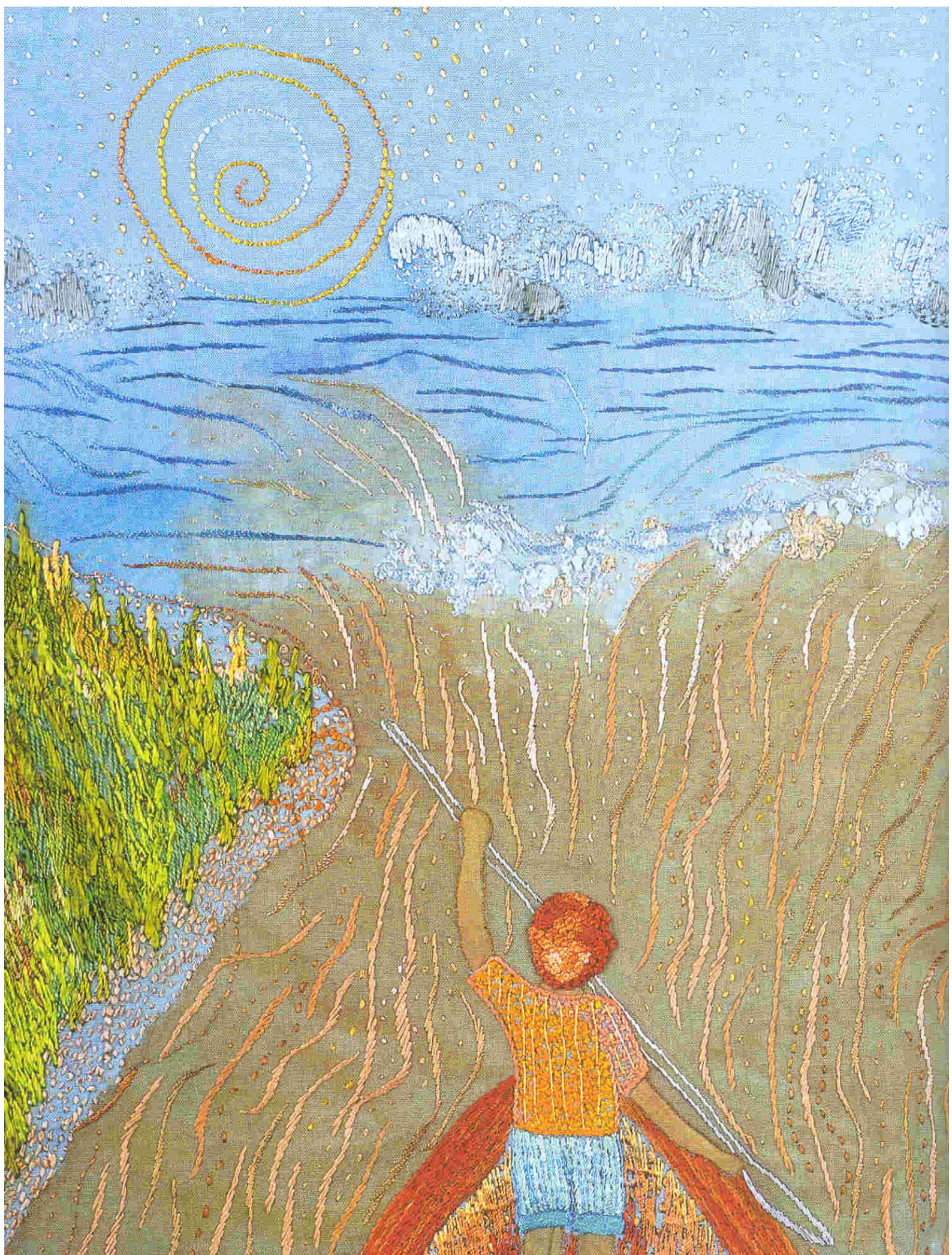




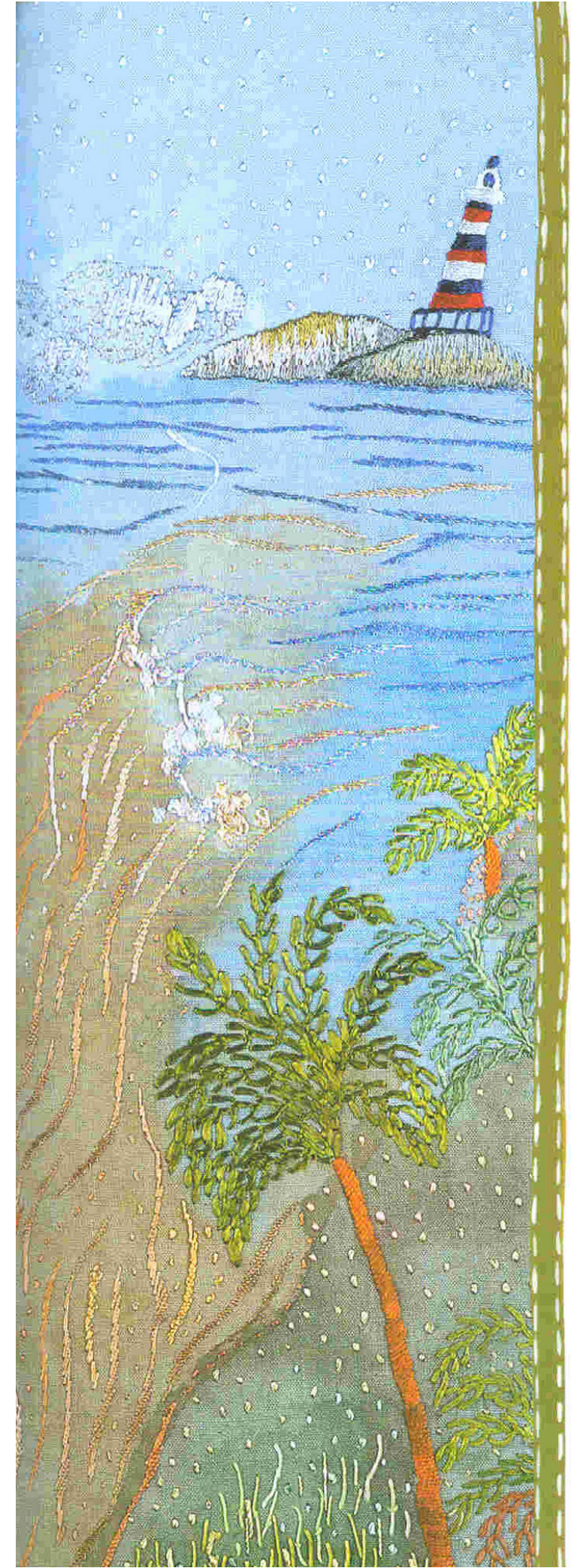

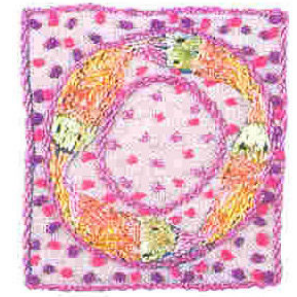

rio nasce - doce na gorda barriga da montanha e vai morrer

na praia (do lado de cá). Todo dia o rio nasce, todo dia o rio morre, todo dia o rio parte, chega o rio, todo dia, ao seu destino de sal.

"Vem comigo ao meu destino!", diz o rio ao seu menino que, agora, quase homem parte-se para partir.

"O mar é o meu começo", adivinhou o menino (ou o rio lhe ensinou).

E o rio repete: "Vem!".

E dizendo isso o rio se desmancha no azul da água salgada do mar. Onde a história do homem que veio vindo com o rio - menino feito de água agora vai começar... 


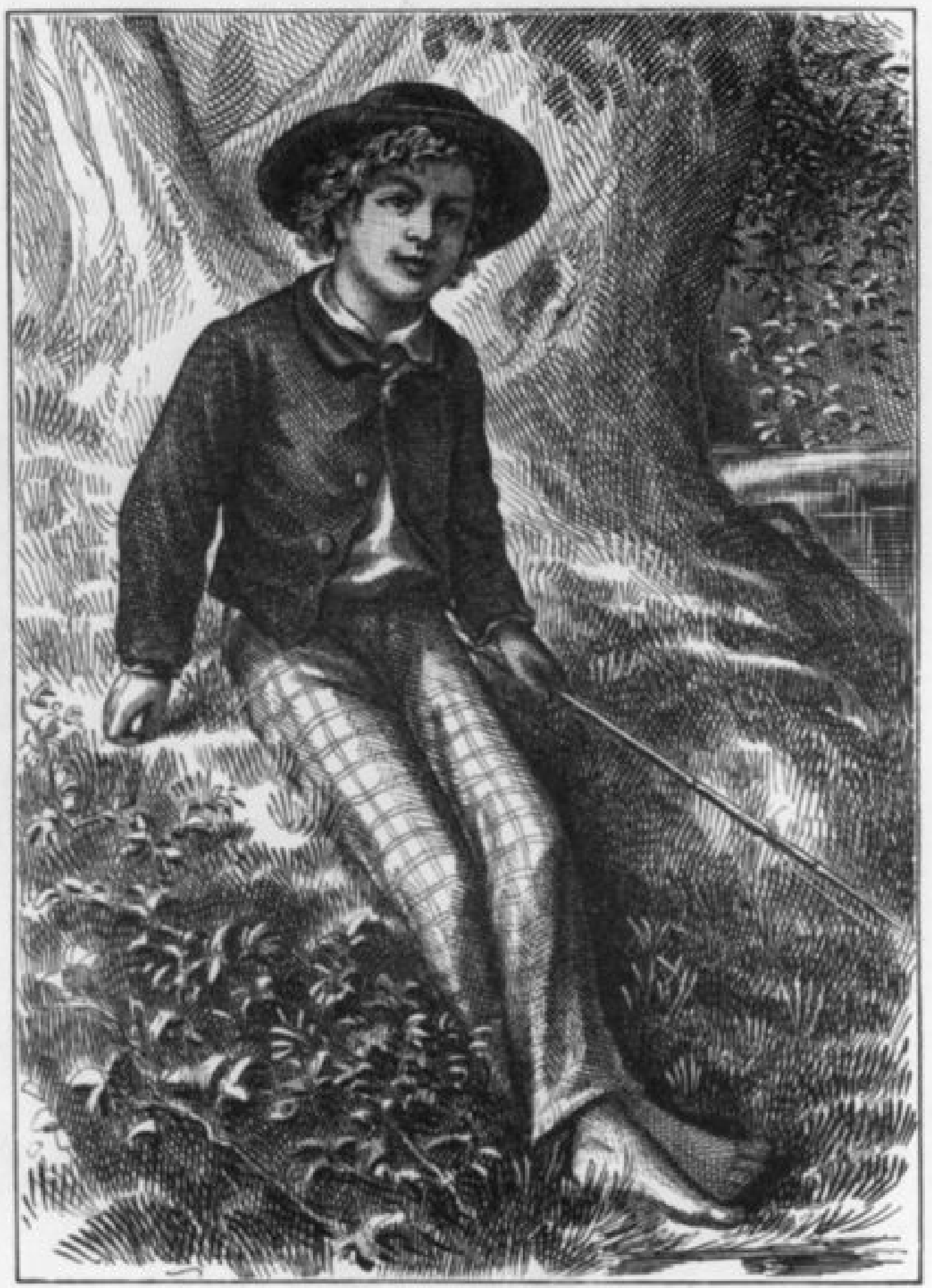




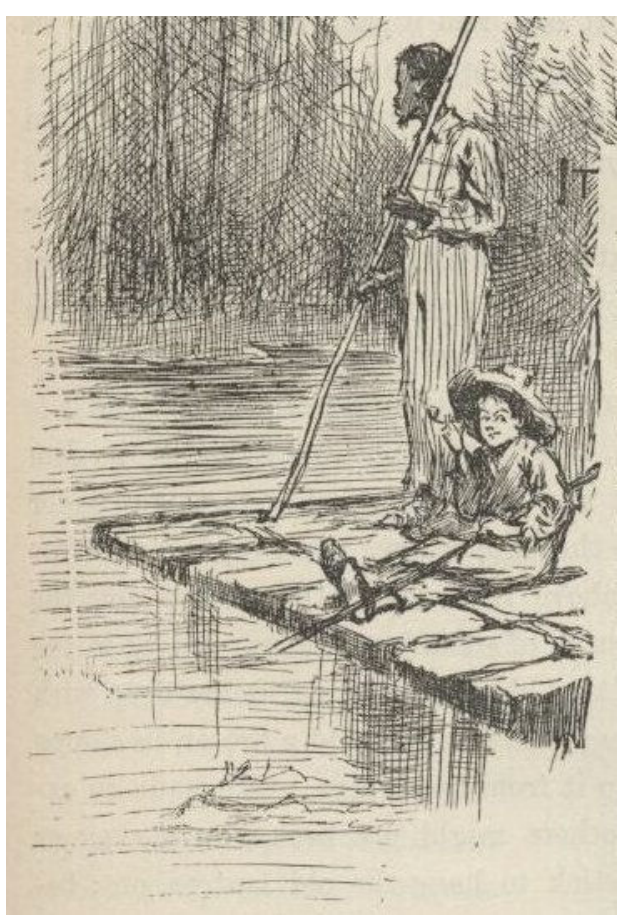


town. Two or three glimmering lighs showed where it lay poctally sleepIng, byond the wage rast swepp of star-gemened water, unconscious of the tremendous event thut was happening. The Dlack Aveager stood sill with folded arms, "looking his last" upoe the seese of his tormer joys and his later

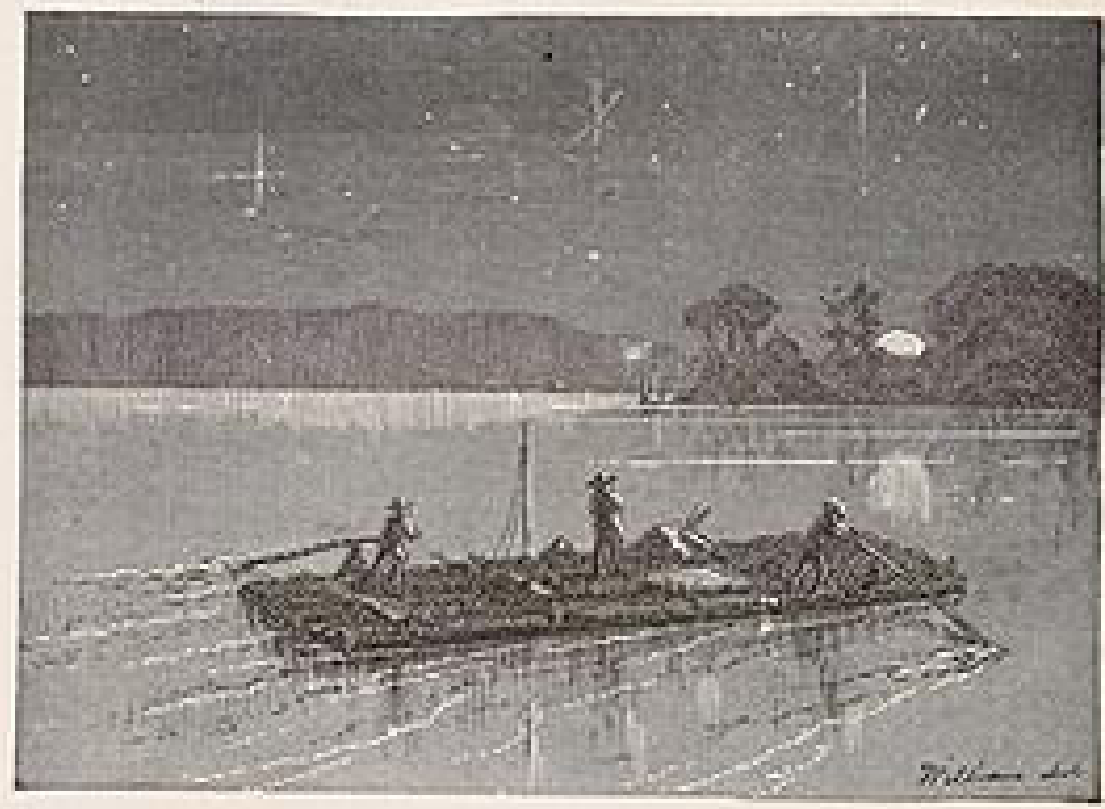

ex Mal: mine sial har.

suterings and whing "she" ould so bin now, abroad on the wild vei, faing peril and tath whth dauntles hest, going to his doon with a grim smile on his lips, It was bat a saall strio on bis imagination to remove Jackton's Island begond groshot of the vilhige, and $\%$ he "looked his last" with a broken and satified heart. The ohef pirates were looking their last, too; and they all looked so long that thty came near leting the current drif them out of the fango of the llland. Bat qhes diroovered tho dinger in time, and mate shift to akert it. About two oclock in the morning the raft grounded on the bar two hundred yurds above the head of the IMland, and they waded back nud forth untll they bad lasded their freight. Part of the lintle raft's 


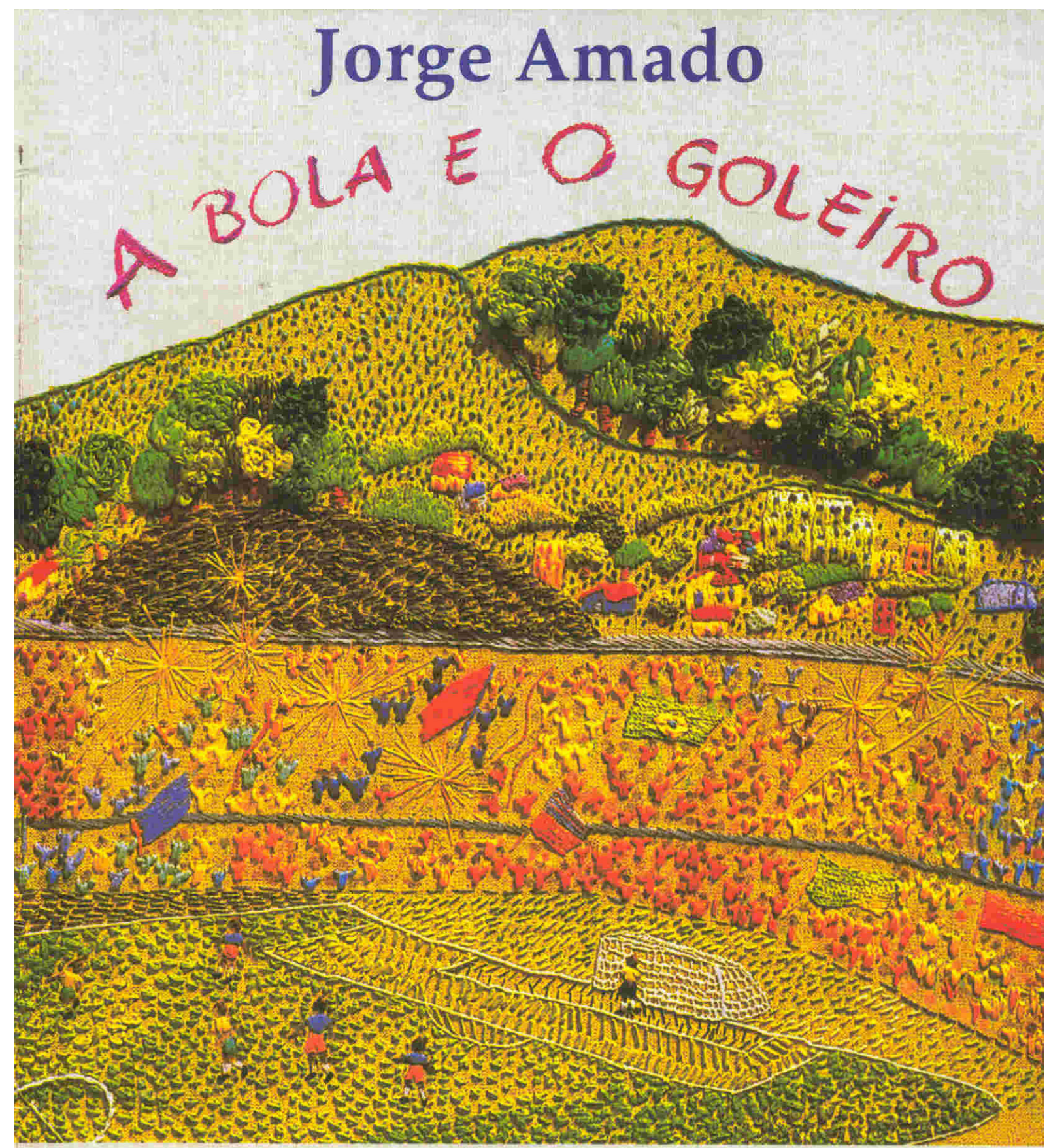

Bordados de Antônia Diniz Dumont, Ângela, Martha, Marilu e Sávia Dumont sobre desenhos de Demóstenes Vargas

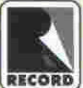




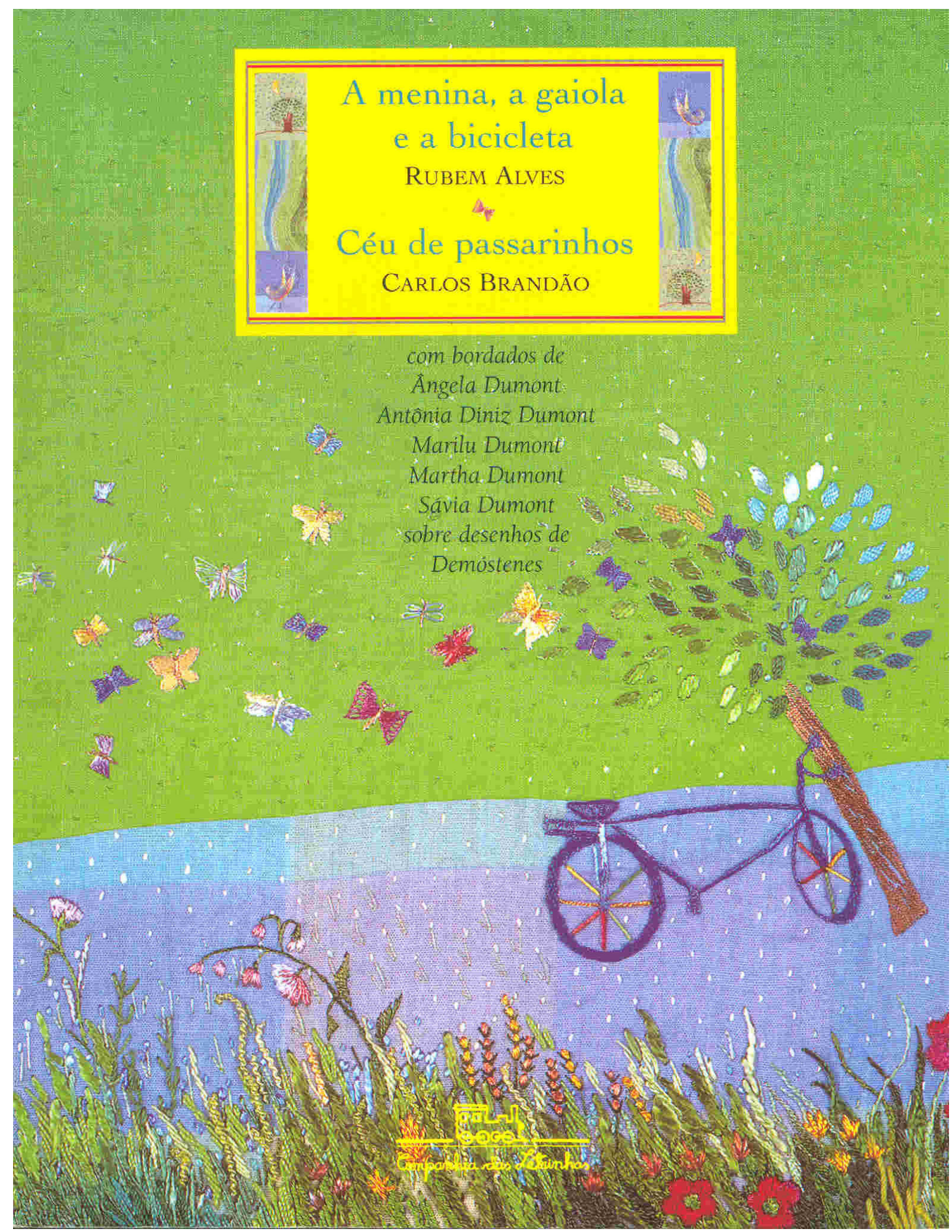

